UNIVERSIDADE DE SÃO PAULO

FACULDADE DE ECONOMIA, ADMINISTRAÇÃO E CONTABILIDADE DEPARTAMENTO DE ADMINISTRAÇÃO PROGRAMA DE PÓS-GRADUAÇÃO EM ADMINISTRAÇÃO

\title{
A FORMAÇÃO DOS PREÇOS DO ETANOL HIDRATADO NO MERCADO BRASILEIRO DE COMBUSTÍVEIS
}


Prof. Dr. João Grandino Rodas

Reitor da Universidade de São Paulo

Prof. Dr. Reinaldo Guerreiro

Diretor da Faculdade de Economia, Administração e Contabilidade

Prof. Dr. Adalberto Américo Fishmann

Chefe do Departamento de Administração

Prof. Dr. Lindolfo Galvão de Albuquerque

Coordenador do Programa de Pós-Graduação em Administração 


\title{
A FORMAÇÃO DOS PREÇOS DO ETANOL HIDRATADO NO MERCADO BRASILEIRO DE COMBUSTÍVEIS
}

\author{
Tese apresentada ao Departamento de \\ Administração da Faculdade de Economia, \\ Administração e Contabilidade da \\ Universidade de São Paulo como requisito \\ para obtenção do título de Doutor em \\ Administração.
}

Orientadora: Prof ${ }^{\mathrm{a}}$. Dr ${ }^{\mathrm{a}}$. Sonia Valle Walter Borges de Oliveira

SÃO PAULO 


\section{Lima, Nilton Cesar}

A formação dos preços do etanol hidratado no mercado brasileiro de combustíveis / Nilton Cesar Lima. -- São Paulo, 2011.

$218 \mathrm{p}$.

Tese (Doutorado) - Universidade de São Paulo, 2011.

Orientadora: Sonia Valle Walter Borges de Oliveira.

1. Etanol 2. Preços - Formação 3. Combustíveis 4. Biocombustíveis I. Universidade de São Paulo. Faculdade de Economia, Administração e Contabilidade II. Título. 
Dedico a toda minha família, por acreditarem que também somos capazes... 


\section{Agradecimentos}

Deus, muito obrigado por mais esse momento especial em minha vida!

À minha esposa Eloisa e ao meu filho João Haroldo, obrigado pelo amor, paciência incondicional e apoio, e me desculpem por esse meu "período de isolamento", amo muito vocês...

A meus pais, Nelson e Adelaide, pela simplicidade de vocês, pude entender que somos todos iguais nessa vida...

Aos meus irmãos, que me ensinaram o que é dividir e respeitar...

Ao Márcio Mattos e a Sônia, que souberam me acolher como um pai acolhe um filho, sinal de amor e muita sabedoria...

Ao Alceu e Alexandre Salgado, a quem agradeço pelas valiosas contribuições na banca de qualificação, dandome a oportunidade de ver mais longe...

Aos docentes da FEA, pelos ensinamentos...

Aos funcionários da secretaria da FEA/SP, obrigado! vocês são maravilhosos...

A Vera Mariza por servir à academia também partilhando sonhos...

A Andréa por ter aceitado o convite para participar como membro da banca examinadora...

Ao Márcio e ao Bruno da ANP, ao Dietmar da Sindicom, Bombig da Usina Alta Mogiana, pessoal da Orplana e Sincopetro, vocês foram valiosos para o resultado desse trabalho...

A todos do grupo Deus é Fiel, pelas orientações religiosas e necessárias para sempre alcançarmos o amor um pelo outro... 


\section{RESUMO}

O propósito do presente estudo é investigar a formação de preços do etanol hidratado no mercado de combustíveis do país. Esta pesquisa busca identificar como se forma o preço do etanol hidratado no mercado interno. A concepção teórica parte da compreensão da formação de preços abrangendo custos, economia de escala, fatores mercadológicos, econômicos e sociais na formação de preços. Em seguida, é realizada a contextualização do combustível etanol no mercado interno, como se caracteriza sua demanda e oferta, suas tecnologias e seus principais propulsores na difusão do mercado de combustíveis. Complementa-se com a caracterização do mercado internacional do combustível etanol e com os regulamentos ambientais existentes. Integrando-se as abordagens teóricas com a investigação realizada no setor de combustível etanol. O trabalho prossegue com a metodologia investigativa de atributos interno e externo para formar preços, o que motivou a escolha de uma metodologia baseada em estudos qualitativos e quantitativos, nos quais um complementa o outro em sua análise. Apresentando-se uma metodologia do tipo descritiva, exploratória e explicativa, a pesquisa proporciona reflexões e compreensão do mercado de etanol, que por meio de variáveis qualitativas preditivas, possibilita com o método quantitativo, explicar quais variáveis são significativas na formação dos preços praticados na revenda por meio do modelo de regressão linear múltiplo. Nesta etapa evidencia-se a contribuição em inferir quais variáveis explicam a formação de preços. De maneira secundária, a ferramenta estatística de Análise da Variância (Anova), possibilita identificar a vantagem do preço do etanol hidratado em relação à gasolina $\mathrm{C}$ no mercado interno. Pela regressão linear múltipla os resultados mostraram que os preços são formados significativamente pelos preços pagos ao produtor, distribuidora e custos de produção. Pela Anova, os resultados comprovaram também que a região Centro-Oeste foi a única que consolidou a vantagem do uso do etanol hidratado. Para ambos os resultados há reflexões explicativas que norteiam as razões e induzem predições acerca da formação de preços. Nesse sentido, uma reflexão estendida dos resultados permitiu analisar que a vantagem do uso do etanol hidratado na região Centro-Oeste, decorre das variáveis frota, bases de distribuição, tributos, produção e número de usinas produtoras. Com relação aos preços pagos ao produtor, distribuidora e custos de produção como principais variáveis explicativas na formação de preços, há evidências relativas por outras variáveis, que por mais que tenha sido apresentado coeficiente linear baixo, estes possuem relação causal, se complementados com a análise qualitativa, os quais, oferta, demanda, tributos e sazonalidade são, por exemplo, fatores que norteiam e dão complexidade à formação do preço.

Palavras-chave: Etanol, formação de preços, combustíveis e energia. 


\begin{abstract}
The purpose of the current study is to investigate the formation of the hydrated ethanol prices in the combustible market of the country. This research seeks to indentify how it is formed the price of the hydrated ethanol in the internal market. The theoretical conception comes from the comprehension of the prices formation involving costs, scale economy, market, economic and social factors in the price formation. Following, it is done the contextualization of the ethanol combustible in the internal market, as it is characterized its demand and offer, its technologies and its main propellers in the diffusion of the combustible market. It is complemented with the characterization of the international market of the ethanol combustible and with environment regulations existent. Integrating itself to the theoretical approach with the investigation done in the ethanol combustible sector. The work follows with the methodology investigated from internal and external attributes to the formation of the prices, what motivated the choice of a methodology based in qualifying and measurable studies, in which one complements the other in its analysis. Presenting a methodology of the descriptive, exploratory and explicative type, the research provides reflection and comprehension of the ethanol market, which by means of predictable qualitative variables, makes possible the quantitative method, explain which variable are significant in the formation of the prices practiced in the reselling by means of pattern of multiple linear regression. In this stage it is evidenced the contribution in inferring which variable explain the prices formation. In a secondary way, the statistic tool of Analysis of Variance (Anova), makes possible identify the advantage of the hydrated ethanol price in relation to the gasoline $\mathrm{C}$ in the internal market. By the multiple linear regression the results showed that the prices are formed significantly by the prices paid to the producer, distributor and production costs. By the Anova, the results prove also that the Center-West region was the only one that consolidated the advantage of the hydrated ethanol usage. For both the results there are explainable reflections that guide the reasons and induct predictions about the prices formation. In this way, an extended reflection of the results permitted to analyze that the advantage of the hydrated ethanol usage in the Center-West region, occurs from variable fleet, distribution basis, tributes, production and number of producer mill. In relation to the prices paid to the producer, distributor and production costs as main explainable variable in the prices formation, there are evidences related by other variables, which for more that have been presented low linear coefficient, there ones have casual relation, if complemented with the qualitative analysis, the ones which, offer, demand, tributes and seasonality are, as examples, factors that guide and give the complexity to the price formation.
\end{abstract}

Key-words: Ethanol, prices formation, combustible and energy. 


\section{SUMÁRIO}

1 INTRODUÇÃ̃O.................................................................................................................

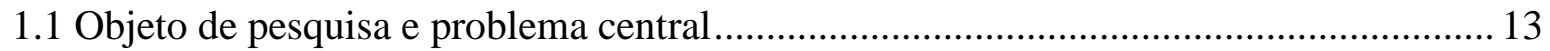

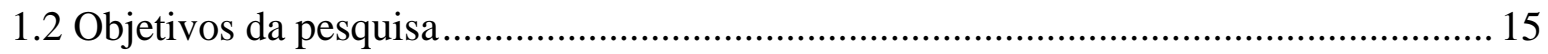

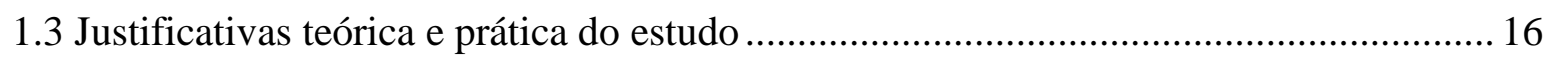

1.4 Contribuiç̧̃oes empíricas esperadas ....................................................................... 20

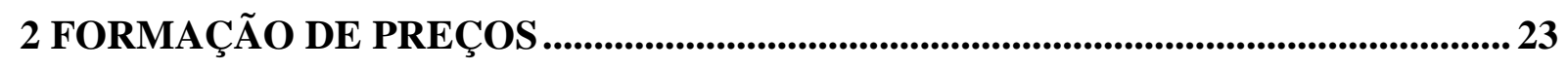

2.1 Abordagens conceituais da formação de preços e custos............................................. 24

2.2 Custos de distribuição e comercializaçãa.......................................................................29

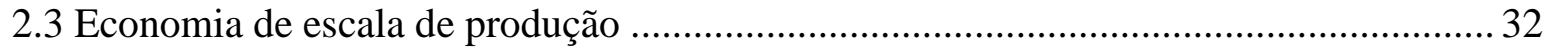

$2.4 \mathrm{O}$ elemento custos de produção na formação de preços................................................ 33

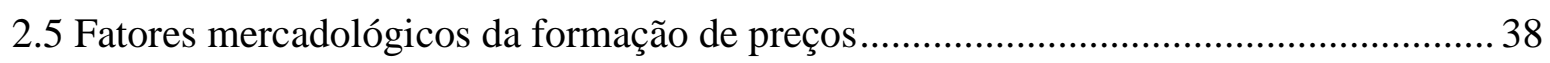

2.6 Abordagem econômica e social da formação de preços................................................. 45

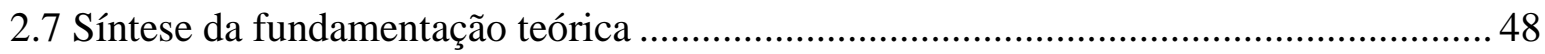

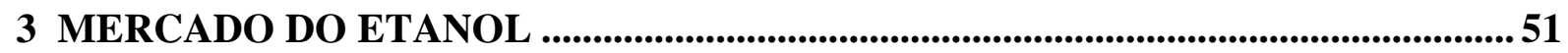

3.1 Caracterização da demanda do combustível etanol no Brasil ...................................... 51

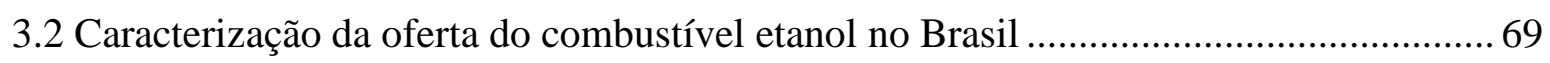

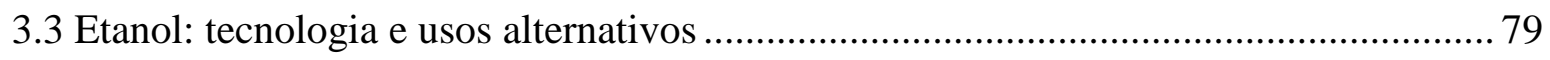

3.4 Flex Fuel: fusão dos mercados da gasolina $\mathrm{C}$ e etanol hidratado ............................... 90

3.5 Mercado internacional do combustível etanol ...........................................................96

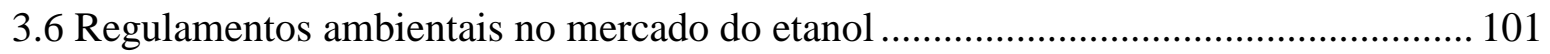

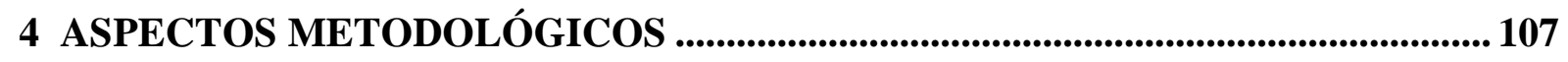

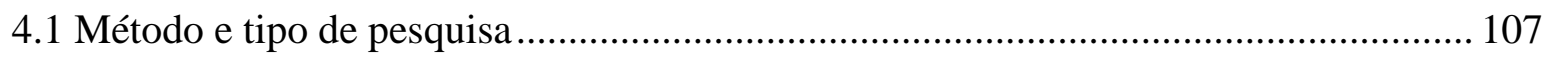

4.2 Esquema e característica de desenvolvimento da pesquisa........................................ 110

4.3 Procedimentos para coleta e análise de dados ........................................................... 113

4.4 Delineamentos das hipóteses e variáveis de pesquisa.................................................. 119 


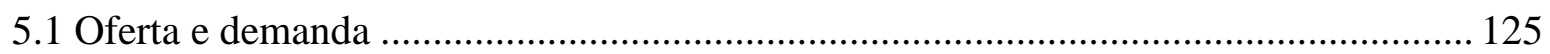

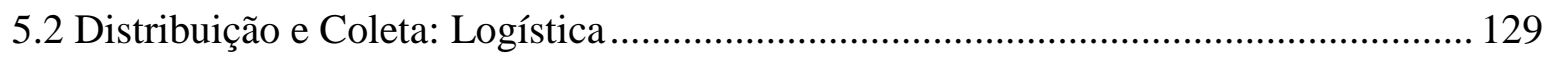

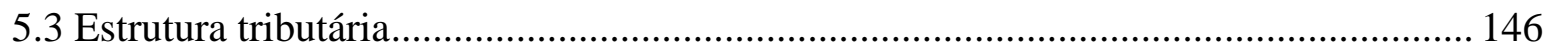

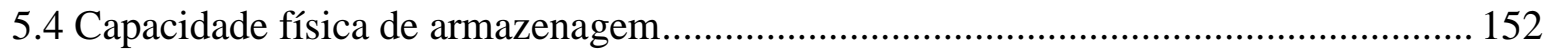

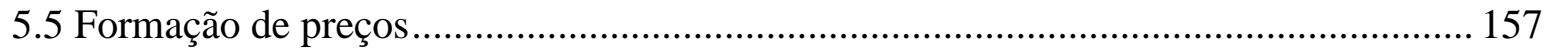

6 RESULTADOS, DISCUSSÃO E ANÁLISE DOS DADOS .................................... 177

6.1 Análise descritiva das variáveis para formação de preços ........................................ 180

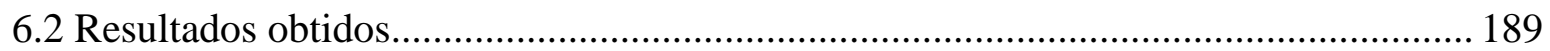

6.2.1 Discussão e análise dos dados obtidos: regressão linear múltipla ............................ 191

6.2.2 Discussão e análise dos dados obtidos: ANOVA com pós-teste de Tukey ............... 192

7 CONTRIBUIÇÕES, CONSIDERAÇÕES E CONCLUSÕES ........................................ 197

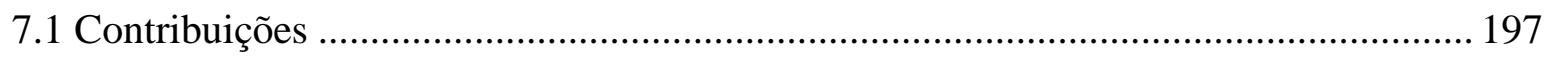

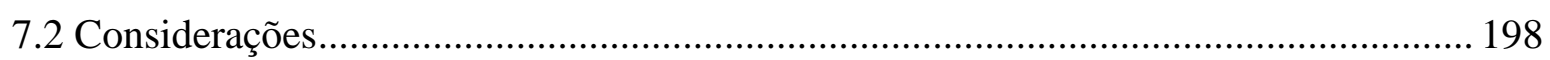

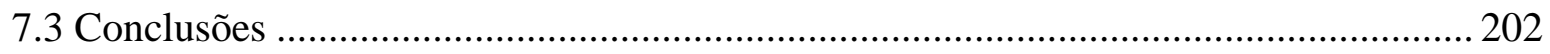

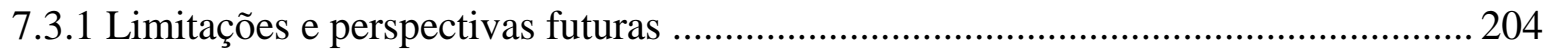

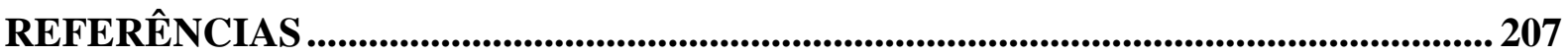




\section{LISTA DE TABELAS}

Tabela 1- Estimativa do Produto Interno Bruto do Setor Sucroenergético com base nos Produtos Finais (2008) 61

Tabela 2 - Venda de automóveis e veículos leves no Brasil (1979-2009) ..............................63

Tabela 3 - Perfil da frota (veículos leves) por tipo de combustível (2008 x 2017)..................65

Tabela 4 - Projetos para produção de resinas termoplásticas a partir de etanol ..................... 67

Tabela 5 - Produção de etanol hidratado de 2000 a 2009 (mil m3)....................................... 73

Tabela 6 - Valores de referência de oferta de etanol do MAPA (2006 x 2017) ....................... 78

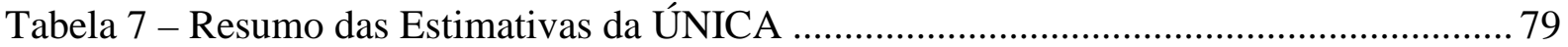

Tabela 8 - Variáveis explicativas da diferenciação dos preços do etanol hidratado .............. 121

Tabela 9 - Quantidade de postos revendedores de combustíveis automotivos por bandeira (2009) 141

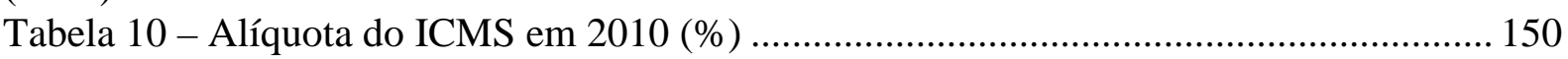

Tabela 11 - Quantidade de bases de distribuição de combustíveis líquidos derivados de petróleo e de etanol automotivo, segundo Grandes Regiões e Unidades da Federação, em $31 / 12 / 2009$ 155

Tabela 12 - Preço médio do etanol hidratado ao consumidor, segundo Grandes Regiões e

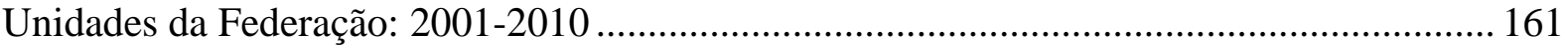

Tabela 13 - Preço médio da gasolina $\mathrm{C}$ ao consumidor, segundo Grandes Regiões e Unidades

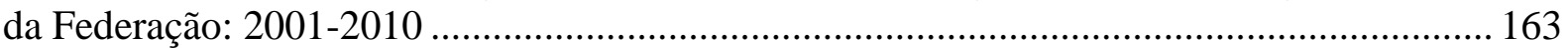

Tabela 14 - Composição de custos do litro de combustível nas distribuidoras do Estado de São

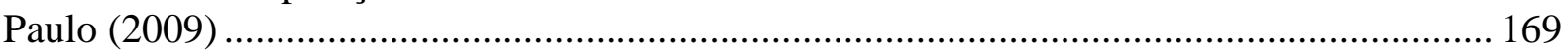

Tabela 15 - Decomposição do custo total de fabricação de etanol (2009) ............................. 174

Tabela 16 - Descrição das variáveis por Região (2009)........................................................ 181

Tabela 17 - Descrição da relação etanol/gasolina por região (2009) ….................................. 185

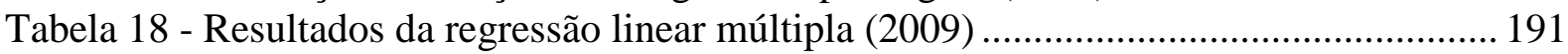

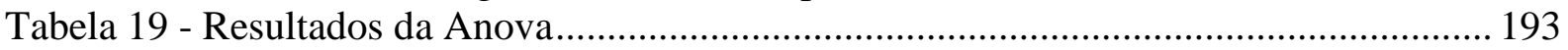

Tabela 20 - Médias estimadas para cada região, pelo modelo de Anova (2009) .................... 193

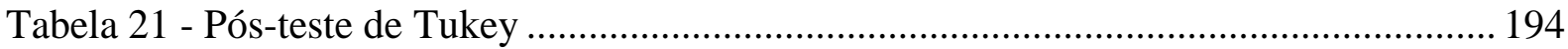




\section{LISTA DE GRÁFICOS}

Gráfico 1 - Participação percentual dos carros a etanol hidratado carburante e gasolina na

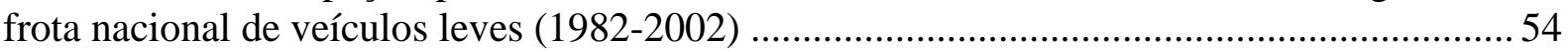

Gráfico 2 - Projeções de demanda total e da capacidade industrial de produção de etanol..... 66 Gráfico 3 - Distribuição percentual dos postos revendedores de combustíveis automotivos no Brasil, segundo a bandeira, em 31/12/2009 138 Gráfico 4 - Frota de autoveículos distribuídos em porcentagem por Unidade da Federação (2009) 140

Gráfico 5 - Relação entre os preços de gasolina e etanol no país: 2001 a 2010. 165

Gráfico 6 - Relação entre os preços de gasolina e etanol nas macrorregiões: 2001 a 2010 .. 165

Gráfico 7 - Preço de Revenda por região .... 185

Gráfico 8 - Relação (preço etanol/preço gasolina) por região 186

Gráficos 9A : $9 \mathrm{O}$ - Representações diversas da relação das variáveis versus preço de revenda 


\section{LISTA DE FIGURAS}

Figura 1- Formação de preços baseada no custo .............................................................. 25

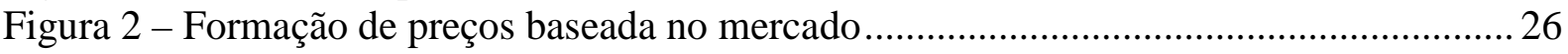

Figura 3 - Relações de comércio entre os agentes do setor sucroenergético na comercialização

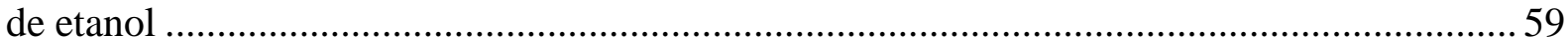

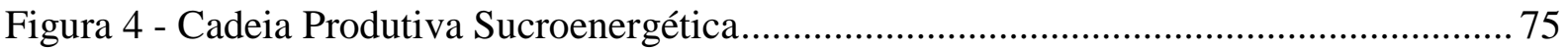

Figura 5 - Diagrama do fluxo da fabricação do etanol......................................................... 81

Figura 6 - Esquema síntese do processo de desenvolvimento da metodologia da pesquisa .111

Figura 7 - Relação entre os Objetivos e os Procedimentos Metodológicos ............................ 117

igura 8 - Localização das unidades produtoras de etanol ........................................................ 132

Figura 9 - Quantidade de postos revendedores de combustíveis por Unidade de Federação

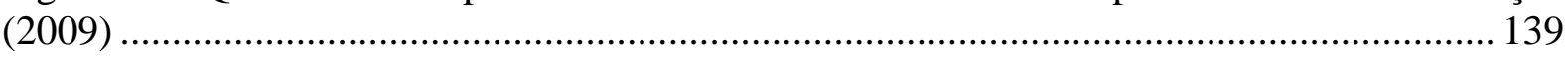

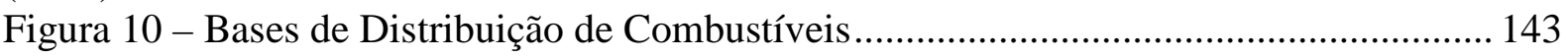

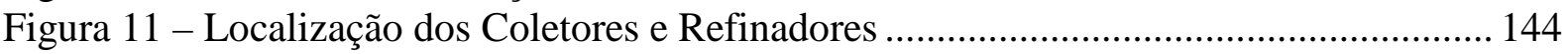

Figura 12 - Configuração da Rede de Distribuição do Etanol............................................... 145

Figura 13 - Relação entre os preços de gasolina e etanol por Estado..................................... 166 


\section{INTRODUÇÃO}

O presente estudo trata da formação de preços do etanol hidratado no mercado brasileiro. Este, por sua vez, consagra-se num segmento de combustíveis cuja escolha do consumidor final de abastecer com gasolina ou etanol é baseada apenas em preços, para aqueles que possuam veículos flex. É uma particularidade única no país cuja autonomia de decisão entre ter de abastecer com gasolina ou etanol é unilateral ao consumidor final. Isso demonstra que os setores de combustíveis, sucroenergético e o de veículos, têm apresentado nos últimos anos fortes mudanças tecnológicas, o que torna o ambiente competitivo. De forma complementar, no início de um novo século, XXI, tornou-se ainda mais evidente, dentre as diretrizes políticas e para a humanidade, a necessidade de redução das emissões de carbono e outros poluentes associados aos veículos, sobretudo nas grandes cidades e áreas metropolitanas.

Tal preocupação teve sua origem com a primeira crise do petróleo ocorrida em 1973, que levou a maioria dos países dependentes do petróleo importado da Organização dos Países Exportadores de Petróleo (OPEP) a se despertar para os graves problemas energéticos e econômicos. O efeito da crise gerou aumento dos preços do petróleo e um desequilíbrio na maior parte do comércio mundial, desencadeando depressão e inflação. Isso permitiu a busca de alternativas para reduzir a demanda de petróleo. Para reduzir esses efeitos econômicos adversos em vários países, muitos esforços foram feitos quanto ao desenvolvimento, consagrando-se, assim, a chamada "fonte de energia renovável".

Conforme a United Nations Conference on Trade and Development - Conferência das Nações Unidas sobre Comércio e Desenvolvimento (UNCTAD, 2003), as energias limpas/renováveis podem ser classificadas como bens ambientais, pois geram energia final a partir de fontes renováveis e/ou emitem menor quantidade de substâncias como dióxido de carbono, monóxido de carbono e dióxido de enxofre, entre outras, na atmosfera. Essas novas fontes renováveis incluem a biomassa moderna: pequenas hidrelétricas, energia geotérmica, eólica, energia solar, marinha e as usinas sucroenergéticas responsáveis pela produção do combustível etanol. Dessa forma, a biomassa moderna já não considera somente os usos tradicionais, como a lenha; há, portanto, novas alternativas dadas por meio da geração de eletricidade e de combustíveis líquidos para transporte, provenientes, por exemplo, da canade-açúcar e do milho. 
Cerca de $80 \%$ de toda a energia utilizada no mundo provêm de combustíveis fósseis, que são os principais poluentes do meio ambiente e os responsáveis por problemas de saúde em nível local, regional e global. Os outros 9,5\% vêm da biomassa tradicional, e os demais 10,5\% provêm da energia nuclear, carvão mineral, eólica, solar, geotérmica e outros (IEA, 2001).

Nos estudos desenvolvidos pela Comissão Europeia (2004), registrou-se que a utilização de energias renováveis, particularmente as de origem na biomassa, apresenta as seguintes vantagens: redução das emissões de gases de efeito estufa, aumento da oferta de energia, produção de energia sustentável no longo prazo, criação de oportunidades de emprego, desenvolvimento econômico localizado e redução das importações de combustíveis convencionais. Tais vantagens provocaram a expansão do uso das energias renováveis, principalmente no que se refere à produção de biocombustíveis. Se por um lado alguns países dirigiram suas políticas macroeconômicas para atingir o equilíbrio fiscal, ambiental, comercial e, sobretudo, evitar que se desencadeasse uma inflação da demanda por conta das elevações dos preços do barril de petróleo, sobretudo com a crise de 1973; por outro lado, no Brasil, os efeitos da crise do petróleo nas décadas de 1970 e 1980 motivaram a busca por alternativas tecnológicas, promovidas pelo setor sucroenergético e automobilístico, que reconhecesse o uso de um combustível alternativo viável e substituto à gasolina.

Nesse sentido, algumas ações estratégicas foram iniciadas por meio de investimentos em exploração e produção de petróleo. A ação significativa para o presente estudo foi o programa Proálcool, com dois segmentos principais: o primeiro segmento foi o desenvolvimento de etanol, da cana-de-açúcar, como combustível para automóveis; o segundo foi o desenvolvimento de motores de automóveis que seriam movidos $100 \%$ por etanol e, posteriormente, por meio dos motores flex.

O Programa Nacional do Álcool (Proálcool) motivou variados esforços tecnológicos na cadeia produtiva do etanol. Foi consagrado como o maior programa de energia renovável já estabelecido em termos mundiais, em que a atuação governamental brasileira no setor sucroenergético viveu pelo menos dois momentos distintos. O primeiro momento ocorreu após a crise dos preços do petróleo em 1973, que culminou na criação do Proálcool, a qual se deu em duas etapas: a primeira etapa tinha o propósito de produzir etanol anidro, que seria misturado na gasolina, ao passo que a segunda etapa tinha o propósito de produzir etanol 
hidratado, para o uso em veículos movidos exclusivamente a etanol. Já o segundo momento compreende o desenvolvimento de tecnologias aplicáveis a um tipo de motorização exclusiva ao uso do combustível etanol hidratado que posteriormente contribuiu para o surgimento da tecnologia flex, bem como o desenvolvimento de infraestrutura de distribuição que passou a cobrir todo o país.

Desse modo, a constatação a ser observada ao longo deste estudo é que o referido programa, desativado no final dos anos de 1980 devido a dificuldades econômicas e pela baixa do preço do petróleo internacional, promoveu esforços tecnológicos não só na cadeia produtiva sucroenergética, como também nos avanços alcançados na indústria automobilística. Esses avanços tecnológicos na indústria automobilística trouxeram, por sua vez, a autonomia ao consumidor final, que pôde optar por qual combustível utilizar, tendo como referência de decisão o preço. Em outras palavras, o entorno que motivava o uso do combustível etanol estava sob um cenário contundente dos preços do petróleo e das alternativas tecnológicas trazidas pelo setor sucroenergético e acompanhadas pelo automobilístico. E, após a inserção da tecnologia flex, os preços passaram a ser objeto de decisão no abastecimento pelo consumidor final, sinalizando uma necessidade de compreender a formação dos preços no mercado interno e suas respectivas vantagens no abastecimento no posto de revenda.

Observa-se que o fato de o Brasil já ter uma experiência de consumo e uma infraestrutura implantada de distribuição de etanol e gasolina em todo o território nacional, desde meados da década de 1970, permitiu uma adoção imediata dos consumidores, fazendo que, em 2009, mais de $90 \%$ dos veículos novos vendidos fossem flex fuel - segundo Anfavea (2010a). No entanto, os aspectos decisórios no abastecimento precisam ser mais bem compreendidos se, dentre as diferenças de preços no mercado interno, ainda se imprime o uso do combustível gasolina C como vantagem ao consumidor final. Sendo assim, a tecnologia no setor sucroenergético, incentivada inicialmente pelo Proálcool, sob seus diversos segmentos, vem apontando avanços juntamente com as indústrias automobilísticas. Cabe entender, nesse sentido, se tal avanço se compatibiliza quanto à prática dos preços no mercado nacional. Embora a tecnologia flex evidencie o cenário de que o etanol é a tecnologia de combustível viável empregada atualmente no mercado interno como alternativa ao uso da gasolina, os preços não são majorados no mercado interno de maneira uniforme. Entende-se, portanto, que os esforços foram notórios no desenvolvimento de tecnologia acerca do combustível etanol, 
mas ainda estão defasados com relação à prática dos preços no mercado interno, uma vez que as diferenças regionais de preços exprimem a necessidade de compreendê-los por meio do presente estudo.

Neste estudo, será possível observar que a indústria automobilística cumpriu com seu papel ao longo das últimas décadas, avançando sua tecnologia no desenvolvimento de veículos flex fuel. Isso foi possível graças ao reordenamento na cadeia produtiva do etanol constituída durante a fase do Proálcool, com relação aos aspectos regulatórios, fiscais e estruturais, os quais foram relevantes na consolidação do atual mercado do combustível etanol no país. Ou seja, o que cabe investigar neste estudo são a existência e a formação que dão as razões das diferenças dos preços do etanol hidratado praticados no mercado interno, já que os esforços tecnológicos têm cumprido seu papel. Esses outros esforços não cessam no setor energético, que, por sua vez, persiste nos desafios da engenharia quanto aos motores híbridos, bem como quanto ao uso de hidrogênio, gás natural, etanol e outros combustíveis, servindo, também, como fontes de estudos de diversas áreas, em que convergem interesses em meio ambiente e economia de escala no objetivo de sanar sua viabilidade.

Um dado interessante é que todos os esforços ao entorno da indústria automobilística, ao longo das últimas décadas, têm despertado grandes discussões nas mais diversas áreas do conhecimento, proporcionais ao seu tamanho: ela está presente em quase todos os continentes, emprega, no mundo, mais de 60 milhões de pessoas direta e indiretamente, e cresceu $30 \%$ na última década (OICA, 2008). Esses números permitem confirmar sua absoluta influência econômica e social no planeta. Em contrapartida, apesar de atender a uma função estimada pelo homem moderno (a liberdade de locomoção), esse setor é responsável direto por $16 \%$ de $\mathrm{CO}_{2}$ emitidos na atmosfera, além de interferir no dia a dia das pessoas, seja no tráfego urbano, seja nas áreas rurais para plantio, seja no meio ambiente. No caso do etanol hidratado em seu uso por meio do motor flex, o parâmetro decisório não é só ambiental, mas também econômico, no instante em que o preço se torna a variável decisória no abastecimento.

As discussões acerca de combustíveis remetem, neste presente estudo, à compreensão de que as alternativas tecnológicas surgem para sanar efeitos não só ambientais e sociais, mas também econômicos, no que se refere à prática dos preços dos combustíveis no mercado brasileiro, especificamente do etanol hidratado. As vantagens das novas fontes de energia 
renováveis realçam a diversidade nos mercados de fornecimento de energia, uma vez que reduzem as emissões atmosféricas (local, regional e global), geram novos empregos e oferecem oportunidades de desenvolvimento em comunidades rurais e possibilidades de produção local, aumentando, assim, a segurança do abastecimento interno.

Assim, cabe compreender a formação dos preços do combustível etanol hidratado e, por conseguinte, apontar algumas explicações das diferentes práticas na dimensão do mercado interno. Isso porque, se a frota de carros de passeio é flex, o consumo do etanol, ecologicamente melhor, depende de preço vantajoso em relação à gasolina, consagrando-se, portanto, a famosa relação de até $70 \%$ do preço do etanol por litro em relação ao preço da gasolina C. Dessa forma, será possível constatar que a busca por novos combustíveis para transporte está dando lugar ao desenvolvimento de novos paradigmas em termos de comercialização, regulação e, sobretudo, de inovações tecnológicas. Para isso, as indústrias automobilísticas desafiam-se constantemente, tendo de oferecer um veículo com combustível alternativo e econômico aos seus consumidores, desde que os preços sejam competitivos e promovam efeitos mercadológicos adversos na prática.

No entanto, é preciso destacar brevemente, neste estudo, a importância da tecnologia flex fuel - Flexible Fuel Vehicles (FFVs) -, isto é, usada em automóveis ou utilitários leves que operam com gasolina, etanol hidratado ou quaisquer misturas desses combustíveis; essa tecnologia dá uma autonomia no abastecimento, tendo como parâmetro o preço no posto de revenda. Além disso, essa tecnologia evidencia que a decisão sobre qual combustível utilizar é feita pelo usuário no momento do abastecimento; logo, a principal variável que determina a demanda é o preço do combustível. Ou seja, este estudo investiga se a competitividade como fruto dos investimentos tecnológicos pode ser espelhada no mercado interno do combustível etanol hidratado via disparidade regional dos preços.

O Brasil apresentou localmente uma tecnologia capaz de responder às necessidades sustentáveis - a do bicombustível ou flex, preenchendo parte da cadeia produtiva no setor sucroenergético. Nesse aspecto, a presente pesquisa contribui como estímulo a estudos futuros acerca do desenvolvimento de energias sustentáveis, baixo teor de carbono, cujos avanços tecnológicos possam se associar a interesses ambientais e econômicos no que compete à acessibilidade ao consumo no mercado interno com preços realmente competitivos. 
Neste estudo, será possível notar que, além da tecnologia que se desenvolve acerca do combustível etanol, desencadeiam-se, também, as necessidades por novas frentes de amadurecimento quanto à acessibilidade e à vantagem no uso do etanol hidratado. Ou seja, pretende-se avaliar, nesta tese, se há confluência de fatores relacionados à formação dos preços capaz de inviabilizar seu uso no mercado por características econômicas, quando se trata de tributos, fretes, armazenamento e usos alternativos da matéria-prima cana-de-açúcar. Em outras palavras, a diferença dos preços no mercado brasileiro do combustível etanol hidratado mediante os avanços tecnológicos e fatores que se relacionam à sua formação de preços previamente apontados sinaliza alvos de investigação para saber se a coordenação da cadeia em sua intensidade tecnológica foi similar aos preços praticados no mercado do etanol e em quais fatores reside a diferenciação dos preços desse combustível, de modo a pautar sua viabilidade e eficácia mercadológica nas mais variadas regiões do país.

Assim, atenuar o ponto de inovações tecnológicas existentes no setor do etanol replica ao questionamento de saber se forças competitivas ditam sua precificação no mercado interno de maneira acessível e vantajosa nas variadas regiões do país, dado que os desenvolvimentos das indústrias produtoras e das empresas do setor automobilístico buscam oportunizar o consumidor final sob a decisão de abastecer com etanol hidratado ou com gasolina $\mathrm{C}$, tendo como referência decisória o preço obtido no posto de revenda. Portanto, faz-se necessário investigar a formação de preços do combustível etanol hidratado no mercado brasileiro.

O ordenamento tecnológico proporcionado ao setor somado aos interesses comerciais, produtivos, ambientais, fiscais e de distribuição levanta a hipótese de que os preços praticados são majorados sob essas situações, cabendo, neste estudo, investigar seus reais mecanismos de formação e suas respectivas vantagens comparativas no mercado interno. Uma constatação prévia é que as mudanças tecnológicas promovidas pelo flex já caracterizam uma decisão econômica na hora de ter de decidir por qual combustível consumir, e esse fato motiva a investigação sobre como se compõem os preços do etanol hidratado e suas possíveis explicações quanto às disparidades no mercado interno. Sob essa dimensão de estudo, as observações exploradas na literatura estarão relacionadas à teoria da formação de preços, no que compete a custos e equilíbrio de mercado (oferta e demanda), retratando, posteriormente, uma trajetória de causas e limitações sobre a composição dos preços do etanol hidratado ao estudar seu respectivo mercado. 
Portanto, este estudo tem o propósito de apresentar a formação do preço do etanol hidratado no mercado interno, no sentido de compreender suas vantagens nas mais variadas regiões do país. Para colaborar com essa discussão, este trabalho conta com o aporte teórico acerca da formação de preços, custos e mercados no que compete à contextualização da oferta e da demanda por etanol, tecnologias alternativas, mercados internacionais e regulamentos ambientais. Com isso, tem-se o objetivo de identificar a composição dos preços e compreender os respectivos mecanismos diferenciadores nas mais variadas regiões geográficas do país, de modo que a investigação da formação de preços se consolida na sua ordem econômica no mercado interno em promover a decisão entre optar pelo combustível etanol hidratado ou pela gasolina $\mathrm{C}$.

\subsection{Objeto de pesquisa e problema central}

O objeto e o problema a ser enfrentado por esta tese contextualizam-se na formação do preço do combustível etanol hidratado no mercado interno, praticado no posto de revenda.

Quando um indivíduo adquire um veículo que lhe permite abastecer com dois tipos de combustíveis líquidos (etanol hidratado e/ou gasolina $\mathrm{C}$ ), chamados automóveis "flex", ele passa a ser o decisor quanto ao melhor preço entre etanol hidratado e gasolina $\mathrm{C}$ em qualquer posto de abastecimento. A decisão é feita exclusivamente em termos de preços e considerações de eficiência. Da mesma forma, os produtores reagem aos preços de equilíbrio de petróleo e matérias-primas, o que resulta na atual dinâmica na ponta energética do combustível etanol.

Os setores sucroenergético e o de combustíveis constituem-se como parte fundamental da matriz energética do país, e o presente estudo busca investigar o etanol hidratado, proveniente do setor sucroenergético, quanto à formação dos preços nos postos de revenda praticados nas variadas regiões do país, uma vez que a tecnologia empregada em todo o setor e as regulamentações ambientais se propagam como uma tendência no mercado atual. Para tanto, será adotada, por exemplo, como fator ou variável de expressividade para o estudo, a estrutura logística, sobretudo a de distribuição, a fim de compreender a dinâmica de preços ligada a partir da difusão do uso do veículo bicombustível. 
Como objeto de investigação para o presente estudo, tem-se: a formação de preços do etanol hidratado no mercado brasileiro. A partir disso, adotaram-se como campo a ser inicialmente percorrido os componentes de custos que caracterizam a oferta e, posteriormente, a contextualização do mercado e dos respectivos limites quanto aos usos alternativos propiciados pela cana e pelo etanol, que perfazem o entendimento da demanda, admitindo que essa demanda já esteja motivada após o emprego da tecnologia flex, por proporcionar autonomia decisória no abastecimento, prevalecendo o consumo do etanol desde que seu preço esteja abaixo de $70 \%$ em relação à gasolina $\mathrm{C}$.

Nesse sentido, a evidenciação de pesquisa quanto à intensificação energética no mercado de combustíveis a ser observada está relacionada ao mercado de etanol hidratado, competindo à investigação da formação dos preços existentes. Os elementos que consistem na análise da investigação se atentam à estrutura tecnológica em toda a cadeia produtiva, às desregulamentações dos preços, às normatizações ambientais e, sobretudo, ao uso da tecnologia flex fuel que viabiliza, embora não justifiquem, a dispersão dos preços relativos no mercado nacional.

Como problema central para investigação do presente estudo, adotou-se: como se forma o preço do etanol hidratado no mercado interno? Ao solucionar esse problema de investigação, será possível compreender as variáveis que consistem nas diferenças do etanol hidratado no mercado interno, que, por sua vez, contribui para a prática de preços na revenda, posto de combustível. A outra metade do problema (ou seja, como se forma o preço da gasolina C) não será estudada aqui. Obviamente, o preço do etanol depende de fatores técnicos, de mercado e institucionais, cada um dos quais pode sofrer mudanças favoráveis ou desfavoráveis ao uso do etanol como combustível (daí o interesse pela questão), seja para apoiar o consumo do etanol hidratado, seja para combatê-lo em momentos em que o preço estiver alto em relação à gasolina.

A pergunta de pesquisa surgiu em função da inter-relação existente entre a formação de preços do etanol e as práticas de preços do combustível etanol para o consumidor final diante da estrutura existente no mercado de combustíveis, proporcionada pela cadeia produtiva sucroenergética e por empresas do setor automobilístico como condição exigida ou cenário já consolidado capaz de sustentar resultados positivos aos olhos tecnológicos, mas insuficientes 
no processo de reordenamento do setor, quando se trata da formação dos preços praticados aos consumidores finais.

E, como complemento da investigação neste estudo, será possível inferir as variáveis que promovem as diferenças dos preços do combustível etanol nas macrorregiões do país, ao investigar os componentes da formação de preços e o mercado do etanol, lançando-se, por conseguinte, a questão paralela ao problema central: quais as vantagens comparativas entre etanol hidratado e gasolina $\mathrm{C}$ no mercado interno?

Para responder ao problema central e a essa pergunta de pesquisa, parte-se da visão de que os consumidores finais são decisores sobre o tipo de combustível que vão utilizar. Por sua vez, os principais propulsores da energia alternativa, quando da posse do veículo bicombustível, fazem a pergunta tradicional: quanto custa ou qual é o preço? Essa ótica permite uma premissa básica de investigação ao considerar a hipótese de que a difusão tecnológica do veículo bicombustível e da cadeia produtiva do etanol, acrescida da desregulamentação do setor, tenha servido de atributo à dinamização dos preços do etanol praticados ao consumidor final.

\subsection{Objetivos da pesquisa}

Richardson et al (1999) definem a expressão "objetivo geral de pesquisa" como sendo "o que se pretende alcançar com a realização da pesquisa". O autor ainda comenta que o objetivo geral de uma pesquisa "deriva diretamente do problema de pesquisa" a que se pretende responder. Em outras palavras, o objetivo geral do estudo é responder ao problema de pesquisa levantado.

Considerando que a tecnologia do etanol ao longo de sua cadeia produtiva já se consolida tanto quanto o seu desenvolvimento, processamento ou ao uso com a tecnologia flex fuel, permite-se constatar que o objetivo geral deste estudo é: analisar a formação de preços do combustível etanol hidratado no mercado brasileiro. Isso permitirá alçar como objetivo secundário investigar qual combustível é vantajoso dentre as diferentes práticas de preços nas macrorregiões do mercado interno. 
Dessa maneira, a temática deste estudo reforça a compreensão do mercado do etanol a partir da base de formação de preços tomados pelos custos e limites impostos pelos usos alternativos. Estes servirão de cenários para compreender o dinamismo na precificação do etanol, bem como que variáveis implicam a diferenciação regional dos preços praticados no mercado brasileiro.

Com o propósito de observar a formação dos preços do etanol, estenderam-se como objetivos específicos os seguintes:

1- Analisar a formação de preços do combustível etanol hidratado no mercado brasileiro;

2- Identificar as principais variáveis que determinam os preços do etanol ao consumidor final;

3- Identificar qual região é mais vantajosa no abastecimento por etanol hidratado em relação à gasolina $\mathrm{C}$.

\subsection{Justificativas teórica e prática do estudo}

Partindo-se do objeto de estudo, qual seja, os preços do etanol hidratado, este, sem dúvida, vem sendo um campo de investigação de interesse de inúmeros pesquisadores. O desafio intelectual sobre o tema "formação de preços do etanol hidratado no mercado brasileiro" ainda está lançado e passível de maior exploração, dado que o mercado é complexo e dinâmico. Pela natureza verificada nos estudos teóricos preliminares sobre formação de preços, percebe-se que há um campo complexo que cerca não só aspectos quantitativos, mas também qualitativos, os quais têm sua dinamicidade por relacionar-se com os comportamentos de mercado.

Como justificativa teórica para o presente estudo, é importante destacar os seguintes aspectos: as pesquisas sobre composição dos custos na produção de etanol hidratado, as limitações no uso propiciado tanto pela cana-de-açúcar como pelo etanol, como também pela herança tecnológica auferida pelo flex, e os condicionantes mercadológicos constituídos pelo Proálcool que demarcaram a disponibilidade do produto no mercado interno. 
Há que se considerar que a atividade de distribuição de combustíveis automotivos no país envolveu, em 2009, 421 usinas de etanol, 198 empresas distribuidoras, operando 425 bases de distribuição, 5.188 pontos de abastecimento e fornecendo produtos a 36.730 postos revendedores (ANP, 2010). Essas constatações relacionadas ao tamanho do setor produtivo e seus respectivos canais de distribuição se confirmam nos estudos de Durães (2008), em que o autor afirma que, por meio de dados estatísticos comparativos sobre os recursos naturais, ganhos em inovação e análise de experiências no setor sucroenergético e na agroindústria tropical, se coloca o Brasil - em relação a muitos países de clima tropical e temperado - em condições vantajosas na produção e distribuição de biocombustíveis.

O etanol e a tecnologia flex fuel combinam-se como a melhor alternativa encontrada no mercado até o momento e de aderência a esses canais de distribuição, facilitando a autonomia decisória ao consumidor final sobre o preço mais conveniente na hora de abastecer seu veículo, seja pelo tipo de combustível a abastecer, seja pela revenda que melhor lhe convém.

Com base numa proposição teórica constituída por este estudo, entende-se que o setor energético do país, representado pelo etanol, apresenta um avanço tecnológico em toda a sua cadeia produtiva, que, por sua vez, permite ao consumidor final, ao abastecer, a autonomia de escolher entre o etanol e a gasolina, caracterizando uma primeira hipótese de que as forças de mercado entre oferta e demanda determinariam os preços e influenciariam na decisão do consumidor.

Sob o aspecto de distribuição do etanol, reforçam-se algumas considerações que norteiam novas fronteiras teóricas a partir desse estudo: aumento na capacidade produtiva do etanol, ampliação e reestruturação das distribuidoras e dos postos de combustíveis, reordenamento fiscal entre os Estados, constituição de estoques reguladores, fusões e aquisições de indústrias sucroenergéticas, regulações e normatizações no consumo e mistura do etanol, políticas públicas à matriz energética e aos órgãos de pesquisas desenvolvedores de componentes e sistemas voltados para a diversidade do uso do etanol em outros motores e combustíveis etc.

Em relação à diversidade no uso do etanol, destaca-se, por exemplo, a intensificação tecnológica do eteno verde (hidrocarboneto constituído por dois átomos de carbono e quatro de hidrogênio, muito utilizado em indústrias como matéria-prima do plástico em seu processo 
de produção a partir do etanol). Ou seja, o mercado de combustíveis depara-se com uma diversidade de possibilidades de usos a partir do etanol, a qual, por sua vez, tem relação com a oferta no mercado energético de combustível veicular.

Ademais, a relevância deste estudo justifica-se pela crescente demanda por energia no país. Essa demanda de energia (combustível) apresenta sinais de crescimento, registrados conforme a ANP (2010): 9,7\% de elevação de todo o combustível consumido no país no primeiro semestre de 2009 em relação a 2008, correspondente a 51,03 bilhões de litros. E o etanol apresenta-se eficiente ao mercado de combustíveis alternativos em suas projeções futuras devido à sua segurança energética em produtividades (uma vez que a cadeia produtiva está amparada tecnologicamente para avançar nesse segmento) e à redução de poluentes de origem veicular.

Por outro lado, Romm (2006) considera que o veículo do futuro será o híbrido, gasolinaelétrico, porque pode reduzir o consumo de gasolina e as emissões de gases com efeito de 30$50 \%$, sem mudança de classe de veículo. Essa plataforma pode se tornar a dominante do veículo até o ano de 2020, sobretudo se, nesse composto híbrido, houver, também, a presença do etanol. Entretanto, sua inferioridade econômica atualmente não viabiliza seu uso. Ainda para o autor, tais desafios de engenharia e argumento alternativo em relação ao uso do etanol ou gasolina existem devido ao esforço da política ambiental no setor de transporte, uma vez que cerca de $97 \%$ de toda a energia consumida entre veículos, utilitários esportivos, vans, caminhões e aviões ainda é feita à base de petróleo.

É oportuno destacar que o hidrogênio se apresenta como o maior desafio de todos os combustíveis alternativos, especialmente em razão do grande esforço tecnológico necessário e pela própria infraestrutura já consolidada pela gasolina existente. Tal tendência concretiza o desafio não de reduzir o consumo de petróleo, mas, sim, de como atender a uma crescente demanda por combustíveis não poluentes e a preços homogêneos no mercado nacional. Em outras palavras, a perspectiva não deve ser simplesmente um ponto de vista míope a isolar apenas o desenvolvimento de uma determinada tecnologia, como o flex fuel, mas observar aspectos do desenvolvimento do veículo bicombustível, ou outro, ao patamar estrutural sobre a forma de fornecer combustível suficiente e a preços esperados e homogêneos no mercado interno. Isso permite um diálogo com a teoria trazida por Gallagher et al (2006) sob inovações 
tecnológicas em energia, segundo a qual o conjunto de processos que conduzem a novas tecnologias energéticas capazes de aumentar os recursos energéticos melhora a qualidade dos serviços de energia e reduz os custos econômicos, ambientais ou políticos associados ao fornecimento e à utilização de energia. Nas considerações conceituais acerca de inovações tecnológicas em energia, o referido autor afirma tratar-se de um conjunto de processos que conduzem as tecnologias de energias novas ou melhores que possam aumentar os recursos energéticos e a qualidade dos serviços de energia, bem como reduzir o impacto econômico, ambiental ou político cujos custos estejam associados ao fornecimento e à utilização de energia, podendo, também, reduzir a dependência do petróleo, favorecendo, assim, o clima global. Para o pesquisador, a promoção de inovações tecnológicas no setor energético deve-se à integração da cadeia e das políticas públicas direcionadas; tal processo de inovação é tipicamente incremental, cumulativo e assimilado entre os elos do setor.

Foi com base nesses aspectos que o presente estudo tomou como embasamento teórico de pesquisa a formação de preços acerca de custos e equilíbrio, contextualizando a oferta e a demanda por meio da investigação do mercado, ambas abordadas no Capítulo 2 e 3 respectivamente. Partindo daqui, constituiu-se o entendimento prático deste estudo: estudar a formação dos preços do etanol hidratado no mercado interno.

Estudar preços é pertinente porque, após o advento do veículo flex fuel, colocou-se para o consumidor final uma decisão de compra baseada apenas no preço: vale a pena abastecer com o etanol hidratado se este custar abaixo de $70 \%$ da gasolina, admitindo esse percentual como índice relativo entre preço do etanol hidratado versus preço da gasolina C. Isso permite direcionar como foco investigativo empírico para este estudo a formação dos preços praticados no mercado de combustíveis. Tudo isso conduz a uma importante questão: de que adianta ter normatizações, desregulamentações e avanços tecnológicos na cadeia produtiva se a prática dos preços não for equivalente entre as diversas localidades do mercado de combustível, que conduza à viabilidade econômica para o consumidor final e aos objetivos também ambientais?

Portanto, esta contribuição acadêmica se sustenta na justificativa de que há pouca bibliografia que envolve a formação dos preços do etanol hidratado e sua respectiva vantagem entre optar pelo etanol hidratado ou gasolina $\mathrm{C}$, dada as diferentes práticas ao consumidor final no 
mercado brasileiro. Boa parte do que está disponível é um vasto estudo a respeito da cadeia produtiva do combustível etanol no que compete aos ganhos tecnológicos.

\subsection{Contribuições empíricas esperadas}

Neste estudo, parte-se do pressuposto de que o Brasil é um polo de desenvolvimento tecnológico no processo produtivo do etanol, por meio da cana-de-açúcar, e no setor automobilístico, pelo sistema flex fuel, que permite a utilização da mistura, ou não, do etanol como combustível veicular em motor à gasolina. $\mathrm{O}$ que se tem até o momento é o uso do etanol como uma das alternativas no mercado de combustível, graças ao motor flex fuel, não havendo produção em escala e, comercialmente, qualquer outro veículo que não seja o flex.

E o que se configura no mercado de combustíveis é uma coordenação existente no fornecimento do combustível etanol, que demanda custos e possibilita usos alternativos, seja a partir da cana, seja a partir do etanol, e que pode servir de análise comparativa na eficácia da comercialização no mercado brasileiro no sentido de avaliar se a cadeia produtiva do etanol se apresenta plenamente coordenada no momento de disponibilizar etanol hidratado ao consumidor final, de tal modo que este não se sensibilize pela alta volatilidade dos preços praticados no posto de revenda.

Com relação ao aspecto "disponibilidade do etanol hidratado no mercado de revenda", não há entraves ou falta de coordenação, dado que os postos de combustíveis já possuíam a estrutura necessária para ofertar o produto. Porém, é preciso saber como se explicam a formação de preços do etanol, tendo em vista que, em estrutura de fornecimento no posto de revenda do combustível, o produto não é limitado. Cabe também destacar que a tecnologia bicombustível no Brasil registra fases de múltiplos interesses, governamental, de empresas sistemistas, de indústrias automobilísticas, sucroenergéticas, de produtores, entre outros que estejam ligados a fatores energéticos, de tal maneira que regulamentações e normatizações possam surgir ou modificar-se, priorizando os interesses ambientais. Sob esse aspecto, o presente estudo traz uma breve contribuição, após a fase do desenvolvimento da tecnologia do flex fuel, que permite compreender a base estrutural consolidada no que se refere à produção, ao armazenamento, à distribuição e ao fornecimento do etanol hidratado. 
$\mathrm{Na}$ tentativa de contribuir com os agentes de pesquisa e partindo-se do princípio de que o desenvolvimento seja frutífero para questões ambientais, ainda restam algumas indagações que justificam e motivam a pesquisa. Nesta análise, as respostas aos seguintes questionamentos servirão para avanços futuros no meio acadêmico e nos meios gerenciais:

a) Que implicações as indústrias automobilísticas com a tecnologia flex fuel no país levaram para o mercado do combustível etanol?

b) Que diferenças o preço do etanol se apresenta nas diferentes macrorregiões?

c) Como são constituídos os preços do etanol nos postos de revenda?

d) A proporção do etanol misturado na gasolina tem estimulado as diferenças de preços?

e) As desregulamentações de mercado determinam o poder de precificação do etanol?

f) Os usos alternativos da cana-de-açúcar comprimem a oferta no mercado interno do etanol?

g) As distribuidoras distribuem o etanol aos postos de combustíveis e são responsáveis pelas diferenças dos preços?

h) Que implicações a logística e os tributos têm sobre os preços realizados nos postos de revenda?

Diante dessas problemáticas, esta pesquisa visa contribuir na compreensão da dinâmica da formação do preço do etanol hidratado no mercado interno. Outro ponto contributivo do estudo, ao explorar a formação dos preços do etanol hidratado comercializado no mercado interno ao consumidor final, é compreender os aspectos tecnológicos, estruturais, regulatórios, fiscais, logísticos e institucionais existentes como eixo no ajustamento de ofertas e de distribuição do etanol.

Espera-se, desse modo, que esta pesquisa possa contribuir caracterizando a formação dos preços do etanol praticados no posto de revenda no mercado brasileiro, contemplando, também, a sua caracterização na base primária (produtores) até a base secundária (distribuidores) da cadeia do etanol, de forma que os resultados obtidos favoreçam a identificação dos principais determinantes da formação de preços no mercado do combustível de etanol hidratado no país. Nesse sentido, esta pesquisa apresenta uma destinação abrangente, uma vez que poderá auxiliar pesquisadores, consumidor final, instituições e outros agentes envolvidos na cadeia do etanol. Além disso, vale destacar que os resultados de uma pesquisa exploratória inicial dão suporte às pesquisas futuras, sobretudo ao processo de 
comercialização/distribuição do combustível (etanol hidratado). 


\section{FORMAÇÃO DE PREÇOS}

Ao se iniciar o capítulo de fundamentação teórica, é propícia uma breve abordagem da revisão da literatura sobre preços na finalidade de enquadrar a execução da pesquisa sob os seguintes aspectos da formação de preços: contábil/mercado e econômico/social. A pergunta de pesquisa emergiu da necessidade de investigar os impactos ocasionados pelo setor de combustível etanol, que se caracteriza por abordar vários aspectos, dentre os quais está a formação de preços. Em paralelo, as inter-relações com agentes ligados ao setor mostraram que a diferença nos preços do etanol hidratado tem suas múltiplas explicações e não se resume apenas no cálculo de confrontação entre custos, receitas e ganhos. Essa constatação inicial motivou uma revisão da literatura sobre aspectos de formação de preços, custos e mercadológicos acerca do etanol que aparentemente estavam relacionados com a maneira como os preços surgem no mercado e como se caracteriza esse mercado do etanol hidratado.

Com o objetivo de organizar o pensamento e traçar uma linha mestra ao longo dos três capítulos teóricos que seguirão (formação de preços, mercado de etanol e formação dos preços do etanol), o capítulo inicial estruturou-se para construir uma visão abrangente, reunindo, para tanto, os enfoques das teorias existentes e relacionados com o foco da pesquisa. O presente capítulo é organizado e apresentado em sete seções temáticas. Na primeira seção, descreve-se o entendimento sobre formação de preços e custos. Na segunda seção, apresentam-se pesquisas conceituais acerca dos custos de distribuição e comercialização. Na terceira seção, faz-se a revisão de importantes conceitos de economias de escala. Na quarta, abordam-se os elementos custos de produção na formação de preços, inferindo-se que ambos afetam nas decisões e na composição final relativas à determinação dos preços. Na quinta seção, apresentam-se os fatores mercadológicos da formação de preços, imputando-se as principais demarcações teóricas que norteiam a determinação dos preços projetados pelo mercado. No sexto capítulo, a vertente econômica e social sobre formação de preços é brevemente contextualizada, caracterizando frentes reflexivas e complexas quando se trata dos impactos que os preços possam ocasionar. No final do capítulo, sétima seção, sintetizam-se as principais observações pertinentes ao problema de pesquisa. 


\subsection{Abordagens conceituais da formação de preços e custos}

Dentre inúmeras contribuições conceituais acerca de preço, Ferrel et al (2000, p.96-98) afirmam ser este a expressão monetária do valor de um produto ou serviço, podendo ser amplamente definido como o elemento mais flexível do composto de marketing. Para o autor, há dois pontos de vistas a considerar em relação ao preço. Primeiro, para a empresa, preço é a quantidade de dinheiro que está disposta a aceitar em troca de um produto. Para os consumidores, preço é algo que estão dispostos a pagar em troca de um produto. De forma complementar, Sardinha (1995, p. 14) aborda que o preço é o único instrumento pelo qual o gerente pode obter melhor ajustamento entre a oferta que sua empresa faz ao mercado e a demanda existente. Já para Bernardi (2010, p.07), o preço é um fator decisivo na escolha de um produto e para a decisão de compra. Na atualidade, tal importância acentuou-se principalmente pelo aumento da oferta, pelo grau de exigência, pelo aumento do poder de barganha do consumidor e, principalmente, pela disponibilidade de informação.

Para Pindyck e Rubinfeld (1994), o preço representa a expressão monetária do valor de um bem transacionado no mercado. Dentre suas contribuições, destaca-se o processo pelo qual são estabelecidos os preços dos bens no mercado, ou seja, é dada ênfase aos mecanismos de mercado. Isso posto, cumpre salientar que o preço estudado no pensamento administrativo também possui objetivos relacionados com o mercado. Essa constatação também se observa em Bernardi (2010), para o qual a composição e manutenção dos preços no mercado objetivam: maximização dos lucros; maximização do faturamento; crescimento das vendas; e, maximização do mercado. Sob o enfoque quantitativo, Dubois et al (2009), em suas contribuições sobre preços, afirmam que, em qualquer procedimento de industrialização, os preços são os recursos contábeis que indicam e ajudam a controlar a eficiência dos bens e serviços fabricados. Caracterizar os preços, portanto, reflete em determinar o resultado da própria eficiência de produção das empresas.

Em essência, os autores ressaltam que as empresas devem estar orientadas para o mercado na sua definição de preços. Nas economias de mercado (denominadas de livre iniciativa), cada um dos produtores não deve estar interessado apenas no seu negócio e procurar resolver de maneira isolada os seus problemas de preço. Nesse sentido, os autores ressaltam que, para a empresa medir seu grau de eficiência na produção e não apresentar distorções significativas nos preços finais dos bens e serviços que comercializa, elas devem contabilizar seus custos 
buscando sinalizar corretamente todos os insumos que foram utilizados na industrialização. $\mathrm{E}$ dentro de uma concepção esquemática observada em Coelho (2009, p.08), tem-se que a formação de preços baseada em custos revela que a receita deve cobrir os custos operacionais e gerar um lucro, tal como num modelo esquemático simples na Figura 1.

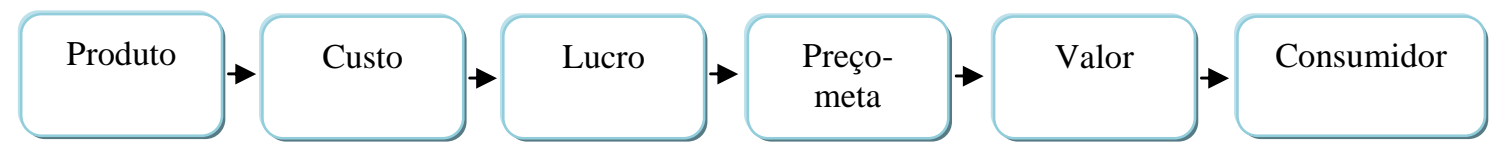

Figura 1- Formação de preços baseada no custo Fonte: Coelho (2009, p. 08).

A Figura 1 expressa os passos para a formação de preço baseado no custo. Percebe-se que o produto gera o custo e, a partir de uma margem de lucro, estabelece-se o preço-meta a ser cobrado do público. Portanto, essa visão de preços baseados em custo conjuga apenas fatores internos à organização. Em contrapartida:

\begin{abstract}
são muitas as variáveis que interferem na sugestão dos preços dos produtos, quase todas interdependentes, tornando-se difícil concentrar-se em alguma como referência, para um cálculo racional. $\mathrm{O}$ conhecimento de custo é essencial à formação de preços, mas depende do volume de produção, o qual depende do volume de venda, que estará em função da demanda. A demanda transcende a qualquer quantificação, dependendo de uma infinidade de fatores não controláveis no nível da empresa, o que evidencia a complexidade da formação de preços. De fato, tal dificuldade remete-se à grandeza de mercado, entre oferta e demanda, pois estas não são estáticas, bem como as dos insumos, das despesas, dos investimentos e do custo de oportunidade dos acionistas. As variáveis acerca desses elementos são dinâmicas e dependem de instrumentos que permitam acompanhar e avaliar resultado desse dinamismo. (SARTORI, 2004, p.14-15).
\end{abstract}

Para Bernardi (2010, p. 07), o que há é uma política de preço que resulta de um processo integrado e da postura estratégica da empresa, que propicia o clima e o contexto, na busca de objetivos globais. É fundamental que a empresa conheça seus limites de preços, o preço ideal, e o forme corretamente, para entender e praticar o que é possível e saudável, de forma a manter-se notadamente num mercado competitivo ou desaquecido, em que por pequenas diferenças se perde o cliente. Esse aspecto remete às abordagens de Coelho (2009, p.08), ao revelar que a formação de preços também deve estar baseada em percepção de valor. Neste método de formação de preço, independentemente dos custos dos produtos, a tomada de decisão dos clientes está em sua percepção de valor proposto pelo mercado. Desta maneira, as empresas buscam mensurar quanto eles estão dispostos a pagar em troca de um bem e serviço. Com base no preço que os clientes desejam pagar e considerando o lucro desejado pelos acionistas, estima-se o custo-meta, isto é, o custo que o produto deve ter, conforme demonstrado na Figura 2: 


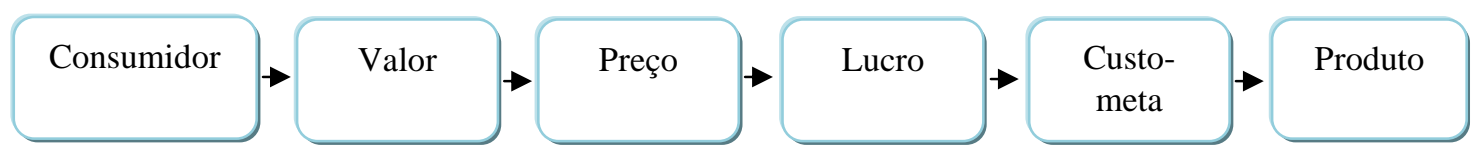

Figura 2 - Formação de preços baseada no mercado Fonte: Coelho (2009, p. 08).

A Figura 2 revela os passos para a formação de preço baseado no mercado. Percebe-se que o mercado acaba delimitando o produto a ser comercializado, visto que sua percepção de valor irá direcionar os administradores a moldarem seus produtos de acordo com o custo-meta que sintetiza a demanda sinalizada pelo mercado. Essas são importantes contribuições teóricas sobre o preço, a partir das quais se nota que ele é praticado num determinado ambiente, que é compreendido como complexo, dada a enorme quantidade de variáveis que existem para estabelecer o preço. Assim, estabelecer preços requer uma política adequada de métodos e processos bem estruturados e definidos. Em síntese, percebe-se que o elemento central das ações de gestão que dão origem à formação de preços seria para definição de um preço de venda referencial que protagonize a eficiência do custo de produção. Ou seja, a contabilização dos custos, ao invés de fixação ou constituição de preço para o mercado, deve representar apenas uma sugestão de preço, uma vez que as variáveis existentes no mercado são complexas.

Quanto aos custos, é necessário abordar que, para qualquer sistema produtivo, se deve estabelecer o custo para produzir para que este possa servir na composição do preço sugerido de venda, levando-se em conta o lucro pretendido. Com base numa multiplicidade de entendimentos sobre custos, cabe ao gestor conhecer sua utilidade nas avaliações e tomada de decisões quanto à formação de preços, devendo interpretar corretamente os elementos de gastos, investimentos, custos e despesas e sua respectiva eficiência produtiva.

De acordo com Dubois et al (2009), gastos referem-se à aquisição de um bem ou de um serviço que vai originar um desembolso da empresa. Normalmente, este desembolso é representado pelo pagamento. O gasto, porém, somente se concretiza quando os bens adquiridos passam a ser propriedade da empresa. $\mathrm{O}$ custo representa todo gasto na aquisição de um ou mais bens ou serviços usados na produção de outros bens e/ou serviços e ocorre somente na atividade produtiva, constituindo-se, dessa forma, em elemento inerente ao processo de produção da empresa. Em outras palavras, o autor sintetiza que o custo significa o valor monetário de recursos utilizados no processo de obtenção ou de elaboração de 
determinado bem ou serviço; em contrapartida, gastos não se relacionam com a produção e não podem ser contabilizados como custos. Portanto, só devem ser incluídos no custo dos produtos ou serviços os insumos necessários à elaboração destes elementos, isto é, sem os quais seria impossível produzi-los. No que compete ao investimento, este representa todo gasto ocorrido na aquisição de bens que serão estocados pela empresa até o momento da sua utilização, isto é, do seu consumo.

Com relação às demais terminologias associadas a preços têm-se:

Gastos que representam tudo o que se desembolsa para atender às finalidades da empresa, por meio de atividades de produção, administração e vendas, inclusive em investimentos. É gasto, do ponto de vista financeiro. Custos são gastos direcionados à produção de bens ou serviços e, portanto, inerentes à atividade de produzir, incluindo a produção em si e a administração da produção. Despesas são gastos inerentes à obtenção de receitas e administração da empresa; portanto, próprios das atividades de venda e administração. Investimentos sãos gastos necessários às atividades da produção e serviços, da administração e das vendas, que irão beneficiar períodos futuros; portanto, ativos de caráter permanente e de longo prazo que, por meio de depreciação ou amortização, irão se tornar custos ou despesas, dependendo de sua origem e natureza. (BERNARDI, 2010, p. 17-18)

Segundo Sartori (2004, p. 15), o custo representa o fator mais óbvio que a empresa pode controlar, utilizado para identificar gastos na produção, ao passo que despesa é o termo utilizado para os gastos que se referem às etapas pós-fábrica, ou seja, nas fases de dispêndios de vendas, gerais e administrativos. De acordo com Martins (1998, p. 41), "a distinção entre custo e despesa é algo fácil, bastando compreender o momento em que o produto está pronto para venda. Até aí todos os gastos são custos, a partir desse momento, despesas."

Com base na visão conjugada das definições sobre custos, percebe-se que há um hiato entre custos e despesas, apesar de ambos serem gastos. Conforme Martins (2001), o hiato descaracteriza-se ao compreender que custos são gastos relacionados aos sacrifícios ocorridos nos processos produtivos, e despesas são gastos necessários para obter receitas. Martins (2000), ainda, traz outro conceito relevante a respeito de custos. Primeiro ele classifica que quando se fala em gastos de uma determinada empresa, o termo é confundido com custos, despesas ou desembolsos na mente das pessoas. Gasto significa sacrifício financeiro com que a entidade arca para a obtenção de um produto ou serviço qualquer, representado por entrega ou promessa de entrega de ativos. Quanto à definição que se tem de custos, pode-se dizer que são gastos relativos à produção de bens e serviços da entidade, cujos exemplos mais claros são o custo da matéria-prima ou de energia elétrica para produção. Diferentemente, as despesas podem ser classificadas como gastos realizados direta ou indiretamente para a 
obtenção de receitas. Em paralelo, Viegas (1986) destaca que é importante classificar os custos em função da estrutura da empresa e com base no volume de produção.

Sobre o processo de aplicação dos custos:

Numa entidade que produza mais que um tipo de produto, deve haver um sistema de custeio de modo a facilitar a identificação do custo real de determinado item, para que o custo seja, portanto, efetivo. Por outro lado, o autor ressalta que a utilização efetiva de um sistema de custeio não se limita apenas à sua importância na avaliação de estoques, uma vez que ele também é um instrumento de suporte voltado ao fornecimento de subsídios importantes à avaliação de desempenho dos gestores, taxa de retorno nas decisões de investimentos, decisões do tipo comprar versus fabricar, formação de preço de venda etc. (BEUREN E ROEDEL, 2002, p. 73).

Como complemento à observação vista sobre a avaliação do desempenho ao arbitrar o sistema de custeio, destaca-se Perez et al (1999, p. 48), que, ao abordar seu entendimento sobre os sistemas de custeio, refere-se à forma de apropriação dos custos de uma determinada empresa aos seus produtos, determinando como principal objetivo de qualquer sistema de custeio determinar o custo incorrido no processo de produção de bens ou de prestação de serviços.

Carmona et al (2007, p.32) afirmam que não há uma fórmula ou metodologia que indique o melhor sistema de custo a ser utilizado em uma organização. Assim, cada empresa possui necessidades específicas e parametrizadas de produção, as quais devem ser analisadas criticamente com o objetivo de definir o melhor sistema de custeio. Já Luz e De Rocchi (1998, p. 29) consideram que "uma correta seleção dos sistemas e critérios que deverão ser utilizados para a determinação e análise dos custos se reveste, desde logo, de transcendental importância para uma correta orientação dos processos gestivos."

Percebe-se que os sistemas de custeio utilizados se aproximam de uma realidade do custo de produção para cada item produzido. Ou seja, essa abordagem é relevante, pois considera a parcela dos custos diretos antes desprezados no computo dos custos totais, o que está em conformidade com a contribuição teórica trazida por Martins (2001), que também aborda o sistema de custeio como método de apropriação de custos para cada item produzido.

Para Bomfim (2006, p. 29), o sistema de custeio é uma maneira de "gerenciar previamente os custos, de modo a alcançar o objetivo da entidade, ao admitir que uma gestão de custo eficiente possa ocorrer em qualquer etapa de produção, desde a fase inicial do projeto do produto." Ou seja, a preocupação é estimar todo o custo envolvido na obtenção do produto e 
não na forma passiva de apenas observar o custo de aquisição. Kato (1993, p. 48) complementa destacando a existência de dois caminhos que a empresa pode seguir para diminuir custos. Um deles refere-se às fases posteriores ao processo de produção, como logística, vendas e serviços aos clientes, enquanto o outro se refere às fases anteriores à produção, como desenho, pesquisa e desenvolvimento e planejamento do produto. Um planejamento adequado, portanto, pode diminuir custos no futuro, uma vez que visa estimar o custo-alvo. De acordo com os estudos de Bomfim (2006, p. 30), "quando o custo atual do produto excede o custo-alvo, muitas ações devem ser tomadas para reduzir alguns ou todos os custos relacionados ao produto." Tal aspecto demonstra que, os vários tipos de ações para alcançar o custo-alvo são identificados como sendo, na primeira categoria, o alcance do custoalvo pelo aumento da produção, ou seja, o custo unitário do produto tende a ter uma diminuição quando o nível de produção é aumentado, daí a importância da economia de escala.

Essas abordagens conceituais motivaram o entendimento de que as empresas devem estar atentas sobre as diferentes maneiras de se compreender custos. Já que custos são passíveis de se controlar e de avaliar o desempenho, seja em relação à sua aplicação ou prevenção quanto ao custo alvo a ser atendido numa situação onde se estima que possa haver uma elevação na produção. Ou seja, a estrutura de custos dos produtos deve levar em consideração cada uma das ações possíveis de serem tomadas e encorajar os departamentos a tomar a decisão que, no longo prazo, gere mais benefícios à empresa. De modo amplo, compreende-se que custo é a soma dos valores de bens e serviços (fatores de produção) consumidos e combinados, sob certa tecnologia, para obter um novo bem ou serviço, e que o custo não pode ser o mecanismo único na determinação de preços, pois deve ser também uma avaliação da eficiência produtiva.

\subsection{Custos de distribuição e comercialização}

De acordo com o Institute of Management Accountants - IMA - (1992), custos logísticos ou de distribuição são os custos de planejar, implementar e controlar todo inventário de entrada (inbound), em processo de saída (outbound), desde o ponto de origem até o ponto de consumo.

Conforme Lima (1999, p. 18-23), o gerenciamento, o controle e a minimização dos custos logísticos têm se mostrado cada vez mais necessários, caso queira a empresa competir no 
mercado, e um de seus principais desafios é conseguir gerenciar a relação entre custos e nível de serviço, pois os serviços agregam valor dependendo da característica de cada cliente, como: redução no prazo de entrega de um produto; disponibilidade e entrega de produtos; e confiabilidade na entrega. Tais exigências se definem como parâmetros de competitividade e, segundo o autor, para atender a todas estas exigências dos clientes e manterem-se competitivas no mercado, as empresas têm, cada vez mais, segmentado seus canais de distribuição e atendimento. Ou seja, esta posição de segmentar promove nos gerentes logísticos uma série de dúvidas sobre a rentabilidade frente à estratégia, bem como frente aos impactos que isso pode causar no custo do nível de serviço oferecido.

Um aumento nos custos logísticos implica numa elevação dos custos totais, razão pela qual a contabilidade deve ser capaz de fornecer informações que possam auxiliar os decisores e ajudá-los a solucionar as seguintes questões:
a) Como os custos logísticos afetam a contribuição por produto, por território, por cliente e por vendedor?
b) Quais os custos que se relacionam com o aumento do nível de serviço ao cliente? Quais benefícios e perdas que eles proporcionam, e quais trocas compensatórias são necessárias?
c) Qual a quantidade ótima de estoque? Qual a sensibilidade do nível de estoque quanto às mudanças nos padrões de armazenagem ou às mudanças nos níveis de serviços a clientes? Qual o custo de manutenção de estoque?
d) Qual o conjunto de modal que deve ser utilizado?
e) Qual a quantidade e a localização de armazéns/depósitos a serem utilizados?
f) Quais são as capacidades ideais das fábricas para compostos e volumes de produtos alternativos? (LAMBERT et a, p. 32, 1998).

Admitindo que o custo de armazenagem influa nos custos logísticos ou de distribuição, e este por sua vez representa um conjunto de atividades para manter, fisicamente, estoques, concluise que tais atividades requerem soluções para questões como localização, dimensionamento de área, arranjo físico, alocação de estoques, configuração dos armazéns, tecnologia de movimentação interna, estocagem e sistemas. Não por acaso, segundo Ballou (2001, p. 202), uma empresa utiliza o espaço de armazenagem por quatro razões básicas: reduzir custos de transportes e de produção, coordenar oferta e demanda, auxiliar no processo de produção e ajudar no processo de marketing.

Peres (2006, p. 39-54), na mesma linha, aborda que os custos de armazenagem interagem ou são influenciados pelos custos de transporte, pois dependem do tipo e modo de movimento. Movimentos de transportes primários, por exemplo, são os transportes de fábrica para armazéns, que aumentam com armazéns adicionais, ao mesmo tempo que podem reduzir custos de transporte de armazéns para clientes, daí a necessidade de análise do custo total, 
focalizada nos serviços logísticos oferecidos, para balancear todos os custos e necessidades. Ainda para o autor, um aumento da quantidade em estoque acarreta um aumento nos custos de armazenagem, pois o estoque só poderá ser movimentado com a utilização de mais pessoal ou com o maior uso de equipamentos.

Ainda a este respeito, Bowersox et al (2001, p. 49) esclarecem que os fatores econômicos de transportes são afetados por sete aspectos específicos: distância, volume, densidade, facilidade de acondicionamento, facilidade de manuseio, responsabilidade e fatores de mercado, tais como intensidade e facilidade de tráfego. Em conformidade, Peres (2006, p. 47) acrescenta a "importância do sistema logístico, cujos embarques podem ser roteirizados e agendados, no intuito de agregar economias de escala, e isso envolve decisões logísticas associadas à consolidação do transporte." Pode-se, por exemplo, roteirizar veículos, criando um pool com vários embarques, utilizando intermodalidade ou estruturando tabelas de embarques que podem ser ajustadas a outros embarques, de tal modo a criar um programa de consolidação de transportes, beneficiando-se, assim, de economias de escalas e, por conseguinte, gerando maior competitividade e menores custos.

Depois de estabelecidos os custos de distribuição, faz-se necessário contextualizar os custos de comercialização, resultantes das negociações comerciais que, por sua vez, impõem condições à logística de distribuição. No que compete aos custos de comercialização, destacam-se todos os gastos realizados no intuito de proceder a um bom contato com o cliente. Kotler (1998) alerta para o fato de que a empresa que se defrontar com aumento na capacidade de produção, além de deparar-se com maiores custos, terá de fazer contratações para fabricação do produto, ou produzi-lo ou alugar instalações para fabricação em larga escala. Nesse aspecto, a capacidade da fábrica será uma decisão essencial. Ainda para o autor, a empresa poderá construir uma fábrica com capacidade menor que o solicitado pelas previsões de vendas, e acrescenta a necessidade de um timing certo para se comercializar um novo produto. Ou seja, é importante considerar o momento ideal para introduzi-lo no mercado, bem como decidir se lançará o produto em uma única localidade, uma única região, em várias regiões, no mercado nacional ou no mercado internacional. Vale lembrar que a maioria das empresas projeta novos produtos para vender no mercado nacional aproveitando as redes de distribuição. 
Quanto à análise de mercados, no contexto dos custos de comercialização, os principais critérios qualitativos recomendados são:

Extensão do mercado, população e nível de vida; distância até aquele mercado e transporte mais adequado; tipo de política comercial existente; tarifas e impostos a que estão sujeitos os produtos importados; restrições cambiais; preços em uso no mercado; grau de domínio no mercado pelos concorrentes; canais mais adequados de comercialização e hábitos de compra dos clientes existentes no mercado; embalagem adequada; documentação solicitada; e estímulos à exportação. (DIAS, 1989, p. 53).

\subsection{Economia de escala de produção}

Na revisão teórica feita em Besanko et al (2000, p. 72), a abordagem sobre economias de escala revela o momento em que se obtém economias de unidade/custo à medida que se aumenta a produção de dado produto ou serviço. Estas são definidas em termos de funções médias declinantes de custos. Ou seja, quando a empresa decidir por aumentar a produção, considerando que todos os insumos sejam variáveis, a melhor forma de se fazê-lo é mudando a escala de operação, aumentando todos os insumos na mesma proporção.

Pindyck e Rubinfeld (1994, p. 27-37) apresentam outro conceito, denominado de elasticidade de escala, que se refere à proporção da variação do nível do produto quando todos os insumos variam na mesma proporção. Mantendo tudo o mais constante, quanto mais substanciais forem os rendimentos de escala, maiores tendem a serem as empresas de um determinado setor. Tipicamente, as empresas do setor de transformação têm maior probabilidade de apresentar rendimentos crescentes de escala que as empresas de serviços, pois a atividade de transformação exige substanciais investimentos em equipamentos de capital.

Ainda a este respeito, Chambers $(1988$, p. 57) menciona que a elasticidade de escala mede como o produto responde a mudanças nas quantidades dos insumos. Entretanto, independentemente da definição, o ideal a saber é que a escala ótima de produção ocorre quando se obtêm retornos constantes de escala, ou seja, quando o produtor está operando com custo mínimo (GARCIA, 2004). De acordo com o autor, as economias de escala medem a variação na produção considerando todos os insumos utilizados no processo produtivo, ou seja, estabelece-se uma medida baseada na função da produção, a qual descreve o máximo de produto que é tecnicamente viável de se produzir com uma determinada quantidade de insumos, quando a empresa opera eficientemente, ou seja, há uma relação técnica. 
Hogendorn (1975, p. 19) pondera que, em grandes indústrias de produção em massa, os custos unitários são relativamente baixos apenas numa grande quantidade produzida. Sendo assim, as empresas que conseguirem um aumento no volume de produção sem aumentarem os seus custos fixos terão ganhos de economia de escala. $\mathrm{O}$ ganho de escala demonstra o aumento percentual na produção quando a empresa aumenta o volume dos insumos de produção em uma dada porcentagem, auferindo vantagem competitiva pela redução de custos médios.

Thompson Junior e Formby (1998, p. 57) chamam a atenção para economias de escalas advindas de uma planta maior relacionada às economias resultantes da produção em massa, por permitirem maiores subdivisões no processo de produção e maior especialização no uso de insumos e fatores de produção (trabalho, capital e supervisão). Nota-se que, além da função produção, há ainda uma relação da economia de escala com a função custo. Em

paralelo, Besanko e Braeutigam (2004, p. 28) determinam que a função custo total é uma relação matemática que mostra como o custo total varia com os fatores que o influenciam, permitindo a determinação de como o custo varia em relação às quantidades de insumos aplicados na produção e ao nível de produção obtido.

Diante das constatações teóricas sobre economias de escala, é possível notar que a busca por competitividade pode ser obtida com a eficiência na produção, decorrente da adequada combinação de insumos e o dimensionamento das plantas produtoras. Nesse aspecto, tem-se que a economia de escala se associa à maximização dos lucros à medida que a quantidade produzida aumenta.

\subsection{O elemento custos de produção na formação de preços}

As considerações conceituais acerca de custos de produção partem de Souza e Clemente (2007, p. 43), os quais associam o conceito de custo de produção com o de custo total do processo produtivo. Para eles, o custo de produção representa, em certo período, o valor de todos os bens e serviços consumidos no processo de transformação de matéria-prima em produto acabado, ou seja, uma definição contábil que também se denomina por custo total.

Na visão de Bacic (2008, p. 49), o custo total deve agregar determinada margem de lucro por estar associado dentro de uma realidade de nível de operação e volume de vendas 
consideradas condizentes com a estrutura da empresa. Além de explorar relações entre custos unitários, volumes produtivos e preços de vendas por produto, sendo estas pertinentes às situações que envolvam grandes volumes de unidades vendidas de um único produto, o autor ainda destaca em seu raciocínio de custo de produção que, frente aos desafios de competitividade, a gestão de custos deve ser pensada nos aspectos concorrenciais e estratégicos, preservando, de certo modo, uma aproximação à vertente econômica, por admitir que a perspectiva de custos não seja apenas um fenômeno de natureza contábil, mas também mercadológico, assemelhando-se, portanto, ao custo econômico.

Para os economistas, custo econômico pode ser definido de dois modos equivalentes: é o valor de mercado de todos os insumos usados na produção; e é também o preço de mercado da forma mais eficiente do emprego de insumos no processo produtivo (BINGER; HOFFMAN, 1998).

Ainda sob essa abordagem econômica os autores complementam o entendimento sobre custo de produção, associando outra definição: custo de oportunidade (representa a melhor alternativa de emprego do insumo); sob esse aspecto é que se caracteriza o custo econômico. Ou seja, o custo econômico contempla o custo de produção e o custo de oportunidade. Vale destacar que o custo de produção de uma organização deve estar relacionado aos objetivos pretendidos de produção e suas respectivas restrições. Partindo-se do pressuposto de que uma organização, dentre seus objetivos, também maximiza lucro, então deverá necessariamente se produzir no menor custo possível.

O custo de produção é, inegavelmente, segundo Bernardi (2010, p. 99), "um dos fatores de grande importância na determinação do preço final dos produtos, uma vez que é muito raro uma empresa vender um bem abaixo do seu custo." Contudo, são vários os fatores determinantes na formação do preço de venda, dentre os quais se destaca a demanda, daí a importância do custo econômico na determinação dos preços. Assim, há formulação para determinação de preços com base em critérios contábeis, cujo preço de venda deva contemplar os seguintes elementos que farão parte integrante da equação final: custo da produção vendida; tributos; despesas; e margem de lucro almejada. Entretanto, o implicador deste método é reconhecido pelo autor devido à ausência de fatores externos relacionados ao mercado, caracterizando a relevância de se empregar o preço de determinado produto com base no custo econômico. 
A natureza da informação de custos na formação de preços, conforme esclarece Sartori (2004, p. 66), compreende o custo como o ponto de partida. Ademais, é necessário considerar a concorrência e a procura pelo consumidor, independentemente dos preços de venda ter uma relação rígida com o custo. Aparentemente, percebe-se um consenso entre as contribuições teóricas acerca do processo de formação de preços com relação ao elemento custo, o qual exerce um papel que difere em sua característica ao desconsiderar fatores externos de acordo com o produto, com a demanda, elástica ou inelástica, com a concorrência, fraca ou forte; se o produto é vendido através de estoques ou sob encomenda, e até mesmo pelo nível de informação capturada pela organização no momento de determinar o nível do preço a ser praticado no mercado.

Os conceitos de custos mais apropriados para a formação de preços diferem em muitos aspectos dos custos usados para apuração de resultados e estoques. Geralmente, os primeiros requerem as seguintes características:

a) os custos devem ser tratados em termos de unidades de produtos;

b) custos de fabricação e outros custos são igualmente importantes e ambos são apropriados a produtos para a obtenção de custo unitário completo para produzir e vender;

c) custos anuais ou planejados são necessários para compor preços, pois tais decisões envolvem vendas a serem feitas no futuro; custos históricos e padrão são significativos apenas à medida que representam guia para estimarem-se custos futuros;

d) os custos devem ser expressos em moeda de mesmo poder aquisitivo dos preços de vendas que estiverem sendo formulados. (SARTORI, 2004, p. 69)

O fato percebido pelo autor é de que os custos de produtos estão limitados à capacidade de produção e vendas, por não poder variar na proporção das necessidades. Como consequência, os custos respectivos a essas capacidades são fixos no curto prazo e o aumento de volume poderá ser considerado pertinente à organização e aos equipamentos atualmente existentes. Por outro lado, no longo prazo, o custo integral de todos os recursos deve ser recuperado no preço de venda dos produtos. Por esse motivo, a apropriação dos custos fixos uniformemente é computada para servir como objetivo de longo prazo na formação de preços e determinar a eficiência da capacidade produtiva.

De um ponto de vista teórico, percebe-se que os custos servem como guias para a administração nas decisões sobre preços, como preço sugestivo. Como sugere Sartori (2004), os responsáveis pela contabilidade de custos têm a função de selecionar o conceito de custos adequado às circunstâncias sob as quais a decisão será tomada e auxiliar a administração na interpretação das cifras envolvidas. O autor argumenta que o papel dos custos na formação de 
preços tem como motivo principal ajudar na estimativa de consequências de lucros, de preços, condições e métodos de vendas etc. Cumpre, então, ressaltar as possibilidades nas quais os custos influenciam nas decisões de preços:

a) o preço pode ser determinado pela adição de uma margem de lucro ao custo, quando não houver preço de mercado estabelecido (produto novo, sem concorrente).

b) enquanto o custo possui um papel decisivo nesse tipo de preço, não tem necessariamente uma relação rígida com o preço de venda, pois preços de venda e margens de lucro precisam ser ajustados ao volume mais lucrativo;

c) o custo pode estabelecer um limite mínimo ao preço, segundo o qual a oferta do cliente poderá ser recusada ou o produto descontinuado;

d) onde existe um preço de mercado já estabelecido pela concorrência ou clientela, o custo serve principalmente para determinar qual tipo de produto e serviço pode ser oferecido a esse preço;

e) quando o preço for estabelecido pelo mercado ou pela clientela, o custo será necessário para medir a lucratividade de produtos, guiando a administração em dirigir as vendas aos canais mais lucrativos e enfatizando a necessidade de controlar custos para que as margens de lucro disponíveis não venham a sofrer erosão por custos excessivos. (SARTORI, 2004, p. 71).

Coelho (2009, p. 57-58) considera que "há erros na formação de preços baseada somente em custos." Atualmente, a conjuntura concorrencial exige do gestor maior dinamismo informacional e precisão decisorial. Neste contexto, percebe-se claramente a importância da formação de preço como vantagem competitiva. Ainda para o autor, é necessário saber a diferença entre fixação de preço e apreçamento estratégico. No primeiro, calcula-se apenas um valor matemático para dar números aos bens e serviços que serão vendidos, tendo como parâmetros os custos. É um cálculo exato, uma expressão monetária. No segundo, a empresa tem condições de melhor administrar e coordenar as variáveis mercadológicas e direcionar seus empreendimentos para se posicionar de forma lucrativa e permanente no mercado.

Portanto, é um modelo menos quantitativo e mais qualitativo, menos exato, mas em consonância com a realidade. Em essência, a abordagem trazida pelo autor revela que o modelo de formação de preços baseado em custos é mais apreciado pelo gestor por uma série de fatores, principalmente pelo fato de o preço estar sob seu controle, já que ele definirá um valor que irá gerar lucro para a empresa, ser prático, para ser aplicado imediatamente, por considerar apenas variáveis internas da empresa, e tangível o suficiente para ser facilmente gerenciável.

Em síntese, observa-se essa importante contribuição. Os gestores, portanto, acabam caindo na tentação dos modelos numéricos baseados em custos (método quantitativo), por sua visão simplista, por ser tecnicamente justo e considerar apenas fatores internos à organização. Porém, na prática, a formação de preços baseada em custos deve ser considerada apenas para nivelar a eficiência da capacidade produtiva, e: 
Esse método faz que haja perda de gestão no que diz respeito a três variáveis básicas: conhecimento do mercado, fixação das variáveis existentes no modelo baseado em custos e diferença entre custo e valor. $\mathrm{O}$ conhecimento de mercado relaciona-se com a falha na formação de preços baseada em custos, isso se deve à falta de sensibilidade por parte dos gestores em discutir as nuances mercadológicas, isto é, todas as variáveis que envolvem a precificação e que devem ser levadas em consideração; e à visão míope de que todos os custos têm que ser repassados ao consumidor; caso os custos da empresa aumentem, terá um aumento também no preço de venda dos seus produtos. (COELHO, 2009, p. 58).

Ou seja, a fórmula é a resposta de tudo e a precificação é a conseqüência de qualquer de suas decisões. $\mathrm{O}$ fato relacionado entre diferenças de custo e valor traz a contribuição do autor, para quem, no modelo de formação de preços baseada em custos, precificar não é uma ciência exata. Isso acontece porque há fatores humanos envolvidos, os quais estão sujeitos a interpretações psicológicas e percepções emocionais. A formação de preços baseada em custos deduz no primeiro momento que apenas variáveis internas da empresa influenciam a precificação, desconsiderando-se os aspectos mercadológicos numa etapa posterior na determinação destes.

Paralelamente a esse aporte teórico, Bernardi (2010, p. 103) descreve que o cenário de mercado na atualidade indica a tendência do mercado de definir o preço que está disposto a pagar, portanto, um limite ou teto. Desse modo, os custos de uma empresa, mais a rentabilidade desejada, definem o preço a estabelecer, ou preço sugerido, enfim, uma espécie de piso. De forma abrangente, o autor defende que há dois aspectos a considerar: preços estabelecidos (piso) e preços competitivos (limite ou teto). Há, normalmente, uma distância entre os dois; na maioria das situações, o preço estabelecido é maior do que aquilo que o mercado desejaria pagar. Ainda de acordo com ele, os preços estabelecidos dependem de um sistema de informações de boa qualidade, dados precisos, sistemas de custeio, informações financeiras e uma correta estrutura de formação de preços, com base nos custos. Em contrapartida, os preços competitivos dependem de coordenação do processo e de uma abordagem sistêmica e integrada, nos custos e despesas, nos estoques, no capital de giro, enfim, na qualidade da gestão da empresa, determinando a complexidade na formação de preços.

Fica claro que a metodologia de formação de preços deve ser entendida como um ferramental estratégico e competitivo, fundamentada e consistente, lastreada em: custos e contabilidade, finanças e aspectos mercadológicos. Para tanto, fatores internos e externos devem ser atributos para formar preços e estes, por sua vez, complexos. Com isso, percebe-se que o 
caminho para a formação de preços não implica em meramente indexar o custo e o preço de venda, mas reavaliar todos os fatores internos e externos envolvidos.

\subsection{Fatores mercadológicos da formação de preços}

Esta seção tem por objetivo apresentar e descrever alguns fatores da formação de preços e como a linha de pesquisa teórica tem contribuído para diferenciar os fatores internos dos externos na formação dos preços.

Formar preços, para Bernardi (2010, p. 99-100), é um processo político devido à complexidade e à responsabilidade envolvidas. O número de variáveis qualitativas e quantitativas, incertezas, probabilidades e eventos a considerar e ponderar, para sua definição, é extenso, abrangendo aspectos internos e externos, interdependências e interações sistêmicas. A complexidade é identificada para o autor em função da análise prospectiva sobre variáveis sobre as quais a empresa tem pouco ou quase nenhum controle, tais como: reações dos consumidores, dos concorrentes, sensibilidade aos preços, hábitos de consumo, padrões de valores, crescente oferta e produtos substitutivos. Tal fato se deve ao constatar que, nas condições de mercado passadas, com menor oferta, com poucas alternativas ou produtos substitutivos, consumidores menos exigentes e demanda aquecida, políticas massificadas e estruturadas no custo, de certa forma até intuitivas e por experiência, funcionavam. Entretanto, ainda para o Bernardi (2010, p. 103), o que ocorre atualmente é exatamente o oposto, acrescido da revolução digital e da personalização em massa, que exige muita análise de dados, precisão, rapidez, flexibilidade, agilidade, adaptabilidade e relacionamento com o cliente. Ou seja, há um fluxo corrente de informações que proporciona o dinamismo e a complexidade na formação de preços. Por fim, a demarcação teórica que se tem, segundo o mesmo autor, é que há uma política na formação de preços, e estruturar essa política de preços, na atualidade, significa um constante desafio aos hábitos, usos e costumes, aos pressupostos e ao status quo. O foco muda, de posições conservadoras para posições agressivas, de banco de dados para processo analítico projetado para explorar grandes quantidades de dados, de posições defensivas e conservadoras para a busca de oportunidades, por meio de políticas eficazes e preços eficientes.

De forma similar, Sartori (2004, p. 66-71) considera que o entendimento claro nas políticas de 
preços deve mostrar a relação entre o ambiente de formação de preços e os objetivos gerais e de mercado da empresa. Adicionalmente, para adotar políticas de preços, deve-se reconhecer a posição da empresa no mercado, as práticas da indústria e a inter-relação entre preços dos vários integrantes do canal de distribuição. Há também que se submeter as políticas de preços aos fatores externos sobre os quais a empresa possui pouco controle e, ainda, estar de acordo com as restrições legais. $\mathrm{O}$ autor ainda defende que um elenco de política de preços não apenas torna a sugestão de preços mais fácil, como também torna possível uma série de preços em vários níveis de distribuição que sejam razoáveis e justificáveis. A rigidez, portanto, deve ser evitada. A flexibilidade, quando uma mudança for necessária, deve ser possível sem prejuízo dos objetivos originais. As políticas de preços devem ser estabelecidas de forma que as alterações na concorrência e no mercado possam ser rapidamente atendidas.

Bernardi (1998, p. 82) afirma que, com a abertura de mercado no Brasil e o acirramento da concorrência interna e internacional, os preços tornam-se vitais à competitividade e à sobrevivência das empresas. Isso porque, num mercado aberto, o preço passa a ser efetivamente um regulador entre oferta e a demanda, além do fato de crescer o poder de barganha do mercado. Nesse sentido, os métodos de formação de preços baseados nos custos e despesas têm que ser cuidadosamente reavaliados e repensados, pois o mercado é cada vez mais exigente e busca custo mais econômico, qualidade, serviços, atendimento e soluções. Sob o enfoque mais recente em política de preço trazido por Bernardi (2010), é possível observar que o eixo principal que norteia os processos de formação de preços, bem como a estratégia e a política comercial, refere-se àquilo que o mercado está disposto a pagar pelo produto ou serviço. Em resumo, a precificação estratégica e a administração dos preços provenientes de uma política de preços são assuntos estratégicos, inseridos no modelo de negócio da empresa, que, quando bem arbitrada, propicia a criação de valor para o cliente, devendo estar plenamente coordenados os acordos comerciais entre os agentes da cadeia.

Do ponto de vista de estratégia de orientação para o mercado, Narver e Slater (1990, p. 48) analisaram que uma empresa orientada para o mercado precisa focalizar sua atenção nas necessidades atuais e futuras de seus clientes, assim como conhecer as forças e fraquezas, capacidades e estratégias de seus concorrentes. Por outro lado, Sartori (2004, p. 79) compreende que os benefícios da orientação para o mercado dependem da realização de negócios. Ou seja, dependem do fato de que a organização tenha a capacidade de oferecer 
produtos e serviços capazes de satisfazer a necessidade e o desejo dos clientes, que componham um pacote de valor que, em contraposição ao preço na equação de valor, resulte num valor aceito pelo cliente e a venda se concretize.

Sartori (2004, p. 102-106) evidencia que não há uma política e um método utilizados que não sejam concebidos dinamicamente nas condições de mercado para a formulação dos preços, assim como as variáveis internas e externas consideradas e os agentes desse processo nas organizações orientadas para o mercado não são plenamente definidos. Entretanto, a política de formulação de preços tem forte influência da necessidade de gerar resultados no curto prazo. O método de formulação de preços, apesar de ser preponderantemente orientado pelos custos, resulta de fatores internos e externos que cooperam na formação dos preços. $\mathrm{O}$ fator externo, considerado para o autor o de maior impacto na determinação dos preços, é a demanda para o produto pelo consumidor. Uma vez que todas as demandas derivam da procura pelo consumidor de um produto específico, é necessário que todos os integrantes do canal de distribuição conheçam qual é a demanda do consumidor. $\mathrm{O}$ autor ainda destaca que não apenas deve ser determinada a demanda, como também a parte a que deve ser visada, a possibilidade de participação nesse mercado e as características dos consumidores relacionadas às necessidades.

Leftwich (1973) considera que, para cada nível de preços definidos por uma empresa, há um impacto a considerar na demanda. Preço e demanda, na maioria dos casos, são correlacionados negativamente, ou seja, se o preço sobe, a demanda tende a cair ou viceversa. De forma complementar, Bernardi (2010, p. 107) argumenta que além do valor percebido, das necessidades e da dinâmica da decisão de compra, o fator sensibilidade ao preço deve ser ponderado, pois se relaciona com a demanda, e o que afeta a demanda e a sensibilidade são os seguintes fatores: desejo e necessidades; produtos substitutivos; número de alternativas similares; peso do valor no orçamento do comprador; benefícios; qualidade e durabilidade; disponibilidade; relação preço-qualidade; e, relação preço-valor.

Assim, o fator externo baseado na demanda de mercado reflete a intensidade com a qual os compradores desejam e estão dispostos a pagar por um determinado item. A quantidade desse item, que qualquer comprador ou grupo de compradores está disposto a comprar em um ponto qualquer do tempo, apesar de depender de diversos fatores, dependerá especialmente do preço 
desse item (SARTORI, 2004). Nesse aspecto, o autor ainda reforça que, quando da utilização de uma estratégia de apreçamento com base na demanda, a ênfase maior dá-se mais influência das necessidades e interesses do consumidor do que na influência dos custos, lucros ou forças competitivas. Adicionalmente, o autor ainda propõe estratégias com base na demanda de mercado, tais como: preço da exclusividade; estabelecimento de preços baixos para estimular o crescimento e aumentar a participação no mercado; estabelecimento de preço que coloca o produto numa posição relativa em relação aos outros, que expressa a relação entre seu valor e seu preço; preços quebrados e redondos, consiste no estabelecimento de preços que terminam em determinado dígito; e o estabelecimento de preço que irá criar um nível desejável de demanda.

Outra característica que determina o fator externo à formação de preços é a concorrência nos preços. Para Bernardi (2010, p. 141), tal fator está diretamente correlacionado às características de diferenciação dos produtos e serviços, comparados com o foco da necessidade do consumidor. Desse modo, quanto maior o foco do consumidor nas necessidades emocionais em produtos e serviços que exijam muita diferenciação ou singularidade, menor a sensibilidade ao preço e menor a concorrência em preços. Quanto maior o foco em necessidades econômicas e baixo nível de diferenciação, maior a sensibilidade e, portanto, a concorrência em preços. $\mathrm{O}$ autor evidencia também a necessidade de se avaliar o que a concorrência está praticando de preços no mercado como fonte de auxílio à fixação.

O enfoque paralelo à abordagem concorrência vista por Ferrel $(2000$, p. 32) revela que, para formação de preços baseada na concorrência, muitas vezes, a tomada de decisão dos consumidores está intimamente ligada à simples comparação do preço de um produto com outro do concorrente. De tal modo que a empresa estabelece seu preço em patamar acima, igual ou inferior ao preço de seus competidores. Tal precificação considera que a concorrência interfere diretamente no valor do produto a ser vendido e, consequentemente, no estabelecimento do preço.

Contudo, tanto a concorrência quanto a demanda, como elementos do fator externo, são variáveis, razão pela qual, de acordo com Bernardi (2010, p. 139), não são de total controle, daí, como já mencionado, a complexidade da formação de preços. Portanto, ao definir um método de preço, a empresa estará buscando um preço específico ou possível que a direcione 
a um ponto em que demanda, preço e retorno se equilibrem. A concorrência vista, portanto, para o autor, é uma influência que o apreçamento com base na demanda, com base no custo e com base no lucro não leva em conta. Esses métodos podem conduzir a preços diferentes, ainda que tenham os mesmos custos, em função das condições de discriminação de preços. No fator externo também há uma sugestão de preços, que dependerá do nível de concorrência existente para o produto, independentemente de seu custo ou da demanda. Os preços poderão ser diferentes se o produto atuar em oligopólio, se é líder ou liderado. (BERNARDI, 2010, p. 243).

Juntamente aos fatores externo na formação de preços, destacam-se as restrições legais. Os governos podem impor restrições aos aumentos dos preços de alguns produtos considerados estratégicos ou de cunho social. Para esse fim, podem ser criados órgãos com a função específica de analisar os custos e a lucratividade dos produtos e das empresas, antes de autorizar um pedido de aumento no preço (SARTORI, 2004, p. 109).

Com relação aos fatores internos servidos como base para formação de preços, destacam-se os custos da empresa, como observado anteriormente. Sartori (2004, p. 109-110) ressalta que, embora seja um preço sugerido, partindo de uma quantificação de dados internos da empresa, a dificuldade de saber exatamente qual o custo dos produtos deve se somar às considerações das forças de mercado, lembrando que os componentes que constituem os fatores internos à precificação são baseados em: custos, mark-up e curva de experiência (corresponde a uma estratégia de determinação de preços mais baixo para aumentar o número de unidades vendidas, o que diminui os custos totais à medida que a empresa ganha experiência na fabricação do produto). Segundo o dicionário Accounting: the language of business, de Davidson et al (1977, p. 50), mark-up é um valor originalmente adicionado ao custo, usualmente expresso como um percentual do preço de venda.

Em paralelo, Santos (1995, p. 57) considera que mark-up é um índice aplicado sobre o custo de um bem ou serviço para a formação do preço de venda. Esse índice deve cobrir os impostos e taxas incidentes sobre as vendas, as despesas administrativas, fixas, as despesas de vendas fixas, ou custos indiretos fixos de fabricação e o lucro, portanto, representa um método de formação de preços baseado em fatores internos. Formações de preços baseadas nos fatores internos referem-se, portanto, às decisões tomadas dentro da empresa, que, ainda 
de acordo com o autor, se relaciona com a gestão interna por compreender aos objetivos de vendas, lucro, crescimento e fator de risco, assumindo o mark-up como sinalizador adicional na formação de preços. Nesse aspecto, classificam-se os seguintes fatores internos que afetam os preços: os gastos (custos e despesas), os objetivos de curto e longo prazo, lucratividade e sua posição funcional. Há que constatar também que, em situações em que os produtos são padronizados, sobretudo em sua funcionalidade, os preços representam concorrência direta. Admitindo-se que o produto possua a mesma finalidade que o do concorrente, nessas circunstâncias, o conhecimento do custo do produto habilita uma empresa a avaliar se será lucrativo vender seu produto ao preço estabelecido no mercado.

Em síntese, para muitos produtores, o processo de sugestão de preços restringe-se simplesmente na apuração de todos os custos relacionados a um produto ou uma linha de produtos e a adição de uma margem de lucro. Tal como afirma Cogan (1999, p. 58), ao revelar que esse método se baseia na aplicação de todos os custos do produto acrescidos da margem de lucro. Entretanto, a principal limitação dessa abordagem é o seu desprezo pelos fatores externos, principalmente a demanda e o valor atribuído ao produto pelo consumidor final, sendo esses fatores externos constituídos por informações dinâmicas e de cunho qualitativo em sua análise. Outro problema que surge é a própria determinação de custo em si, a qual costuma ser apurada pelo seu valor de aquisição, enquanto seu valor de reposição poderia ser bem superior.

Interessante notar as considerações trazidas por Bernardi (2010, p. 219) quanto às flutuações nos preços. O aumento ou redução nos preços é uma decisão complexa que deve ser muito bem pensada, estruturada e comunicada. Oscilações na conjuntura econômica, o cenário de negócios, o poder aquisitivo, entre outras variáveis exógenas são razões para tomar essas decisões. Do ponto de vista interno, as próprias condições competitivas da empresa determinariam a decisão. Em qualquer circunstância, interna ou externa, há ações e reações em cadeia e interdependentes. As causas mais frequentes são: ociosidade; perda de participação no mercado; cenários recessivos; perfil do consumidor; inflação nos custos; demanda aquecida; excesso de oferta; qualidade da gestão; e improdutividade.

Em conformidade, Sartori (2004, p. 98-99) revela que a base para a decisão sobre preços, as informações relativas a mercado, custos e especificações precisam ser reunidas e coordenadas 
com os fatores internos e externos. Nesse caso, cumpre ressaltar que dados quantitativos servem como sugestão de preços e avaliação da eficiência produtiva, não como referência e prática no mercado. $\mathrm{O}$ autor ainda acrescenta que:

As organizações possuem dados e informações a respeito dos mercados, dela própria, de seus produtos e de seus clientes. Essas informações estão disponíveis e servem de base para a identificação de alguns parâmetros desejáveis para o mercado, cuja obtenção ficará sob a responsabilidade do preço, tais como: variáveis do mercado, variáveis da organização, variáveis do produto e variáveis do cliente. Essas variáveis são desejáveis para compor o mercado e formar o preço. $\mathrm{O}$ processo de precificação, dada a complexidade adquirida pelos mercados em função de sua abertura, tem cada vez mais que assumir um caráter científico, ou seja, cada vez mais precisa constituir-se num processo integrado em que as variáveis possam ser controladas e seus efeitos conhecidos, a fim de que o preço formado seja o mais preciso possível. Ou seja, a precificação representa um processo composto por um sistema de informação endógeno e exógeno com diferentes níveis de gestão e com a capacidade de atingir diferentes públicos-alvo. (SARTORI, 2004, p. 101-102).

Ressalta-se, portanto, as seguintes considerações acerca da formação de preços:
a) Admite que a organização possa possuir um sistema de informação condizente, porém incipiente para determinação do preço se este partir para o atendimento somente das necessidades organizacionais de cobertura de custos e de rentabilidade. Ou seja, correspondendo a uma gestão de preços estática;
b) O ideal é que a organização conheça as variáveis necessárias a respeito do mercado, dos clientes que o compõem, de si própria e do produto, e ainda consegue identificar os parâmetros desejáveis para o mercado como uma média dos clientes e gerar um preço que tem o status de preço sugerido;
c) A organização ainda tem a capacidade de flexibilizar preço, caso haja necessidade e de fazê-lo para concretizar o negócio. (SARTORI, 2004, p. 105).

Entende-se que a formação de preços apresenta características dinâmicas e constitui-se numa estratégia de utilização de diferentes preços (sugeridos ou flexíveis) na busca dos melhores resultados junto ao mercado. Daí o processo de formação de preços representar uma política que consagra variados métodos que contemplem fatores internos e externos.

Kotler e Keller (2005, p. 28), ainda, referem-se ao fato de o preço ser flexível, pois, assim, pode ser alterado com rapidez, ao contrário das características de produtos, dos contratos com os canais de distribuição e as promoções planejadas. Ou seja, o preço também informa ao mercado o posicionamento de valor pretendido por uma empresa, para seu produto ou marca.

Há que se considerar também, segundo Nagle e Holden (2003, p. 32), que uma vez identificado o preço no mercado, ações de concorrentes poderão ser iniciadas levando a empresa a analisar estrategicamente quais reações seriam mais adequadas em cada caso. Essencialmente, este tipo de análise visa entender a força do concorrente e o custo da reação de curto e longo prazo, como base para a elaboração de estratégias que permitam o menor 
impacto para a empresa. Nesse sentido, o estudo de Lepsch (1996, p. 78) considera a necessidade da estratégia de formação de preços, como um plano projetado e administrado de forma eficiente, de modo que a fixação de preços seja uma função de custos, percepção do cliente e reações da concorrência. Sob esse aspecto, tem-se a concepção de Drucker (1995, p. 42), que constatou que as empresas estão mudando da abordagem "Preço-dado-Custo" para "Custo-dado-Preço", e isto, ao que tudo indica, tornar-se-á uma regra. Indicar o que os consumidores estão dispostos a pagar permitirá entender os níveis de custos que poderão incorrer desde o estágio de concepção do produto até a sua entrega final ao cliente.

Além do mais, Urdan (2006, p. 135-136) explica que o marketing tem uma concepção mais elaborada do preço, por estar associada ao conceito de valor percebido (a soma dos benefícios sobre a soma dos custos), sob a ótica do cliente. Nesse sentido, o preço tem sua concepção monetária, que é a mais usual pelo consumidor, e vai além do preço pago pelo produto, pois pode acrescentar os custos de operação, manutenção e depreciação do bem. E há também o preço não monetário, que consiste nos custos de tempo, de energia e psicológico para adquirir e utilizar determinado bem, constituído pelos benefícios percebidos pelo cliente.

Outra constatação pertinente à formação de preços considera que em um ambiente de mercado competitivo, em que o desejo de consumir dos indivíduos determina a magnitude da demanda por determinado bem, e a produção das empresas determina a magnitude da oferta desse mesmo bem, é observada por Montoro Filho et al (1998, p. 34), que ponderam: o equilíbrio entre a demanda e a oferta será sempre atingido pela flutuação do preço, agravando ainda mais a complexidade de formar preços. Ou seja, o mecanismo de preços é um vasto sistema de tentativas e erros, de aproximações sucessivas, no intuito de alcançar o equilíbrio entre oferta e demanda.

\subsection{Abordagem econômica e social da formação de preços}

A formação de preços dentro de uma abordagem econômica pode se dar de duas maneiras, clássica e a neoclássica.

Na economia clássica, por exemplo, Karl Marx pensava a gênese de preços por meio de leis de movimentos inerentes ao sistema econômico como um todo. Smith e Ricardo admitem que a 
formação de preços seja como processo que ocorre no tempo, que sofre influências fortuitas, e que está regido por leis de movimento radicadas no sistema econômico como um todo; já na economia neoclássica, há o átomo social para analisar a coerência possível de suas escolhas e, por isso, raciocinam de maneira estática e abstraindo o tempo histórico, com base em funções de oferta e de demanda, as quais sempre definem equilíbrios (PRADO, 2007, p. 02).

A ótica econômica neoclássica na formação de preços, segundo Prado (2007, p. 04-05), sustenta um enfoque contemporâneo a partir desses átomos que são independentes entre si, mas, coletivamente, estabelecem nexos de interdependência por meio das relações de troca. Os indivíduos estão prontos para tomar as decisões necessárias e suficientes que produzem ao fim e ao cabo os preços de mercado. $\mathrm{O}$ ajustamento ao equilíbrio no longo prazo dos preços se faz quando há excesso de demanda num determinado mercado - daí o preço de fechamento das transações tem de subir; em caso contrário, se há excesso de oferta, o preço de equilíbrio tem de cair nesse mercado. Esse embasamento teórico evidencia que a flexibilidade do preço de mercado se dá de acordo com o excesso de demanda ou de oferta. E o ajuste ao equilíbrio da oferta e demanda representa um processo idealizado por meio do qual a informação necessária se difunde plenamente entre os agentes do mercado (produtores e consumidores).

Essa visão de formação de preços no modus economicus clássico da economia versa sobre a crítica dos neoclássicos de que os agentes não tenham racionalidade perfeita ao ponto de obter informações necessárias, e que sejam incapazes de otimizar sua produção ou seu consumo. Ou seja, os agentes econômicos clássicos formam seus preços, e por desconhecerem os modos de funcionamento do mercado agem procurando alcançar os seus objetivos seja no atendimento do melhor modo possível das próprias necessidades, seja na obtenção de um maior lucro. Isso é permissível, movendo-se com base em um conhecimento apenas aproximado sobre os preços, quantidades ofertadas e demandadas, sobre a qualidade dos produtos, assim como sobre outras condições do mercado.

Agora, em uma ótica mais específica e de ordem social, a formação de preços, de acordo com Melo (2002), vem contrastando com um dos principais papéis da agricultura brasileira, a oferta interna de produtos alimentares. O bom desempenho desse papel agrícola foi um dos requisitos fundamentais para que a economia brasileira realizasse um processo de transformação estrutural e chegasse ao ponto em que está hoje, urbanizada, industrializada e com uma indústria altamente diversificada. Para o autor, nenhum país tem vantagem 
comparativa em todos os produtos, o que cria a obrigatoriedade do comércio internacional. Sendo assim, a formação de preços agrícolas do ponto de vista social ajusta-se à ótica dos economistas neoclássicos, cujo tempo e o equilíbrio se estruturam ao grau de informação entre os agentes que ofertam e demandam. Ainda para Melo (2002, p. 19), por exemplo, o ajuste e a respectiva estrutura de preço se dão na relação entre o avanço tecnológico e o preço dos alimentos. Essa relação é extremamente importante, principalmente no que diz respeito à produção de alimentos voltada para o mercado interno. Sua linha de raciocínio se aplica ao considerar que a matéria-prima cana-de-açúcar é a responsável tanto por ofertar açúcar quanto por inibir outros tipos de produção por conta de uma possível expansão desse único produto agrícola.

No entanto, as inovações tecnológicas, sejam elas biológica, química ou mecânica, contribuem para a maior produtividade da agricultura como um todo, proporcionando custos menores de produção e, consequentemente, resultando em produtos com preços menores. Esse talvez seja um dos aspectos mais importantes da contribuição da agricultura no desenvolvimento econômico brasileiro e que converge à linha de raciocínio exposta anteriormente, e isso decorre também da inovação tecnológica possibilitar novos usos, os quais possam concorrer com os anteriores na busca por maior produtividade a partir da matéria-prima. No entanto, Melo reforça dizendo que nunca houve uma tendência ascendente de preços de alimentos no Brasil de maneira duradoura, uma vez que a economia sempre apresentou preços estáveis ou declinantes. E essa tendência de preços declinantes é fundamental para a melhor distribuição da renda - o que beneficia as classes menos favorecidas que podem, então, consumir mais produtos alimentares. Além disso, favorece o aumento do salário real, que libera o poder aquisitivo para a compra de outros bens, e contribui com a saúde e a nutrição da população, aumentando a produtividade no trabalho e, consequentemente, as oportunidades de emprego e de renda mais alta.

Assim, ajustes ao equilíbrio, tal como observado nos postulados neoclássicos, denotam na visão de Melo (2008), uma versão econômica mais social quando se têm em sua flexibilização não só as alterações no preço de mercado, por conta, por exemplo, de fatores tecnológicos admitidos, pelos ofertantes, mas também um processo por meio do qual a informação beneficia a inclusão social. Ainda na concepção do autor:

Uma situação onde há alternativas tecnológicas convergindo não só para produção do açúcar como para outros produtos não alimentares (como, por exemplo, etanol e eteno) conduz ao seguinte 
questionamento: o mercado do biocombustível afetará os preços dos alimentos? Será que na concepção do autor a produção de etanol pode ser feita de forma sustentável apoiada na tecnologia e principalmente na fiscalização governamental? (MELO, 2008, p. 17).

Há, contudo, que se considerar que o processo de desregulamentação não pode, na visão do autor, ser nula, e se essa intervenção e tecnologia não ocorrer, segundo Melo (2008, p. 23), o Brasil poderá enfrentar uma possível falta de alimentos. Atento a isso, o governo tem atribuído esforços para regular mercado, mas não vem intervindo com incentivos que demandam esforços de seu orçamento como na fase do Proálcool. Dentre essas iniciativas governamentais, está a delimitação do percentual de etanol anidro na gasolina, com o objetivo de convergir à elevação na oferta no mercado interno. Por outro lado, deve-se considerar que a formação de preço numa ótica mercadológica também representa elemento fundamental de análise, sobretudo na determinação da participação de mercado e da lucratividade das empresas, como visto na seção anterior.

Assim, enquanto na ordem econômica o preço é orquestrado quando a demanda por certo produto ou serviço é maior que a oferta, ou vice-versa, em busca de um dado equilíbrio; numa vertente mercadológica, o preço tem seu parâmetro entre o valor recebido em dinheiro pelo vendedor em troca de certa quantidade de produtos ou serviços entregue ao comprador. E, desse modo, as decisões a ser tomada em relação aos preços praticados têm de ser levadas em consideração naquilo que se chamou de fatores internos e externos e seu respectivo impacto social, de tal modo a não afetar somente a maximização do lucro da empresa no longo prazo.

\subsection{Síntese da fundamentação teórica}

Considerando a fundamentação teórica referida neste estudo, são aguardadas algumas conclusões a fim de ajudar a refinar a questão central da pesquisa. Por ora, percebe-se que há poucos estudos teóricos e pesquisas acerca da formação de preços que convergem à prática empírica, sobretudo ao mercado específico do etanol hidratado. Foram encontrados, porém, as abordagens teóricas que contribuíram para uma compreensão do presente estudo: custos, formação de preços, distribuição, comercialização e economias de escala.

A literatura tem tratado do tema "a formação de preços" não como se comporta ou constituise para uma organização isolada, e sim como o preço é formado no mercado. As 
considerações admitidas para o entendimento da formação de preços consolidados aos embasamentos teóricos aqui tratados estão envoltas à composição das proposições teóricas sobre formação de preços na ordem econômica, social e mercadológica, custos e economias de escala de produção, de tal modo a não se limitar apenas à visão reducionista e econômica que acaba ofuscando o entendimento sobre formação de preços, e sim buscando o entendimento de como o preço é formado no mercado e que premissas ou fatores são relevantes para sua formação. $\mathrm{O}$ exemplo mais claro é o que ocorre com os preços da matériaprima cana-de-açúcar, que representam em torno de $60 \%$ dos custos de produção (CONSECANA, 2010), por sua vez, relevante para formação de preços às usinas e destilarias no que compete ao fator interno; por outro lado, há fatores externos ligados ao mercado que atuam na dinâmica dos preços por conta da oferta e da demanda.

Assim, a partir dessa base teórica, determinou-se a compreensão mais empírica acerca do mercado do etanol em possibilitar a identificação de fatores ou variáveis que irão convergir na formação dos preços do etanol hidratado, observando as contextualizações da oferta e demanda, seus custos associados ao processo produtivo e distributivo, bem como seus limitadores de usos e diferenciadores geográficos dos preços, tomando-os nessa pesquisa como os principais fatores explicativos na formação dos preços do etanol hidratado.

Indubitavelmente, sob esses aspectos teóricos, admite-se que o tema formação de preços, apesar de ser objeto de interesse por parte de inúmeros pesquisadores, é desafiador, dada a complexidade em relacionar os fatores ou mecanismos que determinam a formação.

Portanto, neste presente estudo, o emprego teórico da formação de preços não objetiva demonstrar como se compõe o preço numa organização produtora, mas sim evidenciar como ele é formado no mercado, sendo praticado por meio dos postos de revenda. Assim, o desafio intelectual sobre o tema aqui pretendido, e, diante da complexidade observada na formação de preço, remete ao estudo sobre uma análise mais abrangente e exógena relacionada a mercados no que converge a fatores que comprimem ou estimulam a oferta e a demanda, pois estes têm impactos diretos na constituição dos preços, limitando-se, assim, em particularizar-se a aspectos mais específicos ou endógenos com relação aos custos inerentes a cada agente ofertante no mercado do etanol, ou seja, a pesquisa busca investigar de maneira qualitativa e quantitativa seu enfoque na formação de preços do etanol hidratado no mercado interno. 


\section{MERCADO DO ETANOL}

A partir deste capítulo, a pesquisa converge para a revisão dos instrumentos teóricos, indispensáveis à obtenção do objetivo central.

Nessa perspectiva, abre-se espaço para uma compreensão elementar do universo sobre mercado do etanol. Dedica-se atenção para a contextualização do etanol no mercado interno: como se caracteriza a demanda e oferta do combustível etanol, quais são suas tecnologias e usos alternativos e principais propulsores na difusão do mercado de combustíveis. Complementa-se com a caracterização do mercado internacional do combustível etanol e os regulamentos ambientais existentes.

Apesar de sua importância para a análise da formação de preços, o tópico sobre preços do etanol seguirá no capítulo seguinte como análise contributiva para a caracterização da causa das disparidades regionais de preços. Nesta seção, o destaque é denso sobre o assunto em que contextualiza a estrutura do mercado de combustível etanol, que foi se consagrando ao longo dos últimos anos, partindo do desenvolvimento tecnológico e produtivo promovido pelo Proálcool até as tecnologias atuais do flex fuel. Neste contexto, a pesquisa descreve seus principais agentes de mercado do combustível etanol, que promovem o cenário tanto do setor sucroenergético quanto das empresas sistemistas no setor automobilístico.

\subsection{Caracterização da demanda do combustível etanol no Brasil}

A cana é a principal matéria-prima do combustível etanol brasileiro, adaptou-se muito bem ao Brasil, e rapidamente se espalhou ao longo da costa durante o período colonial, sendo atualmente cultivada em várias regiões brasileiras. De acordo com dados do Banco Nacional de Desenvolvimento Econômico e Social (BNDES, 2008), a cana é hoje o terceiro principal produto agrícola brasileiro, depois da soja e do milho; ela é responsável por 13,5\% da matriz energética brasileira, apesar de representar apenas 9\% de uso da terra agrícola brasileira.

O aumento do mercado do etanol deveu-se à volatilidade nos preços dos barris de petróleo, o que motivou o governo brasileiro a investir num combustível alternativo: o etanol, o que antes se chamava álcool carburante. Como o foco investigativo é o etanol hidratado, atualmente representativo na matriz energética do país, torna-se necessário destacar brevemente a 
evolução do etanol no mercado nacional. Inicia-se com o governo brasileiro instituindo o Programa Nacional do Álcool - Proálcool, em vista da volatilidade dos preços do petróleo no mercado internacional. À época, o presidente Ernesto Geisel priorizou investimentos direcionados à produção de cana-de-açúcar, de etanol (álcool) e de automóveis movidos a etanol, inclusive com ações que obrigassem todos os postos de gasolina no país a comercializarem etanol. Esse fato culminou com a criação do primeiro veículo movido a etanol, e pela razão de todos os postos de combustíveis terem que possuir uma bomba de abastecimento de etanol, permitiu que se constituísse a principal estrutura formada à sua posterior consolidação.

O Proálcool teve início com a sua criação no dia 14 de novembro de 1975 , pelo Decreto Lei $\mathrm{n}^{\circ}$ 76.593 do Governo Federal, e estendeu-se até 1979. O objetivo era centralizar esforços na produção de Álcool Etílico Anidro Carburante (AEAC), a partir da cana-de-açúcar, para ser usado na mistura à gasolina em motores do ciclo Otto, na proporção de $20 \%$. Isso se deve, devido à primeira crise internacional do petróleo, ocorrida em 1973, quando praticamente quadruplicou o preço do barril de petróleo, de US\$2,70 para US\$11,50, fato que se traduziu em grande prejuízo para a Balança Comercial Brasileira. Na ocasião do primeiro choque, mais de $80 \%$ do consumo interno de petróleo era importado. O autor ainda destaca que o país tinha gastado US\$ 469 milhões com a importação de petróleo em 1972 e a despesa passou para US\$ 2.840 milhões em 1974, representando 32,2\% do valor das importações do país, que, em 1973, para o mesmo volume de petróleo, correspondia a 9,7\%, o que levou à crise energética nacional. (SCANDIFFIO, 2005, p. 27-28).

Ainda paraScandiffio (2005, p. 30), o surgimento do Proálcool não se deveu exclusivamente à primeira crise do petróleo de 1973; houve por outro lado a crise nas exportações de açúcar nacional no final de 1974. Ou seja, as dificuldades financeiras devido à importação de petróleo e à instabilidade do preço do açúcar no mercado internacional, alicerçadas à determinação governamental de buscar a autonomia energética, impulsionaram o lançamento do Proálcool. Esse programa representa o marco na evolução do etanol no mercado brasileiro, a qual caracterizou o mercado demandante, e foi dividida em três etapas: a primeira se inicia em 1975 e termina em 1979, decorrente da elevação nos preços dos barris de petróleo; a segunda etapa, de 1980 a 1990, registra o auge do Proálcool; a terceira etapa estende-se de 1991 a 2003, e apresenta a estagnação do programa na década de noventa, conjuntamente com outra tentativa de reativação do Proálcool em 1996, porém não se sucedendo e encerrando-se então com a desregulamentação do setor sucroenergético.

Na primeira etapa do programa, a expansão da produção de etanol, segundo Santos (1993), passou por dois grandes problemas: o preço pago aos produtores e a questão da estocagem do combustível. Esse fato demarcava a expansão do álcool na época, e na presente pesquisa constata-se que essa preocupação teve como solução tomada o apoio intervencionista por 
parte do governo (representado pela estatal - Petrobras), subsidiando os fretes de etanol, o que já não ocorre mais no setor.

E com relação à estocagem do etanol, surge outro problema relacionado ao Proálcool: nem os usineiros, nem o Instituto do Açúcar e do Álcool - IAA, nem o Conselho Nacional do Petróleo (CNP) assumiram a responsabilidade de estocar, distribuir e comercializar, até o momento em que foi atribuída às distribuidoras a responsabilidade de adquirir o etanol diretamente das usinas, conforme as cotas fixadas pelo Conselho Nacional do Petróleo e transportá-lo para os centros de mistura, refinarias. Ou seja, nesse instante, constituiu-se a base secundária do mercado de combustível etanol.

A segunda etapa do programa versa sobre o período de 1980 a 1990, instituído pelo Decreto Lei de $\mathrm{n}^{\circ} 83.700$ do Governo Federal, em 5 de julho de 1979, com a produção de álcool etílico hidratado combustível (AEHC), atualmente denominado como etanol etílico hidratado carburante (EEHC), para ser utilizado no recém- lançado "carro a álcool”; tratava-se de automóveis com motores ciclo Otto que foram modificados para receber $100 \%$ de etanol hidratado. O desafio na segunda etapa era conquistar, segundo o autor, a aderência ao programa pela indústria automobilística, e esse desafio foi superado em parte pela guerra entre Irã versus Iraque, que, em setembro de 1980, cortou $50 \%$ das importações diárias de petróleo do Brasil, o que impulsionou a venda de carros movidos a álcool ou etanol. (MELO E FONSECA, 1981, p. 58).

Por ora, cabe ressaltar neste estudo que a terminologia álcool será também conhecida por etanol, arbitrando o atendimento à resolução da ANP n. ${ }^{\circ} 9$ de 01 de abril de 2009.

Em continuidade aos desafios da segunda etapa do programa, tem-se que os primeiros veículos movidos a etanol hidratado foram produzidos em ritmo acelerado, porém apresentavam problemas para iniciar seu funcionamento às baixas temperaturas. Este novo tipo de veículo movido somente a etanol hidratado exigiu o desenvolvimento de um novo motor, com uma taxa de compressão mais elevada do que o motor movido à gasolina, e também exigiu o desenvolvimento de novos materiais resistentes à corrosão, aplicado a peças de vários veículos. Cabe enfatizar que, no início do Proálcool, o etanol produzido a partir da cana-de-açúcar apresentou-se como uma alternativa viável comparado ao uso da gasolina, mesmo em ocasiões em que os motores à gasolina tivessem que ser convertidos em motores movidos a etanol porque os fabricantes ainda não tinham começado a produzir veículos movidos a etanol em larga escala. Segundo Santos (1993, p. 34), o comércio de veículos movido a etanol, que era de $0,4 \%$ em 1979 , foi para $25 \%$ sobre o total das vendas em 1980 , e essa trajetória foi ascendente até 1986. 
Os incentivos prosseguiam. Conforme Moraes (2000, p. 42), coube ao governo estimular a demanda dos carros movidos a etanol hidratado, pois as montadoras aguardavam o aval dos consumidores para iniciar sua fabricação em série. Fixou-se, inicialmente, o preço do etanol hidratado a uma relação de $65 \%$ do valor da gasolina, prazos mais longos de financiamento para a compra de carros a etanol, e abertura dos postos de abastecimentos para carros a etanol durante todo o final de semana, o que não acontecia para a gasolina.

Segundo Scandiffio (2005, p. 39), o programa que contemplava o uso do combustível AEHC apresentou seu auge por volta de 1989, quando atingiu 37,8\% da frota brasileira de automóveis e comerciais leves, conforme apresentado no Gráfico 1. Nesse ano de 1989, o consumo de etanol hidratado foi de 10,8 bilhões de litros.

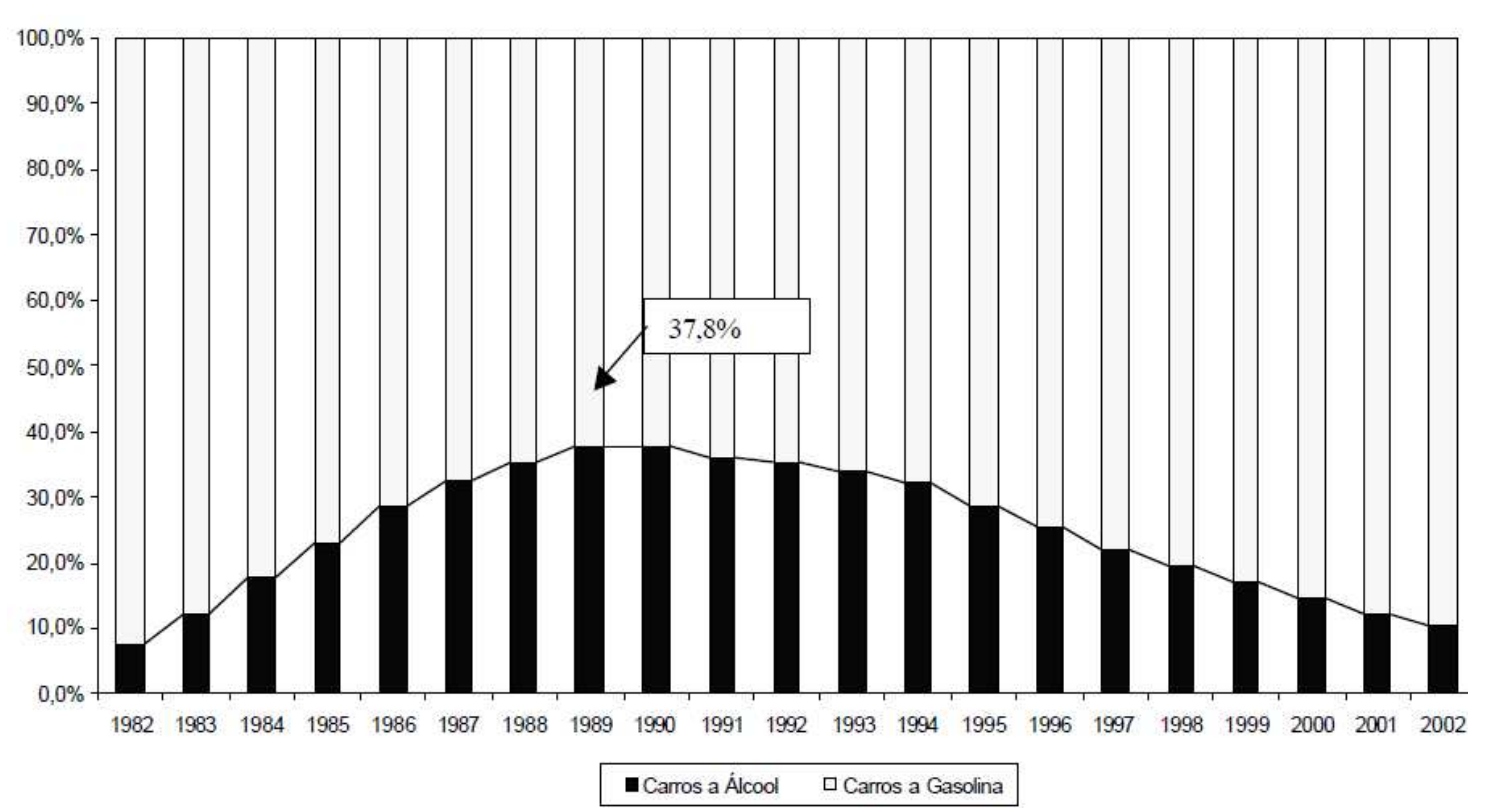

Gráfico 1 - Participação percentual dos carros a etanol hidratado carburante e gasolina na frota nacional de veículos leves (1982-2002)

Fonte: Scandiffio (2005, p. 39).

De acordo com dados da Anfavea (2010b), a produção de carros a etanol, que teve seu início com 4.614 unidades em 1979, saltou para 254.001 em 1980. E, em 1985 atingiu 697.731 unidades, chegando a representar $66,4 \%$ da produção total de veículos nacionais, mas no ano de 2002 caiu em torno de 56 mil, cerca de 10\% da produção total. Em paralelo a essa análise, Teixeira (2005) ressalta que as vendas de automóveis movidos a etanol hidratado começaram a ocorrer em 1981, e em 1985 e 1986, a produção atingiu 90\% de todos os veículos novos comercializados no país, dado a credibilidade do consumidor pela tecnologia do motor movido a etanol e ao baixo preço do combustível pago na revenda. 
Entretanto, Santos (1993, p. 57) destaca que o ano de 1985 representou o marco em que iniciava o declínio da fase de expansão do Proálcool. Para o autor, o declínio do Programa foi provocado, na realidade, pela deficiência no planejamento, o que levou a um desajuste entre a oferta do combustível renovável e a produção de carros movidos a etanol, implicando, por sua vez, na demanda. Ou seja, a demanda de etanol hidratado crescia regularmente, mas a produção (oferta) parou de crescer a partir de 1985. Isso se deveu ao fato de os preços internos do combustível começar a cair em razão da queda no preço do barril do petróleo, uma vez que o preço do etanol não podia ser superior aos $65 \%$ do preço da gasolina. Dessa maneira, a diminuição do preço do petróleo - a partir de 1986 - refletiu diretamente no preço da gasolina, o qual servia de referência para o preço do etanol hidratado, diminuindo, consequentemente, a competitividade do combustível renovável e a demanda por veículos movidos a etanol, acrescendo-se o fato de ser uma tecnologia que ainda empregava dificuldades na partida a frio, o que tornava o veículo à gasolina mais eficiente comparativamente. A Petrobras, também, contribuiu para o declínio do programa, pois, embora o controle da estatal via distribuição do etanol combustível tivesse servido aos interesses da Petrobras, a partir de 1986, este controle passou a ter custos excessivamente altos, visto que a frota de etanol no país havia aumentado, ou seja, os subsídios dados aos fretes, por conseguinte, oneravam os custos da Petrobras - responsável pela distribuição do combustível etanol na época.

Entre outros fatores que contribuíram para este fato, Castro et al (1994, p. 33) apontam que o congelamento dos preços de venda ao consumidor durante cinco meses, em 1985, em decorrência de medidas antiinflacionárias, era diferente ao preço de aquisição junto ao produtor. Este era determinado independentemente pelo Instituto do Açúcar e do Álcool (IAA), de acordo com os custos de produção. Para o autor, o efeito de todos esses fatores foi que, após 1986, a participação desse tipo de veículo no mercado nacional reduziu-se gradualmente em relação à produção do etanol. Tal fato se agravou no momento em que os preços no mercado internacional do açúcar tornaram-se atraentes e motivavam as usinas a aumentarem a produção de açúcar para exportação, enfraquecendo, assim, o mercado nacional da produção de etanol. Isso demarcava um cenário cuja demanda pelo combustível etanol, estimulada pelo aumento na frota de carros movidos a esse tipo de combustível, não acompanhava a oferta de etanol que se constituía. 
Em contrapartida, a gasolina, além do mais, constituía-se na maior fonte de receita líquida na comercialização interna de derivados de petróleo, sendo utilizada pela Petrobras para financiar suas atividades de exploração de petróleo e subsidiar o consumo de derivados de relevância social, como a nafta e o Gás de Petróleo Liquefeito (GLP). Ou seja, a Petrobras passou a diminuir a compra de etanol, comprometendo a renda dos produtores, tendo, como consequência, a diminuição de seus estoques e redução nos custos com a distribuição, implicando, por sua vez, na oferta de etanol.

Conforme dados da Anfavea (2010a), a consequente falta do produto nas usinas produtoras de etanol destruiu a imagem positiva gerada pelo combustível alternativo, acarretando uma queda acentuada em sua demanda. Como resultado, a produção de veículos movidos a etanol sofreu uma redução de $13 \%$ no país. Os subsídios também foram reduzidos e o etanol hidratado perdeu competitividade perante a gasolina. Consequentemente, Teixeira (2005, p. 14), revela que as vendas de veículos novos movidos a etanol caíram para 4\% em 1994 e 0,56\% sobre o total de carros comercializados em 1996. Estes fatores contribuíram para a fase de declínio do Proálcool, que, aliado a problemas técnicos característico de processos inovadores de desempenho, tornou os motores movidos a etanol como inferiores aos à gasolina, resultando na diminuição de sua demanda, ocasionada por problemas como: motores mais fracos do que os motores tradicionais, menor eficiência, dificuldades com partidas a frio, problemas de corrosão etc. Seu agravante ainda se dava devido ao valor que o veículo perdia no mercado secundário (veículos usados). Ou seja, veículos a etanol tiveram seu valor gradualmente perdido no mercado secundário, custava menos comparados ao veículo movido à gasolina, e, diante desse quadro, eles praticamente desapareceram das linhas de montagem.

Scandiffio (2005, p. 45) ressalta que o efeito da diminuição na demanda pelo etanol resulta do fato de que o contexto desse mercado se apresentava na sua fase de declínio, isso porque cerca de 28 destilarias autônomas, financiadas pelo Proálcool, teriam encerrado suas atividades na safra 1989/90. Em consonância à crise instalada, a autora destaca que, em 1989, houve greves e boicotes dos canavieiros e fornecedores independentes de cana-de-açúcar, inclusive ameaça dos próprios produtores de parar a produção de etanol, além de denúncias de comercialização clandestina de etanol.

Como consequência, dá-se a terceira etapa do Proálcool, que compreende a década de 1990 
até o ano de 2003. Compreendida como a fase de estagnação do programa, Scandiffio (2005) atesta que o marco nesse período se inicia logo nos primeiros anos do governo de Fernando Collor de Mello, ao aderir aos postulados neoliberais consolidados no Consenso de Washington - cujas 10 diretrizes convergem para dois objetivos básicos: drástica redução do papel do Estado na economia, e abertura às importações de bens e serviços e à entrada de capital de risco no país. Essas mudanças se traduziram em uma maior internacionalização da produção e das finanças da economia brasileira, as quais também eram amparadas pela Constituição Federal de 1988. É quando se institui a desregulamentação do setor sucroenergético, ou seja, estava dentro de um contexto de liberalização econômica ao que o país aderiu. Cabe contextualizar as constatações apontadas por Santos e Burity (2002, p. 29), quando afirmam que a abertura do mercado promovida pelo Presidente Fernando Collor de Mello, por meio da liberalização das importações de veículos, forçou a indústria a buscar maior qualidade e níveis de produtividade. Isso, posteriormente, motivou empresas sistemistas ligadas ao setor automobilístico a empregarem a tecnologia flex fuel.

A terceira fase do Proálcool demarca o fim do programa. Uma das primeiras medidas foi a extinção, em 1990, do Instituto do Álcool e do Açúcar - IAA, que havia sido criado em 1933, por meio do Decreto Lei $\mathrm{n}^{\mathrm{o}} 22.789$, sob o regime do Presidente Vargas, que, por sua vez, tinha forte atuação no controle sobre a produção, preços, destino do açúcar, além de defender que o etanol deveria ser fabricado em destilarias autônomas, localizadas em regiões não açucareiras, pois temia (o IAA) que um desvio na matéria-prima prejudicasse a fabricação de açúcar, perdendo-se, assim, espaço no mercado internacional (SZMRECSÁNYI, 1979, p. 77).

Segundo Moraes (2000, p. 59), as atribuições do IAA foram transferidas para a Secretaria do Desenvolvimento Regional da Presidência da República, até que, em 1991, foi criada a Comissão Consultiva Nacional de Açúcar e Álcool, com a participação dos seguintes setores: Ministério da Economia, da Agricultura e da Infraestrutura, das Secretarias de Ciência e Tecnologia e de Assuntos Estratégicos da Presidência da República, representantes da indústria privada de açúcar e etanol, fornecedores de cana-de-açúcar e trabalhadores do setor. Ou seja, o setor sucroenergético chancelou sua desregulamentação por meio dessa comissão consultiva, que encerrou o monopólio público na comercialização do combustível etanol, cujo domínio se fazia tanto do lado da oferta (fixação de cotas e preços), quanto da demanda, controlando a exportação, o mercado interno, os estoques etc., do açúcar e do etanol, os quais 
foram feitos por cerca de sessenta anos por meio do IAA.

Dada a desregulamentação, o mercado de etanol passou a buscar demanda no exterior. Nesse aspecto, Moraes (2000, p. 61) destaca o surgimento, em janeiro de 1999, na região CentroSul, da Brasil Álcool S/A, cuja principal função era comercializar a produção do etanol no mercado interno e também realizar a exportação de etanol combustível, uma vez que o setor gerava em torno de 1,2 bilhões de litros de excedentes. O autor ainda destaca que:

As usinas pertencentes à Brasil Álcool respondiam por $85 \%$ da produção da região Centro-Sul, que compreende os Estados do Paraná, São Paulo, Minas Gerais, Espírito Santos, Mato Grosso do Sul, Mato Grosso e Goiás, onde se concentram as principais unidades produtoras de etanol. Ainda para o autor, a coordenação entre os produtores quanto à exportação contava também com a Bolsa Brasileira de Álcool (BBA), criada em 22 de maio de 1999, e tinha como propósito funcionar como uma corretora de propriedade dos produtores, em que os sócios assinavam um contrato de adesão para a venda total de sua produção, havendo punição no caso de não cumprimento do acordo. (MORAES, 2000, p. 62).

Moraes (2000, p. 62-64), em meio a todo esse cenário compreendido na terceira etapa, o setor sucroenergético, após a desregulamentação, trouxe uma preocupação quanto ao controle dos preços do etanol no mercado interno, sobretudo a partir da safra 1998-99, uma vez que o Governo Federal havia deixado de fixar os preços do etanol anidro e hidratado, e do açúcar, devido à desregulamentação.

Surge, portanto, um novo modelo de relacionamento entre os produtores de cana-de-açúcar, usineiros do setor sucroenergético, refinarias e distribuidoras, em que prevaleciam as regras do livre mercado que perduram até hoje. Esse novo modelo de comercialização admite que o preço para a cana-de-açúcar pago aos produtores (plantadores) passe a ser fixado a partir de duas variáveis: quantidade de Açúcar Total Recuperável (ATR) e os preços dos derivados (etanol anidro e hidratado) na condição P.V.U. (Posto Veículo Usina) no Estado de São Paulo, para o mercado interno e externo. Ou seja, as usinas compram ATR e vendem ATR modificado, em forma de açúcar e etanol; já no caso do P.V.U., uma empresa distribuidora de etanol contrata uma transportadora para retirar o produto na usina que lhe vendera. Esse modelo é gerido pelo Conselho dos Produtores de Cana, Açúcar e Álcool do Estado de São Paulo (Consecana), constituído desde 1997, e formado por membros da União da Agroindústria Canavieira do Estado de São Paulo, ÚNICA (representando o setor empresarial), e a Organização dos Plantadores de Cana-de-açúcar do Estado de São Paulo (Orplana), representando os produtores. 
Assim, a abertura comercial, em 1990, desregulamentando o setor sucroenergético, gerou várias alterações na esfera pública e privada, dentre as quais estão as exportações de açúcar e etanol, que foram privatizadas, o fim das cotas de produção de açúcar e a liberação do preço do etanol. E, segundo Moraes (2000, p. 64-69), a medida compensatória para as usinas nessa terceira etapa, no intuito de suprimir reduções na demanda de etanol, foi com a rolagem de suas dívidas em condições favoráveis, além de algumas vantagens tributárias para o setor automobilísticos na venda de carros a etanol, como o IPI diferenciado. Cabe enfatizar que, com o processo de desregulamentação, a comercialização não obedecia mais os planos de safra, mas sim a disponibilidade de etanol programada dentre os produtores, que já não contavam mais com os mecanismos de complementação de preços. Sob esse aspecto, as disponibilidades mensais de etanol passaram a ser apresentadas pelas usinas, e o Sindicom ficou a cargo de expor o volume da demanda que era dividido entre a disponibilidade de cada produtor para atender à negociação. Para o autor, a disponibilidade em atender aos pedidos das distribuidoras era calculada considerando a velocidade de produção de cada unidade no decorrer da safra. Esse cálculo gerava o direito de comercialização de cada produtor, procedimento que foi adotado durante as safras de 1993/94 a 1998/99.

Atualmente, as negociações na compra e venda de etanol se dão por meio de diferentes participantes do setor sucroenergético, conforme descrito na Figura 3. As negociações, basicamente, são caracterizadas por operações no mercado à vista de combustíveis (conhecido como mercado spot). Há, também, contratos com quantidades fixas e preços corrigidos por indexadores, tais como os Indicadores de Preço de Etanol Anidro e Hidratado CEPEA/ESALQ. O governo tem também participado da comercialização por meio dos leilões (de compra e venda) que são adquiridos pela Petrobras e organizados pela Agência Nacional de Petróleo - ANP.

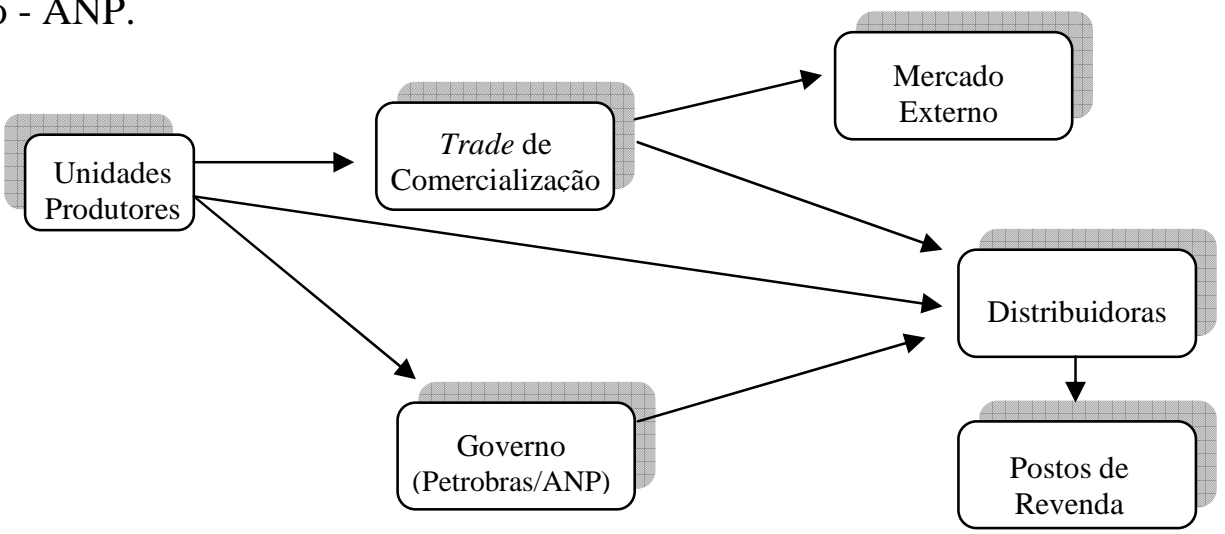

Figura 3 - Relações de comércio entre os agentes do setor sucroenergético na comercialização de etanol Fonte: Marjotta-Maistro (2002, p. 32). 
Conforme o Sindicato Nacional das Empresas Distribuidoras de Combustíveis e de Lubrificantes - SINDICOM, o etanol hidratado para fins combustíveis é adquirido atualmente pelas distribuidoras e direcionado para os postos de revenda localizados em todas as regiões do país (totalizando cerca de 37 mil postos, no ano de 2010). O Sindicom, no ano de 2010, contou com 202 distribuidoras, de um total de 508 existentes atualmente no mercado nacional, sendo também responsável por $60 \%$ do abastecimento de etanol dentre os 37 mil postos de combustíveis do país.

Para Farina (2010, p. 37), a desregulamentação do setor favoreceu a entrada de novos distribuidores no mercado e propiciou o emprego da logística como arma competitiva no mercado de combustíveis brasileiro. Esse novo cenário de comercialização foi se constituindo no início do século XXI, conjuntamente com a indústria automobilística, por estar ativamente envolvida no mercado de combustíveis alternativos por meio de seus motores diferenciados (flex fuel), redesenhando um novo quadro de demanda no mercado interno. $\mathrm{Ou}$ seja, o setor automobilístico, após a terceira etapa do Proálcool, respondeu com uma queda nas vendas de carros movidos a etanol. Porém, em março de 2003 avistou um novo cenário com a introdução de uma nova tecnologia para motores ciclo Otto, o motor flexível, o qual, a partir de um único alimentador, aceita tanto o combustível gasolina quanto o etanol hidratado, perfazendo um novo cenário de demanda pelo combustível etanol.

É reconhecido que o desenvolvimento em outros campos, por exemplo, híbridos ou veículos a hidrogênio, afetará diretamente a demanda para o veículo movido a etanol. Contudo, evidencia-se que o etanol tem exercido um importante papel, dadas as circunstâncias estruturais formadas a partir do Proálcool até as tecnologias hoje estabelecidas nas indústrias automotivas (flex fuel), sobretudo quanto ao seu canal de distribuição, ao permitir que cada posto de combustível possuísse uma bomba de abastecimento a etanol, e, claro, considerando também seu aspecto ambiental, dado que é consagrado como energia limpa.

Identificada a caracterização do combustível etanol no mercado brasileiro, cabe agora contextualizar sua grandeza no atual seguimento sucroenergético. Segundo Neves et al (2009, p. 15-21), "o sistema agroindustrial sucroenergético, que contempla a cadeia produtiva do etanol, exerce uma movimentação de mais de US\$ 80 bilhões por ano." Com base nessa cifra, os autores argumentam que a cadeia sucroenergética possui uma característica de suprir 
produtos de maneira sustentável, com energias mais limpas e utilizadas por veículos que se movimentem a etanol. E estima-se que do total de combustíveis consumidos no Brasil por automóveis leves em 2015, 80\% já será o etanol. Ainda, dentre os dados apontados pelos autores, revela-se o Produto Interno Bruto - PIB do setor sucroenergético, que foi de US\$ 28.153,10 milhões, equivalente a 1,5\% do PIB nacional. Mais dados podem ser vistos na Tabela 1, que apresenta o potencial produtivo com tributos, e sem os impostos estimados sobre as vendas (IPI, ICMS, PIS e COFINS). É possível observar que o etanol é o principal produto na cadeia sucroenergética, representando cerca de $60 \%$ do total.

Tabela 1- Estimativa do Produto Interno Bruto do Setor Sucroenergético com base nos Produtos Finais (2008)

\begin{tabular}{|c|c|c|c|c|c|c|}
\hline \multicolumn{2}{|c|}{ Produto } & \multicolumn{2}{|c|}{$\begin{array}{l}\text { Mercado Interno } \\
\text { USD (milhões) }\end{array}$} & \multirow{2}{*}{$\begin{array}{l}\text { Mercado Externo } \\
\text { USD (milhões) }\end{array}$} & \multicolumn{2}{|c|}{$\begin{array}{c}\text { Total (MI + ME) } \\
\text { USD (milhões) }\end{array}$} \\
\hline & & $\begin{array}{l}\text { Com } \\
\text { impostos }\end{array}$ & $\begin{array}{c}\text { Sem } \\
\text { impostos }\end{array}$ & & $\begin{array}{l}\text { Com } \\
\text { impostos }\end{array}$ & $\begin{array}{c}\text { Sem } \\
\text { impostos }\end{array}$ \\
\hline \multirow{3}{*}{ Etanol } & Hidratado & $11.114,50 \mathrm{a}$ & $9.105,10$ & 23,78 & $11.138,28$ & $9.128,88$ \\
\hline & Anidro & $2.972,89 b$ & $2.250,88$ & $2.366,33$ & $5.339,22$ & $4.617,21$ \\
\hline & Não energético & $438,78 \mathrm{c}$ & 351,57 & n.d. & 438,78 & 351,57 \\
\hline Açúcar & & $5.297,14 d$ & $4.455,83$ & $5.482,96$ & $10.780,10$ & $9.938,79$ \\
\hline Bioeletricidade & & $389,63 \mathrm{e}$ & 242,87 & n.d. & 389,63 & 242,87 \\
\hline $\begin{array}{l}\text { Levedura e } \\
\text { Aditivo }\end{array}$ & & 21,41 & 19,43 & 42,20 & 63,61 & 61,63 \\
\hline $\begin{array}{l}\text { Crédito de } \\
\text { Carbono }\end{array}$ & & n.d. & n.d. & 3,48 & 3,48 & 3,48 \\
\hline & Total & $20.234,35$ & $16.425,68$ & $7.918,75$ & $28.153,10$ & $24.344,43$ \\
\hline
\end{tabular}

a- venda dos postos considerando os mercados formal e informal.

b- venda das usinas para as distribuidoras considerando os mercados formal e informal.

c- soma das vendas de açúcar das usinas para a indústria e as vendas do varejo.

d- soma das vendas de açúcar das usinas para a indústria e as vendas do varejo.

e- venda das usinas nos leilões de energia.

Fonte: Neves et al (2009, p. 02).

Neves et al (2009, p.03-05) apontaram que, no ano de 2008, a comercialização do etanol gerou um faturamento nas usinas de US\$ 12.417,36 milhões (incluindo as vendas para o mercado externo e interno); nas distribuidoras de combustível foi de US\$ 8.624,05 milhões e nos postos de revenda foi de US\$ $10.346,70$ milhões. Segundo os autores, o faturamento nesses respectivos segmentos tem sido superior à comercialização do açúcar, que gerou uma movimentação financeira nas usinas de US\$ 9.765,08 milhões (mercado externo e interno). Contudo, mesmo que seja favorável a venda de etanol pelos produtores, é necessário avaliar a rentabilidade e cenários pertinentes ao momento, como por exemplo: quebras de safra da 
produção do açúcar no exterior e volatilidade cambial.

E ainda segundo os autores, no que compete aos contratos de venda de bioeletricidade, gerada a partir do bagaço da cana-de-açúcar negociado em 2008, o setor gerou um faturamento anual de US\$ 389,63 milhões, e esse tem sido um subproduto que agrega valor ao produtor em níveis rentáveis, admitindo também ser superior se o produtor optasse por reaproveitar o bagaço para a produção de etanol (lignocelulose). Ademais, destacam que, além do combustível etanol ser representativo em volume de vendas, no mercado interno, no ano 2008, foram consumidos 14,08 bilhões de litros de etanol hidratado. O principal motivo deste crescimento foi a introdução dos carros com motores flex fuel, que em 2008 responderam por 90\% da produção dos automóveis comerciais leves no Brasil. A Tabela 2, a seguir, traz a evolução do carro flex fuel no mercado brasileiro, permitindo avaliar o quanto essa tecnologia ganhou aceitação pelo consumidor a partir de 2003. 
Tabela 2 - Venda de automóveis e veículos leves no Brasil (1979-2009)

\begin{tabular}{|c|c|c|c|c|}
\hline \multirow{2}{*}{ Ano } & \multicolumn{3}{|c|}{ Automóveis e comerciais leves } & \multirow{2}{*}{ Total } \\
\hline & Gasolina & Etanol & Flex fuel & \\
\hline 1979 & 905.706 & 3.114 & - & 908.820 \\
\hline 1980 & 626.467 & 240.643 & - & 867.110 \\
\hline 1981 & 344.467 & 136.242 & - & 480.709 \\
\hline 1982 & 365.434 & 232.575 & - & 598.009 \\
\hline 1983 & 78.618 & 579.328 & - & 657.946 \\
\hline 1984 & 33.482 & 565.536 & - & 599.018 \\
\hline 1985 & 28.655 & 645.551 & - & 674.206 \\
\hline 1986 & 61.916 & 697.049 & - & 758.965 \\
\hline 1987 & 31.190 & 458.683 & - & 489.873 \\
\hline 1988 & 77.312 & 566.482 & - & 643.794 \\
\hline 1989 & 260.821 & 399.529 & - & 660.350 \\
\hline 1990 & 542.855 & 81.996 & - & 624.851 \\
\hline 1991 & 546.258 & 150.982 & - & 697.240 \\
\hline 1992 & 498.927 & 195.503 & - & 694.430 \\
\hline 1993 & 764.598 & 264.235 & - & 1.028 .833 \\
\hline 1994 & 1.127 .485 & 141.834 & - & 1.269 .319 \\
\hline 1995 & 1.557 .674 & 40.706 & - & 1.598 .380 \\
\hline 1996 & 1.621 .968 & 7.647 & - & 1.629 .615 \\
\hline 1997 & 1.801 .688 & 1.120 & - & 1.802 .808 \\
\hline 1998 & 1.388 .734 & 1.224 & - & 1.389 .958 \\
\hline 1999 & 1.122 .229 & 10.947 & - & 1.133 .176 \\
\hline 2000 & 1.310 .479 & 10.292 & - & 1.320 .771 \\
\hline 2001 & 1.412 .420 & 18.335 & - & 1.430 .755 \\
\hline 2002 & 1.283 .963 & 55.961 & - & 1.339 .924 \\
\hline 2003 & 1.152 .463 & 36.380 & 48.178 & 1.237 .021 \\
\hline 2004 & 1.077 .945 & 50.949 & 328.379 & 1.457 .273 \\
\hline 2005 & 697.004 & 32.357 & 812.104 & 1.541 .465 \\
\hline 2006 & 316.561 & 1.863 & 1.430 .334 & 1.748 .758 \\
\hline 2007 & 245.660 & 107 & 2.003 .090 & 2.248 .857 \\
\hline 2008 & 217.021 & 84 & 2.329 .247 & 2.546 .352 \\
\hline 2009 & 221.709 & 70 & 2.652 .298 & 2.874.077 \\
\hline
\end{tabular}

Fonte: UNICA (2010).

Na Tabela 2, os dados até 2004 referem-se a vendas internas no atacado e incluem somente os veículos do ciclo Otto (não estão contabilizados os comerciais leves movidos a diesel). Como os dados são crescentes até o ano de 2010, logo o setor sucroenergético esteve com números ainda mais expressivos, já que 92\% em 2009 eram carros flex fuel. Esses dados permitem observar a consolidação no mercado nacional de veículos flex fuel.

De acordo com a Anfavea (2010), a indústria automotiva já registrou a marca de 10 milhões de carros flex produzidos no país desde 2003, quando a tecnologia chegou. Com isso, os 
veículos movidos a etanol, à gasolina ou à mistura de ambos os combustíveis obtiveram em 2009 40\% de participação na frota nacional de automóveis leves do ciclo Otto (movidos à gasolina, etanol e veículos flex). Dentre esse cenário, cabe ainda destacar, segundo Neves et al (2009), que o mercado interno de etanol anidro movimentou um faturamento na ordem de US\$ 2.972,89 milhões com a venda de 6,48 bilhões de litros em 2008. O consumo no Brasil destina-se à mistura à gasolina, atualmente, na proporção de $25 \%$. Entretanto, devido ao aumento do consumo do etanol hidratado frente à gasolina aditivada com o etanol anidro (gasolina C), e em função do aumento dos carros flex fuel, esse consumo de etanol anidro nas usinas/destilaria produtoras tem diminuído nos últimos anos.

Nesse contexto, deve-se considerar os esforços que as usinas/destilarias, inclusive os fornecedores de cana, máquinas, equipamentos e insumos, tiveram de realizar para se adaptar a um novo ambiente de mercado, cujo uso da cana como matéria-prima para fabricação do etanol anidro ou hidratado passou a demonstrar sua retomada no crescimento da demanda no mercado interno.

A demanda por combustíveis, tal como apontado pela EPE (2009, p. 06), apresentou sua projeção por etanol hidratado, para o período de 2008 a 2017, na ordem de 53,2 bilhões de litros somente no mercado nacional. Essa estimativa condiciona-se pelo sucesso obtido nas vendas dos veículos flex, como visto na Tabela 2 anteriormente, tendo atingido 2,6 milhões de unidades em 2009.

Segundo os estudos da EPE (2009, p. 07-08), para o ano de 2017 projeta-se um número de 37,1 milhões de frota de veículos leves. Estima-se que a produção na indústria automobilística seja de 95\% veículos flex, uma vez que sua ascendência revela que, a partir de 2003, a participação desta categoria nas vendas no mercado interno tem aumentado exponencialmente, indo de 3\% em 2003, para 22\% em 2004, 53\% em 2005, 82\% em 2006 e 91,3\% em 2007. Admitida a tendência de consolidação desta categoria no mercado automotivo, considerando que apenas os automóveis importados e os de topo de linha são veículos dedicados à gasolina, correspondendo algo em torno de 5\% das vendas, restam, portanto, 95\% na modalidade flex fuel. Ou seja, não haverá venda de automóveis movidos unicamente a etanol no período de projeção do presente cenário para o ano de 2017. Sob esse aspecto, o perfil da frota por combustível dentre os anos de 2008 a 2017 demonstra a 
predominância por veículos flex, tal como pode ser observado na Tabela 3:

Tabela 3 - Perfil da frota (veículos leves) por tipo de combustível (2008 x 2017)

\begin{tabular}{|c|c|c|}
\hline Discriminação & 2008 & 2017 \\
\hline Gasolina & $63,4 \%$ & $24,8 \%$ \\
\hline Etanol & $7,0 \%$ & $1,6 \%$ \\
\hline Flex fuel & $29,6 \%$ & $73,6 \%$ \\
\hline
\end{tabular}

Fonte: EPE (2009, p. 08).

Uma vez estimada a frota para 37,1 milhões de veículos leves, compreende-se que desse montante 73,6\% serão veículos flex percorrendo todo país, oferecendo ao consumidor final no momento do abastecimento a autonomia decisória por qual combustível abastecer. Estima-se que $75,51 \%$ da energia consumida pelos veículos leves flex fuel foram supridos pelo etanol hidratado no ano de 2007, esse percentual foi obtido com base nos dados históricos de consumo da gasolina C, informados pela ANP, e pela produção de etanol (MAPA, 2010, p. 18).

Comparando-se a demanda total de etanol (carburante, exportação e outros usos) estimada pela EPE (2009, p. 40), com as projeções de produção do MAPA e da UNICA entre um período de 2007 a 2017, é possível notar que as projeções de oferta respectivamente estão entre 55 e 54 bilhões de litros, aquém da estimativa de demanda pela EPE, que se encontra em sua totalidade na ordem dos 64 bilhões de litros para o ano de 2017, sinalizando no longo prazo a necessidade por uma expansão da capacidade industrial brasileira, e certamente sua implicância será em preços, dado que a demanda será maior que a oferta. Já no curto prazo, os estudos da EPE (2009, p. 40) demonstram que já há diferenças entre demanda e oferta no período analisado, conforme ilustra o gráfico a seguir. 


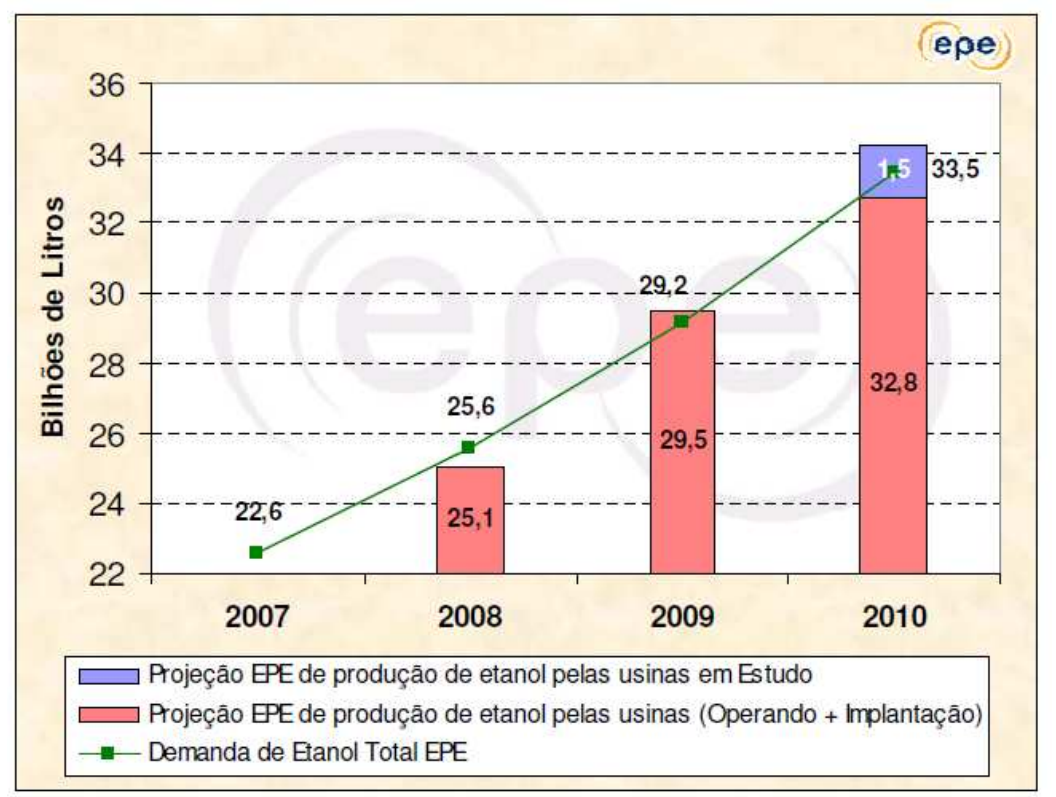

Gráfico 2 - Projeções de demanda total e da capacidade industrial de produção de etanol Fonte: EPE (2009, p. 40).

Apesar da diferença da demanda de etanol total ser menos que $2 \%$ da produção total no ano de 2009, esta poderá ser suprida por mudanças no direcionamento do uso da cana-de-açúcar para a produção do açúcar, conforme a demanda específica de cada mercado.

De acordo com o EPE (2009, p. 40-41), o etanol também tem servido como matéria-prima à indústria petroquímica no Brasil para produção de eteno e, assim, de produtos petroquímicos (como as resinas termoplásticas). Contudo, é uma matéria-prima que pode determinar se o uso será a partir da nafta ou então a partir da rota alcoolquímica, na aquisição de etanol, uma vez que compete diretamente com os preços do petróleo.

Segundo Bosco (2008, p. 21), a oferta de nafta crescerá, mas não de modo satisfatório a atender a demanda para produção de resinas termoplásticas. Porém, com o aumento sucessivo do preço do petróleo e a busca por novos insumos ambientalmente sustentáveis, surge a motivação de algumas empresas petroquímicas para a utilização do etanol como matériaprima. Na Tabela 4 são apresentados os principais projetos de implantação de unidades produtoras de resinas termoplásticas a partir de etanol. 
Tabela 4 - Projetos para produção de resinas termoplásticas a partir de etanol

\begin{tabular}{|c|c|c|c|c|c|}
\hline Empresa & Produto & $\begin{array}{c}\text { Capacidade } \\
\quad(103 t)\end{array}$ & Operação & Local & $\begin{array}{c}\text { Consumo } \\
\text { de etanol } \\
(\mathbf{1 0 6})\end{array}$ \\
\hline \multirow{2}{*}{ Braskem } & Polietileno & 200 & 2010 & Triunfo/RS & 500 \\
\hline & ETBE & 200 & 2012 & SP & 600 \\
\hline Dow/Crystalsev & $\begin{array}{l}\text { Polietileno de Baixa Densidade } \\
\text { Linear }\end{array}$ & 350 & 2011 & n. d. & 700 \\
\hline Soldvay/Copersucar & Ethyl Tertiary-Butyl Ether & 60 & 2010 & $\begin{array}{c}\text { Santo } \\
\text { André/SP }\end{array}$ & 150 \\
\hline
\end{tabular}

Fonte: EPE (2009, p. 12).

Com base nos dados da Tabela 4, estima-se que a demanda de etanol para a produção de polímeros na indústria alcoolquímica no Brasil será em torno de 500 milhões de litros em 2010, e há projeções conforme dados da $\operatorname{EPE~(2009,~p.~22)~de~1,95~bilhões~de~litros~no~}$ período compreendido entre 2011 e 2017. Este tipo de mercado é conhecido como produtos não energéticos do petróleo, que recentemente tem o etanol como matéria-prima substituta da nafta. Os produtos não energéticos são utilizados para outros fins que não o de combustível carburante. Vale ressaltar, conforme os estudos do MAPA (2005), que se as perspectivas de crescimento da demanda interna de etanol elevar, por conta da expansão dos veículos flex, aparentemente não haverá problemas em relação à distribuição do combustível. Isso se deve ao fato de que o maior mercado consumidor do combustível está localizado na região CentroSul do país, onde estão situados a grande maioria das unidades produtoras de etanol e os novos projetos em implantação. No entanto, a infraestrutura já existente no país em termos de produtores, centros coletadores de etanol, armazéns, bases de distribuição, postos de revenda e meios de transporte precisam estar coordenados com a capacidade no suprimento do combustível etanol, entre os diversos agentes da cadeia, em função da prospecção da demanda futura.

Por outro lado, há a perspectiva de aumento de produtividade de etanol, e esta dependerá das expectativas do setor sucroenergético, tais como aquelas relacionadas ao preço internacional de açúcar e preços de etanol no mercado interno, perspectivas do mercado internacional de etanol, usos alternativos, além do flex fuel no mercado brasileiro. Diante de uma perspectiva de aumento da produtividade e redução de custos de produção por meio de ganhos tecnológicos e escala produtiva, os estudos da EPE (2009) apontam que o preço do etanol ao consumidor deverá permanecer nos patamares realizados atualmente. Porém, é importante ressalvar que uma variabilidade em torno do patamar atual de preço pode ocorrer em função da sazonalidade anual do produto, dado que a disparidade entre oferta e demanda para o ano 
de 2009 é de $2 \%$. Isso permite entender que, em períodos de safra: maior oferta e preços menores; já em períodos de entressafra: menor oferta e preços maiores.

Decorrente disso, os estudos não preveem com precisão a elevação na produtividade de etanol frente à demanda sinalizada para o futuro, por conta dos efeitos sazonais, cotação do açúcar e dos usos alternativos que a cana-de-açúcar tem proporcionado atualmente. Por essa razão, para atender mercados internos e externos, admite-se a possibilidade de ocasionar uma situação de escassez temporária e, por conseguinte, uma elevação nos preços do etanol. O sucesso do flex e os usos alternativos, os quais serão vistos mais à frente, promovem um cenário de demanda elevada pela matéria-prima cana-de-açúcar, oferecendo ao setor desafios de produtividade e expansão agrícola como alternativas de superação competitiva pelo etanol hidratado.

Nota-se, portanto, que o mercado do combustível etanol se consolidou a partir dos incentivos promovidos pelo Proálcool, e somente a partir da tecnologia flex acrescida da tecnologia nos usos alternativos (por exemplo: eteno e farneceno), que foi o que redesenhou um quadro de demanda promissora por cana-de-açúcar. Ambas as tecnologias têm projetado, atualmente, um horizonte promissor, mas, até o presente momento, é a frota verde de veículos leves no país (flex) que desperta como sendo o principal divisor competitivo no uso da principal matéria-prima, cana-de-açúcar, na hora de formar preços no mercado do etanol hidratado.

Nos estudos sobre a projeção de demanda de etanol carburante no país, associado com o crescente incremento da frota flex fuel brasileira, estima-se que:

Nesse mercado, o combustível etanol irá demandar cerca de 55 bilhões de litros até 2020, salvo desequilíbrio no preço do etanol versus o preço da gasolina; há também o potencial de demanda desse combustível etanol no mercado externo de 39 bilhões de litros, por conta de legislação que requer a adição de etanol à gasolina (alguns países, a exemplo dos Estados Unidos, poderão recorrer à importação, caso novas rotas de produção não se concretizem). (MARQUES, 2010, p. 04).

Em relação à demanda do etanol como insumo para a alcoolquímica, no fabrico de eteno entre outros, Marques (2010, p. 73) alega que "há um potencial desse mercado alcançar uma demanda de cerca de 7 bilhões de litros, além da necessidade por açúcar, sobre o qual irá demandar 40 milhões de toneladas para o período projetado." Ainda segundo o autor, ao considerar que o Brasil responde por cerca de 2,8\% no ranking da produção mundial de eteno, fica claro quanto é significativo o potencial da demanda pela matéria-prima cana-de-açúcar. 
Cabe enfatizar a possibilidade de outro uso alternativo do etanol para produção de farneceno, sabe-se que essa tecnologia permite obter o diesel a partir da cana-de-açúcar. Assumindo que o consumo interno de diesel foi da ordem de 44,3 bilhões de litros no ano de 2009, e que no mundo é em torno de 1,25 trilhões de litros por ano, conforme dados da ANP (2010), estimase que há um cenário ainda mais promissor proporcionado para a matéria-prima cana-deaçúcar.

Alinhados a essas estimativas de demanda, dados do Ministério de Minas e Energia revelam que com a prospecção do aumento da demanda por cana-de-açúcar como matéria-prima para produção de açúcar, etanol e para usos alternativos (produção de eteno e farneceno), as áreas de expansão da cana-de-açúcar passariam dos 6,5 milhões de hectares plantados, para 21,5 milhões de hectares plantados até 2025, para atender mercados internos e externos.

\subsection{Caracterização da oferta do combustível etanol no Brasil}

Como visto anteriormente, a atuação governamental brasileira, no setor, Proálcool, foi significativa para a demarcação do contexto produtivo do combustível etanol no país. É pertinente enfatizar que a cadeia produtiva do etanol é também conhecida como cadeia produtiva sucroenergética. Nela há participação de órgãos ligados ao governo como: o Ministério da Agricultura, Pecuária e Abastecimento (MAPA), e a Agência Nacional do Petróleo (ANP). O MAPA é responsável pelo acompanhamento das fases agrícola e industrial da produção do etanol, enquanto à ANP competem às fases de distribuição e consumo do combustível, e tem por finalidade promover a regulação, a contratação e a fiscalização das atividades econômicas integrantes da indústria do petróleo, do gás natural e dos biocombustíveis. Dentre as atribuições da ANP destacam-se a de programar a política nacional de petróleo, gás natural e biocombustíveis, contida na política energética nacional. Além disso, a agência deve procurar enfatizar a garantia do suprimento desses produtos em todo o território nacional com o objetivo de proteger os interesses dos consumidores quanto a preço, qualidade e oferta de produtos. Outra instituição relevante para o mercado do etanol é a Superintendência de Abastecimento (SAB), ligada à ANP, sua responsabilidade é consolidar e atualizar a regulação do abastecimento nacional de combustíveis, bem como assegurar a efetivação de atribuições legais da agência conforme políticas de governo e transformações ocorridas no mercado. A SAB é a responsável por autorizar as atividades de distribuição de 
combustíveis de revendas varejistas de combustíveis automotivos e de Gás Liquefeito de Petróleo (GLP), Transportadores Revendedores Retalhistas (TRR) e a importação e exportação de combustíveis.

Identificado o programa e os principais órgãos do governo ligados à cadeia produtiva do etanol, cabe agora contemplar a lógica de encadeamento das operações, como forma de definir a produção que o produtor deverá seguir, ou seja, que proporção define o ponto de decisão entre ter de produzir etanol ou açúcar. O ponto que delimita o fator de decisão entre ter de produzir açúcar ou etanol, conforme Nascimento et al (2010, p. 01-13), deve relacionar que para cada um quilograma de açúcar há possibilidade de serem produzidos 0,684 litros de etanol anidro e da eficiência típica de $90 \%$ para fermentação e de $98 \%$ para destilação tem de estimar a preço de indiferença do etanol anidro (Piea) em comparação ao preço do açúcar (Paç): ou seja, a equação equivale a Piea (EUA \$ / litro) = 1,67 * Paç (EUA \$ / kg), uma relação racional no ganho de eficiência produtiva. Segundo os autores, nessa equação, considera-se apenas o valor da sacarose, sem incluir os custos associados ao investimento e à operação da unidade produtora. Só faz sentido produzir etanol a preços superiores a tal preço. Naturalmente, essa relação física perde sentido em casos-limite. Por exemplo, quando o mercado de açúcar se satura e a possibilidade de reduzir a produção de etanol para produzir mais açúcar se torna pouco atrativa, já que os preços do açúcar tendem a baixar por excesso de oferta, o que comprometeria seus custos.

O uso de melaço (subproduto da produção de açúcar) na produção de etanol também permite uma análise similar, que favorece, nesse caso, o etanol, pois o preço do melaço é sempre inferior ao preço do açúcar. Entretanto, as disponibilidades de melaço são sempre determinadas pela produção de açúcar e podem ser consideradas limitadas pelas necessidades de produção de etanol. Com efeito, enquanto, com base no caldo direto, produzem-se mais de 80 litros de etanol por tonelada de cana, por meio do melaço esgotado, são produzidos cerca de 12 litros por tonelada de cana processada, além do açúcar fabricado. De todo modo, constata-se que, na maioria dos países latino-americanos com produção açucareira, o melaço poderia constituir uma fonte de etanol relevante e precursora para o atendimento das necessidades internas de combustível. Por exemplo, nos países centro-americanos, apenas com o uso do melaço disponível e sem cultivar um hectare adicional de cana, seria possível atender a $22 \%$ da demanda de etanol necessária para promover a introdução de $10 \%$ desse 
biocombustível na gasolina consumida, totalmente importada por esses países (HORTA, 2008, p. 55).

É pertinente enfatizar que a produção de etanol pode se basear, portanto, na fermentação tanto do caldo da cana direto quanto de misturas de caldo e melaço. No caso de produzir etanol a partir do caldo direto, as primeiras etapas do processo de fabricação, da recepção da cana ao tratamento inicial do caldo, são semelhantes ao processo de fabricação do açúcar, daí ser menos vantajoso pela lógica da equação referida anteriormente, por ser mais oneroso ao envolver mais procedimentos operacionais.

De acordo com Horta (2008, p. 80), num tratamento mais completo, o caldo passa pela calagem, aquecimento e decantação, assim como no processo do açúcar. E, uma vez tratado, o caldo é evaporado para ajustar sua concentração de açúcares e, eventualmente, é misturado com o melaço, dando origem ao mosto, uma solução açucarada e pronta para ser fermentada chegando ao seu destino produtivo final - etanol. Percebe-se que há uma avaliação de viabilidade na produção de etanol, porém há que se considerar a possibilidade de determinado produtor decidir pela produção se compromissos contratuais ou estratégias de mercado existirem. Deve-se considerar também a variação que os preços do açúcar tem apresentado atualmente e os interesses comerciais na exportação, e essa consideração só é possível devido à alta demanda no comércio internacional e aos preços futuros da commodities.

Sob as considerações de Marjotta-Maistro (2002, p. 52), o setor sucroenergético do Brasil possui uma flexibilidade na sua produção, permitindo uma composição de um mix diferenciado: ora pode produzir mais açúcar, ora mais etanol. Essa tática se intensifica até hoje nas mesas de negociações entre o destino e a quantidade que deve ser produzida, cabendo enfatizar que essa flexibilidade pode ser atenuada pelo parâmetro da equação citada acima, caso não haja acordos contratuais passados a ser cumpridos ou estratégias mercadológicas do produtor. Porém, essa flexibilidade mostra-se como um instrumento que possibilita aos produtores redirecionarem suas atividades frente aos sinais de mercado, ou seja, frente a possíveis ganhos com a produção de etanol ou de açúcar, que atualmente divide com outros usos que a cana-de-açúcar também oferece, sendo o caldo da cana propício para o fabrico do farneceno e o etanol, matéria-prima para o eteno. 
Dessa forma, as decisões relativas, o que e quanto produzir em cada safra, são tomadas com certa antecedência, sobretudo nas trades que comercializam o açúcar e o etanol, tendo em vista: a operacionalização da produção no mercado interno ou externo, a liquidez, a rentabilidade, os custos de produção, e custos de capital correspondentes aos investimentos produtivos realizados serem iguais ou superior aos resultados que seriam obtidos caso a matéria-prima se destinasse à fabricação de produtos alternativos. Assim, o processo de tomada de decisão sobre que destino produtivo terá a cana-de-açúcar corresponde às expectativas em relação ao preço e às quantidades demandadas de açúcar e de etanol, externa e interna, e futuramente, de maneira mais significativa, aos usos alternativos.

Desse modo, a oferta interna de etanol anidro e hidratado deve obedecer a um planejamento de longo prazo e atentar-se para a necessidade de abastecimento do produto, uma vez que a frota de carros movidos a etanol hidratado em circulação no país é de 3,5 milhões em 2009, conforme dados da Unica (2010). Nesse contexto, nota-se que a oferta de etanol estabelece alguns parâmetros decisórios de produção, como: equação do fator delimitador, acordos contratuais e estratégias mercadológicas. No entanto, há ainda que se considerar os preços comercializados da gasolina no mercado internacional e local, custos logísticos, custos de armazenagem, preços internacionais do açúcar, custo de oportunidade dos produtos alternativos e preço do melaço (que possibilita a produção de etanol a preços mais baixos). As condições de mercado seriam outro fator que promoveria a decisão de ofertar etanol, porém em bases competitivas se considerar que a liberalização de mercado permite a ocorrência das importações.

No que compete a valores quantitativos da produtividade anual de cana-de-açúcar, Horta (2008, p. 74) acrescenta que a produção é bastante influenciada pela variabilidade climática e pela região produtora, estando entre 50 t/ha e 100 t/ha (peso do colmo úmido), ficando a média brasileira em torno de 70 t/ha plantado, um valor comparável às melhores regiões produtoras em outros países. Na Região Centro-Sul do Brasil, onde se localiza a maior parte das usinas brasileiras, esses índices, segundo o autor, estão entre 78 t/ha e 80 t/ha, enquanto no Estado de São Paulo, principal produtor, situa-se na faixa de 80 t/ha a 85 t/ha, em ambos os casos considerando ciclo de cinco cortes. Já em relação à evolução da produção do etanol no mercado brasileiro, a Tabela 5, a seguir, permite avaliar o quanto ela vem evoluindo dentre as diversas regiões do país após a desregulamentação. 
Tabela 5 - Produção de etanol hidratado de 2000 a 2009 (mil m3)

\begin{tabular}{|c|c|c|c|c|c|c|c|c|c|c|c|}
\hline \multirow[t]{2}{*}{ Regiões e Estados } & \multicolumn{10}{|c|}{ Produção de etanol anidro e hidratado (mil m3) } & \multirow[t]{2}{*}{$10 / 09(\%$} \\
\hline & 2001 & 2002 & 2003 & 2004 & 2005 & 2006 & 2007 & 2008 & 2009 & 2010 & \\
\hline Brasil & $4.985,14$ & $5.548,63$ & $5.638,29$ & $6.788,47$ & $7.832,15$ & $9.851,38$ & & $\mathbf{1 7 . 5 5 6 , 2 8}$ & $19.089,27$ & $20.166,88$ & 5,65 \\
\hline Região Norte & 12,81 & 13,64 & 8,69 & 9,24 & 13,61 & 19,09 & 17,91 & 34,90 & 47,62 & 48,99 & 2,89 \\
\hline Acre & - & - & - & - & - & - & - & - & - & 1,49 & - \\
\hline Rondônia & - & - & - & - & - & - & - & - & 8,55 & 10,76 & 25,88 \\
\hline Amazonas & 1,85 & 3,89 & 4,38 & 4,67 & 6,01 & 5,65 & 8,26 & 7,96 & 4,74 & 7,14 & 50,66 \\
\hline Pará & 10,96 & 9,75 & 4,32 & 4,57 & 7,49 & 11,32 & 9,64 & 25,26 & 31,91 & 17,61 & $-44,81$ \\
\hline Tocantins & - & - & - & - & 0,11 & 2,13 & - & 1,68 & 2,42 & 11,99 & 396,27 \\
\hline Região Nordeste & 640,04 & 763,15 & 737,61 & 861,09 & $\mathbf{7 7 5 , 8 0}$ & 711,40 & 987,60 & $1.211,57$ & $1.284,18$ & 983,80 & $-23,39$ \\
\hline Maranhão & 9,38 & 6,22 & 5,61 & 8,72 & 11,08 & 20,26 & 50,15 & 60,44 & 58,75 & 39,12 & $-33,42$ \\
\hline Piauí & 13,17 & 11,60 & 4,35 & 4,33 & 5,83 & 13,95 & 9,53 & 11,42 & 5,15 & 2,39 & $-53,60$ \\
\hline Ceará & 1,19 & 0,98 & 0,32 & 0,15 & 1,02 & 1,00 & 0,57 & 6,90 & 10,76 & 4,04 & $-62,43$ \\
\hline Rio Grande do Norte & 29,82 & 66,25 & 31,71 & 37,44 & 39,14 & 28,60 & 35,44 & 46,77 & 82,36 & 49,30 & $-40,15$ \\
\hline Paraíba & 136,59 & 135,88 & 131,75 & 158,66 & 171,71 & 147,47 & 212,88 & 213,15 & 237,95 & 182,13 & $-23,46$ \\
\hline Pernambuco & 123,33 & 152,07 & 165,27 & 151,66 & 128,22 & 112,28 & 212,07 & 297,94 & 309,47 & 237,11 & $-23,38$ \\
\hline Alagoas & 278,63 & 344,89 & 351,10 & 447,87 & 361,04 & 328,90 & 399,25 & 494,34 & 421,62 & 330,25 & $-21,67$ \\
\hline Sergipe & 25,27 & 28,86 & 29,47 & 33,78 & 39,05 & 30,48 & 12,46 & 29,09 & 85,39 & 68,50 & $-19,78$ \\
\hline Bahia & 22,68 & 16,40 & 18,04 & 18,49 & 18,72 & 28,45 & 55,26 & 51,53 & 72,74 & 70,97 & $-2,42$ \\
\hline Região Sudeste & $3.102,00$ & $3.441,03$ & $3.320,67$ & $4.279,67$ & $5.115,17$ & $6.877,56$ & $9.875,79$ & $12.347,86$ & $12.915,91$ & 13.298,17 & 2,96 \\
\hline Minas Gerais & 193,43 & 261,14 & 400,27 & 429,32 & 525,88 & 691,18 & $1.167,92$ & $1.634,03$ & $1.793,39$ & $2.084,00$ & 16,20 \\
\hline Espírito Santo & 57,02 & 59,79 & 48,55 & 46,67 & 46,27 & 47,48 & 88,72 & 125,43 & 130,73 & 104,37 & $-20,16$ \\
\hline Rio de Janeiro & 38,91 & 62,19 & 65,17 & 101,65 & 84,08 & 59,52 & 93,32 & 89,20 & 102,86 & 69,87 & $-32,07$ \\
\hline São Paulo & $2.812,64$ & $3.057,92$ & $2.806,68$ & $3.702,04$ & $4.458,95$ & $6.079,38$ & $8.525,84$ & $10.499,20$ & $10.888,94$ & $11.039,93$ & 1,39 \\
\hline Região Sul & 581,65 & 578,33 & 729,49 & 760,64 & 656,29 & 864,81 & $1.563,79$ & $1.471,32$ & $1.528,92$ & $1.464,59$ & $-4,21$ \\
\hline Paraná & 576,34 & 571,92 & 723,44 & 755,82 & 652,95 & 859,31 & $1.556,79$ & $1.465,00$ & $1.526,46$ & $1.458,79$ & $-4,43$ \\
\hline Rio Grande do Sul & 5,31 & 6,41 & 6,05 & 4,82 & 3,34 & 5,50 & 7,00 & 6,32 & 2,46 & 5,81 & 135,98 \\
\hline Região Centro-Oeste & 648,64 & 752,48 & 841,82 & 877,83 & $1.271,28$ & $\mathbf{1 . 3 7 8 , 5 1}$ & $1.857,57$ & $2.490,64$ & $3.312,64$ & $4.371,33$ & 31,96 \\
\hline Mato Grosso do Sul & 168,67 & 211,58 & 252,44 & 239,99 & 401,83 & 437,40 & 659,43 & 709,03 & $1.088,88$ & $1.520,53$ & 39,64 \\
\hline Mato Grosso & 304,12 & 334,30 & 313,08 & 364,17 & 436,01 & 485,88 & 486,18 & 546,22 & 538,35 & 579,38 & 7,62 \\
\hline Goiás & 175,85 & 206,60 & 276,31 & 273,67 & 433,43 & 455,24 & 711,96 & $1.235,39$ & $1.685,42$ & $2.271,42$ & 34,77 \\
\hline
\end{tabular}

Fonte: ANP (2011) 
Evidencia-se que o etanol tem exercido um importante papel, dadas as circunstâncias estruturais formadas a partir do Proálcool até as tecnologias hoje estabelecidas nas indústrias, produtoras e automotivas (flex fuel). Observa-se pela Tabela 5 o aumento exponencial da produção de etanol hidratado dentre os anos de 2001 a 2010, e nota-se que a região sudeste foi a que mais se destacou no crescimento, 328,7\%. Esse volume de crescimento produtivo, 13,2 bilhões de litros de etanol hidratado, exige uma estrutura de abastecimento e distribuição que permita o fluxo dentre os principais agentes envolvidos nesse setor sucroenergético, tal como pode ser observado na Figura 4. 


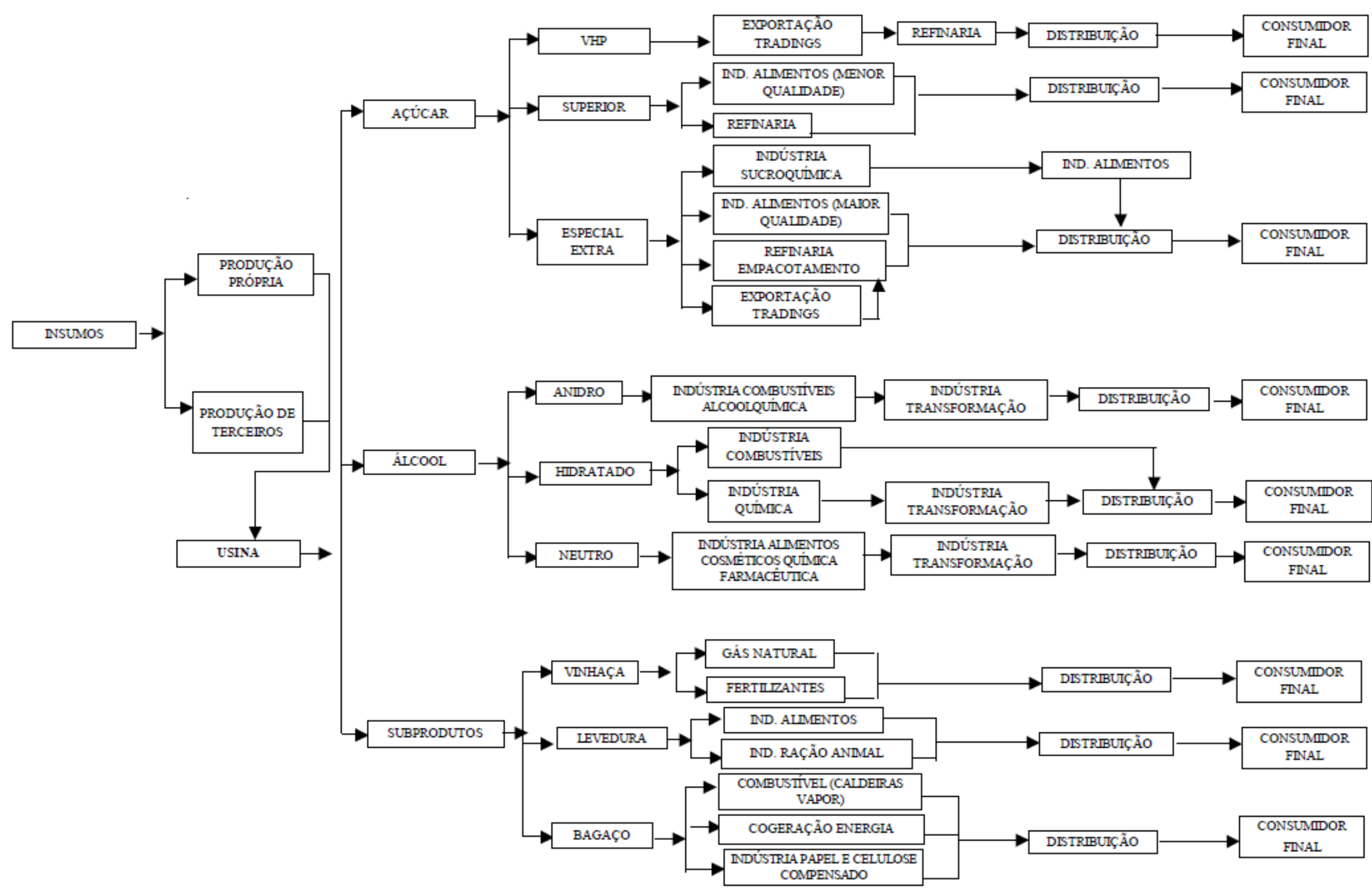

Figura 4 - Cadeia Produtiva Sucroenergética

Fonte: Waack; Neves (1998, p. 14). 
Nota-se que o etanol é estocado em tanques na própria usina que, posteriormente, o fornece para as distribuidoras de combustíveis ou indústria química. O etanol é enviado tanto para bases coletoras primárias como secundárias, ou seja, das bases primárias (produtores/refinaria), o combustível é transferido às bases secundárias e das bases secundárias (distribuidoras) é entregue aos postos combustíveis.

Na primeira etapa, até as bases primárias, o transporte é feito via transporte ferroviário ou rodoviário, sendo que para o etanol o modal rodoviário é o mais significativo, algo em torno de $70 \%$ do fornecimento, conforme Scandiffio (2005).

Nesse aspecto, observar a cadeia produtiva e contextualizar as bases primárias e secundárias são atividades pertinentes, pois reforça a hipótese de que o frete para a distribuição do etanol possui relação quanto a custos e estratégias de comercialização, e esta abordagem será retratada no capítulo seguinte. Deve-se destacar que tanto o etanol quanto o açúcar representam os principais produtos finais desta cadeia sucroenergética e atendem às diferentes indústrias como as de: gás natural, fertilizantes, alimentos, sucroquímica, refinaria, combustíveis, cosméticos, química farmacêutica, papel e celulose compensado etc.

De acordo com a Conab (2010), a projeção da oferta de etanol, com perspectiva de atendimento à demanda brasileira, parte da avaliação da produção nacional de cana destinada à indústria sucroenergética, que, na safra 2009/2010, processou 605 milhões de toneladas. Já a produção de etanol, no ano de 2010, alcançou 28 bilhões de litros, dos quais 8,1 bilhões são de etanol anidro e o restante hidratado (ANP, 2011).

Segundo a Conab (2010), a área plantada para a safra 2009/2010 foi de 8,1 milhões de hectares, com uma produtividade média de $82.103 \mathrm{~kg}$ de cana-de-açúcar por hectare. No entanto, há possibilidade de expansão dos plantios energéticos no país, visto que, segundo o EPE (2009), há 383 milhões de hectares aptos para a agricultura e pecuária, dos quais 220 são áreas de pastagens, 72 são utilizados para plantios permanentes ou anuais e 91 são áreas passíveis para a expansão da agricultura, desde que atendidos os dispositivos legais e normativos referentes ao uso e ocupação do solo. Em relação à capacidade industrial, a UNICA (2010) revela que o país dispõe de 421 usinas em operação até o ano de 2009. 
Dadas as características acerca da situação da produção sucroalcooleira apresentadas anteriormente, mostra-se necessário avaliar as projeções da oferta de etanol elaboradas por instituições nacionais. Nesse contexto, foram consideradas aquelas do MAPA e da UNICA. O MAPA elaborou um cenário de oferta de etanol até 2017, vislumbrando uma capacidade de produção agrícola e industrial apta a ofertar até 55,5 bilhões de litros de etanol, o que representaria um aumento superior a 113\% em relação à produção do ano de 2009 entre etanol anidro e hidratado, de 26 bilhões de litros. Conforme a Tabela 6, é possível constatar projeções de oferta de etanol até 2017. 
Tabela 6 - Valores de referência de oferta de etanol do MAPA (2006 x 2017)

\begin{tabular}{|c|c|c|c|c|c|c|c|c|c|c|c|c|c|}
\hline & & 2006 & 2007 & 2008 & 2009 & 2010 & 2011 & 2012 & 2013 & 2014 & 2015 & 2016 & 2017 \\
\hline Usinas em operação (ano anterior) & Unidades & 351 & 370 & 395 & 420 & 445 & 470 & 495 & 520 & 545 & 570 & 595 & 620 \\
\hline Capac. Instalada & t (milhão moag.) & 450 & 488 & 538 & 588 & 638 & 688 & 495 & 788 & 838 & 888 & 938 & 988 \\
\hline Prod. de açúcar & (milhões ton.) & 30,5 & 30,8 & 31,8 & 33,2 & 34,6 & 36 & 738 & 38,8 & 40,1 & 41,5 & 42,9 & 44,3 \\
\hline Prod. de etanol & (bilhões de litros) & 17,75 & 22,5 & 27,1 & 26,3 & 31,7 & 35,1 & 37,4 & 41,9 & 45,3 & 48,7 & 52,1 & 55,5 \\
\hline Novas Usinas & Unidades & 19 & 25 & 25 & 25 & 25 & 25 & 38,5 & 25 & 25 & 25 & 25 & 25 \\
\hline Inv. Ind. & t (milhãomoag.) & 38 & 50 & 50 & 50 & 50,0 & 50 & 25 & 50 & 50 & 50 & 50 & 50 \\
\hline Da nova capac. Ind. $(*)$ & US\$ (milhão) & 1.919 & 3.030 & 3.787 & 3.787 & 4.418 & 6.059 & 50 & 5.680 & 5.049 & 5.049 & 5.049 & 3.787 \\
\hline Da nova capac. acum. até o ano & US\$ (milhão) & 1.919 & 4.948 & 8.735 & 12.522 & 16.940 & 22.999 & 6.059 & 34.739 & 39.788 & 44.837 & 49.887 & 53.674 \\
\hline Da capac. em prod. & US\$ (milhão) & 102 & 371 & 961 & 1.948 & 3.646 & 6.132 & 29.058 & 15.262 & 20.903 & 27.166 & 34.109 & 41.595 \\
\hline Custo da prod. de cana-de-açúcar & US\$ (milhão) & 18,9 & 65,8 & 166 & 326 & 597 & 988 & 10.317 & 2.400 & 3.183 & 4.019 & 4.911 & 5.854 \\
\hline Açúcar produzido pelas novas ind. & t (milhão) & - & - & 1 & 1,39 & 1,39 & 1,39 & 1.642 & 1,39 & 1,39 & 1,39 & 1,39 & 1,39 \\
\hline Etanol produzido pelas novas ind. & 1 (bilhão) & 0,16 & 0,59 & 3,40 & 3,40 & 3,40 & 3,40 & 1,39 & 3,40 & 3,40 & 3,40 & 3,40 & 3,40 \\
\hline
\end{tabular}

* é o valor do investimento da capacidade industrial a ser instalada.

Fonte: EPE (2008 apud MAPA, 2009, p. 36). 
De acordo com os dados anteriores, verifica-se que as projeções apontadas pelo MAPA partem das premissas referentes ao ATR (Açúcar Total Recuperável) de 146 kg/t de cana; $1,72 \mathrm{~kg}$ de ATR para produzir um litro de etanol; entrada em operação de 25 novas usinas por ano, com capacidade média anual de dois milhões de toneladas de cana processada, sendo $80 \%$ utilizados para a produção de etanol. Ou seja, há uma predominância entre ter que produzir etanol ao invés do açúcar, e ainda o MAPA desconsidera a possibilidade de a cana servir a outros usos com o eteno e o farneceno. Sob esse cenário apontado pelo MAPA, a UNICA traçou suas estimativas em relação à oferta de etanol para as safras de 2015/16 e 2020/21, que são mostradas na Tabela 7.

Tabela 7 - Resumo das Estimativas da ÚNICA

\begin{tabular}{lcc}
\hline & $\mathbf{2 0 1 5 / 1 6}$ & $\mathbf{2 0 2 0 / 2 1}$ \\
\hline Produção de cana-de-açúcar (milhões t) & 829 & 1.038 \\
Área cultivada (milhões ha) & 11,4 & 13,9 \\
Açúcar (milhões t) & 41,3 & 45 \\
Consumo interno (açúcar) & 11,4 & 12,1 \\
Excedente para exportação & 29,9 & 32,9 \\
Etanol (bilhões de litros) & $\mathbf{4 6 , 9}$ & $\mathbf{6 5 , 3}$ \\
Consumo interno (etanol) & 34,6 & 49,6 \\
Excedente para exportação & 12,3 & 15,7 \\
\hline
\end{tabular}

Fonte: EPE (2008 apud UNICA, 2008, p. 37).

A Tabela 7 revela que a expansão da produção brasileira de etanol estimada pela UNICA acontecerá de acordo com o consumo nos mercados carburante interno e externo, adicionados aos volumes projetados para outros usos (não carburante), representando o total requerido ao setor produtivo. Dessa forma, o MAPA prospecta uma produção em torno de 55,5 bilhões de litros de etanol para o ano de 2017, ao passo que a UNICA estima 65 bilhões de litros para 2021, sendo maior devido às considerações do uso do etanol para outros fins que não o carburante, daí a importância de compreender que fins tecnológicos há a partir do etanol, pois eles podem comprimir a oferta se tais possibilidades de uso serem significativas, uma vez que a cana-de-açúcar permite opções diversas de produção que não somente o açúcar e o etanol.

\subsection{Etanol: tecnologia e usos alternativos}

Como já observado, as projeções da demanda por combustível etanol indicam um setor promissor e dinâmico, pois também vem evoluindo e se renovando continuamente com o emprego da tecnologia, tal como a flex fuel. Esforços tecnológicos na cadeia sucroenergética 
concentraram-se no final da década de 1980 e na década de 1990, sobretudo na fase pósdesregulamentação do setor, porém as pesquisas realizadas nos anos anteriores também deram sustentação à competitividade. Os maiores desafios foram na ordem econômica e institucional, que demandaram novas capacitações tecnológicas e de governança, aumentando a complexidade das soluções tecnológicas requeridas para a sustentação da competitividade setorial.

Este tópico irá abordar a tecnologia empregada no processo produtivo do etanol, e posteriormente contracenar com seus usos alternativos, sejam eles partidos pela disputa da matéria-prima cana ou pelo produto etanol. No que compete às tecnologias empregadas no processo de produção de etanol, elas podem ser vistas sob duas gerações. O processo de primeira geração refere-se à cana-de-açúcar, ou seja, aquele gerado pelo processamento industrial do colmo, ou seja, do caule da planta. No caule há açúcares disponíveis para sofrerem o processo de fermentação e, assim, consegue-se a obtenção do etanol. Já o de segunda geração é aquele obtido por meio da fermentação de açúcares presentes no bagaço e na palha da cana - lignocelulósicos, esses ainda não estão disponíveis no mercado, pois estão em fase de pesquisa para a busca de um processo industrial economicamente viável. Assim, todo o etanol encontrado nos postos de revenda é oriundo da primeira geração.

Para Seabra (2008), a produção do etanol no país é baseada na fermentação tanto do caldo da cana, como de misturas de caldo e melaço, o que permite uma grande sinergia na produção de açúcar e etanol nas usinas brasileiras. As primeiras etapas do processo de fabricação, da recepção da cana ao tratamento inicial do caldo, são semelhantes ao processo de fabricação do açúcar, tido como o processo de primeira geração, viável e disponível no mercado como etanol anidro e hidratado. Tal processo, segundo o autor, inicia-se com:

O caldo que passa pela calagem, aquecimento e decantação, assim como no processo do açúcar. Uma vez tratado, o caldo é evaporado e misturado com o mel, dando origem ao mosto. O mosto segue para as dornas de fermentação, onde é adicionado de leveduras (saccharomyces cerevisae) e fermentado por um período de 6 a 12 horas. O processo de fermentação mais utilizado nas destilarias do Brasil é o Melle-Boinot, cuja característica principal é a recuperação das leveduras por meio da centrifugação do vinho (mosto fermentado). Após a fermentação, o vinho (com uma concentração de 7 a 10\% de etanol) é centrifugado, para a recuperação das leveduras, e enviado para as colunas de destilação. Na destilação, o etanol é recuperado com auxílio de sete colunas distribuídas em quatro troncos: destilação propriamente dita, retificação, desidratação e debenzolagem. (SEABRA, 2008, p. 37).

O etanol produzido pode ser diretamente armazenado nos tanques, ou enviado para a desidratação, para a produção do etanol anidro. E tanto nesta etapa quanto na etapa anterior, a 
indústria pode se beneficiar do poder calorífico no processo de desidratação para geração de energia elétrica.

Ressalta-se, ainda, que uma simples destilação não é o suficiente para o etanol hidratadoPois, é uma mistura azeotrópica (no ponto de ebulição não ocorre nenhuma alteração). A tecnologia mais utilizada no Brasil é a desidratação por intermédio da adição do ciclohexano, formando uma mistura azeotrópica ternária, com ponto de ebulição inferior ao do etanol anidro. $\mathrm{Na}$ desidratação, o ciclohexano é adicionado, e o etanol anidro é retirado no fundo, com aproximadamente $99,7^{\circ} \mathrm{GL}$; e a mistura ternária retirada é condensada e decantada, e a parte rica em água é enviada à coluna de recuperação de ciclohexano. (SEABRA, 2008, p. 37-38).

O diagrama de fluxo do processo de produção do etanol é mostrado na Figura 5 a seguir:

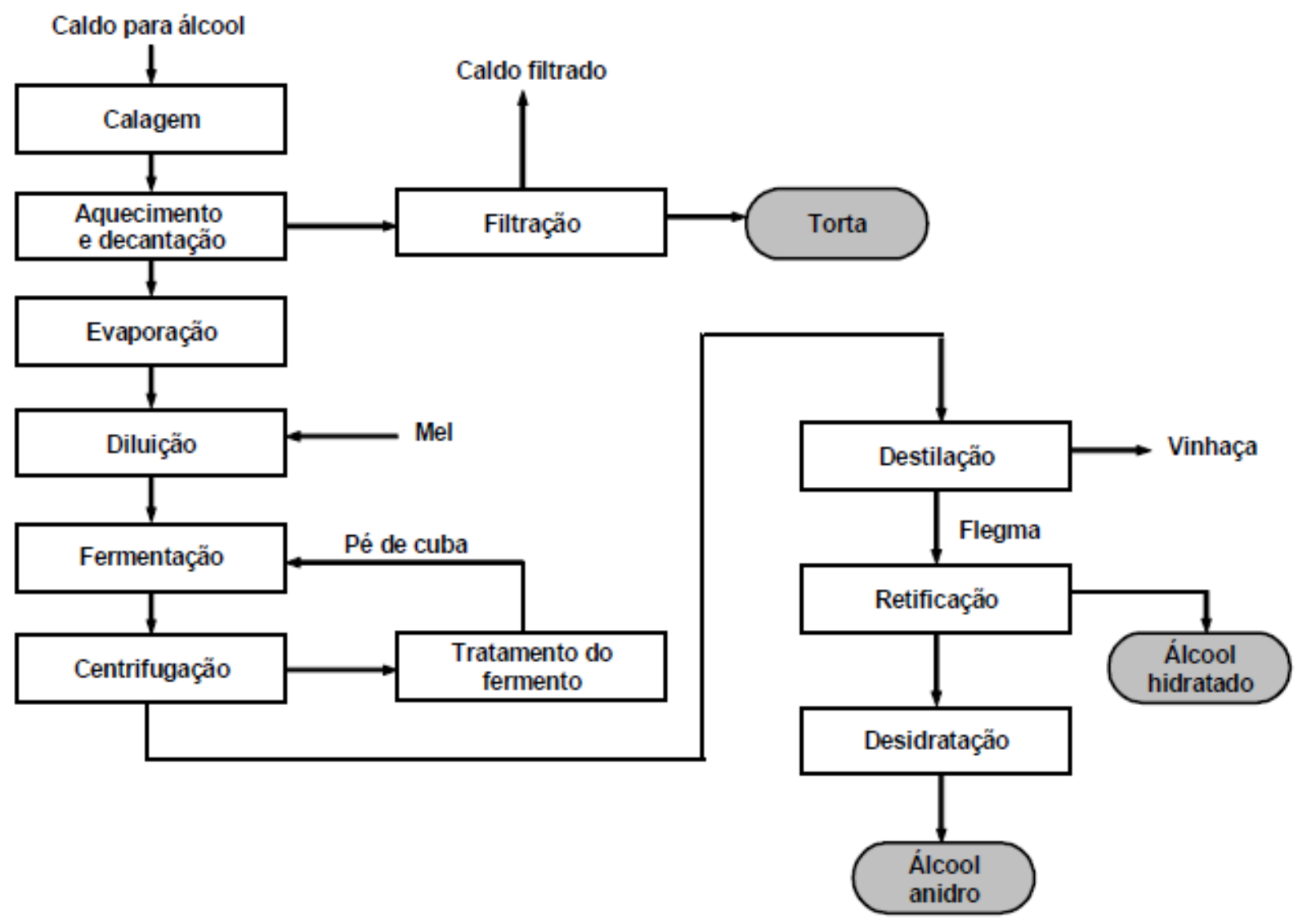

Figura 5 - Diagrama do fluxo da fabricação do etanol Fonte: Seabra (2008, p. 39).

Tal fato também é compreendido por Bernardo Neto (2009, p. 46), o qual reforça que a principal composição obtida na primeira geração se dá pelo reagente do processo fermentativo conhecido por mosto. E, na Figura 5, observa-se a etapa de diluição, composta por um caldo 
de cana tratado, com concentração ideal para o bom desempenho do processo fermentativo, controlada por intermédio da adição de xarope e/ou água.

Portanto, essa tecnologia é conhecida como tecnologia de primeira geração de obtenção de etanol e possui, segundo Bernardo Neto (2009, p. 47), um rendimento energético de aproximadamente $30 \%$ de toda a energia contida na cana-de-açúcar, devido ao aproveitamento apenas da sacarose contida na cana-de-açúcar. Ou seja, não há aproveitamento do bagaço e da palha da cana-de-açúcar para produção de etanol, pois eles são considerados resíduos e, por isso, são reutilizados por alguns produtores na cogeração de energia elétrica e adubação do solo. E são as tecnologias empregadas nesses resíduos que demarcam a segunda geração na produção do etanol. Entretanto, reprocessar os resíduos é uma tecnologia cara e inviável se comparada aos investimentos e agregação de uma nova fonte de energia a elétrica.

Entende-se que os progressos tecnológicos na cadeia produtiva do etanol impactam diretamente na redução dos custos da produção do etanol e no aumento da produtividade, sendo alcançadas, por meio dos esforços da eficiência agrícola dos cultivares, variedades da cana e melhoria na turbidez do caldo. Assim, no que diz respeito à parte industrial da produção do etanol relacionada à segunda geração, seja pelas plataformas termoquímica ou bioquímica, estas plataformas são compreendidas como alternativas tecnológicas de elevado investimento.

Portanto, a segunda geração da produção do etanol não se tem apresentado aderente à viabilidade econômica se comparada ao reaproveitamento para cogeração de energia elétrica e adubação do solo pelos resíduos reaproveitados na produção de primeira geração. Assim, o Brasil apresenta a plataforma produtiva convencional na produção do etanol (prevalece a produção do etanol pela primeira geração), feita por meio da fermentação de materiais ricos em amido ou sacarose, que em seu processo pode ainda agregar a geração de energia elétrica por intermédio da cogeração com ciclos a vapor (opção atualmente comercial).

Observado que a produção de etanol é viável pela primeira geração, cabe enfatizar que seus esforços em ganhos produtivos e de redução de custos devem estar concentrados no setor agrícola por meio da colheita mecanizada e melhoria genética da muda. E apenas uma parte 
dos esforços deve ser promovida na área industrial, que atualmente se revela por meio da tecnologia de dosagens de polímero que proporciona maior velocidade de sedimentação, compactação e redução do volume de lodo, produção do lodo com maior filtrabilidade, redução das perdas de sacarose e, sobretudo, melhoria na turbidez do caldo (BERNARDO NETO, 2009, p. 51-52). Ou seja, na fase agrícola há maior possibilidade de alcance produtivo e, por conseguinte, de redução nos custos de produção de etanol.

A busca por ganhos produtivos potencializando a tecnologia, seja no setor agrícola, seja no industrial, tem por objetivo atender à projeção de demanda do uso do combustível etanol, uma vez destacado como uma alternativa viável economicamente às montadoras e também à redução nas emissões de carbono. Ressalta-se aqui que o etanol anidro, ou Etanol Anidro Carburante (EAC), é praticamente puro, com um teor alcoólico entre 99,3\% e 99,8\%, a $20^{\circ} \mathrm{C}$, e é utilizado como um aditivo que aumenta o teor de oxigenados na gasolina - no Brasil a mistura é atualmente de até $25 \%$. Já em relação ao etanol hidratado, ou Etanol Hidratado Carburante (EHC), este contém um teor alcoólico entre $92,6 \%$ e $93,8 \%$, a $20^{\circ} \mathrm{C}$, sendo o restante água, por isso o seu nome "hidratado", e é utilizado diretamente nos automóveis flex, conhecidos como carros $100 \%$ movidos a etanol, gasolina C ou mistura de ambos (COPERSUCAR, 2003).

Sob o ponto de vista das reduções das emissões tóxicas e de gases de efeito estufa, o uso do combustível oriundo da biomassa supera-se se comparado aos derivados do petróleo. Percebese que a biomassa possui duas fontes importantes para o ser humano, a primeira se dá pelo suprimento alimentar, e a segunda por ser continuamente renovável, no caso do etanol. O combustível etanol tem sua aderência ao princípio do funcionamento do motor de combustão. O motor de combustão interna está onipresente em várias atividades, seja no meio urbano, seja no rural, e constitui-se numa das mais importantes máquinas transformadoras de energia empregadas pela humanidade ao longo de sua história.

Machado (2008, p. 08) aponta que, no Brasil, nos últimos vinte anos, os motores de combustão interna alcançaram um grau de evolução que, até o início da década de oitenta, não se apresentava como fundamental para sua utilização. A grande contribuição da indústria brasileira, para a evolução dos motores, foi a efetiva afirmação dos combustíveis não convencionais, principalmente originários da biomassa, como fonte energética. Assim, o 
combustível etanol é uma alternativa interessante, pois, além de ser uma fonte renovável, possui uma característica importante por ser um tipo de combustível oxigenado, o que representa ser um elemento redutor das emissões de particulados pelos motores de ignição por compressão.

As tecnologias empregadas no desenvolvimento do etanol são notórias no setor sucroenergético. Por conseguinte, estabelece-se também um avanço nos motores por empresas sistemistas e também pelas próprias montadoras, dentre os quais se têm os motores de ignição por centelha, também chamados de motor Otto (em homenagem ao seu idealizador pelo engenheiro alemão Nikolaus Otto, em 1876, conforme Machado, 2008). Esse motor é usado em veículos leves e recebeu várias adaptações ou melhorias tecnológicas a fim de que o uso pudesse atender ao uso de dois tipos de combustíveis. Van Gerpen e Knothe (2006) explicam que os motores de ignição por centelha queimam uma mistura de ar e combustível, química e corretamente dosada, comprimida e que somente entra em combustão pela ação de uma faísca elétrica. Em seguida, as condições de pressão alcançadas na câmara de combustão elevam a temperatura do ar a valores suficientes para promover a autoignição do combustível que é injetado em alta velocidade e, finamente, pulverizado nesta atmosfera.

Similarmente, Machado (2008, p. 09-10) destaca que o combustível é misturado com o ar no sistema de admissão, formando uma mistura homogênea que, após ser comprimida, entra em combustão pela ação de uma descarga elétrica. Uma chama se desenvolve desde o foco inicial criado e se propaga por intermédio do cilindro até as paredes da câmara de combustão. Ao atingir as paredes, a chama se extingue, tanto pela transferência de calor para as paredes como pela extinção das espécies químicas ativas. É possível ainda notar, segundo o autor, que o motor de Ignição por Centelha Elétrica (ICE), em sua autoignição, é uma combustão anormal, chamada de detonação, e que, devido às altas pressões e temperaturas geradas, pode ocasionar danos ao motor. Já no motor Diesel, como o combustível é injetado no cilindro no interior da massa de ar com pressão e temperatura previamente elevadas, ocorre a autoignição de porções da mistura resultante da injeção e da vaporização do combustível no ar quente.

Dessa forma, é possível perceber a diferença entre os processos de combustão de ignição por centelha e dos motores diesel, em que: no primeiro existe uma chama freqüente propagandose por meio de uma mistura de ar e combustível pré-formada, enquanto no diesel, o que se 
identifica é uma difusão da chama, sem pré-mistura. Assim, fica evidente que o combustível etanol tem aderência melhor no motor ICE do que no motor Diesel. Porém a inserção de uma inovação ou melhoria está em estudo para que o motor Diesel também seja passível ao uso do combustível etanol, e sendo confirmada a demanda por etanol pode elevar-se para o mercado carburante do diesel.

Contudo, o uso do etanol como combustível para motores de ciclo Otto ou ICE, em substituição à gasolina, está consolidado no Brasil e ganha, agora, projeção mundial com os diversos acordos de cooperação comercial e tecnológica com outros países, por ser uma tecnologia que se acopla ao motor de ignição por centelha. E, após o incremento tecnológico dado pelo sensor de oxigênio (que nada mais é que uma melhoria tecnológica decorrente da injeção eletrônica) proporcionou que o etanol pudesse ser então utilizado no motor a gasolina.

Para Machado (2008, p. 03), a combustão nos motores de ignição por centelha é uma condição ímpar para o funcionamento do combustível etanol, em que a injeção do combustível na câmara identifica o teor do combustível para que a faísca seja acionada nas condições suficientes de sustentação da queima contínua. Sendo tal processo suscetível à viscosidade do combustível e às pressões de trabalho do motor que, conjugados tais fatores, determinam a forma com que o combustível penetra na câmara de combustão. $\mathrm{O}$ autor ainda ressalta que, as características do jato emergente do bico injetor que determinam a eficiência do processo de queima, estabelecendo por sua vez: condições de liberação da energia do combustível; desenvolvimento de potência e torque; regime potencial de rotações do motor; e, os possíveis teores de elementos nocivos que estarão presentes nos gases de exaustão. Tal eficiência se diferencia se tratar de um motor com combustível a gasolina, etanol ou em determinado teor de mistura. Ou seja, o fator determinante para definição do combustível em uso é a eficiência e a qualidade da combustão, esses dados são obtidos pela sonda lambda, e posteriormente ocorrerá a adaptação automática do funcionamento do motor, sem necessidade de qualquer intervenção de quem está ao volante do veículo.

Em conformidade, Erokhin et al (1986, p. 42-49) destacam que uma das mais importantes características de um combustível é o seu calor de combustão, que é definido como sendo a quantidade de calor liberado em condições de combustão total de uma massa de combustível líquido ou sólido ou por volume de gás. $\mathrm{Na}$ prática, os autores afirmam que o calor de 
combustão é determinado por medida direta em instrumentos denominados calorímetros. Certa quantidade de combustível é queimada num vaso fechado e imerso em água no interior do calorímetro. O calor liberado durante a combustão é transferido para uma massa de água conhecida, por intermédio das paredes do vaso. E, como a capacidade calorífica do material do vaso e a diferença de temperatura da água antes e depois da combustão, que também são conhecidas - o calor de combustão do combustível pode ser então, calculado, e isso é feito via software por meio do sensor sonda lambda. E, devido aos combustíveis oxigenados, como o etanol, éteres ou ésteres de ácidos graxos apresentarem um valor calorífico mais baixo do que os hidrocarbonetos puros (como é o caso da gasolina), logo seu uso permite menor desempenho que o motor com uso do combustível a gasolina. Ou seja, o oxigênio ligado aos mesmos não contribui para o processo de combustão, cabendo então compreender o porquê o combustível etanol oferece uma potencia inferior aos outros tipos de combustíveis como o da gasolina, e em função disso é que houve a equiparação de preços a $70 \%$ ao preço da gasolina. Verifica-se, portanto, que o etanol e a gasolina têm características diferentes. Aspectos como poder antidetonante, poder calorífico e ponto de ebulição, entre outros, que por sua vez exigem dos motores características distintas para trabalhar com um ou outro combustível. E, de acordo com Machado (2008, p.19-21), o poder calorífico da gasolina C é de $9.600 \mathrm{kcal} / \mathrm{kg}$, enquanto a do etanol é de $6.100 \mathrm{kcal} / \mathrm{kg}$. Caracterizando-se, portanto, como fator físico na delimitação dos $70 \%$ de relação comparativa de preços entre gasolina C e etanol hidratado.

Segundo Nigro (2009), as diferenças no poder calorífico oferecido pelo tipo de combustível ou mistura entre etanol e gasolina, exigem relações estequiométricas (proporção correta entre ar e combustível) distintas para a realização do mesmo trabalho. E, somente com os sinais da sonda lambda é possível monitorar as características da combustão que por sua vez, comanda novos parâmetros para o tempo de injeção e de ignição, fazendo com que a mistura e a combustão mudem suas características até atingir níveis considerados ideais para o combustível em uso. Com isso, o motor não sofre nenhuma alteração e seu funcionamento e adaptação se dá com base nas informações da sonda lambda captados na combustão. Esse foi o ponto compreendido por algumas empresas sistemistas, dentre elas a Magneti Marelli, localizada na cidade de Hortolândia-SP, no desenvolvimento do veículo flex, que por meio de seu arrojo tecnológico a partir da injeção eletrônica e via sensor de oxigênio viabilizou economicamente e obteve o aceite pelas montadoras. 
Entretanto, por mais que haja corrida tecnológica na indústria automotiva o preço do combustível é o mais importante, pois é o preço pago pelo consumidor final que influência em qual tipo de combustível, etanol ou gasolina, irá abastecer. Por outro lado, essa tecnologia desenvolvida pelo setor automotivo não mais determina a escolha na compra do veículo tendo como parâmetro o tipo de combustível. Assim, o uso do etanol nos motores Otto (veículos leves), e o alcance da eficiência produtiva, permitiu respectivamente que a tecnologia flex e os desenvolvimentos empregados na produção de etanol de $1^{\text {a }}$ geração, representassem os principais marcos na propulsão do mercado de combustíveis, onde de um lado tem-se a demanda e de outro a oferta, uma vez que, a projeção da demanda por etanol é promissora decorrente da viabilidade e aceitação do flex.

Sob outro aspecto, é pertinente enfatizar que em relação ao processamento da cana algumas perspectivas já estão sendo trazidas para o setor. Mais uma vez por meio das inovações as quais vêm vencendo fronteiras tecnológicas e permitindo várias finalidades, a partir da matéria-prima cana-de-açúcar, em seu uso que não somente ao fabrico do açúcar e etanol como também, recentemente, eteno e farneceno.

De acordo com Marques (2010, p. 83-88), já é uma realidade no mercado nacional a obtenção do eteno a partir do etanol, e o processo ocorre através da desidratação do etanol na presença de catalisadores, cujos contaminantes gerados no processo devem ser removidos através de sistemas apropriados de purificação, sendo este o grande salto tecnológico atingido pela empresa Braskem. O eteno, segundo o autor, possui pureza adequada para qualquer processo de polimerização e permite a obtenção de qualquer tipo de polietileno. A partir dessa constatação, o Brasil pode tornar-se referência mundial acerca desse otimismo promovido pela produção de eteno a partir do etanol. A preocupação, no entanto, fica por conta da garantia de fornecimento de açúcar e etanol carburante tanto para o mercado interno quanto para os mercados externos. Muito tem se falado sobre a construção de novas unidades, no aumento das lavouras de cana, para os usos alternativos da cana-de-açúcar (produção de eteno e farneceno), na capacidade de armazenagem e redistribuição das bases distribuidoras e na própria expansão da logística. Estes, por sua vez, implicam na necessidade de grandes investimentos a fim de evitar problemas de abastecimento.

A perspectiva é: será possível obter este crescimento sustentado no futuro próximo? Quais os 
principais desafios a serem enfrentados, no campo agronômico, industrial e logístico? Estes assuntos norteiam novas frentes de pesquisas futuras.

Com relação à competitividade da cana-de-açúcar ao fabrico do eteno, a partir do etanol, Marques (2010, p. 128), relata que essa matéria-prima verde só será mais competitiva que a nafta (derivado do petróleo) quando o preço do barril do petróleo superar US\$ 55, aí em contrapartida o etanol seguramente se tornaria mais vantajoso como substituto da principal matéria-prima da cadeia petroquímica brasileira. Diante dessa expectativa, os investimentos na oferta de etanol vêm sendo promovidos para o setor sucroenergético, e estes sendo feitos em diversas regiões do país como Estados de São Paulo, Minas Gerais e Goiás.

Segundo Castiglioni ${ }^{1}$ (2004 apud MACEDO; NOGUEIRA, 2005), é bastante provável que a expansão ocorra no Centro-Oeste do país, ocupando áreas do Cerrado hoje ocupadas com pecuária e cultivo da soja. Entretanto, Ângelo Bressan (Diretor do Departamento de Açúcar e de Álcool do Ministério da Agricultura, Pecuária e Abastecimento), atesta em fórum promovido pela Revista IdeaNews em maio de 2005, que a construção de novas unidades geralmente é um segredo comercial e privado. Eles mantêm essa informação por algum tempo para estudar preço de terras, melhor localização, cotação de equipamentos e outros assuntos que envolvam esse tipo de empreendimento, sob esse aspecto fica difícil detectar qual será de fato a nova fronteira para o aumento da produção de etanol.

Por outro lado, nas observações de Vian (2002, p. 69), observou-se que a estratégia de especialização e capacitação produtiva traz boas perspectivas futuras de sobrevivência e de expansão do setor sucroenergético no longo prazo, pois é ela que carrega a possibilidade de se alcançar maior eficiência produtiva. Tal estratégia demanda significativo aporte de recursos e está diretamente relacionada aos processos de concentração e centralização de capitais, e indica a possibilidade de uma efetiva reestruturação do ramo, por passar a ser um processador de biomassa e produtor de vários bens derivados dela.

Com respeito ao uso alternativo do etanol para produção de farneceno. O alcance dessa tecnologia é semelhante com o da produção de etanol combustível, que utiliza leveduras (fungo microscópico) para fermentar os açúcares presentes na cana e secretar etanol. Sua

\footnotetext{
${ }^{1}$ Comunicação ao Centro de Gestão e Estudos Estratégicos - CGEE, por Vânia Beatriz R. Castiglioni, Embrapa, 2004.
} 
tecnologia é tida como segredo industrial e reside no DNA da levedura, que foi geneticamente modificada para secretar diesel no lugar de etanol. Desse modo, o mesmo caldo de cana que serve como matéria-prima para a produção de açúcar, etanol e eteno será também dividido com a produção de diesel. Essa nova tecnologia está sendo desenvolvida pela empresa Amyris, da Califórnia, e que também possui uma unidade de pesquisa na cidade de Piracicaba-SP. De acordo com a empresa, projeta-se, em sociedade com a Votorantim Novos Negócios e a Companhia Energética Santa Elisa, de Sertãozinho, produzir 1 bilhão de litros, em 2012. Alguns testes já estão sendo ensaiados por algumas montadoras, como a Fiat, em seus caminhões, outros já estão sendo promovidos pela prefeitura de São Paulo em seus ônibus de circulação. A notícia da Fiat foi veiculada pelo jornal inglês Economic Times, ao qual está sendo investido cerca de 10 milhões de euros. A tecnologia permite que não só o motor possa ser movido a diesel proveniente da cana, como também possuir um sistema de alimentação, que mistura o etanol com óleo diesel na hora da entrada no cilindro. Os dois combustíveis seriam armazenados em tanques separados, sendo que o óleo diesel seria usado em porções mínimas, apenas para dar início à combustão. A partir daí, o etanol seria injetado.

Dada a flexibilidade de produção da usina, que pode produzir açúcar, etanol hidratado e etanol anidro dentro de certos limites. Fica difícil estimar qual a produção de etanol assegurada, pois o que determina a produção nos planejamentos das usinas ou destilarias é a demanda e sua respectiva capacidade relacionada à margem de lucratividade e liquidez frente aos usos alternativos possíveis. Ao considerar as estimativas da UNICA de produção etanol para a safra 2020/2021 em torno de 64 bilhões de litros; e, na expectativa da demanda atingir patamares ao redor de 55 bilhões de litros, sem considerar as variações nas cotações dos barris de petróleo e do mercado de commodities do açúcar: fica evidente que a oferta de etanol é quase que limitada pela demanda, sendo a demanda ainda exclusa da possibilidade do etanol servir outros usos, que por sua vez, implicaria numa relação muito próxima entre oferta e demanda o que resultaria, portanto, na elevação dos preços. Ou seja, cabe ressaltar que qualquer avaliação da capacidade instalada para produção de etanol tem de levar em conta o açúcar a ser produzido, usos alternativos, os preços dos produtos no mercado, e em particular no mercado internacional, visto que são fortes influenciadores da produção a ser obtida.

Expandir unidades produtoras representa uma alternativa, uma vez que, se aumentar a produção de etanol nas usinas já instaladas, o gargalo será o setor de recepção, preparo e 
extração. Estes demandarão investimentos para aumento da capacidade de processamento de cana (moagem), bem como em setores auxiliares (tratamento do caldo, geração de vapor, geração de eletricidade etc.), sem considerar o fato da maioria das unidades produtoras possuírem planta industrial da época do Proálcool. Ou seja, para produção de etanol é mais oportuno expandir unidades produtoras que operar acima da capacidade produtiva das quais

muitas são contemporâneas à fase do Proálcool. É oportuno considerar que tal expansão implica na necessidade de infraestrutura por rodovias e tanques de armazenagem de etanol e a avaliação dos aspectos relacionados à segurança alimentar quanto ao uso da terra.

Fica evidente que, diante dessas constatações, e ao retratar a expectativa da expansão da produção de etanol no país, pergunta-se, inicialmente, qual é a capacidade instalada? Não há uma resposta direta para esta pergunta. $\mathrm{O}$ que se sabe é que ela não depende mais somente da produção desejada de açúcar e etanol, como também de eteno e tão logo o farneceno. As usinas e destilarias atuais são flexíveis para a produção de açúcar e etanol, e esta produção tem origem na mesma cana moída, no mesmo caldo, e estes são matérias-primas para os usos alternativos e decidido pelo produtor.

Portanto, a tecnologia tem proporcionado usos alternativos a partir da cana-de-açúcar, que somado à crescente demanda por combustível etanol e açúcar, revela ao setor a grandeza necessária em aumento de produtividade. Exigindo, empregos tecnológicos, por meio de melhorias genéticas nos cultivares e na dosagem de polímeros, e inclusive com a expansão de plantio.

\subsection{Flex Fuel: fusão dos mercados da gasolina C e etanol hidratado}

O veículo flex fuel está vinculado ao desenvolvimento do motor a etanol ocorrido na década de 80 , em que o aumento na demanda do consumo de etanol no Brasil, fomentado pelo programa governamental Proálcool, contribuiu para o desenvolvimento comercial do motor a etanol. Por conseguinte, a tecnologia favorece as decisões do consumidor final na hora do abastecimento os aspectos ambientais e contribui também para o comportamento dos preços do etanol no mercado interno, por transferir a decisão do abastecimento ao consumidor. Por vezes isso também se deve à constituição em paralelo de regulamentos realizados por meio de órgãos institucionais como o Proconve, e outros que pavimentaram o sucesso na realização da 
tecnologia flex e que impulsionou o mercado do etanol.

Os principais objetivos deste programa visam diminuir a contaminação do ar pela fixação de normas de emissão, promovendo desenvolvimento tecnológico pelas montadoras e criando mecanismos para garantir o cumprimento de normas nas emissões da combustão de gases. A introdução de catalisadores e injeção eletrônica contribuiu para atender os objetivos fixados pelo governo. Percebe-se que essas normatizações foram relevantes para motivar a inovação tecnológica alcançada com oflex, que se iniciou com o sistema de injeção eletrônica.

Para Nascimento et al (2009b, p. 03), dentre as décadas de 1970 a 1980, o sistema de injeção eletrônica de combustível, com suas unidades de comando eletrônico (ECU - Electronic Control Unit) e seus softwares específicos, substituiu o antigo carburador mecânico e elétrico. O setor automobilístico apresentou um sistema de injeção eletrônica, que, conjuntamente com o know-how do carro a etanol, possibilitou na década de 2000 o lançamento do veículo flex fuel. E o Proconve, em outubro de 1993, por meio de suas metas obrigatórias de redução de emissão de poluentes atmosféricos pelos veículos, já contava com um sistema de injeção eletrônica que substituía totalmente os antigos carburadores de tecnologia mecânica e elétrica e que contribuía para a diminuição da poluição do meio ambiente.

Segundo Pefley (1980, p. 54), no ano de 1980, já havia discussões iniciadas sobre o sistema de injeção eletrônica capaz de operar com uma mistura de etanol e gasolina por meio de um sensor capacitivo nos EUA. Entretanto, somente em 1991 é que eles foram conhecidos pelo mercado e chamados de veículos flex fuel. Cabe destacar que a palavra flex fuel é de procedência americana. Não se trata de um termo próprio por conta dessa nova tecnologia, não tem ligação com a técnica em si, mas é como ela se identifica no mercado consumidor brasileiro, sendo as montadoras responsáveis pelo seu uso e pela própria propagação da tecnologia. Assim sendo, flex ou bicombustível é o nome dado à tecnologia que permite aos veículos utilizar gasolina, etanol ou qualquer proporção da mistura de ambos como combustíveis.

De acordo com Nascimento et al (2009a, p. 112), o princípio funcional da injeção flex fuel se dá pelo monitoramento eletrônico constante de diversas variáveis do motor (ar, combustível, temperatura, faísca entre vários outros). É processada por um computador central e por um 
programa de software específico que processa e comanda a operação do motor para cada condição de uso. Estabelece-se, portanto, por bicombustível a tecnologia flex fuel ao qual permite o uso por dois tipos de combustíveis, e por biocombustível trata-se de combustível proveniente da biomassa, como: etanol e biodiesel.

O propósito do veículo flex fuel (FFV) não é somente promover uma fonte de energia alternativa de combustível, mas também demonstrar sua eficácia comparativa a outros combustíveis nas emissões de gases poluentes. Sob esse aspecto, é oportuno ressaltar que a tecnologia flex é de origem norte-americana. Surgiu com a finalidade de reduzir as importações do petróleo e seu uso era para atender o E85, uma mistura de combustível de $85 \%$ de etanol anidro e $15 \%$ de gasolina, tendo como base a tecnologia que estava disponível para veículos motorizados a metanol e à gasolina nos Estados Unidos, e, posteriormente, movidos a etanol na década de 1980. O bicombustível híbrido, motores movidos à gasolina e etanol (flex fuel, como são chamados no Brasil), foi, portanto, trazido para o Brasil no ano de 1990 não em escala de produção, mas em níveis de desenvolvimento e testes (GATTI JUNIOR, 2010, p. 96).

Para Nigro e Szwarc ${ }^{2}$ (2009 apud GATTI JUNIOR, 2010, p. 99), o grande desafio do motor flex foi quanto à sua injeção bicombustível, em comparação à injeção de gasolina (E25) ou etanol puro (E100), cuja rápida detecção e ajuste do motor devem ser reconhecidos a cada mudança de mistura gasolina-etanol. No início, a tecnologia de sonda lambda, produzida por empresas sistemistas, não foi suficiente para convencer o interesse das montadoras em produzir em larga escala carros flex fuel. O cenário deixado pelo etanol no mercado de combustíveis, após a fase de estagnação do Proálcool, como: desestímulo fiscal, liberalização das importações, elevações nos preços da commodity açúcar, a credibilidade do consumidor ao carro à gasolina e à própria tecnologia do motor movido a etanol; deixava um legado de desconfiança às montadoras.

No entanto, o desenvolvimento da tecnologia flex contava no início com um cenário do mercado de combustíveis favorável, ao considerar a corrida de consumidores finais na conversão do motor à gasolina pelo movido a etanol, pressões ambientais, incentivos fiscais,

\footnotetext{
${ }^{2}$ NIGRO, F., SZWARC, A. Etanol como combustível veicular: perspectivas tecnológicas e propostas de políticas públicas”. UNICA- União da Indústria de Cana-deAçúcar, São Paulo, 2009.
} 
estabilização da moeda, a tecnologia sonda lambda, contando, inclusive, com a Companhia de Tecnologia e Saneamento Ambiental (Cetesb), que liderou a elaboração de um regulamento com a participação de montadoras e de fornecedores do sistema. Ou seja, independentemente da contextualização do mercado do combustível etanol promovida pela fase de estagnação do Proálcool, as empresas sistemistas apostavam no desenvolvimento tecnológico dentro de um cenário que se desenhava no mercado interno.

Sobral et al (2005, p. 74) relatam a trajetória da tecnologia flex fuel apresentando a empresa Magneti Marelli-MM, sob seu papel vanguardista em ser a primeira sistemista a equipar um veículo comercial usando um sistema de injeção com detecção de teor de etanol por meio do sensor de oxigênio (sensor lambda) e software, dispensando o uso do sensor capacitivo, o que por sua vez resultou no desenvolvimento do flex, ou seja, transformou a tecnologia, que em si era física, em um sistema lógico baseado em software. Como o carro já possuía o sistema para o processamento dos softwares por causa da injeção eletrônica, essa tecnologia praticamente saiu de graça para as montadoras. Assim, a MM destacou-se como a pioneira no desenvolvimento de um sensor de oxigênio (sonda lambda) para identificar, após a queima, a nova composição de combustível que alimenta o veículo. Isso decorria de experimentos acumulados desde 1999.

Ademais, a aprendizagem da experiência do etanol, as questões ambientais levantadas na Conferência das Nações Unidas para o Meio Ambiente e o Desenvolvimento (ECO-1992), realizada no Rio de Janeiro, a estabilização do preço do etanol (50\% do valor do preço da gasolina) e as novas metas de emissões determinadas pelo governo apoiaram a continuação da pesquisa sobre a solução flex fuel (GATTI JUNIOR, 2010, p. 98).

Outro fator que convergia à viabilidade para as montadoras decorria da observação do mercado de combustíveis em 2001. Nesse ano, uma série de conversões de motores à gasolina para o etanol já estavam ocorrendo em vista da baixa dos preços no mercado do etanol (pelo estoque que havia sido formado na fase de estagnação do Proálcool). A tecnologia bicombustível (flex), na ótica dos autores Nascimento et al (2010, p. 04), decorreu de programas existentes que visavam enfrentar as crises de petróleo no mercado mundial, e, conforme visto, o Proálcool foi um deles, o qual teve por objetivo conduzir a produção de etanol anidro (etanol 99,5\%), adicioná-lo à gasolina em uma taxa que não exigiria 
modificações no motor (uma percentagem entre $10 \%$ e $15 \%$ ou E10 e E15, respectivamente), podendo chegar a até $25 \%$ com menores adaptações no projeto do motor, e servindo este como, atualmente, estoque balanceador na oferta de etanol para o mercado interno quando há grandes volatilidades de preços.

De acordo com Nascimento et al (2009a, p. 113), na década de 2000, a tecnologia flex fuel é, portanto, aceita pelas montadoras brasileiras, que tentam se beneficiar dos atuais canais de distribuição de etanol anteriormente já existente nos postos de combustíveis, uma vez que para cada posto de combustível havia uma bomba de abastecimento de gasolina e outra de etanol. Adicionalmente, os autores afirmam que, no início, a infraestrutura da distribuição do etanol foi criada e mantida; e por outro lado, manteve-se a frota de veículos movidos a etanol devido ao desestímulo das montadoras em produzi-los, uma vez que os consumidores de veículos demandavam carros movidos à gasolina, pois estes eram passíveis de encontrar abastecimento nos postos. Tudo isso, portanto, perfazia o cenário no qual as empresas sistemistas atuavam durante o desenvolvimento da tecnologia flex fuel.

Para Goldemberg et al (2008, p. 33), a tecnologia de veículos flex fuel foi lançada efetivamente em 2003, e alcançou em menos de cinco anos uma participação de mais de 90\% de veículos leves produzidos.

Esta nova tecnologia, segundo Nascimento et al (2009a, p. 113), mudou o processo de escolha entre o mercado de veículo movido somente a etanol ou à gasolina, ou então o híbrido, que contempla os dois tipos de combustíveis: conhecido por bicombustível - flex. A decisão pelo flex transpõe a que combustível abastecer. Uma decisão que vigora ao consumidor final a autonomia de abastecimento sobre o preço praticado entre o combustível etanol e a gasolina. Vale destacar que, no Brasil, a mistura de etanol à gasolina data de 1919 (PEREIRA, 1986). Outros países, como a Índia, Mauritânia, Austrália e vários países da Europa e da América Latina, iniciaram o seu uso como aditivo ao combustível na década de 1930.

Retomando, tal tecnologia promoveu a difusão dos veículos denominados flex fuel, permitindo que regras de mercado, em função da relação de preços dos produtos substitutos, sejam mais comumente observadas. Se por qualquer razão o preço do etanol subir em relação à gasolina, o consumidor imediatamente poderá reagir, dando ao mercado o sinal adequado, 
levando a uma oferta maior de etanol hidratado, o que por sua vez tende a reduzir, consequentemente, seu preço.

Segundo Nascimento et al (2010, p. 04), a rápida difusão desta tecnologia no Brasil foi representada: pela rede de distribuição estabelecida de etanol, por pressões governamentais por meio de suas instituições que impunham normas e regulamentos para a utilização de combustíveis menos poluentes obtidas a partir de fontes renováveis, pela abertura do mercado brasileiro e, também, pelo próprio desenvolvimento da tecnologia flex fuel, que obteve aceite por parte do consumidor final. Outros aspectos que favoreceram foram os incentivos proporcionados pelo governo em aspectos tributários e impositivos para que todos os postos de combustíveis brasileiros tivessem dois tipos de bombas: etanol hidratado e outros com a mistura de gasolina e etanol anidro (a proporção da mistura pode variar de ano para ano de acordo com condições de mercado). Esse conjunto de fatores consolidou, portanto, o surgimento da tecnologia flex fuel, demarcando uma nova configuração no mercado dos combustíveis etanol hidratado e gasolina $\mathrm{C}$.

Sob o aspecto regulatório em incentivos, Nascimento et al (2009b, p. 05) atestam que, em dezembro de 2002, o Governo Federal promulgou, pela Lei $\mathrm{n}^{\mathrm{o}}$ 10.636, tratando de um regulamento de incentivo a projetos voltados à produção de biocombustíveis, com foco na redução dos poluentes, o que contemplaria a produção de motores equipados com a tecnologia bicombustível, enquadrando definitivamente os veículos bicombustíveis na mesma categoria que o etanol para fins tributários e fiscais. O sucesso dessa difusão tecnológica do flex pode ser constatado com os dados da Anfavea (2010), os quais revelam que, do total de 2.711.267 veículos comercializados no ano de 2009 no país, 2.541 .153 eram flex, ou seja, 94\% da frota produzida. Para Nigro e Szwarc $^{3}$ (2009 apud GATTI JUNIOR, 2010, p. 92), várias montadoras passaram a investir nessa tecnologia e impulsionar o mercado do combustível etanol hidratado, retomando sua credibilidade, viabilidade e demanda.

Compreende-se que os veículos flex fuel teve em sua primeira geração um desenvolvimento voltado ao atendimento dos limites de emissão. Uma vez que a tecnologia se consolidou no mercado e tendo o aceite pela indústria automobilística, surge a preocupação com a prática

\footnotetext{
${ }^{1}$ NIGRO, F., SZWARC, A. Etanol como combustível veicular: perspectivas tecnológicas e propostas de políticas públicas”. UNICA- União da Indústria de Cana-de-Açúcar, São Paulo, 2009.
} 
dos preços do etanol, uma realidade que vem sendo assistida, uma vez que a demanda pelo combustível etanol hidratado e açúcar se elevou devido, respectivamente, à inserção do flex e pela elevação das exportações do açúcar.

Somado a isso, vários outros fatores são aguardados diante da prospecção dos usos alternativos da cana-de-açúcar, na esperança de que também possam interferir para o desalinhamento dos preços nas mais variadas regiões do país. Por ora, a diferença nos preços é balanceada ao seu equilíbrio de mercado pelo consumidor final, o qual apresenta autonomia na hora do abastecimento, pois pode escolher qual tipo de combustível comprar.

\subsection{Mercado internacional do combustível etanol}

Como já observado anteriormente, há dois tipos de etanol carburante, o anidro e o hidratado; ambos são combustíveis usados em veículos de passeio e comerciais leves, que diferem quanto ao seu uso. Sua viabilidade no mercado global se dá devido ao aumento do teor de oxigenados na gasolina, e, por conseguinte, o etanol permite a redução da emissão de $\mathrm{CO}_{2}$ sendo um substituto do chumbo tetraetílico (MTBE: methyl tertiary butyl ether), altamente poluente, tomado, portanto, como um combustível alternativo e ambientalmente limpo.

Atualmente, grande parte do etanol combustível destina-se ao consumo interno, uma vez que o comércio internacional desse produto ainda é muito incipiente. Segundo dados da ANP (2010), o país no ano de 2009 exportou 3,3 bilhões de litros, de um volume em torno de 5 bilhões de litros comercializados mundialmente, cerca de $20 \%$ foram destinados para combustível, sendo os $80 \%$ restantes para uso industrial e para bebidas.

Baseando-se nos estudos de Farina et al (1997), que observam que o comportamento oportunista é fruto do autointeresse e das condições criadas por ambientes cuja informação é assimétrica, o atual mercado do combustível etanol enquadra perfeitamente nisso, pois decorria de um ambiente incerto, cuja tecnologia e as estruturas herdadas do Proálcool constituíram-se como fortes aliados à atual consolidação do mercado, e pode unir-se aos interesses ambientais. Adicionalmente, têm-se as dimensões internacionais que formam um cenário promissor no setor como um todo, que, de certa forma, pode confrontar com a oferta do combustível etanol hidratado no mercado interno. 
Conforme dados apresentados pelo Plano Nacional de Agroenergia (MAPA, 2005, p. 66), os Estados Unidos devem produzir 30 bilhões de litros de etanol em 2020. Contudo, se houver déficit no mercado americano de etanol, ele poderá ser coberto pelas importações dos países do Caribe, que importam o etanol brasileiro para reprocessamento, representando um cenário promissor para os investimentos nas plantas produtivas brasileiras.

Nos estudos apontados pelo MAPA (2005, p. 68), há também o mercado japonês, que é o segundo maior consumidor de gasolina do mundo, com cerca de 60 bilhões de litros de demanda por ano e 40 bilhões de litros de diesel importados do Oriente Médio (99\% do petróleo é importado). O país é, atualmente, um dos mais preocupados com questões ambientais (Protocolo de Kyoto), principalmente depois da descoberta da presença nas águas japonesas de MTBE (Éter Metil-Terciário Butílico, uma molécula criada a partir do metanol que eleva a octanagem e tem impactos ambientais). Foi constatado também que o Japão em sua legislação atual já prevê $3 \%$ de mistura de etanol voluntária nos combustíveis. Se essa porcentagem se tornar compulsória, gerar-se-á uma demanda garantida de 1,8 bilhões de litros ao ano e se o percentual de $10 \%$ for adotado, a demanda se aproximará de 6 bilhões de litros.

Sob esse aspecto, o objetivo do governo e dos empresários nacionais é conquistar o mercado japonês de etanol. Embora haja essa expectativa, Nastari (2004, p. 59) acrescenta a existência de subsídios concedidos aos produtores americanos e europeus de etanol que comprometem a competitividade do combustível brasileiro, além das barreiras à importação por parte desses países. Com isso, a saída para o Brasil é negociar o acesso a esses mercados. Para o autor, essa ação já foi iniciada em 2004, com a inclusão do etanol na agenda das negociações entre o Mercosul e a União Europeia, envolvendo uma cota de importação de 1,2 bilhão de litros do combustível por ano. Assim, o interesse estratégico do Brasil na disseminação do uso do etanol como combustível passa pela expansão dos mercados compradores tradicionais (tanto interno quanto externo), pela abertura de novos mercados e pela transferência remunerada de sua tecnologia de produção, exportando suas tecnologias sem nenhum impeditivo comercial, para que a demanda no mercado externo seja sustentável, fluindo também em expectativas que considerem as possibilidades produtivas que a cana e o etanol oferecem, como: açúcar, farneceno e o eteno.

Dentre essas expectativas da demanda internacional, constroem-se as preocupações quanto à 
ineficiência no escoamento ou transporte do etanol, constituindo-se no gargalo tanto para atender a expansão do mercado interno quanto as exportações. E, segundo estudos do MAPA (2005, p. 75), isso se dá na medida em que se reduz a competitividade do produto brasileiro lá fora, já que $60 \%$ das cargas que vão até o porto são transportadas via rodovia (pois as dutovias ainda não estão plenamente construídas das bases produtoras até a refinaria), encarecendo o combustível. Esse aspecto logístico norteia a diferença do preço do etanol, pois, embora o Brasil seja extremamente competitivo na produção do etanol, há um importante gargalo logístico na cadeia desse produto a ser resolvido. Isso pode trazer dificuldades para os produtores nacionais em atender o crescimento da demanda externa, e tal risco para o produtor permite que em sua mesa de negociações o açúcar exerça certa prevalência, e, por conseguinte, comprimindo os preços no mercado interno.

Por outro lado, esses fatores levam ao consumidor final de etanol hidratado no mercado doméstico a necessidade de uma confiança no pleno abastecimento. O consumidor almeja acesso a preços competitivos para o produto, para que não ocorra outra crise como a que se assistiu no final dos anos 1980, quando o Proálcool caiu totalmente em descrédito diante da queda nos preços do petróleo e aumento na produção de açúcar, em detrimento da produção de etanol. Ou seja, se ocorrer, de fato, uma expansão da demanda no mercado mundial de etanol durante a fase de expansão da capacidade produtiva do setor, deve haver uma pressão na demanda e nos preços do combustível que só será sanada pela expansão produtiva, pelo mercado regulatório, pela estrutura logística e de abastecimento no mercado interno.

Atualmente, o mercado internacional para o etanol é baixo, e o Brasil tem grande participação na exportação. Pezzo e Amaral (2007, p. 22-26) alegam que essa pequena quantidade está ameaçada de não conseguir atingir seus mercados de destino, pois a elevação da demanda interna e as tarifas impostas pelos importadores são tão altas que só se torna viável a venda quando os preços do etanol atingem patamares muito elevados, como aconteceu no mercado norte-americano em 2006. Nesse ano, o etanol produzido a partir de cana-de-açúcar conseguiu ser competitivo no mercado dos Estados Unidos, onde se concentram altos volumes de subsídios e taxas de importação.

Nos Estados Unidos, diferentemente do Brasil, o etanol é produzido a partir de milho, que, segundo Pezzo e Amaral (2007, p. 22-26), tem balanço energético baixo, quando comparado 
ao de cana-de-açúcar, porque a conversão da planta em energia é baixa, além de a produção ser dependente de grandes quantidades de insumos agrícolas, tais como fertilizantes e defensivos. Vale destacar os estudos feitos pela Organização para a Cooperação e o Desenvolvimento Econômico (OECD), os quais descrevem que, em 2004, para cada unidade de energia fóssil investida, é produzida entre 1,25 e 1,66 unidade de energia renovável a partir do milho, enquanto no caso do etanol de cana-de-açúcar resultam entre 8,3 e 10,2 unidades. Esse dado revela ao mercado internacional o potencial produtivo que a cana-de-açúcar oferece para a produção de etanol. No mercado americano de etanol, há perspectiva, segundo o Renewable Fuels Standard Program, de um consumo de 36 bilhões de galões de etanol até 2022 - o que representará aproximadamente 140 bilhões de litros. Segundo a Agência de Proteção Ambiental dos Estados Unidos (EPA, da sigla em inglês), já há um dispositivo regulatório que permita a elevação da mistura de etanol na gasolina de $10 \%$ para $15 \%$. Tal medida vale para veículos e caminhões leves, de modelos fabricados a partir de 2007 até os modelos novos, e constitui-se como um dos fatores propulsores da perspectiva de produção de etanol até 2022. Nesse sentido, os EUA apresenta uma projeção otimista na produção de etanol, que não necessariamente virá suprir seu mercado local, uma vez que somente a demanda em função do E-15 num mercado atual de 550 bilhões de litros de gasolina já comprometeria o fornecimento, cabendo a necessidade de importar etanol de outros países.

De acordo com Silva (2010, p. 96), para que seja economicamente viável atuar nesse mercado, será necessário superar as barreiras tarifárias. Nesse mercado internacional, de exportação de etanol para os Estados Unidos, vigoram duas tarifas: a primeira é a tarifa primária que está prevista em acordo com a Organização Mundial do Comércio, de 2,5\%; e, a segunda tarifa, ou tarifa secundária, corresponde a 54 cents por galão, ou 19 cents por litro, para o etanol importado. E, de acordo com o autor, essa tarifa de 54 cents por galão perdurou até o ano de 2000; atualmente, ela é aplicada em 45 cents e vista como uma medida compensatória do governo americano aos distribuidores de gasolina que antes tinham uma isenção de 54 cents por galão. Sob esse aspecto tarifário/tributário nas importações, explica-se o incentivo na produção local, atendendo também aos interesses ambientais, porém tal ação implica na competitividade do etanol brasileiro.

Outro fator apontado como desafio para os EUA, segundo Silva (2010), é quanto à redução de $\mathrm{CO}_{2}$, uma vez que o mercado americano está dividido de acordo com a capacidade dos 
diferentes tipos de matéria-prima para produzir etanol para fazê-lo. Essa divisão está entre a produção do etanol no modo convencional, o avançado e o celulósico. O etanol convencional é capaz de reduzir o $\mathrm{CO}_{2}$ em até $20 \%$ comparado com a gasolina. O etanol de milho enquadra-se nessa categoria e estima-se um limite máximo de consumo de $40 \%$ em 2022 , sendo que, nos demais $60 \%$, será necessário adotar o etanol avançado, que chega a reduzir $50 \%$ a emissão de $\mathrm{CO}_{2}$ comparado com a gasolina.

Após os EUA, o segundo maior mercado mundial de etanol é o europeu, que, segundo Silva (2010, p. 96), também tem projeções de ser atrativo no futuro, ao considerar o prazo de até 2020, determinado pelo Conselho da União Europeia, quando todos os 27 países do bloco devem utilizar $10 \%$ de combustíveis renováveis em seus combustíveis. Sob esse aspecto, corridas tecnológicas estão sendo exploradas, uma vez que o etanol se apresenta apenas como alternativa, pois outras fontes estarão concorrendo, como a eletricidade.

De acordo com a UNICA (2010), o potencial do mercado europeu em importações de etanol está em torno de 14 ou 15 bilhões de litros até 2020. Vale destacar que a União Europeia não tem um programa como o etanol de milho ou de cana-de-açúcar, visto que lá a escala produtiva é ainda menor e provém da beterraba e trigo. Esse mercado também conta com barreira tarifária, 19 cents de euro por litro, maior que a americana.

O terceiro maior mercado mundial de etanol combustível é o asiático. Para a UNICA (2010), neste concentra-se boas perspectivas de exportações, e já há algumas localidades que regulamentaram a mistura entre 5 e $10 \%$ de etanol, apesar desse continente contar com condições geográficas e tecnológicas para produção de etanol.

A observação que se faz é que políticas públicas no mercado externo são direcionadas ao meio ambiente e regulamentam normas de misturas obrigatórias. Decorrente disso, surge um mercado internacional promissor de longo prazo, cabendo ao mercado local planejar ações que gerem liquidez, como mercados futuros e contratos de longo prazo, sustentados por uma referência de preços e um conjunto maior de informações de oferta e demanda sem que balizem significativamente os preços no mercado interno. 


\subsection{Regulamentos ambientais no mercado do etanol}

Neste tópico, a ênfase é quanto à preservação do meio ambiente por meio de regulamentos, no sentido de promover a produção de etanol de maneira sustentável, tendo como base o processo de conscientização e aprimoramento da importância do bem-estar ambiental para a sobrevivência e verdadeiro desenvolvimento da humanidade.

Por desenvolvimento sustentável, segundo Valdés (2000, p. 19-23), entende-se aquele que satisfaz as necessidades presentes sem comprometer a possibilidade de que as futuras gerações satisfaçam as suas próprias necessidades, de modo que a manutenção dos estoques dos recursos naturais sejam indispensáveis para a continuidade da atividade econômica. Ou seja, a preocupação com as emissões de gases a partir do uso de combustíveis e na produção de etanol, revelada com aspectos regulatórios e tecnológicos, representa uma atenção direcionada ao desenvolvimento sustentável, pois está diretamente relacionada com impactos ambientais, como, por exemplo, os gases de efeito estufa. Ressalta-se que o etanol de cana-deaçúcar é uma das melhores opções nas emissões de gases que impactam no efeito estufa comparados a outros decorrentes da queima de combustíveis fósseis. Além disso, a cogeração de energia a partir do bagaço de cana é uma alternativa às termelétricas e até às hidrelétricas mais complexas.

As emissões veiculares de poluentes regulamentados pelo uso de etanol são comparáveis e até inferiores às de gasolina e diesel. Contudo, não se podem ignorar as pressões causadas pela vigorosa expansão da cultura da cana-de-açúcar no país, ainda que isso esteja ocorrendo predominantemente sobre áreas de pastagem pouco aproveitadas, e as queimadas da cana em períodos de safra.

Segundo Goldemberg et al (2008, p. 34), um fato importante aos aspectos da sustentabilidade no plantio da cana-de-açúcar foi a aprovação da Lei Estadual no 11.241/2002, no Estado de São Paulo, que estabelece o uso de máquinas nas áreas mecanizáveis para o ano de 2021 e, a partir de 2031, nas áreas atualmente não mecanizáveis. O prazo maior pressupõe que a tecnologia do maquinário de corte será adaptada para o atendimento de áreas com maior declividade. A legislação também estabelece a instituição gradual da mecanização antes desses prazos; por exemplo, até 2016, 80\% das áreas de pouco declive devem estar mecanizadas e $10 \%$ das áreas atualmente não mecanizáveis devem ser mecanizadas. Além 
disso, os autores ainda sustentam que um acordo entre usineiros e ambientalistas originou o surgimento do Protocolo Agroambiental em 2007. Este antecipa para 2014 o fim da queima da palha da cana-de-açúcar nas lavouras mecanizáveis do Estado de São Paulo e, para 2017, nas áreas atualmente não mecanizáveis. Este protocolo, que tem caráter voluntário, apresentou adesão, em março de 2008, de $85 \%$ das usinas do Estado de São Paulo e também da Associação dos Fornecedores de Cana.

De acordo com Lanzotti (2000, p. 29), as queimadas de canaviais, conforme o publicado em 06 de agosto de 1997, por meio do Decreto Lei de $\mathrm{n}^{\circ} 42.056$, que destaca a prática de "despalha" de cana-de-açúcar pela queima, como método auxiliar da colheita, estão proibidas no Estado de São Paulo, admitidas apenas excepcionalmente em caráter transitório. É oportuno destacar, segundo o autor, que áreas de colheita mecanizável representam os canaviais instalados em terras com declividade menor que 12\%. A prática da "despalha" da cana pela sua queima poderá ser realizada em horário a ser determinado por Resolução Conjunta da Secretaria de Agricultura e Abastecimento, Secretaria de Meio Ambiente e Secretaria do Emprego e Relações do Trabalho do Estado de São Paulo.

Acrescentam-se a esse fato os estudos realizados por Berni e Bajay (1998, p. 30), sustentando que a queima da cana-de-açúcar não só é fator preocupante ao meio ambiente como também ao meio social. Cumpre destacar que, ainda no Decreto Lei de $n^{\circ} 42.056$, instituído no Estado de São Paulo, há a limitação das queimadas no raio de um quilometro dos núcleos urbanos, contando a partir do perímetro urbano efetivamente urbanizado, em áreas onde existem linhas de transmissão, linhas de distribuição de energia elétrica, aeroportos, rodovias e ferrovias. Evidencia-se, portanto, um ponto merecedor de destaque e que vem realçando esforços em investimento na cadeia produtiva do etanol, é quanto às queimadas que antecedem o corte da cana-de-açúcar. Ou seja, os esforços do governo visam regulamentar esse procedimento de forma mais racional, pois os efeitos da queimada devem ser prejudiciais não só para o meio ambiente, como para a saúde humana.

Nessa ótica, é oportuno frisar, segundo Ometto (2005, p. 24-25), que as queimadas nem sempre contribuem para o aquecimento global, se considerar que todo o gás carbônico emitido, tanto na queima quanto na combustão do etanol, é reabsorvido pela cana-de-açúcar em crescimento, reduzindo de forma significativa tal impacto. Já o Decreto Federal no 2.661, 
de 8/7/98 estabelece a eliminação gradativa da queimada da cana-de-açúcar no Brasil; ademais, existem também normas estaduais e municipais que vêm regulamentar e exigir investimentos e inovações na cadeia produtiva, tal como observado anteriormente na Lei Estadual $n^{\circ} 11.241 / 2002$ no Estado de São Paulo, que versa sobre a eliminação gradativa da queima da cana-de-açúcar (SÃO PAULO, 2002). Ou seja, essas são algumas medidas na ordem regulamentar de funcionamento do mercado para o setor sucroenergético, imprimindo para o setor necessidades de investimentos no presente (por exemplo: colhedora mecanizada e melhoria genética das mudas). Esse fato implica na composição de maiores custos aos produtores, que por sua vez impactam nos preços do combustível etanol.

De acordo com Amaral (2009, p. 14), os altos investimentos em colhedoras estão além da capacidade da grande maioria dos fornecedores de São Paulo, isso porque, para que a mecanização seja economicamente viável, o produtor deve dispor de uma escala mínima de 120 mil toneladas.

Segundo Paulillo e Mello (2005, p. 43), em cerca de $22 \%$ da cana fornecida às usinas, $80 \%$ são plantadas pelos fornecedores, sendo que estes possuem áreas de no máximo 22 hectares. Assim, acatar a legislação que proíbe a queima e poder beneficiar-se das inovações no plantio e cultivo torna-se oneroso ao pequeno produtor. Para os autores, os pequenos fornecedores de cana-de-açúcar se virão obrigados a se organizarem em consórcios e condomínios de mão de obra para que possam sobreviver na atividade e contar com maquinários e mão de obra dentro dos parâmetros legais. Desse modo, a colheita mecânica, quando vigorar seu uso obrigatório, irá onerar o pequeno produtor, podendo levar à concentração da produção agrícola ou até mesmo a uma reformulação de contratos e acordos preestabelecidos no fornecimento da cana.

Nota-se, portanto, que se abriu caminho para um novo processo de reordenamento das atividades do setor sucroenergético, sendo que o planejamento e a execução das atividades relativas à produção e à comercialização deixaram de ser orientados pelo governo e passaram a fazer parte da administração privada. Por conseguinte, os pequenos fornecedores também deverão enquadrar-se às normas impositivas no que compete aos aspectos ambientais como o caso da queima, o que implica em investimentos no curto prazo e em custos.

O Brasil possui 851,4 milhões de hectares de superfície total, sendo 354,8 milhões de hectares 
de área das propriedades rurais (com exclusão de áreas protegidas, corpos d'água e áreas inaptas para a agricultura e inclusão das reservas legais de formações nativas), que são dedicadas a pastagens naturais e plantadas, silvicultura, florestas nativas e lavouras perenes e anuais, e desse montante, a cana-de-açúcar, na safra 2009/10, ocupou em torno de 8,7 milhões de hectares, ou cerca de 0,9\% da superfície do Brasil, que produziu cerca de 612 milhões de toneladas de cana-de-açúcar (MARQUES, 2010, p. 56).

Com base nesses dados, constata-se que o aumento na produtividade da cana no país não comprometerá as áreas agro-alimentares, por conta do ganho genético, na mecanização e na expansão do plantio em áreas de pastagens não exploradas, caracterizando aos que contestam essa elevação pela oferta de cana a necessidade por um argumento mais ambiental do que por falta de alimentos.

De acordo com Nassar et al (2008, p. 64-66), a área cultivada com cana-de-açúcar, em 2008, foi de 8,5 milhões de hectares, sendo $85 \%$ na região Centro-Sul e 14,7\% na região Nordeste. Na região Centro-Sul (Paraná, São Paulo, Minas Gerais, Espírito Santos, Mato Grosso do Sul, Mato Grosso e Goiás, onde se concentram as principais unidades produtoras de etanol), a expansão da cana ocorre em áreas de pastagem. Isso se deve ao fato de que essas terras são mais baratas do que as terras ocupadas com outras culturas, e o investimento inicial significativamente menor do que o de limpeza e preparo de áreas ocupadas com vegetação nativa, inclusive em face da adaptabilidade e do alto teor de sacarose das mudas de cana corresponder melhor a essa região. Com relação à competição com a produção de alimentos, os autores também afirmam que não há razão para se acreditar que a recente expansão da cana-de-açúcar impactou negativamente na produção de alimentos, já que não houve redução da produção das culturas agrícolas cujas áreas foram deslocadas. Quanto à pecuária, constatase que, nos últimos anos, houve aumento do número de cabeças de gado por hectare, diminuindo a necessidade de áreas.

Na safra 2007/2008, a área plantada com cana-de-açúcar aumentou 653.700 hectares, um crescimento de $12 \%$ em comparação com a safra anterior. Desses, 140 mil hectares correspondem a terras onde antes se cultivavam grãos, como milho e soja (no total, a cana ocupou $0,4 \%$ da área total cultivada com grãos). De todo o crescimento de área plantada da última safra, $65 \%$ ocorreram em terras antes dedicadas à pecuária (pastagens). $\mathrm{O}$ avanço dos 
canaviais reduziu a área de pastagens do país em cerca de $0,2 \%$. A produção maior foi alcançada com uma expansão de apenas $1,1 \%$ na área plantada (CONAB, 2008).

Esse órgão registrou também que mais da metade da expansão do cultivo da cana-de-açúcar da safra 2007/2008 ocorreu no Estado de São Paulo. O Estado responde por 53,8\% das novas áreas plantadas. Mas as maiores taxas de crescimento foram encontradas em Minas Gerais, Goiás e Mato Grosso do Sul. Tal perspectiva ainda se intensifica ao avaliar, conforme dados da UNICA (2010), que para o Brasil os investimentos na construção de novas usinas são da ordem de US\$ 33 bilhões no período de 2008 a 2012, e estes com tecnologia produtiva mais avançada proporcionam maior produtividade. Em 2008, havia 340 usinas em funcionamento e 76 em processo de construção, e essa expansão se deflagra ao considerar que, desde 2005, 84 novas usinas entraram em produção na região Centro-Sul do país, revelando a expectativa que o setor defronta e que, certamente, a tecnologia flex, a produção de açúcar e os usos alternativos tiveram suas contribuições. Porém, intensificar o número de usinas na região Centro-Sul sem a preocupação de ter de dispersar investimentos em outras áreas do país, como, por exemplo, expandir as bases distribuidoras de combustíveis e novas refinarias, remete-se ao entendimento de que os preços ainda seriam distorcidos e mais vantajosos para os consumidores que estiverem na região Centro-Sul.

Sob esse aspecto, já há uma solução disciplinada para várias regiões do país, uma vez que a tecnologia flex fuel já tenha alcançado dimensões e escala produtiva, que não só proporcionou a transição de um combustível de origem fóssil (petróleo) para um combustível de fonte renovável (no Brasil, a cana-de-açúcar), como também permitiu um apelo ambiental muito forte, em que, embora o fator determinante seja do consumidor final, na hora de escolher o combustível que vai por no carro, há outras razões que determinam sua decisão de escolha, tal como a preocupação com o meio ambiente. 


\section{ASPECTOS METODOLÓGICOS}

Com base em referencial teórico acerca da formação de preços, verificou-se a existência da complexidade na prática dos preços como algo que se sugere para o mercado e que absorve ou se toma o preço praticado no mercado, cujos fatores tanto internos (por exemplo: custos) quanto externos (mercado, por exemplo: oferta) são relevantes na análise qualitativa e na identificação de variáveis que possam determinar a formação dos preços, o que motivou a escolha de uma metodologia baseada em estudos qualitativos e quantitativos, em que um complementa o outro em sua análise.

\subsection{Método e tipo de pesquisa}

A metodologia a ser utilizada para a realização desta pesquisa esclarece como se pretende tratar o problema colocado. Este estudo, conforme a definição de Moura (1978), é do tipo teórico-empírico, partindo de uma formulação teórica e, posteriormente, confrontando-a com os fatos reais, por meio de observação empírica.

O método proposto por este trabalho é o da pesquisa qualitativa, sendo complementado com a quantitativa. Essa integração da pesquisa qualitativa com a quantitativa, segundo Goldenberg (2005), permite que o pesquisador faça um cruzamento de suas conclusões de modo a ter maior confiança nos seus dados, os quais não são produtos de um procedimento específico ou de alguma situação particular. Nesse sentido, de acordo com Miles e Huberman ${ }^{4}$ (1994 apud GHAURI; GRONHAUG, 1995), a pesquisa qualitativa é adequada em estudos de assuntos complexos, como o comportamento humano ou organizacional, permitindo que o pesquisador obtenha informações muito mais detalhadas.

Afirma-se tal fato pelas observações de Godoy (1995), o qual menciona que a pesquisa qualitativa envolve a obtenção de dados descritivos sobre pessoas, lugares e processos interativos pelo contato direto do pesquisador com a situação estudada, procurando entender o fenômeno segundo a perspectiva dos sujeitos. Em contrapartida, nas observações de Parlett e Hamilton (1976), a pesquisa quantitativa possui uma característica experimental em análises estatísticas paramétricas ou multivariadas, como sendo a base da "boa" ciência. Em paralelo,

\footnotetext{
${ }^{4}$ MILES, M. B.; HUBERMAN, A. M. Qualitative Data Analysis: An Expanded Sourcebook. London: Sage, 1994.
} 
Richardson et al (1999) destaca que, no método quantitativo, o pesquisador vai se preocupar com a medição objetiva e a quantificação dos resultados.

Similarmente, Godoy (1995, p. 18) aponta que o método qualitativo proporciona uma grande diversidade de métodos de trabalho, estilos de análise e de apresentação de resultados e diferentes considerações quanto aos sujeitos. Entretanto, essa abordagem tradicional mostra certa limitação quando lida com problemas mais complexos em situações do mundo real com ambientes não controlados e confusos, como é o caso do problema desta pesquisa acerca da formação dos preços do combustível etanol hidratado. Daí a necessidade de observar o método quantitativo, e não apenas o qualitativo, na tentativa de apresentar a formação de preços do etanol hidratado.

A abordagem qualitativa na presente pesquisa tem por premissas as entrevistas abertas, que permitem observação e análise holística do mercado do etanol hidratado. Por se tratar de uma entrevista aberta, tal técnica tem sua finalidade exploratória objetivando o detalhamento dos conceitos relacionados à diferenciação do preço do etanol e do setor sucroenergético. Segundo Lakatos e Marconi (1991, p. 44), a técnica de entrevistas abertas atende às finalidades exploratórias, em que o entrevistador introduz o tema, e o entrevistado tem liberdade para discorrer sobre o tema sugerido. A interferência do entrevistador deve ser a mínima possível, devendo este assumir predominantemente uma postura de ouvinte, não estabelecendo a aplicação formal de questionários. Ou seja, as perguntas devem ser respondidas dentro de uma conversação informal.

Nesse aspecto, esta pesquisa permitirá um corte longitudinal possibilitando delimitar os seguintes objetivos de pesquisa: explicar a formação do preço do etanol hidratado nas bombas dos postos de combustíveis (objetivo principal) e destacar em que região do país o etanol hidratado é vantajoso em relação à gasolina $\mathrm{C}$ (objetivo secundário). Assim, o método escolhido para esta pesquisa é o qualitativo, com uma metodologia não estruturada, exploratória, que proporciona reflexões e compreensão do contexto do problema, sendo posteriormente complementado com o método quantitativo. O qualitativo é utilizado para casos em que se quer explorar um problema e seus dados podem ser considerados conclusivos, mas não generalizáveis à população-alvo. Para evidenciar a formação e a relação de preços de combustíveis no mercado interno, esta pesquisa também contará com o método 
quantitativo, o qual terá como objetivo quantificar os dados e generalizar os resultados da amostra para a população-alvo, utilizando um número de variáveis significativas, relacionadas a preços praticados na revenda.

Cabe enfatizar que, neste estudo, o etanol anidro não emerge como mais um fator na disponibilidade do hidratado e, portanto, na oferta que afeta seu preço. Parte-se do pressuposto de que o primeiro é absorvido pela Petrobras na constituição da gasolina C, e o segundo é vendido diretamente ao consumidor nos postos. Entretanto, tanto o anidro quanto o hidratado possuem relação na oferta, uma vez que, quanto mais anidro for adicionado na gasolina A para tornar-se gasolina $\mathrm{C}$, menos disponibilidade haverá de etanol hidratado para o mercado interno, já que compartilha a mesma matéria-prima, qual seja, o caldo de cana-deaçúcar.

Com relação ao tipo de pesquisa, considera-se que o teor investigativo desta pesquisa é do tipo exploratório, descritivo e explicativo, que, segundo Gil (2007, p. 110), objetiva aprofundar o conhecimento sobre um determinado problema para torná-lo mais explícito ou para a construção e delimitação das hipóteses, buscando descrever as características de um fenômeno ou população predeterminada e sua relação entre as variáveis. Nota-se que a pesquisa será também explicativa, conforme o autor, por preocupar-se em identificar as relações de causa e efeito entre as variáveis estudadas. Ainda para ele, as pesquisas exploratórias são desenvolvidas com o objetivo de proporcionar visão geral, de tipo aproximativo, acerca de determinado fato. Esse tipo de pesquisa é realizado especialmente quando o tema escolhido é pouco explorado e quando se torna difícil formular sobre ele hipóteses precisas e operacionalizáveis, cabendo a este estudo o desafio de trilhar hipóteses que corroboram as observações qualitativas exploradas.

Para Cooper e Schindler (2003, p. 39-41), quando um pesquisador procura o entendimento sobre a natureza geral de um problema, o tipo de pesquisa mais adequada é a exploratória. Em outras palavras, no presente estudo, não há uma estrutura rígida; os métodos são flexíveis, não estruturados e qualitativos. É um tipo de pesquisa que visa prover o pesquisador de maior conhecimento sobre o tema ou problema de pesquisa em perspectiva. Por se caracterizar como um estudo inicial, o pesquisador busca identificar hipóteses que servirão para comprovação em estudos futuros. 
Há que se considerar, segundo Cooper e Schindler (2003, p. 39-41), que, apesar do valor óbvio da pesquisa exploratória, os pesquisadores dão menos atenção à exploração do que deveriam, pois há fortes pressões por respostas rápidas. Assim, este estudo é do tipo exploratório, embasado no interesse de aumentar o conhecimento sobre a formação dos preços do combustível etanol hidratado no mercado brasileiro.

Segundo Hair et al (2005a, p. 152), a pesquisa exploratória é útil quando o responsável pelas decisões dispõe de poucas informações. Quando bem conduzida, abre uma janela para percepções e comportamentos. A pesquisa exploratória é útil na identificação de práticas inovadoras de produção e administração. O mesmo entende-se em Patton ${ }^{5}$ (1986 apud ALVES, 1991, p. 22), que afirma que descrições detalhadas de situações, eventos, pessoas, interações e comportamentos observados, citações literais do que as pessoas falam sobre suas experiências, atitudes, crenças e pensamentos, bem como trechos ou íntegras de documentos, correspondências, atas ou relatórios de casos caracterizam a natureza predominante dos dados qualitativos.

Portanto, adotou-se para o presente estudo o método qualitativo e quantitativo, sendo a pesquisa do tipo descritiva e explicativa, uma vez que busca descrever um fenômeno específico com o objetivo de conhecer sua natureza, os processos que o compõem ou que nele ocorrem. É, também, de natureza exploratória, pois objetiva proporcionar uma visão geral do fenômeno pesquisado, que é identificar a formação dos preços do etanol hidratado no mercado interno por meio da imersão do pesquisador no contexto.

\subsection{Esquema e característica de desenvolvimento da pesquisa}

A pesquisa apresentada nesta tese será, portanto, desenvolvida por métodos qualitativo e quantitativo, sendo que o quantitativo possui um tratamento estatístico por meio de regressão linear múltipla como forma de corroborar as principais variáveis explicativas na formação de preços do etanol hidratado, e também pela Anova, que permite observar as diferenças de preços no mercado interno e identificar em que região o etanol hidratado se posicionou como vantajoso em relação à gasolina $\mathrm{C}$.

\footnotetext{
${ }^{5}$ PATTON, M. Q. Qualitative Evaluation Methods. 7. ed. Beverly Hills, CA: Sage, 1986.
} 
O esquema que delimitou as etapas de investigação foi desenvolvido a partir da Figura 6, que ilustra a metodologia para levantar e analisar os dados, cujas reuniões de pesquisas e as entrevistas, se estenderam de forma aberta na finalidade de capturar informações relevantes que pudessem auxiliar na quantificação e na coleta de dados e de informações para os resultados da pesquisa.

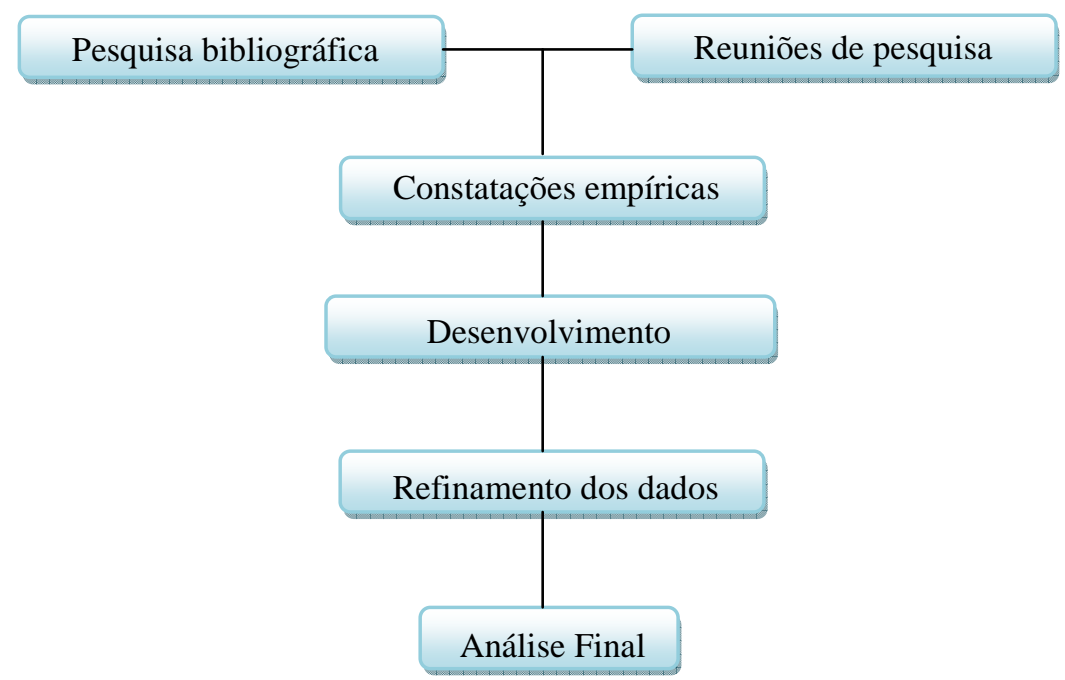

Figura 6 - Esquema síntese do processo de desenvolvimento da metodologia da pesquisa Fonte: desenvolvido pelo autor.

Em face do tipo qualitativo de pesquisa a ser abordado, admite-se que a grande vantagem para o estudo da formação de preços do combustível etanol na revenda é a riqueza dos detalhes a serem obtidos, da sua abordagem holística e do fluxo temporal das transformações. Assim, em sua característica de estudo, buscar-se-á, de uma forma exploratória, teórica e empírica, descrever a formação de preços do etanol hidratado e sua respectiva vantagem no posto de revenda, dentre as macrorregiões do país, a partir do entendimento das relações complexas acerca da tecnologia, estrutura, regulamentos e meio ambiente, os quais beneficiam a abordagem quantitativa na constituição de variáveis explicativas.

A dedução neste estudo é decorrente das abordagens qualitativas levantadas, enquanto a indução se baseia nos dados quantitativos. Ou seja, a magnitude das diferenças de preços será corroborada quantitativamente pelos dados colhidos, podendo estes serem inferidos estatisticamente. Com relação às abordagens qualitativas no que compete à cadeia produtiva do etanol hidratado, o aporte teórico diz respeito à formação de preços, tecnologias, estruturas e mercado. Estes servirão de base para sustentar os componentes que explicam a formação de preços do combustível etanol no mercado interno. 
Sendo assim, o presente trabalho possui características que Cooper e Schindler (2003) definem como movimento duplo do pensamento científico, integrando pensamentos dedutivos com indutivos, ora aqui tratados por meio dos métodos da regressão linear múltipla seguida do teste de análise de variância (Anova) utilizando o pós-teste de Tukey. Ainda para esses autores, o pensamento dedutivo consiste em chegar a uma conclusão a partir da verificação de premissas previamente elaboradas. Uma dedução é válida desde que seja impossível que a conclusão seja falsa se as premissas forem verdadeiras. Já o pensamento indutivo permite ao pesquisador fazer inferências e generalizações sobre o todo a partir da observação de particularidades.

Nesse sentido, a pesquisa apoia-se nos estudos realizados por Lakatos e Marconi (2000), que admitem ou generalizam um fato sem a necessidade de ser demonstrado ou justificado, bastando apenas para este presente estudo a constatação ou não das diferenças de preços dos combustíveis em questão, bem como a sua respectiva significância quanto à vantagem de um em relação ao outro. Para elas, enquanto o pensamento indutivo permite ao pesquisador fazer inferências e generalizações sobre o todo a partir da observação de particularidades, o pensamento dedutivo consiste em chegar a uma conclusão a partir da verificação de premissas previamente elaboradas. Assim, os argumentos indutivos aumentam o conteúdo das premissas, ao passo que os argumentos dedutivos sacrificam a ampliação do conteúdo para atingir a certeza.

Este trabalho possui características dedutivas devido aos níveis de detalhes consolidados, que são múltiplos, no mercado do etanol, e interferem na formação de preços, o que leva à problemática da pesquisa. Além disso, possui características indutivas, com base em uma amostra de dados com 14 variáveis independentes, e estes se correlacionam com preços do combustível etanol praticados no posto de revenda; aos quais serviram para confirmar suas relações na formação de preços no mercado interno, cabendo inicialmente às características dedutivas, por parte da análise qualitativa, apontar variáveis que explicam tais formações de preços. Contudo, cabe ressaltar que a metodologia não se limita a um conjunto de procedimentos, e seus limites e pressupostos teóricos devem ser testados, confrontados e avaliados continuamente. 


\subsection{Procedimentos para coleta e análise de dados}

Para a realização deste estudo, foram coletados dados secundários e primários. O primeiro passo foi a busca por dados secundários. Cooper e Schindler (2003, p. 37) argumentam que o primeiro passo em um estudo exploratório é a busca de literatura secundária. Estudos feitos por terceiros, com seus próprios objetivos, representam, portanto, dados secundários. Os dados secundários são divididos, segundo Malhotra (2001), em:

a) dados internos - gerados na instituição em que está sendo realizada a pesquisa;

b) dados externos - gerados por fontes externas à instituição pesquisada.

Ademais, tem-se que os dados secundários são aqueles coletados por pessoas ou agências para outros propósitos que não a resolução do problema específico da pesquisa em questão (AAKER et al, 2004). Esses dados ajudam o pesquisador a estabelecer o embasamento teórico geral que lhe serve de apoio (TRIVIÑOS, 1987).

Os dados secundários foram coletados por meio de contatos diretos realizados na ANP, Sindicom, Orplana, Sincopetro, MAPA, Denatran, Cepea/Esalq, Copersucar, Usinas, Magnet Marelli e UNICA, consistindo em material explicativo e apresentações. Já os dados externos são materiais publicados e dados disponíveis na Internet. O instrumento de pesquisa utilizado para a realização das entrevistas com os gestores das referidas instituições foi uma entrevista aberta, o que permitiu direcionar melhor análise ao objeto de pesquisa e delimitar melhor o material a ser consultado, tais como: pesquisa documental em sites e materiais institucionais de especialistas do setor e pesquisa bibliográfica sobre os temas. Para Triviños (1987), a entrevista aberta é um dos instrumentos mais decisivos para estudar os processos e produtos nos quais está interessado o investigador qualitativo. Em conformidade, Alencar (2000) afirma que a vantagem desse tipo de entrevista é permitir que o entrevistado manifeste suas opiniões, seus pontos de vista e seus argumentos, fornecendo informações para os rumos da pesquisa.

Quanto à análise da entrevista, a metodologia consistiu na análise de conteúdo. Lakatos e Marconi (1999, p. 42) consideram que essa técnica de análise de conteúdo permite posteriormente a uma melhor análise do conteúdo de livros, revistas, jornais e documentos pessoais, como discursos e diários, entrevistas abertas entre outros, que norteiam a etapa secundária da pesquisa. 
Já os dados primários, que representam a segunda fase, são aqueles que são coletados com o propósito de atender às necessidades específicas da pesquisa (MATTAR, 2001, p. 22). Eles são obtidos pelo pesquisador conforme os procedimentos sugeridos no tipo de pesquisa e no método de estudo escolhidos. Este trabalho reuniu os preços praticados no ano de 2009 dentre as macrorregiões do país (Norte, Nordeste, Centro-oeste, Sul e Sudeste) por meio de postos de revenda; e, também, dados quantitativos levantados pela ANP, Sindicom, Orplana, UNICA, MAPA e Denatran, quanto às práticas de preços do açúcar, etanol e da gasolina $\mathrm{C}$, tributos, fretes, custos, capacidade de abastecimento nas distribuidoras, número de postos revendedores, número de postos bandeira branca ${ }^{6}$, número de distribuidoras, número de usinas de açúcar e etanol, preço do açúcar para exportação, produção de etanol e açúcar e frota de carros flex, para a análise quantitativa do estudo.

O procedimento metodológico na análise quantitativa será a construção de um modelo de regressão linear múltiplo, em que a variável dependente é o preço do etanol na revenda (posto de combustível), e as variáveis independentes (variáveis explicativas) serão:

i. $\quad$ preços na distribuidora $\mathrm{R} \$(1)$;

ii. $\quad$ preço pago ao produtor $\mathrm{R} \$(1)$;

iii. preço da gasolina C R $\$(1)$;

iv. preço do açúcar tipo exportação (t);

v. número de postos revendedores;

vi. número de postos bandeira branca;

vii. número de distribuidoras;

viii. $\quad$ capacidade nominal de armazenagem de etanol $\left(\mathrm{m}^{3}\right)$;

ix. produção de etanol $\left(10^{3} \mathrm{~m}^{3}\right)$;

x. $\quad$ produção de açúcar $(\mathrm{t})$;

xi. frota de carros flex;

xii. frete $\mathrm{R} \$(1)$;

xiii. impostos sobre o preço final pago na bomba $\mathrm{R} \$(1)$;

xiv. custos de produção de etanol hidratado $\mathrm{R}$ (1).

Outra ferramenta estatística utilizada para atingir o objetivo da relação econômica do

\footnotetext{
${ }^{6}$ Quando não há marca comercial de nenhuma distribuidora, no entanto o posto deve identificar em cada bomba abastecedora, o distribuidor fornecedor do respectivo combustível.
} 
combustível etanol no motor flex, quanto ao teto dos $70 \%$ do preço do etanol hidratado em relação à gasolina C, foi a Análise de Variância (ANOVA).

Cabe enfatizar que não coube se utilizar da metodologia MANOVA neste estudo, por não se tratar de um modelo linear generalizado. Ou seja, seu conjunto de dados obtidos por unidades de federação no ano de 2009 não permite o ajuste de um modelo linear generalizado, pois se trata de uma amostra pequena, o que implicaria nos graus de liberdade para o ajuste do modelo, e também pelo fato dos dados serem baseados em médias, o que reduz a precisão das medidas. Nesse aspecto, adotou-se a utilização da Anova como mais aderente quanto à confiabilidade dos resultados obtidos. Para testar diferenças entre as macrorregiões na relação preço da gasolina $\mathrm{C}$ versus preço do etanol hidratado, adotou-se o teste de análise de variância para amostras independentes (ANOVA) com o pós-teste de Tukey. Por conseguinte, o procedimento com o aspecto qualitativo abordado neste estudo, permite compreender as inferências à formação de preços.

Desse modo, a presente pesquisa apresenta duas fases sustentadas pelos métodos qualitativos e quantitativos. A primeira fase - primária - é exploratória, sustentada por dados secundários para uma melhor compreensão do tema que constitui as variáveis explicativas da formação de preços; e a segunda fase - secundária - com dados quantitativos que contribuem para a análise indutiva do estudo, ou seja:

a) Fase primária - estudo qualitativo da formação de preços e do mercado do etanol que configuraram as variáveis explicativas.

b) Fase secundária - investigações acerca de dados quantitativos que explicam que variáveis são mais explicativas à formação de preços e a caracterização sob quais regiões o preço do etanol hidratado tem sido apresentado no posto de revenda como vantajoso em relação à gasolina $\mathrm{C}$.

Tais levantamentos feitos por meio de fontes secundárias permitiram uma fase de profundidade analítica sob o objeto de pesquisa que contribuíram para o desenvolvimento das inferências e conclusões. É oportuno enfatizar que os preços médios do etanol hidratado majorados nos postos de revenda (atribuídos na análise quantitativa do estudo como variável dependente) foram extraídos da ANP. Esses dados perfazem a metodologia, que contempla 
preços de postos bandeira branca e bandeirados (postos bandeirados são os que possuem marca de uma determinada distribuidora). Essa metodologia serve, portanto, para efeitos de cálculo de preços médios publicados no levantamento de preços e de margens de comercialização de combustíveis, disponibilizado no sítio eletrônico desta Agência, tampouco há algum critério que estabeleça diferenciação no processo de seleção de postos revendedores (sejam eles bandeirados ou de bandeira branca) a serem pesquisados.

No tocante aos procedimentos metodológicos escolhidos para o desenvolvimento desta pesquisa, eles serão divididos em duas fases que buscam responder às questões definidas e atender aos objetivos propostos por este trabalho:

1 - revisão da literatura da formação de preços, da cadeia produtiva do etanol, determinantes do atual mercado do combustível etanol, estrutura tecnológica, produtiva e distributiva acerca do etanol;

2 - estudos da formação e das diferenças dos preços do combustível etanol hidratado no mercado brasileiro, por meio da regressão linear múltipla e Anova.

A Figura 7 resume o procedimento metodológico utilizado e o seu relacionamento com os objetivos propostos nesta pesquisa. 


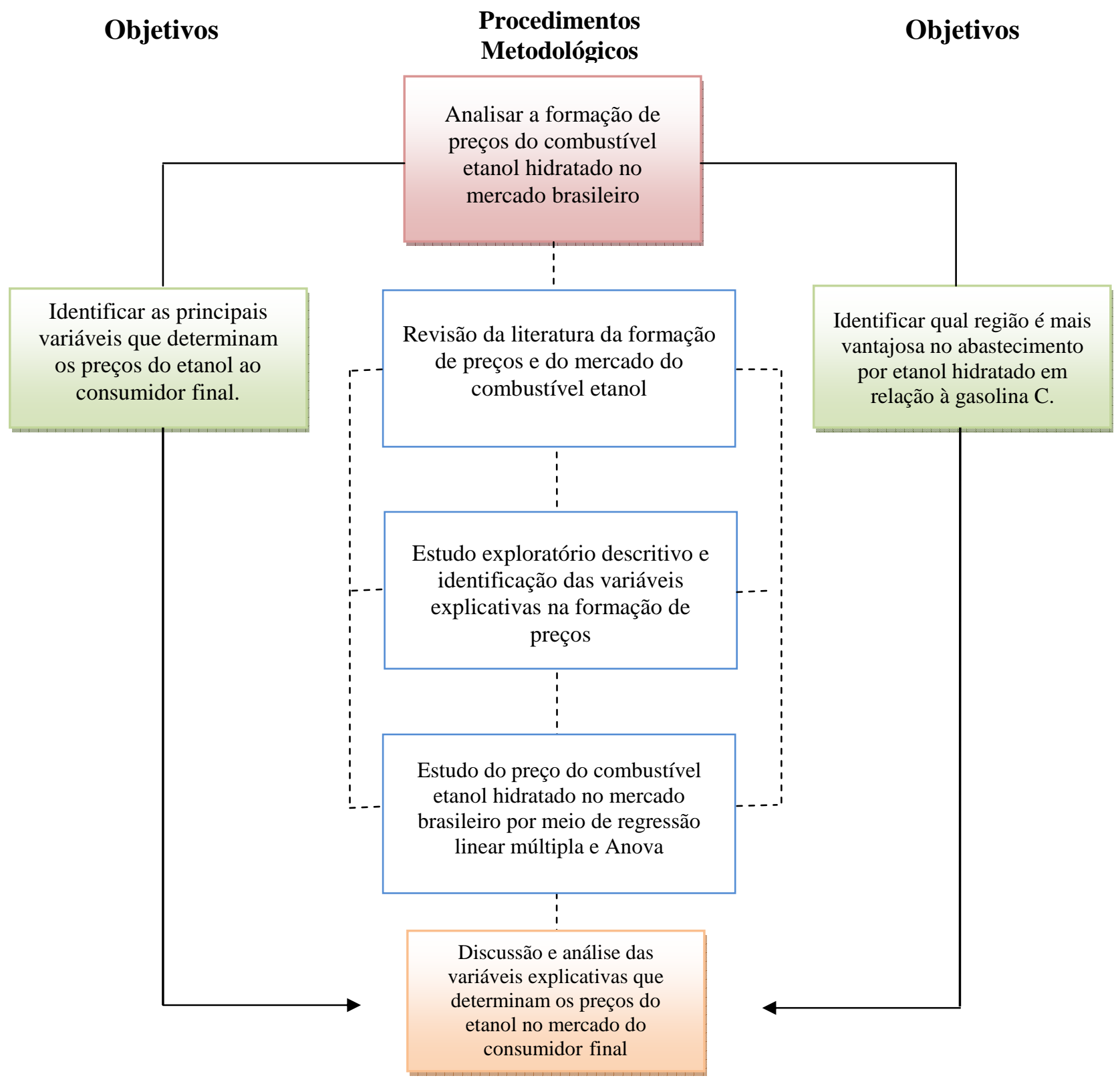

Figura 7 - Relação entre os Objetivos e os Procedimentos Metodológicos Fonte: desenvolvido pelo autor.

Nessa figura, encontra-se a estrutura da pesquisa relacionando os objetivos aos procedimentos metodológicos adotados. Segundo Gil (2007, p. 19), pesquisa é um procedimento racional e sistemático, que tem como objetivo proporcionar respostas aos problemas que são propostos.

Pode-se observar que, além de ser uma pesquisa com uma abordagem qualitativa e quantitativa em busca da formação de preços do etanol hidratado, este estudo é também do tipo exploratório, uma vez que associa sua formação às diferenças de preços do combustível etanol em relação à gasolina $\mathrm{C}$ no mercado brasileiro. Ou seja, versa sobre um tema pouco pesquisado e sobre o qual ainda não se acumulou uma bibliografia significativa; tal fato 
possibilita corroborar seus resultados às diferenças de preços pela aplicação da ferramenta estatística - regressão linear múltipla e Anova.

Portanto, a aplicação metodológica baseou-se a partir dos objetivos específicos propostos:

1- Analisar a formação de preços do combustível etanol hidratado no mercado brasileiro;

2- Identificar as principais variáveis que determinam os preços do etanol ao consumidor final;

3- Identificar qual região é mais vantajosa no abastecimento por etanol hidratado em relação à gasolina $\mathrm{C}$.

Para atender aos objetivos 1 e 2, foi realizado um modelo de regressão linear múltiplo, empregado para estudar a relação entre uma única variável dependente e diversas variáveis independentes (explicativas). Esse modelo tem como pressuposto que seus resíduos tenham distribuição normal com média 0 e variância constante (NETER et al, 1990, p. 11). Os resultados foram obtidos com o auxílio do software $\mathrm{SAS}{ }^{\circledR}$ 9.0, por meio do PROC RE.G ${ }^{7}$.

Para atingir o objetivo 3, foi proposta a análise de variância (ANOVA). Esta metodologia baseia-se em particionar a variância total de uma determinada resposta (variável dependente) em duas vertentes: a primeira relacionada ao modelo de regressão (no caso, entre grupos) e a segunda relacionada aos resíduos (erros) (dentro dos grupos). Quanto maior for a primeira em relação à segunda, maior é a evidência da diferença entre as médias dos grupos (MONTGOMERY, 2000, p. 55). Esse modelo tem como pressuposto que seus resíduos tenham distribuição normal com média 0 (zero) e variância constante. Em seguida, foi realizado o pós-teste de Tukey, a fim de detectar quais as regiões que apresentavam diferenças significativas. Os resultados foram obtidos com o auxílio do software SAS® 9, através da PROC GLM ${ }^{8}$.

Diante da problemática acentuada na pesquisa (Como se forma o preço do etanol hidratado?),

\footnotetext{
${ }^{7}$ SAS® 9.0, representa um sistema integrado de software que possibilita análises estatísticas; PROC RE.G, serve para ajustar uma regressão linear com várias opções de diagnósticos e diversos métodos para seleção de modelos.

8 PROC GLM, utilizado para ajustar modelos lineares gerais permitindo fazer análise de variância para dados desbalanceados.
} 
foi possível constatar, por meio da pesquisa quantitativa, utilizando a regressão linear múltipla, que modelo se constitui dentre as variáveis independentes propostas para a formação de preços. Segundo Malhotra (2001) e Selltiz et al (1974), tal campo de investigação se faz viável em casos nos quais é necessário definir o problema com maior precisão, identificar cursos relevantes de ação ou obter dados adicionais antes que se possa desenvolver uma abordagem. Entretanto, a finalidade que mais se encaixa nesta pesquisa é estabelecer prioridades para pesquisas posteriores no que compete a impactos futuros decorrentes do uso do combustível etanol hidratado.

Ainda com base na Figura 7, buscar-se-á extrair conclusões relevantes para a formação de preços do mercado do etanol hidratado após a criação do flex. Tais objetivos permitirão investigações futuras da possibilidade de o flex ser substituído pelo híbrido flex, e até mesmo nortearão campos de investigação quanto à expectativa de o motor ora fabricado em larga escala à combustão interna ser substituído pelo motor elétrico.

Outra possibilidade no campo de investigação que o referido estudo pode contribuir é quanto à substituição do veículo a etanol/gasolina pelo veículo a diesel/biodiesel. Ainda há que se considerar que tecnologias na produção de plásticos, tendo o etanol como fonte de matériaprima, podem surgir como um mercado promissor, o que afetará a oferta do combustível etanol ou mesmo expandirá a sua produção. Se, na ordem tecnológica, o etanol ao longo dos tempos sofrer alterações dentre as possibilidades de usos, deve-se admitir, então, a necessidade de uma expansão e ganhos de produtividade da cana-de-açúcar, em virtude de esta ser a principal matéria. Ou seja, há prospecções tecnológicas que a matéria-prima canade-açúcar pode oferecer, o que, por sua vez, pode comprimir a oferta de etanol e o seu respectivo abastecimento no mercado interno.

\subsection{Delineamentos das hipóteses e variáveis de pesquisa}

Neste tópico, o delineamento das hipóteses serve apenas para confirmar a asserção preliminar de que há diferenças estatisticamente significativas de preços entre as regiões. Sem essa prova, não se pode afirmar que há um problema de diferença relativa de preços regionais.

Desse modo, o cálculo da Anova permite a verificação do conhecimento científico. Neste 
estudo, os dados quantitativos foram coletados na ANP com relação aos preços médios do combustível etanol hidratado e gasolina C praticados no posto de revenda no ano de 2009. Esses dados servirão como base para sustentar a hipótese inicial, ou nula, de que não há diferenças de preços nas macrorregiões do país. Em contrapartida, o tratamento da hipótese principal é de que há diferença de preço do etanol hidratado entre as macrorregiões, cabendo avaliar sua significância e vantagem em relação à gasolina $\mathrm{C}$ ao longo do período referido.

De acordo com Martins (1994, p. 19), a formulação de hipóteses representa uma ferramenta poderosa para o avanço do conhecimento, porque, embora formuladas pelo homem, podem ser testadas e mostradas como provavelmente corretas ou incorretas independentemente dos valores e crenças do homem. A aceitação ou rejeição das hipóteses permite atingir o objetivo proposto pelo trabalho científico, desde que o conhecimento científico possua a característica de verificabilidade conjuntamente às abordagens qualitativas aqui estudadas, de maneira que se possam explicar as razões das diferentes práticas de preços do combustível etanol nas variadas regiões do mercado interno.

De acordo com Lakatos e Marconi (1991, p. 59), a hipótese de trabalho - usada nos estudos de caráter exploratório ou descritivo, em que é dispensável sua explicitação formal - é necessária para que a pesquisa apresente resultados úteis, ou seja, atinja níveis de interpretação mais altos.

De posse da problemática, dos objetivos a serem alcançados e das razões que justificam este estudo, que se consagra como do tipo exploratório-descritivo, assumem-se as seguintes hipóteses para esta pesquisa relativas às macrorregiões do país:

Ho (hipótese nula) - não existe relacionamento significativo nas diferenças de preços entre as variáveis etanol hidratado e gasolina $\mathrm{C}$.

H1 (hipótese alternativa 1) - existe um relacionamento significativo nas diferenças de preços entre as variáveis etanol hidratado e gasolina $\mathrm{C}$.

Ademais, as diferenças nos preços do combustível etanol nos postos de revenda explicam-se pelas características qualitativas, significativas à sua formação de preços e intrínsecas à sua 
respectiva região geográfica, dentre as quais algumas variáveis norteiam como razões explicativas. Dentre as possíveis variáveis explicativas, destacaram-se para o estudo apenas 14 variáveis compreendidas como independentes, e que constituíram para elaboração de um modelo proposto para explicar a formação de preços pela ferramenta estatística - regressão linear múltipla. Dentre as variáveis explicativas, foram identificadas as seguintes:

Tabela 8 - Variáveis explicativas da diferenciação dos preços do etanol hidratado

\begin{tabular}{|c|c|c|c|c|}
\hline Tecnológicas & Estruturais & Políticas & Econômicas & Ambientais \\
\hline $\begin{array}{l}\text { - Flex fuel. } \\
\text { - Mecanização } \\
\text { na colheita. } \\
\text { - Melhoria } \\
\text { genética. } \\
\text { - Melhoria na } \\
\text { turbidez do } \\
\text { caldo. } \\
\text { - Eteno. } \\
\text { - Farneceno. } \\
\text { - Híbrido. }\end{array}$ & $\begin{array}{l}\text { - Logística. } \\
\text { - Tancagem. } \\
\text { - Usinas/Destilarias. } \\
\text { - Distribuidoras. } \\
\text { - Centros coletores e } \\
\text { refinadores. } \\
\text { - Geografia da } \\
\text { produção e } \\
\text { distribuição. } \\
\text { - Número de postos } \\
\text { revendedores. } \\
\text { - Número de postos } \\
\text { bandeira branca. } \\
\text { - Número de } \\
\text { distribuidoras. } \\
\text { - Capacidade de } \\
\text { armazenagem. } \\
\text { - Frota de carros flex. } \\
\text { - Número de usinas de } \\
\text { açúcar e etanol. } \\
\text { - Frete. } \\
\text { - Frota. }\end{array}$ & $\begin{array}{l}\text { - Proálcool. } \\
\text { - Sindicatos. } \\
\text { - Associações. } \\
\text { - Normatizações. }\end{array}$ & $\begin{array}{l}\text { - Interesses } \\
\text { regionais. } \\
\text { - Custos de } \\
\text { produção. } \\
\text { - Preços na } \\
\text { revenda. } \\
\text { - Preços na } \\
\text { distribuidora. } \\
\text { - Preços no } \\
\text { produtor. } \\
\text { - Preço da } \\
\text { gasolina C. } \\
\text { - Preço do } \\
\text { açúcar. } \\
\text { - Produção de } \\
\text { etanol. } \\
\text { - Produção de } \\
\text { - } \text { açúcar. } \\
\text { Impostos. }\end{array}$ & $\begin{array}{l}\text { - } \begin{array}{l}\text { Energia } \\
\text { renovável }\end{array} \\
\text { - } \begin{array}{l}\text { Segurança } \\
\text { alimentar. }\end{array}\end{array}$ \\
\hline
\end{tabular}
Fonte: desenvolvido pelo autor.

Em seguida, o teste de hipóteses entre os preços do etanol hidratado em relação à gasolina $\mathrm{C}$, na revenda, objetiva produzir inferências para a população objeto, macrorregiões, a partir das amostras de preços médios obtidos na ANP, sendo que, para a regressão, a hipótese é que existe ao menos uma variável que interfere no preço de revenda do etanol (H1).

Admite-se que um teste de hipóteses consiste em um problema de decisão, em que se deve escolher uma entre as duas hipóteses. A realização do teste de hipóteses permite apresentar o nível de significância com que os preços dos combustíveis se diferem entre as macrorregiões, podendo estabelecer até mesmo quais estados têm apresentado maior vantagem do etanol hidratado em relação à gasolina $\mathrm{C}$ com base no parâmetro de decisão 0,7 . Ou seja, uma vez 
que o etanol hidratado estiver 0,7 (ou até $70 \%$ ) de seu preço abaixo da gasolina $\mathrm{C}$, irá revelar que seu abastecimento é vantajoso, desde que os veículos sejam flex.

Nesse sentido, a viabilidade do uso do etanol hidratado dá-se a partir de uma razão simples entre os preços do etanol hidratado e da gasolina C. Ou seja, a relação é expressa por:

Etanol Hidratado (até 0,7 é vantajoso o uso do etanol hidratado).

Gasolina C

Em outras palavras, há uma razão simples entre os preços, e não uma variação de preços, pois associa-se isso ao fator desempenho do motor como delimitador na ordem econômica de decisão por qual combustível utilizar no caso dos veículos flex. Assim, só é viável o abastecimento de etanol hidratado se o seu preço for inferior a $70 \%$ do preço da gasolina $\mathrm{C}$, uma vez que há perda de desempenho com um litro de etanol em comparação ao uso de um litro de gasolina C. O resultado dessa relação possibilita a escolha de abastecimento, considerando que a tomada de decisão é exclusiva para veículos flex. A partir daí, é possível demonstrar em que região o etanol se demonstrou vantajoso pela referência comparativa de preços 0,7 . Em relação à hipótese $\mathrm{H}_{0}$, esta aparenta não ser plausível, já que os dados dos preços do combustível etanol nas macrorregiões posicionados pela ANP espelham tal efeito de diferenciação; porém, a magnitude e a intensidade serão testadas e apontadas, bem como será investigada a existência de vantagens do consumo do etanol hidratado em relação à gasolina C. Essa analítica é feita no Capítulo seguinte, e já no Capítulo 6, tal análise será corroborada com o uso da ferramenta estatística Anova.

Tomando-se como resultado esperado a confirmação de $\mathrm{H}_{1}$ e sua respectiva análise desempenhada no Capítulo 6, pode-se-á observar o cumprimento do objetivo geral do trabalho (a formação de preços do etanol hidratado e o estabelecimento das vantagens no abastecimento do etanol hidratado entre as macrorregiões). Vale destacar que, após a caracterização dos determinantes de preços do etanol, os quais justificam suas diferenças no mercado interno, existe a possibilidade de não se confirmar $\mathrm{H}_{1}$, o que também ofereceria substrato para a proposição deste estudo, que, no caso, indicaria a inadequação de suas perspectivas como aporte teórico. 
Portanto, a hipótese $\mathrm{H}_{1}$ possibilitará avaliar a magnitude e a intensidade dos preços do combustível etanol hidratado nas macrorregiões brasileiras, permitindo, posteriormente, associar possíveis variáveis que norteiam a formação e a explicação das diferenças de preços do etanol hidratado. Nesse sentido, o objetivo deste tipo de estudo é procurar padrões, ideias ou hipóteses, em vez de apenas testar ou confirmar uma hipótese comparativamente à outra, para que se possa arbitrar que uma seja falsa e a outra verdadeira. Assim, optou-se por investigar se $\mathrm{H}_{0}$ e $\mathrm{H}_{1}$ se confirmam ou não, para que se possa, então, associar às possíveis causas explicativas quanto à formação e às razões das diferenças do preço do etanol hidratado na revenda. Dessa forma, a formulação de hipóteses está ligada aos objetivos e problemas da pesquisa. 


\section{DINÂMICA DOS PREÇOS DO ETANOL HIDRATADO}

Esta seção aborda de forma descritiva e exploratória a dinâmica dos preços do etanol hidratado no mercado brasileiro, apresentando informações necessárias para dar base às discussões das próximas seções. Além de descrever a dinâmica dos preços analisando-os em níveis indutivos e qualitativos, será feita uma apresentação de como se dá a formação de preço final do produto, conforme será explicado a seguir.

\subsection{Oferta e demanda}

A dinâmica da oferta do etanol hidratado contempla um cenário amplamente favorável para o setor, devendo estimular o aumento da capacidade de processamento que contribui para reduzir, ainda mais, os custos de produção do etanol. Suas peculiaridades produtivas e o fato de o setor encontrar-se desregulamentado é que promovem a complexidade, pois ele não consegue alinhar seus objetivos estratégicos com as expectativas do governo e da população. Tal fato gera a necessidade por desenvolver uma estrutura de governança sólida e voltada para a competitividade e atendimento das demandas dos produtos que oferta, de modo sustentável para o negócio; do contrário, a volatilidade produtiva irá ofertar aquém das necessidades no abastecimento do mercado interno de etanol hidratado, implicando em oscilações recorrentes nos preços.

Diferentemente da regulação estatal intensa dos anos 1970 e 1980, o setor necessita desenvolver uma estrutura de governança articulada com o Estado e suas agências públicas, para evitar situações indesejadas como a escassez do etanol em épocas de entressafra e que abalam a reputação do setor diante dos consumidores ao perceberem as intensas oscilações nos preços praticados na revenda.

\footnotetext{
Para lidar com o novo ambiente de livre mercado, cresceu a articulação de interesses entre os industriais do açúcar e do etanol (via associações de interesses), visando aumentar o poder de negociação da categoria no processo de formulação das políticas públicas estabelecidas para o setor. Esses aspectos acabaram modificando a estrutura de governança (coordenação) no setor sucroenergético, já que, com o afastamento do Estado da regulação, as organizações de interesses foram obrigadas a reformularem-se, redefinindo suas metas e suas formas de organização e atuação. (MAPA, 2007, p. 94-95).
}

Conforme a Consecana (2010), o custo da matéria-prima, cana-de-açúcar, para produzir etanol, encontra-se em torno de $60 \%$, ao qual estabelece um modelo que dita a remuneração do produtor, calculada mensalmente com base no quilograma médio de Açúcar Total 
Recuperável (ATR), levando em conta também a qualidade da cana, o mix de produção das usinas e os preços alcançados tanto no mercado interno quanto no externo pelos produtos açúcar e etanol. Esse modelo não concebe à coordenação produtiva entre estratégias dos produtores, governo e população, prevalecendo interesses mercadológicos nas mesas de negociações. Apesar de ser uma porcentagem relativamente significativa na formação dos preços do etanol (esta poderá ser constatada na análise quantitativa deste estudo, capítulo seguinte), o setor enseja não ser suficiente para remunerar adequadamente os fornecedores, uma vez que a incerteza em relação ao mix de produção das usinas não se encontrar alinhada aos preços do açúcar ou etanol alcançados no mercado. Ou seja, as usinas, em seu mix de produção (produzir açúcar e/ou etanol), declaram menor produção do produto com melhor preço no mercado, diminuindo assim a soma a ser paga ao fornecedor. Em função desse modelo, muitas vezes não se compatibiliza com as decisões de produção, sobretudo em momento de safra, que motiva os produtores a reajustarem seus preços no fornecimento de etanol para os distribuidores. Essa complexidade pode se agravar em situações em que usineiros fecham acordo contratual com empresas do setor energético de eletricidade, devendo este cumprir com suas cotas de fornecimento, decorrente da cogeração de energia, como subproduto da produção do etanol hidratado.

Portanto, a falta de coordenação entre os produtores de açúcar e etanol e a categoria dos fornecedores de cana constituem a dinâmica, complexa, na oferta de etanol hidratado no mercado interno, cabendo a necessidade de coordenação estratégica entre usineiros, fornecedores de cana, governo e população, à medida que as perspectivas positivas quanto ao futuro do setor forem se consagrando, como é o caso do flex, que impulsionou a demanda, e certamente com a possibilidade de outros usos (eteno e farneceno). Similarmente, constata-se que o setor sucroenergético empreende atitudes oportunistas ao alcance de um mecanismo de autogestão efetivo, sem flutuações intensas e abruptas nos níveis de produção de cana, açúcar e etanol (MELLO, 2004, p. 17).

Entretanto, o dinamismo da oferta permeia sobre os conflitos de interesses que ainda são verificados no setor por conta de questões produtivas, devido à falta de maturidade organizacional, herdada da desregulamentação do setor, permitindo que muitos agentes deixem de buscar um planejamento conjunto da oferta de matéria-prima, o que pode acabar refletindo em superoferta de açúcar ou de etanol e, consequentemente, em oscilações 
frequentes nos preços, uma vez que a demanda se apresenta em crescimento. Além da desregulamentação no setor, há também o dinamismo na própria heterogeneidade produtiva ${ }^{9}$ entre as regiões Centro-Sul e Norte-Nordeste e, futuramente, agravada pelas opções entre usos alternativos em produzir eteno e farneceno.

Portanto, a falta de uma coordenação capaz de equilibrar-se adequadamente aos dinamismos do setor produtivo, com a ausência de um processo de construção coletiva de um sistema de planejamento de produção que unifica os parâmetros estratégicos de todos os agentes do setor sucroenergético sob sua heterogeneidade produtiva, tem cooperado, principalmente em épocas de entressafra, para o péssimo quadro da baixa oferta de etanol no mercado de combustíveis do Brasil. É oportuno enfatizar que, a percepção das oscilações de preços no mercado interno que além de resultar da elevação da demanda, é também motivada por agentes ofertantes (ilegais e clandestinos) de etanol hidratado aos quais agem, muitas vezes, em postos de revenda não bandeirados alterando a composição final do produto, como é o caso do "etanol molhado" (realiza-se enorme aquisição por etanol anidro e posteriormente adiciona-se a certa quantidade de água para alcançar o etanol hidratado, evitando-se o pagamento por tributos que oneram especificamente o etanol hidratado, sobretudo antes de 2006 onde o corante passou a ser obrigatório no fornecimento pelos produtores). Dado o dinamismo de seus mercados responsáveis pelas oscilações nos preços do etanol hidratado, cabe ressaltar, que o setor sucroenergético não assegura em seus níveis de complexidade a estimativa de uma oferta coordenada às necessidades de seus agentes em toda a cadeia produtiva.

Com relação à demanda por etanol hidratado produzido no Brasil, esta se encontra atualmente em ascendência, decorrente do flex, demanda externa por açúcar e usos alternativos na indústria alcoolquímica, bem como às prospecções ditadas pelo eteno e farneceno. Tal dinamismo não conseguirá sozinho atender toda a prospecção da demanda se, ainda motivada pelo mercado internacional, tiver de atender às suas regulações ambientais, fazendo-se necessária a constituição do desenvolvimento da produção doméstica a ser adotada por vários países, sem que os quais recorrem às importações no curto prazo, o que certamente comprometeria a oferta interna, impactando, por sua vez, na elevação dos preços. Desse modo, para garantir o abastecimento do etanol no mercado interno em patamares que não

\footnotetext{
${ }^{9}$ A heterogeneidade produtiva corresponde à dispersão geográfica, tecnologia, aprendizagem organizacional, proximidade dos fornecedores, muda condizente ao clima e solo, acessibilidade a recursos financeiros e à própria concorrência entre os industriais.
} 
forcem as oscilações nos preços, o setor sucroenergético deve adotar mecanismos de coordenação, como a criação de estoques estratégicos ou de segurança.

Os proprietários de veículos flexíveis têm a opção de escolher o etanol como principal combustível, sob sua relação econômica com a gasolina, exaurindo-o da situação de dependência do produto. Entretanto, o consumidor precisa ter confiança no pleno abastecimento, além do acesso a preços competitivos para o produto, para que não ocorra outra crise como a do final dos anos 1980, quando o Proálcool caiu totalmente em descrédito diante da queda nos preços do petróleo e aumento na produção de açúcar, em detrimento da produção de etanol. Assim, numa expansão no mercado mundial de etanol, por forças regulatórias de preservação do meio ambiente efetivar-se, o impacto tende a estar relacionado com a expansão de sua demanda, independentemente dos preços do combustível substituto, gasolina.

De acordo com as constatações apresentadas por Scandiffio (2005, p. 97), notou-se que o consumo de etanol está relacionado com o tamanho da frota (em maior intensidade) e com o preço do combustível (em menor intensidade), e esta poder-se-á ser observada neste estudo, uma vez que tal relação foi investigada quantitativamente na análise de regressão linear múltipla, uma vez que os carros flex fuel rodam tanto com gasolina $\mathrm{C}$ como com etanol hidratado. Porém, presume-se, preliminarmente, que o aumento do consumo de etanol dependerá tanto do tamanho da frota de veículos flex fuel e dos carros movidos somente a etanol, como da relação dos preços entre os dois combustíveis: etanol e gasolina. Como os automóveis flexíveis têm sido os responsáveis pela propulsão da demanda de etanol no país, e tal dinamismo, se ora não acompanhado da oferta, torna sua competitividade nula em relação à gasolina $\mathrm{C}$, pois os preços tendem a se elevar.

A elevada carga tributária também proporciona o dinamismo dos preços, flexionando a uma redução da demanda. Isso ocorre porque, atualmente, os Estados brasileiros têm uma carga tributária diferente, o que torna o etanol competitivo em relação à gasolina $\mathrm{C}$ dentre os Estados brasileiros. Se existisse uma carga tributária uniforme em todo o país, mais de $80 \%$ dos proprietários de carros flex e, exclusivamente a etanol, abasteceriam seus veículos com etanol hidratado, conforme estimativas da UNICA. Contudo, a homogeneidade tributária 
dentre os Estados do país implica em interesses fiscais associados à sua respectiva frota de veículos.

Se as perspectivas de crescimento da demanda interna de etanol forem efetivadas, 55 bilhões de litros até 2020, acompanhadas aproximadamente da mesma quantidade a ser ofertada, e desconsiderando o potencial mercado exterior, que conforme também constatado nesse estudo está estimado em 39 bilhões de litros; sem ainda estimar a possibilidade do cenário se agravar ainda mais em termos de escassez pela possibilidade do farneceno se consagrar viável em seu uso, possivelmente os preços tendem a se manter inconstantes. Desse modo, o desafio que se coloca a todos os agentes do setor sucroenergético é analisar alternativas que visem suprir tais necessidades, visando maior coordenação entre o setor sem que interfira ao descrédito do consumidor final em sua autonomia de decisão por preços competitivos.

\subsection{Distribuição e Coleta: Logística}

No setor de coleta e distribuição de combustíveis, a principal modificação foi o fim da chamada estrutura de preços. Em conformidade com Xavier (2008, p. 40), havia uma estrutura de preços, durante a fase do Proálcool, em que o governo podia estabelecer um preço uniforme para os combustíveis em todos os postos do Brasil, independentemente de sua distância da base de distribuição supridora ou da complexidade da cadeia de suprimentos desde a região produtora. $\mathrm{O}$ autor ainda destaca que a estrutura de preços baseava-se no sistema de ressarcimento de fretes, pagos pela empresa estatal Petrobras, e funcionava como um fundo de compensação em que todos os fretes eram ressarcidos às distribuidoras pelo governo, que, por sua vez, recolhia uma alíquota incidente no preço dos combustíveis para compor a receita deste fundo. Esse fato garantia que os preços do etanol hidratado nos postos de revenda fossem mais atrativos para o consumidor final, sendo essa a pretensão do governo em ter de fomentar incentivos para que o Proálcool pudesse ser consolidado no mercado de combustíveis.

Segundo Maligo (2005, p. 41), a estrutura de preços trazia embutida a necessidade de fixar rotas e modais de transporte, para que o governo controlasse os ressarcimentos dos fretes. Esse era o mecanismo com que o Departamento Nacional de Combustíveis (DNC), extinto com a criação da ANP, fixava e controlava o processo de distribuição junto aos municípios de 
origem e destino autorizados. Nesse contexto, Xavier (2008, p. 40) reforça que, com a consolidação das bases de distribuição de combustíveis localizadas em município autorizado e com a delimitação de distribuidoras, tem-se o direito ao ressarcimento dos fretes correspondentes à sua movimentação; logo, essa concentração nesse tipo de canal de distribuição implicou no sucateamento e na variação nos preços do combustível etanol atualmente. Ou seja, a existência da estrutura de preços regulamentada pelo governo por meio do DNC desestimulou o desenvolvimento da logística nas distribuidoras, distorcendo o preço final dos produtos. Esse mecanismo não permitia que o setor de transporte se desenvolvesse, dado que a alíquota era maior em regiões próximas dos produtores, e menor nas regiões mais distantes, comportando-se de forma inversa ao custo do frete, obtendo-se, portanto, um custo final uniforme em todo o território nacional. Assim sendo, o consumo das regiões mais próximas aos produtores subsidiava o consumo das regiões distantes. $\mathrm{O}$ ressarcimento dado às distribuidoras era feito pelo governo, o que ocasionou, portanto, um sucateamento na distribuição dos combustíveis e uma falsa percepção de que os preços do combustível etanol eram similares em todas as regiões do país.

Desse modo, nota-se que os custos de fretes, os custos com armazenagem e estoques, que envolviam a logística como um todo, estavam obsoletos ao novo cenário que o mercado do etanol desenhou nesse início do século XXI, dado que o governo subsidiava as distribuidoras por essas respectivas despesas, e que após a saída intervencionistas, os preços nas distribuidoras e nos postos de revenda passaram a ser reajustados por conta desse componente custo que antes era subsidiado pela Petrobras.

Em conformidade, Araújo (2006, p. 46) acrescenta que a atividade de logística nas distribuidoras (e usinas) ganhou importância após os custos logísticos deixarem de ser ressarcidos pelo governo e passarem a fazer parte da formação de preços dos combustíveis; logo, a eficiência logística passou a ser um diferencial na competitividade entre as distribuidoras de combustíveis e as usinas, implicando na diferenciação dos preços no posto de revenda.

Atualmente, os sistemas de comercialização de etanol adotados pelas usinas, após a desregulamentação, conta com uma estrutura logística ainda existente da fase do Proálcool. Ou seja, há tecnologia no setor da indústria automobilística, com o motor flex, e 
sucroenergética, com ganhos de produtividade, mas não houve desenvolvimento estrutural quanto à distribuição dos combustíveis no mercado interno, e esse fato interfere na precificação do produto.

Essa percepção pelo consumidor final da diferenciação nos preços compreendida pelo fim da fase intervencionista, em que subsídios logísticos não mais vigoram para as distribuidoras, foi característica do fim da década de 1990, porém suficiente para cooperar com a percepção de que preços de etanol são voláteis no mercado nacional. E tal fato foi agravado com a existência de postos de revenda de "bandeira branca", que recepcionavam o etanol hidratado de distribuidoras que se abasteciam de usinas que precisavam se capitalizar. Daí deduz-se a existência de uma das diferenças de preços ao consumidor final que perdura até hoje no mercado brasileiro.

Entende-se que, com a desregulamentação do setor, acentuaram-se as oscilações de preços de etanol hidratado por dois momentos: o primeiro era decorrente à falta de estoque para praticar liberação do produto no mercado como forma de segurar o aumento de preços e, no segundo, pela falta de formação de estoque para evitar quedas acentuadas de preços que levassem a prejudicar a atividade produtiva. Essa constatação da causa real revela o momento em que há conflito de interesses e imediatismos que interferem na compreensão da dinâmica dos fenômenos econômico-sociais, dando ao consumidor final uma percepção duvidosa sobre o comportamento dos preços do etanol, e esse fato dava-se no mesmo instante em que as empresas sistemistas investiam no desenvolvimento do flex.

O setor sucroenergético atualmente, segundo Neves e Canejero (2007), depara-se com essa problemática de decisões, relativas à distribuição e à logística, tomadas pelas usinas no mercado interno de etanol. Algumas estratégias são propostas para assegurarem boas condições para esse mercado, inclusive no que compete à formação de preços, tais como:

a) usinas que estejam numa mesma região podem montar joint ventures e entrar no mercado de distribuição de etanol, com uma gestão independente, comprando distribuidoras hoje existentes ou montando novas, autorizadas a funcionar pelo governo;

b) as usinas, em formas organizacionais associativas, que podem ser franquias ou joint ventures, podem montar postos de combustíveis nas cidades. Esses postos não viriam para competir com as redes existentes (seriam poucos), mas seriam postos "conceito" (o nome da rede poderia ser verde ou green), e serviriam para duas funções básicas: estabelecer os preços varejistas do etanol (dificultando a ação de cartéis urbanos) e comunicar a imagem ao consumidor final;

c) melhoria da infraestrutura de escoamento da produção de etanol - é necessário dar velocidade aos investimentos já anunciados por meio de dultos, bem como às estruturas portuárias para exportação de etanol; 
d) agilização das parcerias público-privadas (PPPs), que fortaleçam um amplo programa de privatização de rodovias, e outros aspectos de infraestrutura, visando não onerar o etanol que vem de regiões mais distantes e que hoje sofre com os problemas de custos de transporte no Brasil. (NEVES; CONEJERO, 2007, p. 32).

Diante dessas contribuições, é necessário destacar o aspecto da infraestrutura logística na distribuição de combustíveis no Brasil, o qual vem se revelando como o limitador competitivo dentre as distribuidoras. Uma vez que a demanda por combustíveis aumentou em razão de uma série de fatores, como: o próprio aumento da frota de veículos no país, pelo crescimento da economia brasileira e o surgimento das indústrias e do comércio em geral; e, ademais, produtores vêm alcançando níveis de produtividade em paralelo com as indústrias sistemistas ligadas ao setor automobilístico, resta então à base estrutural distributiva cumprir com seu papel de minimizar custos relacionados à logística, sobretudo àquelas herdadas da fase do Proálcool.

Cabe destacar que a dinâmica dos preços do etanol hidratado tem sua identificação também constituída da localização das unidades produtoras de etanol no país, que, no ano de 2010, conforme dados do Ministério da Agricultura, Pecuária e Abastecimento, o setor sucroenergético contou com 437 unidades produtoras, sendo 168 produtoras de etanol, 16 de açúcar e 253 de açúcar e etanol (SINDICOM, 2010). Na Figura 8 é possível notar a distribuição espacial das unidades produtoras de etanol no país em operação (pontos pretos) e em construção (pontos verdes).

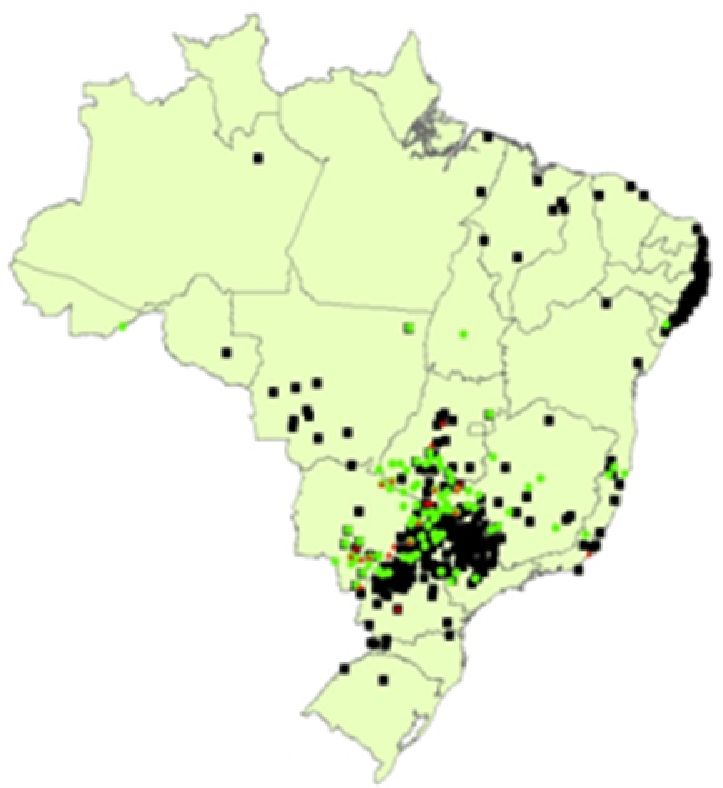

igura 8 - Localização das unidades produtoras de etanol Fonte: Sindicom (2010). 
De acordo com a Sindicom, a concentração de unidades produtoras de etanol encontra-se na região Centro-Sul, principalmente no Estado de São Paulo, responsável por aproximadamente $89 \%$ da produção brasileira.

No que compete às usinas ou destilarias produtoras de etanol, pode-se afirmar que seu ponto de maturação técnica e administrativa na cadeia produtiva sucroenergética está bem estruturado, mesmo em situações relacionadas à cultura, pois é um setor que apresenta rotatividade a cada cinco anos. A terra, após cinco anos na exploração do cultivo da cana, é repousada com outro tipo de cultivo alimentício, como o amendoim. Esse fato desencadeia em produtividade, ganhos de escala, redução de custos e o fato também de estarem próximas aos principais centros distribuidores, refinarias e da principal região em número de frotas de veículos leves de motor flex e somente a etanol. Trata-se de uma região onde as oscilações de preços ocorrem e, pelo fato da existência do maior número de unidades de produtores e distribuidores, passa a ser uma região que sensibiliza os preços para as demais do país.

A rede distributiva do etanol no país tem sua regulamentação por meio do art. $8^{\circ}$ da portaria $n^{\circ}$ 116, de 5 de julho de 2000 da ANP, que arbitra o exercício da atividade de revenda varejista de combustível automotivo, determinando que exclusivamente as distribuidoras de combustíveis possam suprir os postos de revenda. Ou seja, essa legislação não permite o fluxo direto de distribuição de etanol combustível entre usinas e clientes finais, postos de combustíveis, no mercado interno, sem que haja a interseção da distribuidora. A Figura 8 demonstra a concentração de distribuidores na região Centro-Sul, portanto, próximo aos produtores de etanol, perfazendo um eixo estratégico de localização para atender às bases distribuidoras por oferecer baixos custos com relação a transportes entre produtores distribuidores - postos de revenda. As distribuidoras exercem um papel fundamental na cadeia de suprimentos de combustíveis etanol, pois atuam na captação, armazenamento, transporte e comercialização. Exercem, ainda, o controle de qualidade, devendo garantir que o mercado seja adequada e economicamente suprido. Essa etapa, tida como final na cadeia produtiva do etanol, atua com economias de escalas na consolidação de cargas nas bases de distribuição, devendo estar localizadas em pontos logísticos estratégicos tanto pelo uso da modalidade adequada de transporte quanto pela eficiência na operação logística, de tal modo que os custos não onerem ainda mais os preços na revenda. 
Já em relação ao canal de distribuição, este tem sua forma apropriada para a operacionalização do comércio de combustíveis e seus derivados por meio da triangulação: distribuidora - posto revendedor - destinatário final. E a relação entre as distribuidoras e os revendedores ocorre por meio de um contrato, otimizando os custos de transação. É quando também surge um vínculo entre distribuidora e posto revendedor, pelo qual aquela abastece os tanques deste, conforme condições de galonagem, preços e prazos, gerando lucros para ambas as partes. Vale enfatizar que, atualmente, os canais de distribuição de combustíveis nos postos revendedores não estão mais obrigados a se vincularem a uma única distribuidora.

Há que se considerar também que os postos revendedores de combustíveis exercem atividade de revenda em seus estabelecimentos comerciais, e são responsáveis não só pela comercialização dos combustíveis, como também pelos derivados de petróleo aos veículos automotivos. Se o posto de combustível firmar contrato de exclusividade a uma determinada marca de uma distribuidora, surgirá a obrigação de cumprir determinadas cláusulas contratuais que, normalmente, são impostas pela rede distribuidora, não somente em razão de cláusula contratual, mas também em respeito à regulação auferida pela agência reguladora, a ANP, as quais devem agir em consonância com o Código de Defesa do Consumidor, compreendidos, portanto, como postos bandeirados.

De acordo com o Sindicom (2010), o contrato de exclusividade consiste na vinculação do revendedor varejista à distribuidora, da qual decorre a obrigação do primeiro em comercializar em seu posto revendedor unicamente produtos fornecidos pela segunda, garantindo, assim, à distribuidora um escoamento de seus produtos. Por sua vez, a distribuidora não só garante o abastecimento à revenda, como também concede outras vantagens como a licença do uso da marca, insígnia e cores, sobre os quais incidem toda a propaganda e publicidade da distribuidora, além do fornecimento em comodato dos equipamentos necessários ao funcionamento do posto.

No Brasil, grandes distribuidoras de combustíveis, como Esso, Shell e Texaco, Atlantic, Ipiranga e Petrobras, sempre detiveram o oligopólio da distribuição, razão pela qual são conhecidas como as "seis irmãs" devido à política de boa vizinhança, auferindo lucros exorbitantes, face ao manifesto domínio exercido sobre o mercado, em detrimento dos consumidores, e essa prática é notória desde a segunda década do século $\mathrm{XX}$, visto que elas 
majoravam forte influência no mercado de combustível no início da década passada, uma vez que o antigo Conselho Nacional do Petróleo dava a essas distribuidoras, e somente a elas, o poder de requerer àquele órgão a autorização para instalação de postos revendedores, isto é: quem quisesse abrir um posto de gasolina necessariamente deveria revender produtos de uma destas distribuidoras, estabelecendo o domínio por parte delas na determinação dos preços ao consumidor final.

Ainda no mercado de distribuição de combustíveis, deve-se considerar também a existência do posto "bandeira branca", o qual, devidamente regulamentado pela ANP, permite maior competitividade por não oferecer ao posto de revenda contrato de exclusividade e das imposições de uma empresa distribuidora bandeirado. Dessa maneira, a contratação de exclusividade às redes não impede a entrada de novas revendas no mercado, pois a existência de postos "bandeira branca" possibilita o acesso de novos distribuidores à atividade. E há também a possibilidade de que mesmo os postos que estão vinculados a uma distribuidora, ao findo do seu contrato, poderem optar por nova negociação, ou então realizar a troca de bandeira. Entretanto, a existência da distribuidora e da revenda não bandeirada permite competitividade de preços de etanol hidratado, porém, coloca o consumidor final em dúvida quanto à qualidade oferecida no produto. Isso porque as fraudes são mais notáveis entre postos não bandeirados, já que estes não necessitam de rigores contratuais estabelecidos entre distribuidoras e revendedoras.

Cabe destacar que o principal dinamismo dos preços do etanol hidratado no mercado de combustíveis parte da relação comercial que grandes distribuidoras no país possuem com os postos de revenda, cujos preços são previamente acordados com prazo de, no mínimo, 10 dias de carência, compreendidos entre a data do recebimento do combustível e o respectivo vencimento da fatura, cabendo, em algumas situações acordadas, dissonância na negociação entre esses agentes (distribuidora e revenda); e é nesse contexto que a distribuidora começa a exigir preços diferenciados na revenda, condicionando a venda de seus produtos ao posto apenas mediante pagamento antecipado, sob pena de cancelamento do abastecimento e ameaça de remoção dos equipamentos essenciais cedidos em regime de comodato. Esse fato promoveu o crescimento dos postos chamados "bandeira branca", que se desvincularam das grandes distribuidoras. No entanto, cabe o esforço em ter de levar ao consumidor final o valor percebido de qualidade e segurança do combustível, sendo este o desafio, já que o consumidor 
tem associado o baixo preço pago na bomba à baixa qualidade.

Dentre o contexto da liberalização dos preços dos combustíveis, a não obrigatoriedade da revenda se vincular a uma distribuidora e às fortes imposições das grandes distribuidoras no país promoveu a operacionalização entre revenda "bandeira branca" e pequenas distribuidoras, com preços inferiores aos das grandes companhias. Cabe salientar que há muitos revendedores de combustíveis atrelados por contratos leoninos às grandes distribuidoras, rompendo seus acordos e migrando para a revenda "bandeira branca", alegando abuso do poder econômico imposto pela distribuidora e o fato de resguardar a livre concorrência.

Outro aspecto importante a ressaltar é quanto à metodologia de cálculo dos preços do combustível etanol hidratado realizado pela ANP, que é realizado sob uma amostragem de postos de combustíveis espalhados por várias regiões do país. Ocorre que o cálculo da média se mistura entre postos bandeirados e não, cabendo aqui o destaque de discussões futuras no que diz respeito à possibilidade de avaliar os preços de modo individual entre esses dois grandes grupos.

Dessa forma, pode-se concluir que atualmente no país há dois modelos de operacionalização comercial entre revenda e distribuidora: os postos de abastecimento de combustíveis, o tradicional, que, atrelado a um contrato de revenda com uma distribuidora, adquire produtos exclusivamente desta, e o de "bandeira branca", que, por não estar vinculado a uma distribuidora em especial, adquire combustíveis de qualquer delas, por intermédio de contratos de compra e venda mercantil, possuindo o dever de informar ao consumidor, em cada bomba de abastecimento, a distribuidora que fornece o referido combustível e suas respectivas especificações técnicas quanto ao controle de qualidade, sendo estes com preços mais competitivos.

E, com preços mais competitivos, a alegação observada dentre as grandes distribuidoras, por meio do Sindicom, é que a desregulamentação do setor promoveu uma forte distorção na concorrência, afetando diretamente o consumidor final. Tal fato vem desencadeando a atuação de distribuidoras não qualificadas, postos vendendo combustível adulterado (além de não se saber a origem do produto), sonegação de impostos, usinas/destilarias fornecendo direto aos 
postos sem passar por essas distribuidoras, além do fato de empresas beneficiadas com liminares poderem oferecer preços muito inferiores aos praticados no mercado, causando ao consumidor várias percepções, como: preços sendo manipulados pelas grandes revendas e de adulteração de combustível em postos "bandeira branca". Outra constatação junto ao órgão é de uma possível formação de cartel por parte das pequenas distribuidoras, que venderiam combustíveis a um preço muito abaixo do praticado pelos postos afiliados às grandes distribuidoras, distorcendo e agravando ainda mais a percepção dos preços de etanol ao consumidor final de combustível.

As distribuidoras do Sindicato Nacional das Distribuidoras de Combustíveis e Lubrificantes Sindicom são as maiores, com marcas mais conhecidas, e possuem redes de postos com suas bandeiras e com maior participação no mercado de distribuição de combustíveis. O Sindicom atua com as distribuidoras, consagrando uma associação em que estão presentes: AirBP, Ale, Castrol, Chevron (Texaco no Brasil), Esso, Ipiranga, BR Distribuidora, Petronas Lubrificantes, Repsol e Shell, entre outras. Vale frisar que hoje existem distribuidoras emergentes, como a Ale, que também fazem parte do Sindicom, e para o mercado de etanol toda essa associação representa uma participação equivalente a $60 \%$ de market share.

Observa-se, portanto, que o mercado de combustíveis no país atualmente se subdivide em dois grandes grupos: distribuidoras emergentes e aquelas ligadas ao Sindicom. As distribuidoras emergentes, que surgiram no mercado após a desregulamentação do setor, são companhias com menor participação no mercado, com marcas menos conhecidas, menor volume de venda, que nem sempre possuem rede de postos e geralmente trabalham apenas com a distribuição de etanol, atuando mais regionalmente - "bandeiras brancas".

Cabe destacar que no varejo de combustíveis há um mercado concentrado nas mãos de poucas distribuidoras. No Gráfico 3, é possível perceber a participação das distribuidoras pelos combustíveis gasolina $\mathrm{C}$ e etanol hidratado. 


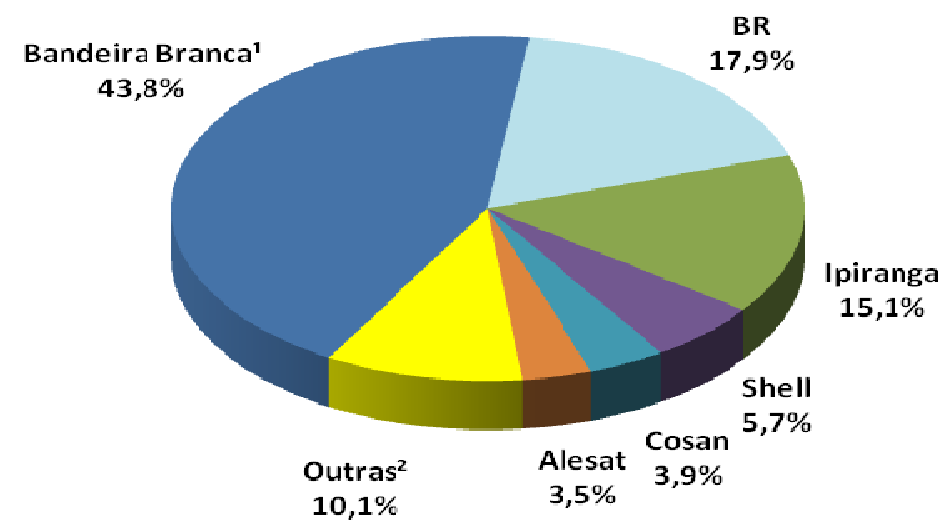

1113 bandeiras

Gráfico 3 - Distribuição percentual dos postos revendedores de combustíveis automotivos no Brasil, segundo a bandeira, em 31/12/2009

Fonte: ANP (2010).

O gráfico reforça o quanto são expressivos os postos de revenda "bandeira branca" no país, perfazendo $43,8 \%$ de participação no mercado, do montante dos 36.730 mil postos existentes. Há que se considerar que, do total de 508 distribuidoras presentes no país, boa parte do mercado de distribuição de etanol carburante está concentrada nas mãos de um número reduzido de empresas, com apenas cinco delas detendo quase 50\% (BR, Ipiranga, Shell, Cosan e Alesat), ao passo que 113 constituem o montante dos postos "bandeira branca".

Para Lopes (2009, p. 97), a concentração das companhias distribuidoras no mercado de combustíveis, somada ao elevado número de usinas produtoras de etanol, influencia diretamente o processo de distribuição do produto, conferindo maior poder de barganha às distribuidoras nas negociações com as usinas e, por conseguinte contribuindo para as distorções de preços dentre as diversas regiões do país.

Assim, o alto poder que as distribuidoras possuem faz que elas consigam influenciar não só o comportamento dos produtores (usinas), como também dos revendedores (postos), minimizando potenciais custos de transação e priorizando modelos contratuais ou acordos relacionais ao invés de integração vertical, que pode ser extremamente custosa para a empresa. Esse efeito leva a fusões, como foi a aquisição do grupo Cosan pela rede distribuidora de combustíveis Esso, cujo objetivo era conquistar poder de negociação na comercialização de combustíveis, usufruindo-se de um sistema de integração vertical da produção e distribuição de etanol, o que lhes confere menor custo de transação, ou seja, reduzir as incertezas e proteger seus investimentos em ativos específicos para a produção do 
combustível, o que não implica que o combustível chegará ao posto de revenda mais barato. Essa medida não tem efeito competitivo do combustível no posto de revenda, mas sim procura otimizar a logística e melhorar a gestão de estoque, além de aumentar a proximidade com o consumidor final.

No segmento de distribuição, a flexibilização dos requisitos de entrada, a partir de 1993, provocou um aumento significativo de distribuidoras, de acordo com os dados da ANP, que registrou em 1990 apenas 10 distribuidoras, e, em 1993, o país já contava com cerca de 400 distribuidoras atuantes, reduzindo o número para 322 em 2001, uma queda significativa dada a atuação na fiscalização pela ANP. Atualmente, conta com cerca de 508 distribuidoras e 470 Transportadores Revendedores Retalhistas, para que sejam atendidos 36.730 postos de combustíveis no país. A Figura 9 a seguir revela, respectivamente, como os postos estão distribuídos dentre as unidades da Federação, em seguida, a distribuição da frota de veículos dentre os principais Estados representativos do país.

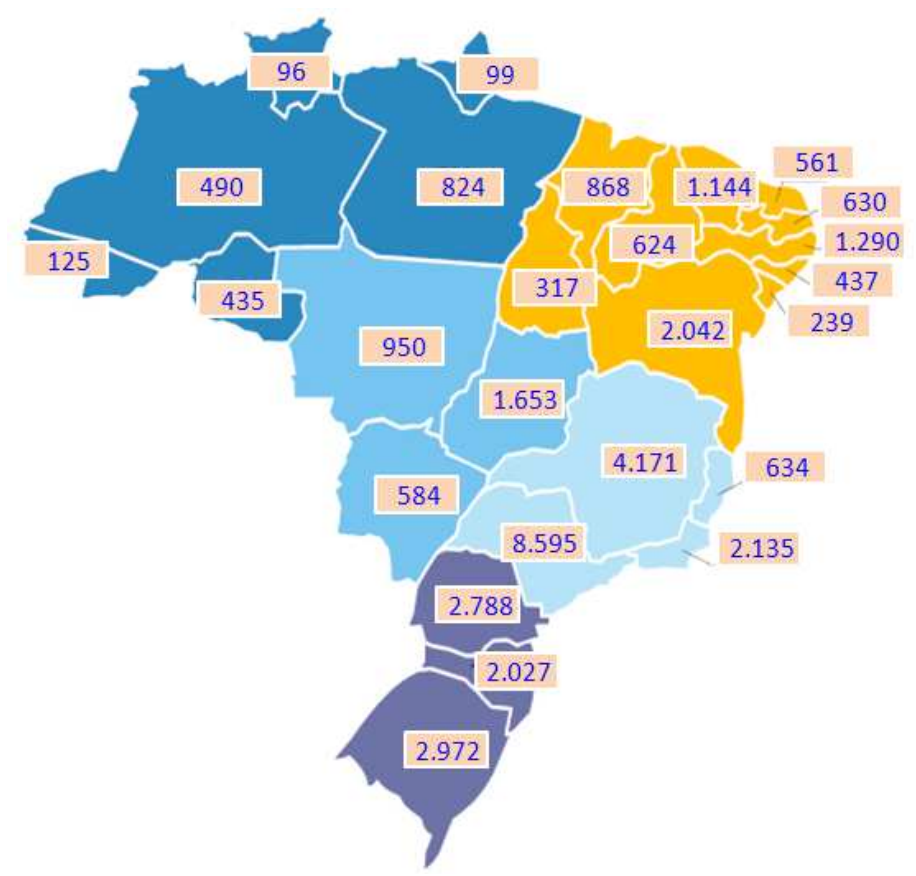

Figura 9 - Quantidade de postos revendedores de combustíveis por Unidade de Federação (2009) Fonte: ANP (2010) - adaptado pelo autor. 


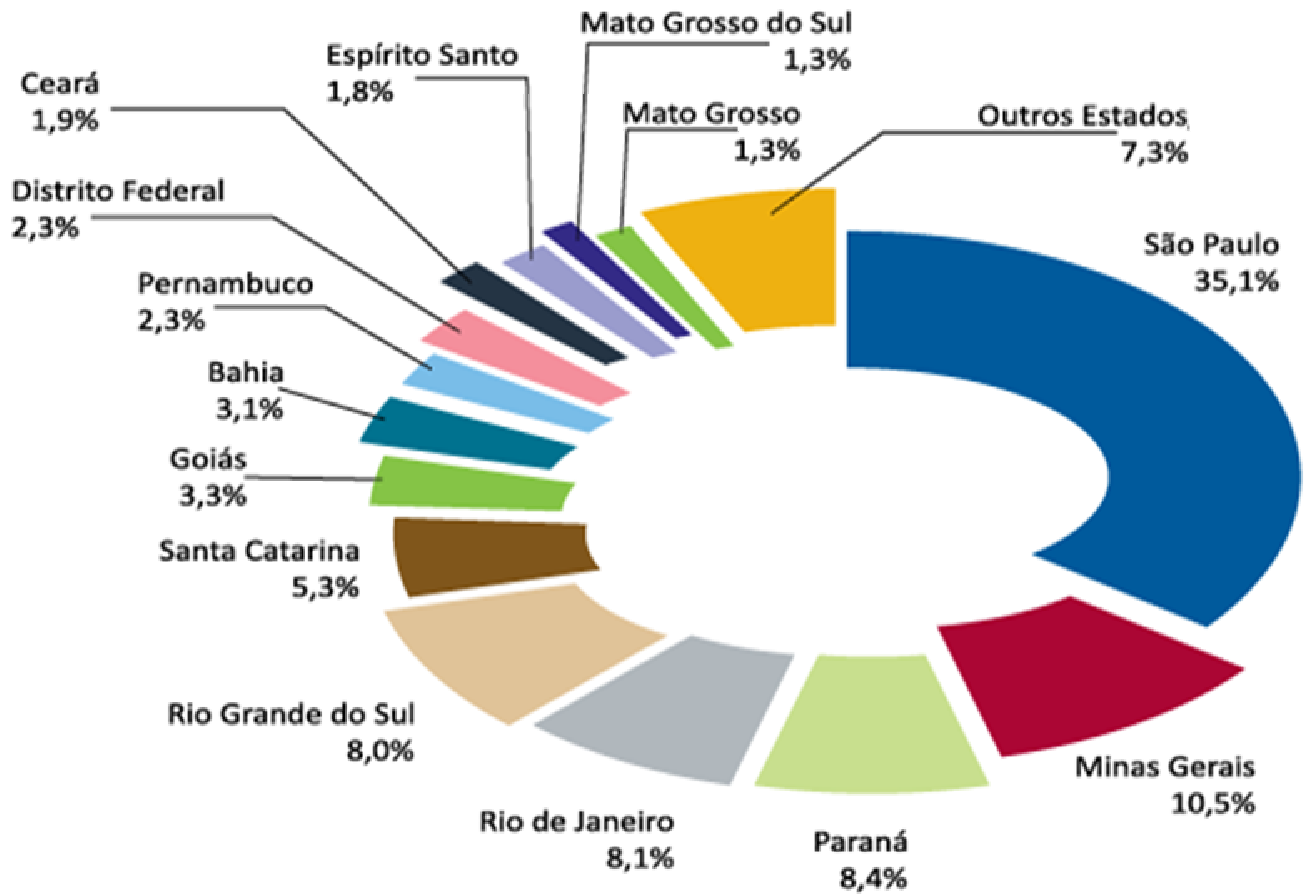

Gráfico 4 - Frota de autoveículos distribuídos em porcentagem por Unidade da Federação (2009) Total de autoveículos: 29.643 (mil unidades) Fonte: Anfavea (2010b).

A Figura 9 e o Gráfico 4 permitem correlacionar a quantidade de postos existentes no Estado com a frota de veículos. É possível notar que, no Estado de São Paulo, dos 8.595 postos de revenda de combustíveis, há uma frota equivalente 10.404 .693 veículos, ou seja, para cada posto existem cerca de 1.210 veículos. Já no Estado do Mato Grosso do Sul, a proporção é cerca de 660 veículos por posto de revenda de combustível. E, considerando a hipótese de haver um imposto único (ICMS) a ser cobrado entre todas as Unidades da Federação, fica evidente, nesse caso, que o Mato Grosso do Sul não se beneficiaria na arrecadação em relação ao Estado de São Paulo, por possuir uma frota bem inferior, o que traria para o MS complicações orçamentárias para o Estado quanto à arrecadação de ICMS proveniente de combustíveis.

Já a Tabela 9 permite observar que, dos 36.730 postos de revenda de combustíveis existentes no país, 15.917 (57\%) são postos de "bandeira branca", espalhados nas mais diversas regiões, sendo os Estados de São Paulo, Minas Gerais e Paraná os mais significativos. 
Tabela 9 - Quantidade de postos revendedores de combustíveis automotivos por bandeira (2009)

\begin{tabular}{|c|c|c|c|c|c|c|c|c|c|}
\hline $\begin{array}{c}\text { Regiões e } \\
\text { U.F. }\end{array}$ & Total & BR & Ipiranga1 & Chevron & Shell & Esso & Alesat & $\begin{array}{c}\text { Bandeira } \\
\text { Branca2 } \\
\end{array}$ & Outras3 \\
\hline Brasil & 36.730 & 6.252 & 3.922 & 2.103 & 2.106 & 1.470 & 1.058 & 15.917 & 4.082 \\
\hline Região Norte & 2.386 & 403 & 105 & 157 & 17 & 14 & 35 & 1.196 & 459 \\
\hline Rondônia & 435 & 41 & 40 & 15 & 6 & 1 & - & 239 & 93 \\
\hline Acre & 125 & 46 & 4 & 1 & - & - & - & 55 & 19 \\
\hline Amazonas & 490 & 79 & 2 & 14 & 4 & - & - & 181 & 210 \\
\hline Roraima & 96 & 39 & - & - & 1 & - & - & 38 & 18 \\
\hline Pará & 824 & 128 & 29 & 83 & 4 & 12 & 20 & 440 & 108 \\
\hline Amapá & 99 & 24 & - & 32 & 1 & - & - & 42 & - \\
\hline Tocantins & 317 & 46 & 30 & 12 & 1 & 1 & 15 & 201 & 11 \\
\hline $\begin{array}{l}\text { Região } \\
\text { Nordeste }\end{array}$ & 7.835 & 1.386 & 316 & 359 & 288 & 193 & 394 & 3.776 & 1.123 \\
\hline Maranhão & 868 & 98 & 17 & 34 & 2 & 17 & 56 & 565 & 79 \\
\hline Piauí & 624 & 115 & - & 26 & 2 & 14 & 12 & 422 & 33 \\
\hline Ceará & 1.144 & 267 & 30 & 66 & 41 & 32 & 50 & 450 & 208 \\
\hline $\begin{array}{l}\text { Rio Grande } \\
\text { do Norte }\end{array}$ & 561 & 104 & 32 & 12 & 18 & 10 & 105 & 230 & 50 \\
\hline Paraíba & 630 & 65 & 13 & 47 & 17 & 6 & 26 & 332 & 124 \\
\hline Pernambuco & 1.290 & 212 & 66 & 84 & 72 & 33 & 49 & 532 & 242 \\
\hline Alagoas & 437 & 127 & 33 & 30 & 16 & 9 & 11 & 192 & 19 \\
\hline Sergipe & 239 & 62 & 22 & 4 & 14 & 12 & 7 & 61 & 57 \\
\hline Bahia & 2.042 & 336 & 103 & 56 & 106 & 60 & 78 & 992 & 311 \\
\hline $\begin{array}{l}\text { Região } \\
\text { Sudeste }\end{array}$ & 15.535 & 2.685 & 1.519 & 781 & 1.272 & 833 & 540 & 7.090 & 815 \\
\hline Minas Gerais & 4.171 & 894 & 367 & 188 & 198 & 145 & 232 & 1.890 & 257 \\
\hline Espírito Santo & 634 & 115 & 58 & 61 & 41 & 56 & 67 & 209 & 27 \\
\hline Rio de Janeiro & 2.135 & 382 & 234 & 118 & 207 & 150 & 84 & 891 & 69 \\
\hline São Paulo & 8.595 & 1.294 & 860 & 414 & 826 & 482 & 157 & 4.100 & 462 \\
\hline Região Sul & 7.787 & 1.275 & 1.640 & 556 & 353 & 384 & 21 & 2.202 & 1.356 \\
\hline Paraná & 2.788 & 356 & 432 & 165 & 152 & 161 & 16 & 1.216 & 290 \\
\hline $\begin{array}{l}\text { Santa } \\
\text { Catarina }\end{array}$ & 2.027 & 293 & 332 & 224 & 65 & 99 & 5 & 492 & 517 \\
\hline $\begin{array}{l}\text { Rio Grande } \\
\text { do Sul }\end{array}$ & 2.972 & 626 & 876 & 167 & 136 & 124 & - & 494 & 549 \\
\hline $\begin{array}{l}\text { Região } \\
\text { Centro-Oeste }\end{array}$ & 3.187 & 503 & 342 & 160 & 86 & 46 & 68 & 1.653 & 329 \\
\hline $\begin{array}{l}\text { Mato Grosso } \\
\text { do Sul }\end{array}$ & 584 & 153 & 106 & 26 & 3 & 8 & - & 164 & 124 \\
\hline Mato Grosso & 950 & 109 & 84 & 13 & 3 & - & 6 & 598 & 137 \\
\hline Goiás & 1.339 & 124 & 121 & 86 & 41 & 18 & 58 & 824 & 67 \\
\hline $\begin{array}{l}\text { Distrito } \\
\text { Federal }\end{array}$ & 314 & 117 & 31 & 35 & 39 & 20 & 4 & 67 & 1 \\
\hline
\end{tabular}

1 inclui as bandeiras CBPI e DPPI. 2 posto que pode ser abastecido por qualquer distribuidora. 3 inclui outras 109 bandeiras.

Fonte: ANP (2010).

De acordo com a Tabela 9, a região nordeste apresenta-se como a segunda maior em número de postos "bandeira branca". Tal característica permite, no capítulo seguinte, uma análise dos dados quantitativos a fim de se investigar se os preços do etanol hidratado são de fato 
competitivo em relação à gasolina C. É oportuno enfatizar que o abastecimento nos postos revendedores de combustíveis obedece ao art. $8^{\circ}$ da portaria $n^{\circ} 116$, de 5 de julho de 2000 da ANP, que regulamenta o exercício da atividade de revenda varejista de combustível automotivo, e este determina que exclusivamente as distribuidoras de combustíveis são autorizadas a suprir esses postos. Portanto, não é permitido o fluxo direto de distribuição de etanol combustível entre usinas e clientes finais no mercado interno. Sob esse aspecto, as distribuidoras exercem papel fundamental na cadeia de suprimento de combustíveis, uma vez que atuam na aquisição, no armazenamento, no transporte, na comercialização e no controle da qualidade dos combustíveis líquidos. Dessa forma, essas empresas permitem que o mercado seja adequada e economicamente suprido.

De acordo com Xavier (2008, p. 38), para que esse fluxo de etanol seja distribuído em sua forma viável de comercialização, são necessárias economias de escalas que permitam sua consolidação de cargas nas bases de distribuição, as quais geralmente estão localizadas em pontos logísticos estratégicos, de onde fazem uso dos modais de transporte mais apropriados. Na Figura 10, é possível observar as bases de distribuição, dentre elas as bases primárias e as secundárias. 


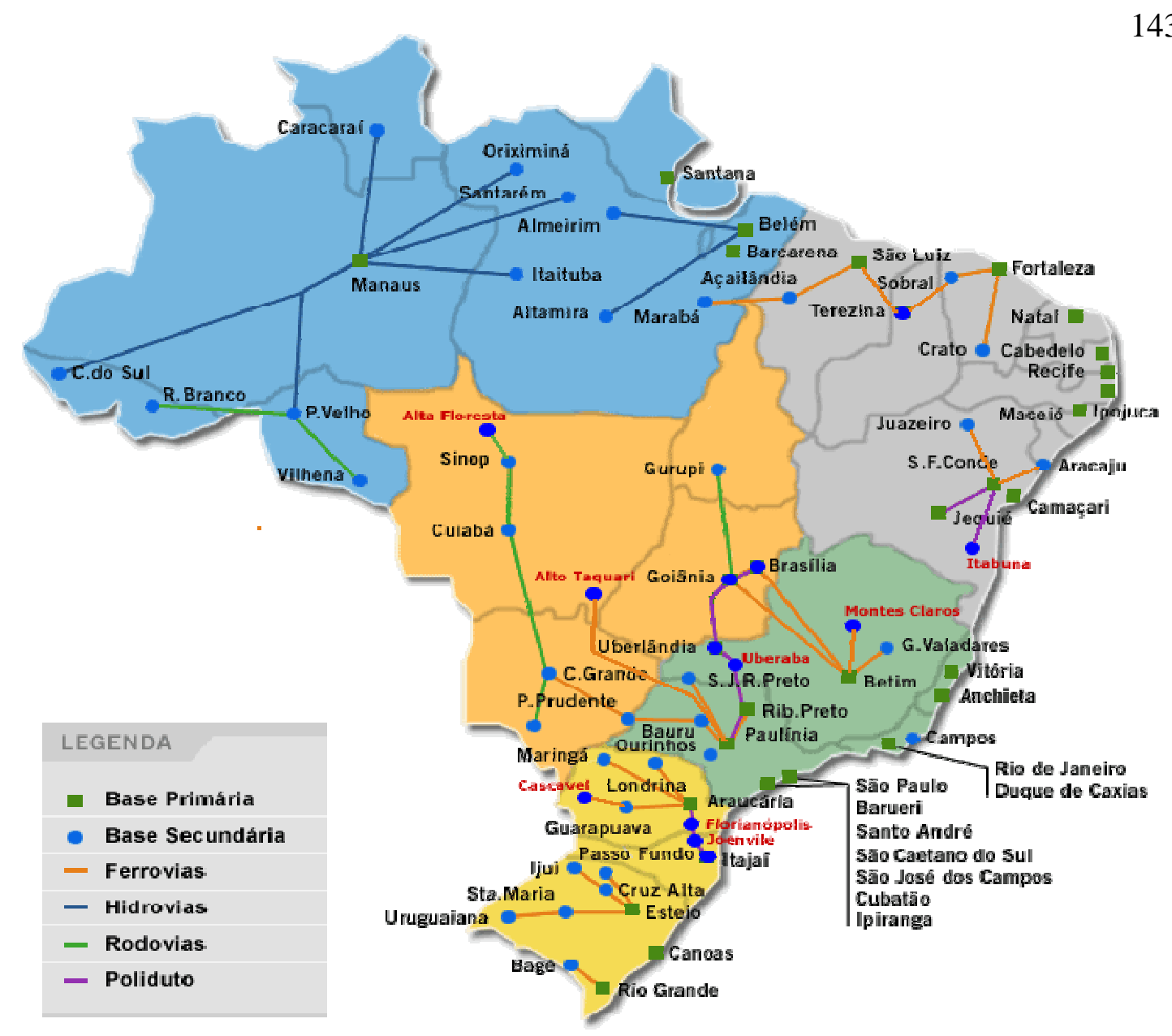

Figura 10 - Bases de Distribuição de Combustíveis Fonte: Sindicom (2010).

A distribuição do etanol no país é feita utilizando três tipos de estruturas físicas para acomodar e encaminhar esse produto: os centros coletores, as bases de distribuição primárias e as bases de distribuição secundárias. A diferença entre as bases primárias e as secundárias é dada pela proximidade às refinarias, de modo que as mais próximas são as bases primárias (usineiros e destilarias), em vista não só pela sua localização, como também pelo maior volume de combustível operado e sua elevada capacidade logística; já as bases secundárias estão espalhadas entre as unidades da Federação (distribuidoras), armazenando o recebimento proveniente da refinaria, usina ou destilaria até o posto de revenda.

Como dito anteriormente, segundo informações extraídas da ANP, até o ano de 1990, apenas 10 distribuidoras demarcavam quase que a totalidade da distribuição de etanol no país, e ao considerar que após a desregulamentação o número de distribuidoras se elevou, entende-se que o quadro atual da localização das distribuidoras no país não é uma herança da fase do Proálcool, mas sim do próprio dinamismo que o mercado consumidor e produtor no país vieram desenhando ao longo do tempo. 
Os centros coletores têm a função de receber, armazenar e encaminhar o etanol até as bases de distribuição. A Petrobras possui atualmente 10 deles, sendo 5 localizados no Estado de São Paulo e os demais espalhados para outros Estados. Estes não devem seguir até o posto de revenda, devendo necessariamente ir até a distribuidora. Conforme Figura 11, são no total 40 coletores e 19 refinadoras existentes no país.

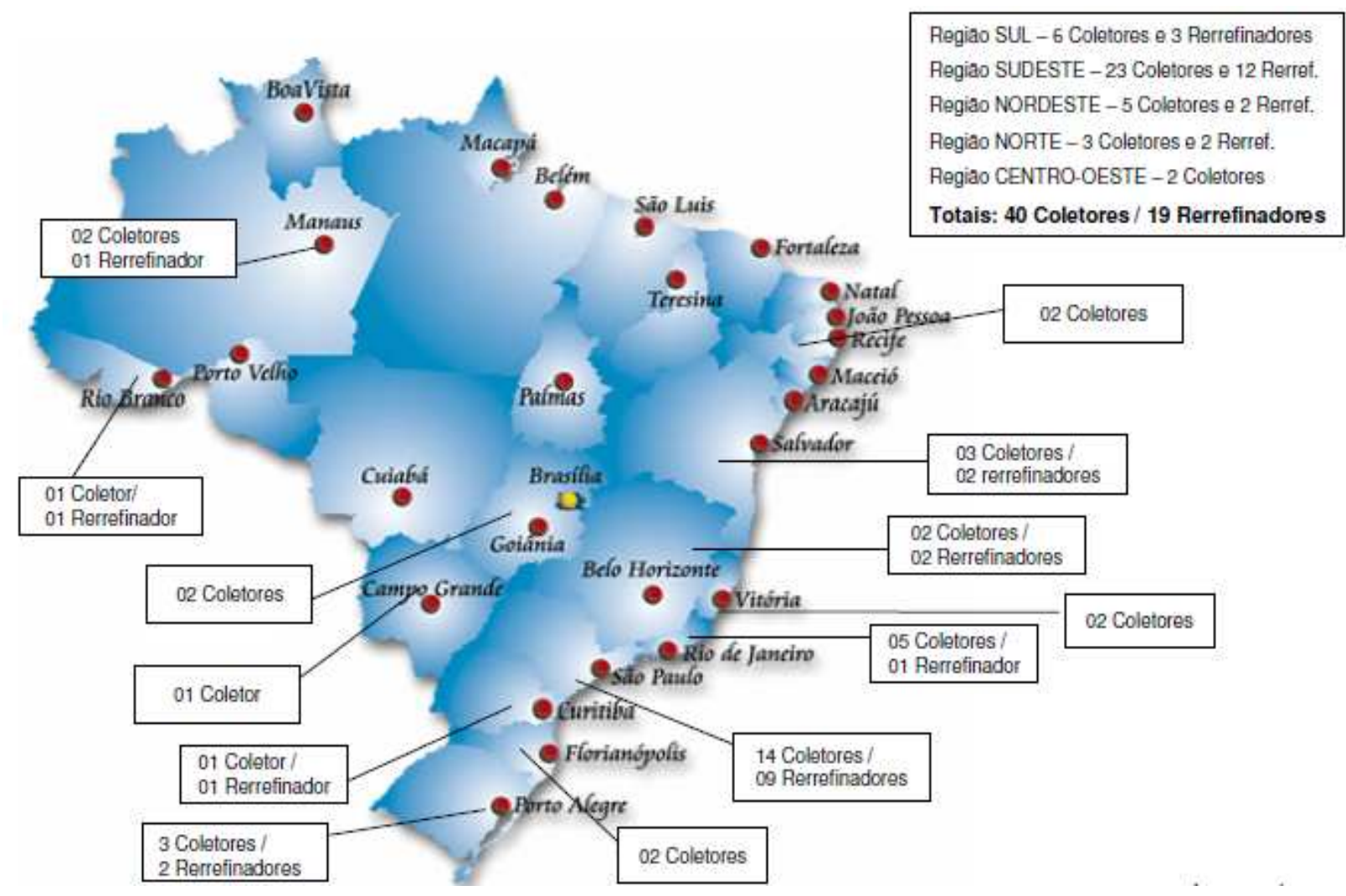

Figura 11 - Localização dos Coletores e Refinadores Fonte: ANP (2010).

A Figura 11 revela que os centros coletores, que constituem a principal base de distribuição, estão espalhados pelo país, sob a finalidade de garantir o abastecimento do etanol hidratado, e muitos destes são explorados nas operações logísticas da Petrobras por meio da BR Distribuidora. Assim, as bases distribuidoras têm a opção de coletar o etanol hidratado diretamente de seus tanques de armazenagem.

De acordo com a ANP (2010), das 508 distribuidoras, cerca de 213 apresentam-se também como bases de distribuição, que também se subdividem entre primárias e secundárias, e estão localizadas em 127 diferentes cidades, e destas 116 contam com tanques de armazenagem e distribuição de etanol hidratado, para que possam abastecer cerca os 36.730 postos de 
combustíveis no país e aos $752 \mathrm{TRR}^{10}$ (Transportadores Revendedores Retalhistas) e aos grandes consumidores rurais, empresas, caminhoneiros e automobilistas. Cumpre destacar que todas essas distribuidoras e bases possuem uma capacidade nominal de armazenamento de $718.929 \mathrm{~m}^{3}$.

Além de compreender como se dá a estruturação da demanda formada pelas distribuidoras, outra questão relevante ao entendimento da distribuição são as características da logística de escoamento do etanol hidratado para perfazer o entendimento do dinamismo da prática dos preços. Sobre esse aspecto, tem-se a Figura 12, que ilustra como se dá a rede logística de distribuição de etanol no país.

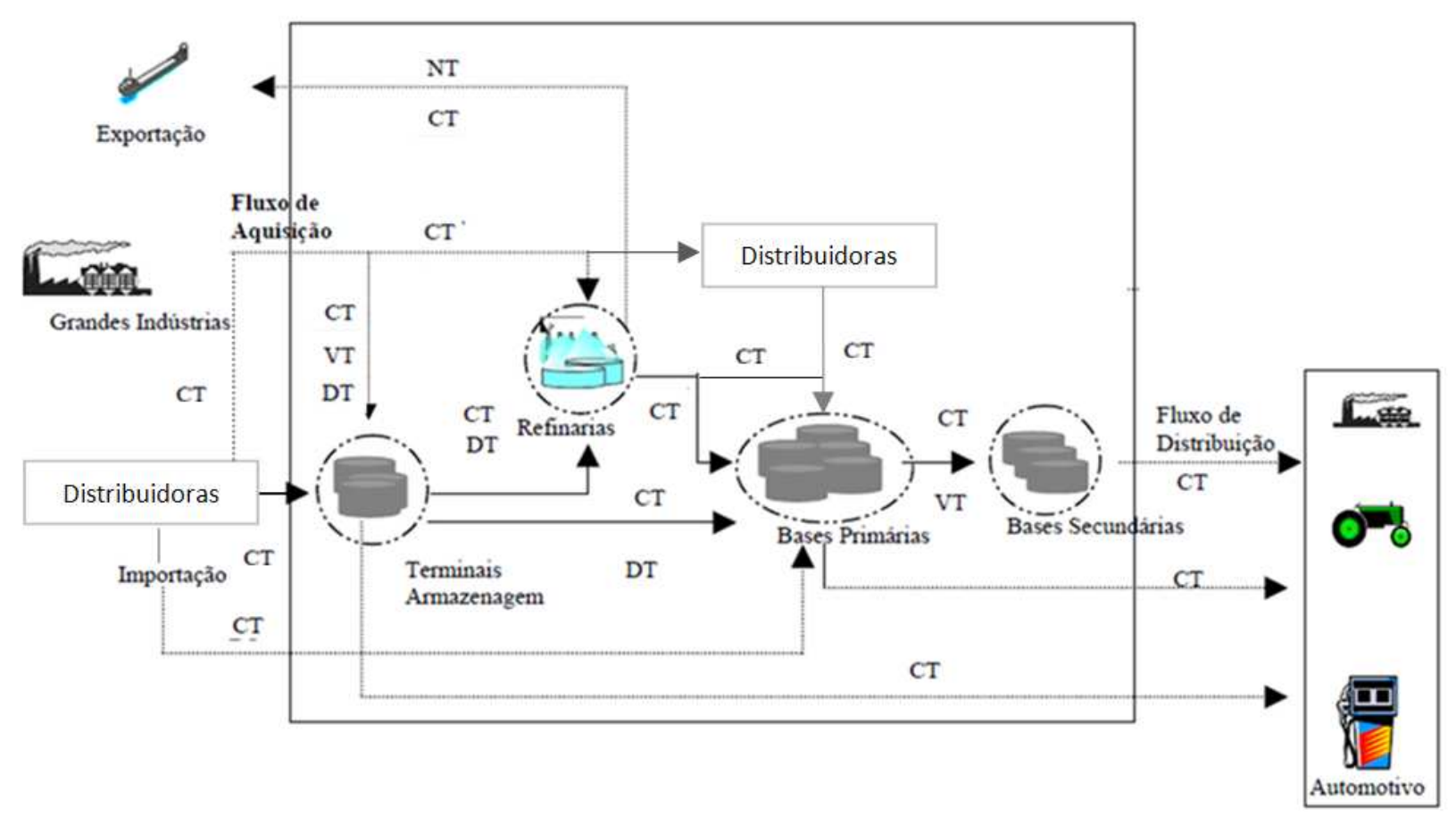

CT = Caminhão - Tanque; VT = Vagão-Tanque; DT = Duto; NT = Navio-Tanque .

Figura 12 - Configuração da Rede de Distribuição do Etanol

Fonte: Soares et al (2003, p. 02) - Adaptado pelo autor.

Nota-se, na Figura 12, que a logística de abastecimento de etanol combustível no Brasil pode ser configurada de quatro formas: caminhão-tanque, vagão-tanque, duto e navio-tanque. No mercado interno, primeiramente, o etanol sai das unidades produtoras (usinas e destilarias), passa pelas distribuidoras, terminais, refinarias e bases primárias e secundárias, seguindo para os postos revendedores, onde é então vendido aos consumidores finais, de modo que o modal

\footnotetext{
${ }^{10}$ Conforme ANP (2010), as TRR são pessoas jurídicas autorizadas para o exercício da atividade de transporte e revenda retalhista de combustíveis, exceto gasolinas automotivas, gás liquefeito de petróleo, combustíveis de aviação e etanol combustível, podendo comercializar apenas óleos, lubrificantes, graxas e querosene. Só podem adquirir de distribuidora, sendo vedada a compra direta da refinaria.
} 
que mais prevalece dentre a rede de distribuição é o caminhão-tanque. Para o caso do mercado externo, pode haver a importação do combustível ou a exportação pelas usinas e distribuidoras, em que o navio-tanque ou caminhão-tanque representam os modais utilizados.

O fluxo do etanol sai da usina, destilaria, refinaria ou terminais de armazenagem (centros coletores) em direção às bases primárias e secundárias, nas quais os modais mais utilizados são os ferroviários e os rodoviários. O fluxo do etanol hidratado entre as bases primárias para as secundárias é constituído no intuito de aproximar esses estoques do mercado consumidor, cabendo aí a necessidade de uma estrutura de tancagem/armazenagem que permita o escoamento em épocas de alta produção, para que durante as entressafras possa ocorrer o abastecimento sem que haja grandes oscilações nos preços da revenda.

\subsection{Estrutura tributária}

Nesta seção, o dinamismo dos preços do etanol hidratado é compreendido a partir da concepção dos principais impostos e como eles incidem na cadeia de combustíveis. Os impostos são incidentes na produção e comercialização. É oportuno enfatizar que, para a comercialização do etanol, a ANP deverá fornecer o Certificado de Cadastramento de Fornecedor de Etanol Combustível para fins Automotivos, e somente estando munido deste documento é que poderá o fornecedor iniciar a comercialização.

A Resolução $\mathrm{n}^{\circ}$ 05, de 13 de fevereiro de 2006, especificamente o art. 8 - trata das obrigações a que está submetido o fornecedor, como o envio dos dados de comercialização à ANP, a necessidade de guardar as notas fiscais relativas à atividade, bem como a obrigatoriedade de lacre do compartimento do veículo utilizado para o transporte do etanol combustível. Quanto ao fato da revenda, por exemplo, ter de fornecer dados da comercialização à ANP, fica a seguinte reflexão no presente estudo: por que a referida agência em seu acompanhamento dos preços médios do combustível etanol no país não se estende em sua granularidade de informações, inferindo-se a resultado da população e não de uma simples amostragem desenvolvida por uma empresa terceira responsável por pesquisar preços do mercado? O que poderia até mesmo obter informações partilhadas em níveis de preços em postos bandeirados e postos "bandeira branca". 
Já em relação ao produtor, na Medida Provisória nº 413, de 13 de janeiro de 2008, houve a introdução de várias mudanças na arrecadação tributária do país, dentre elas a contribuição ao PIS/Pasep ${ }^{11}$ e à Cofins ${ }^{12}$, especialmente no que tange às operações com etanol, onerando, sobretudo, os produtores. Pois, foi transferido para eles a parcela de PIS e Cofins que antes era recolhida pelas distribuidoras de combustíveis, por isso quando se diz ser $60 \%$ o custo de produção para o produtor, há ainda que considerar a parte significativa referente aos encargos tributários. Essa medida, conforme Sindicom (2010), eleva a alíquota do produtor de 3,65\% para até $21 \%$. Em contrapartida, a majoração que ora deve ser recolhida pelos produtores, onerando seus custos, é repassada a toda cadeia de combustíveis até a revenda, encarecendo ainda mais os preços na bomba. Assim, custos altos para o produtor comprimem sua margem de lucro, o qual, diante de situações de demanda favorável, repassa seus custos tributários em seus preços, de forma que o consumidor final na ponta da cadeia absorva o impacto de uma oneração tributária do governo. Estes são os principais tributos que incidem sobre o combustível etanol ${ }^{13}$ :

1) etanol anidro: PIS/Cofins e ICMS ${ }^{14}$ diferido para Gasolina A;

2) etanol hidratado: ICMS e PIS/Cofins.

Conforme dados da Sindicom (2010), os tributos incidentes são:

1) Para os produtores:

a) etanol anidro: PIS/Cofins e ICMS diferido para Gasolina A;

b) etanol hidratado: ICMS e PIS/Cofins.

2) Para as distribuidoras:

a) ICMS e substituição tributária na revenda PIS/Cofins.

3) Para as revendas:

a) Isentos de recolhimento (substituídos).

O PIS e a Cofins tiveram sua legislação alterada em 2008, mudando significativamente a forma de cobrança nos produtores e nas distribuidoras. As principais alterações introduzidas no PIS/Cofins, a partir de 01/10/2008, foram:

\footnotetext{
${ }^{11}$ PIS/Pasep - Programas de Integração Social e de Formação do Patrimônio do Servidor Público.

${ }^{12}$ Cofins - Contribuição para o Financiamento da Seguridade Social.

${ }^{13}$ Cabe destacar que: a CIDE - Contribuição de Intervenção no Domínio Econômico, também, é componente tributário no etanol. Porém, atualmente a CIDE, que está prevista em lei, está zerada para o etanol por Decreto Lei de $n^{\circ} 5.060 / 2004$.

${ }^{14}$ ICMS - Imposto sobre Operações relativas à Circulação de Mercadorias e Prestação de Serviços de Transporte Interestadual e Intermunicipal e de Comunicação.
} 
a) as alíquotas deixaram de ser "ad valorem" (percentual sobre o preço) e passaram a ser "ad rem" (ou específicas e que consistem em um valor fixo, em R $\$ /$ Litro);

b) as alíquotas passaram de "cumulativas" (sem direito a crédito) para "não cumulativas" (com direito a crédito);

c) os produtores e as distribuidoras passaram a ter o direito de opção entre serem tributados pelas alíquotas "ad valorem" ou "ad rem". Como as alíquotas "ad rem" são mais vantajosas, todos os contribuintes optaram por elas;

d) apenas o etanol que é exportado para outros fins não tem a incidência de PIS/Cofins.

Assim, o PIS e a Cofins, já por meio do Decreto Lei de ${ }^{\circ}$ 6.573, de 19 de setembro de 2008, que passou a vigorar em outubro do referido ano, fixam o coeficiente sobre a receita bruta auferida na venda de etanol e estabelecem os valores dos créditos dessas contribuições que podem ser descontados na aquisição de etanol anidro para adição à gasolina. As alíquotas fixas "ad rem"da contribuição para o PIS e da Cofins, que incidem sobre o etanol hidratado, distribuem-se em:

a) $R \$ 8,57$ (oito reais e cinquenta e sete centavos) e $R \$ 39,43$ (trinta e nove reais e quarenta e três centavos) por metro cúbico de etanol, no caso de venda realizada por produtor ou importador;

b) $\mathrm{R} \$ 21,43$ (vinte e um reais e quarenta e três centavos) e $\mathrm{R} \$ 98,57$ (noventa e oito reais e cinquenta e sete centavos) por metro cúbico de etanol, no caso de venda realizada por distribuidor.

Ainda de acordo com o Decreto Lei $\mathrm{n}^{\circ}$ 6.573, no caso da aquisição de etanol anidro para adição à gasolina, os valores dos créditos da contribuição para o PIS/PASEP e da Cofins ficam estabelecidos, respectivamente, em:

a) $\mathrm{R} \$ 3,21$ (três reais e vinte e um centavos) e $\mathrm{R} \$ 14,79$ (quatorze reais e setenta e nove centavos) por metro cúbico de etanol, no caso de venda realizada por produtor ou importador;

b) $\mathrm{R} \$ 16,07$ (dezesseis reais e sete centavos) e $\mathrm{R} \$ 73,93$ (setenta e três reais e noventa e três centavos) por metro cúbico de etanol, no caso de venda realizada por distribuidor.

Com relação à tributação Estadual, tem-se a incidência do ICMS, que varia significativamente dependendo do tipo, do uso e se a venda é interna ou interestadual. O ICMS é um tributo 
estadual cujas regras e alíquotas podem variar de Estado para Estado, porém algumas regras são gerais para todos os Estados, conforme Sindicom (2010), tais como:

a) para o etanol anidro, o ICMS é diferido (transferido) para a gasolina A. Ou seja, a carga tributária é toda cobrada na gasolina A e vendida pela Petrobras. O ICMS é diferido nas vendas internas (dentro do mesmo Estado) e nas vendas interestaduais (vendas entre Estados); b) para o etanol hidratado, o ICMS é cobrado por alíquotas que variam de $12 \%$ (SP) a $28 \%$ (referente ao estado do Pará);

c) para os casos do etanol para outros fins (tanto o anidro quanto o hidratado), o ICMS é cobrado por alíquotas que variam de $17 \%$ a $18 \%$ dependendo do Estado;

d) não há a incidência de ICMS nas exportações;

e) para as vendas interestaduais, segundo a Constituição Federal, as alíquotas de ICMS variam de acordo com a origem e o destino do produto, podendo ser de $7 \%$ ou de $12 \%$.

Estas alíquotas não variam entre Estados, e esta regra só não vale para o etanol anidro combustível que tem o ICMS diferido. A substituição tributária que representa a responsabilidade pelo ICMS em relação às operações ou prestações de serviços atribuídos a outro contribuinte, também, se faz presente na comercialização do etanol. Assim, há duas modalidades de contribuintes: o contribuinte substituto, que é aquele eleito para efetuar a retenção e/ou recolhimento do ICMS; e o contribuinte substituído, que representa aquele que, nas operações ou prestações antecedentes ou concomitantes, é beneficiado pelo diferimento do imposto e nas operações ou prestações subsequentes sofre a retenção, onerando-se os preços, que é o caso das revendas. A Tabela 10, a seguir, revela a aplicação do ICMS dentre os diversos Estados do país. 
Tabela 10 - Alíquota do ICMS em 2010 (\%)

\begin{tabular}{lcccccccccc}
\hline UF & \multicolumn{2}{c}{ Gasolina } & Diesel & Biodiesel & $\begin{array}{c}\text { QAV-1 } \\
\text { Dom. }\end{array}$ & Intern. & $\begin{array}{c}\text { Querosene } \\
\text { Ilumin. }\end{array}$ & $\begin{array}{c}\text { Óleo } \\
\text { Comb. }\end{array}$ & G.N.V. & $\begin{array}{c}\text { Etanol } \\
\text { Hidrat. }\end{array}$ \\
\hline AC & 25 & 25 & 17 & 12 & 25 & 0 & 17 & 17 & 17 & 25 \\
AL & 27 & 25 & 17 & 12 & 17 & 0 & 17 & 17 & 12 & 27 \\
AM & 25 & 25 & 17 & 12 & 25 & 0 & 17 & 17 & 17 & 25 \\
AP & 25 & 25 & 17 & 12 & 25 & 0 & 17 & 17 & 17 & 25 \\
BA & 27 & 27 & 15 & 12 & 17 & 0 & 17 & 17 & 12 & 19 \\
CE & 27 & 25 & 17 & 12 & 25 & 0 & 17 & 17 & 17 & 25 \\
DF & 25 & 25 & 12 & 12 & 25 & 0 & 25 & 25 & 25 & 25 \\
ES & 27 & 25 & 12 & 12 & 25 & 0 & 17 & 17 & 17 & 27 \\
GO & 26 & 26 & 12 & 12 & 15 & 0 & 17 & 17 & 17 & 20 \\
MA & 27 & 25 & 17 & 12 & 25 & 0 & 17 & 25 & 17 & 25 \\
MG & 25 & 25 & 12 & 12 & 4 & 0 & 18 & 18 & 18 & 25 \\
MS & 25 & 25 & 17 & 12 & 17 & 0 & 17 & 17 & 12 & 25 \\
MT & 25 & 25 & 17 & 12 & 25 & 0 & 17 & 17 & 17 & 25 \\
PA & 30 & 30 & 17 & 12 & 17 & 0 & 17 & 17 & 17 & 28 \\
PB & 27 & 25 & 17 & 12 & 17 & 0 & 17 & 17 & 17 & 25 \\
PE & 27 & 25 & 17 & 12 & 25 & 0 & 17 & 17 & 17 & 25 \\
PI & 25 & 25 & 17 & 12 & 27 & 0 & 17 & 20 & 17 & 25 \\
PR & 28 & 26 & 12 & 12 & 18 & 0 & 17 & 17 & 12 & 18 \\
RJ & 31 & 31 & 13 & 12 & 4 & 0 & 19 & 19 & 12 & 24 \\
RN & 25 & 25 & 17 & 12 & 17 & 0 & 17 & 17 & 12 & 25 \\
RO & 25 & 25 & 17 & 12 & 25 & 0 & 17 & 17 & 17 & 25 \\
RR & 25 & 25 & 17 & 12 & 25 & 0 & 17 & 17 & 17 & 25 \\
RS & 25 & 17 & 12 & 12 & 17 & 0 & 17 & 17 & 12 & 25 \\
SC & 25 & 25 & 12 & 12 & 17 & 0 & 17 & 17 & 12 & 25 \\
SE & 25 & 27 & 17 & 12 & 17 & 0 & 17 & 17 & 17 & 27 \\
SP & 25 & 25 & 12 & 12 & 25 & 0 & 18 & 18 & 12 & 12 \\
TO & 25 & 14 & 12 & 12 & 17 & 0 & 17 & 17 & 17 & 25 \\
\hline TOTAL & $\mathbf{2 6 , 0 5}$ & $\mathbf{2 4 , 4 7}$ & $\mathbf{1 3 , 4 4}$ & $\mathbf{1 2 , 0 0}$ & $\mathbf{1 8 , 8 8}$ & $\mathbf{0}$ & $\mathbf{1 7 , 3 5}$ & $\mathbf{1 7 , 5 4}$ & $\mathbf{1 2 , 7 8}$ & $\mathbf{1 7 , 2 6}$ \\
\hline & & & & & & & 0 & & \\
\end{tabular}

Fonte: Sindicom (2010).

A tabela anterior demonstra que, no Estado de São Paulo, o ICMS para o etanol hidratado é de $12 \%{ }^{15}$, o menor dentre todos os Estados. Trata-se de uma política tributária do Estado com objetividade de ganhos de escala na arrecadação, e pelo fato de ser baixo não motiva fraudes por substituição tributária. Deve-se considerar que o Estado de São Paulo, também, concentra a maior frota de veículos movidos a etanol hidratado do país, além da maior parte dos produtores.

Para o Estado de São Paulo, a baixa incidência do ICMS em relação aos outros Estados não

\footnotetext{
${ }^{15}$ A Lei Estadual $n^{\text {o }} 11.593$ de 04.12.2003, publicada em 05.12.2003, que já entrou em vigor na data de sua publicação, reduziu de $25 \%$ para $12 \%$ a alíquota do ICMS que incide sobre Etanol Hidratado Carburante.
} 
compromete seu orçamento, já que sua frota de veículos é significante, em torno de 5,4 milhões entre etanol e flex, conforme dados de 2010 do Departamento Nacional de Trânsito Denatran. Do ponto de vista tributário, é compensadora ao produtor a comercialização de etanol anidro, já que é menos oneroso, por conta da isenção do ICMS (não é tributado na saída da usina). Assim, um detalhe importante na questão tributária é quanto à configuração do etanol, se anidro ou hidratado, pois a composição tributária se distingue, e somente será definido se será caracterizado como combustível ou para outros fins no momento da venda. Se for para fins de uso na indústria química, o imposto ICMS para o etanol anidro é isento no referido Estado. Mas, se for para fins carburantes, o etanol anidro, ao entrar na composição da gasolina, tem a incidência da alíquota de ICMS de $25 \%$.

De acordo com o Sindicom (2010), no caso da gasolina, esse já sai da refinaria com todos os impostos federais e estaduais cobrados, pelo sistema de substituição tributária. Já as usinas de etanol só recolhem a sua parte dos tributos, e os distribuidores devem recolher o restante. Ou seja, esse instrumento fiscalizador antecipa a arrecadação aos cofres públicos recolhidos junto às usinas/destilarias produtoras de etanol; em contrapartida, obriga um desembolso financeiro antecipado para os contribuintes, que, por sua vez, se estende às distribuidoras que posteriormente recai sobre a revenda (posto de combustível no qual o consumidor final absorve esses custos tributários). Ademais, os estabelecimentos substitutos, usinas/destilarias, sofrem um desembolso financeiro praticamente imediato pela antecipação do recolhimento do ICMS devido pelo substituído (bases distribuidoras), e o prazo para recebimento dos valores das vendas é normalmente muito superior ao vencimento do ICMS retido na substituição. Assim, por mais que seja repassado à distribuidora e à refinaria, o prazo esperado pela usina pelo tributo pago é longo, sendo, portanto, contemplado para alguns produtores como custos, impactando, assim, em sua formação de preço.

Faz-se valer o entendimento sobre a prática do recolhimento do imposto, que pode variar de Estado para outro. No caso do Estado de São Paulo, o Decreto Lei $\mathrm{n}^{\mathrm{o}}$ 54.976, de 29 de outubro de 2009, apresenta:

Artigo 418 - Na saída de álcool etílico (etanol) hidratado carburante com destino a estabelecimento localizado em território paulista, fica atribuída a responsabilidade pelo pagamento do imposto devido nas operações subsequentes até o consumo final; 
Acrescenta-se ainda, de acordo com o mesmo decreto, que na falta do preço máximo ou único de venda a consumidor fixado por autoridade competente, a base de cálculo será o montante formado pelo preço estabelecido por autoridade competente para o sujeito passivo por substituição tributária, ou, em caso de inexistência deste, pelo valor da operação acrescido dos valores correspondentes a frete, seguro, tributos, contribuições e outros encargos transferíveis ou cobrados do destinatário, adicionados, ainda, em ambos os casos, do valor resultante da aplicação dos percentuais de margem de valor agregado divulgados mediante Ato da Comissão Técnica Permanente (COTEPE) a ser publicado no Diário Oficial da União.

Entende-se, portanto, que o preço do etanol hidratado comprado pelas distribuidoras nas destilarias e usinas já inclui o ICMS, PIS/Pasep e a Confins. Cabe às distribuidoras, ao venderem o etanol hidratado, recolherem, como contribuintes substitutos, o ICMS devido pelos revendedores, postos de combustíveis. Quando a distribuidora vende o etanol hidratado para um revendedor situado em outro Estado, ela recolhe a parcela que deverá ser remetida ao Estado produtor.

Com relação ao etanol anidro, não há incidência do ICMS na operação de sua aquisição pelas distribuidoras às destilarias e usinas. Sobre essa operação somente incidem as contribuições para o PIS/Pasep e a Cofins. Ou seja, o ICMS do etanol anidro é recolhido juntamente com o ICMS da gasolina A, uma vez que a margem de lucro presumido da gasolina A, utilizada na formação da base de cálculo do ICMS para efeito da substituição tributária, já considera a adição do etanol anidro à gasolina A para constituição da gasolina C. As distribuidoras devem declarar às refinarias a origem do etanol anidro adquirido para o repasse do imposto ao Estado produtor do etanol. Assim, nos casos tanto do etanol anidro como de hidratado, o montante de ICMS arrecadado cabe aos Estados produtores e não aos receptores dos produtos, diferentemente do que ocorre com os demais combustíveis (ANP, 2010).

\subsection{Capacidade física de armazenagem}

Esta seção analisa a capacidade física de armazenagem do etanol hidratado no país, sob o pressuposto de que esse possa ser também fator qualitativo no dinamismo dos preços praticados na revenda, uma vez que a falta desse tipo de infraestrutura poda ser desencadeador de custos, e, por conseguinte, de altas nos preços. 
Inicialmente, deve-se ressaltar que são dois tipos de armazenagem de etanol no país. Segundo Xavier (2008), o primeiro trata-se da existência dos tanques de combustíveis pertencentes às usinas produtoras de etanol. Esse conjunto possui como função básica armazenar o excedente de produção dos combustíveis ao longo da safra agrícola, decorrente da sazonalidade de produção do etanol. Já o segundo refere-se à rede de armazenagem de etanol que consiste dos tanques das distribuidoras e, em menor escala, dos terminais portuários, dos terminais da Petrobras Transporte S.A. - Transpetro, e dos centros coletores de etanol. Em ambos os tipos, não há o objetivo, atualmente, segundo ANP (2010), de prover estoques de segurança para suprir o abastecimento interno de etanol hidratado em épocas de entressafras. Assim, a principal finalidade dos tanques de armazenagem é atender o abastecimento interno no curtoprazo, ou então prover armazenamento para o serviço de transporte de combustíveis via terminais.

A Petrobras, vista anteriormente em épocas de intervenção (Proálcool), quando exercia a responsabilidade logística, atuando com subsídios, detinha também a incumbência de preservar e manter os tanques de armazenagem. Souza (2006, p. 30) revela que a Petrobras, durante a fase de intervenção, possuía uma infraestrutura capaz de armazenar 1,3 milhões de $\mathrm{m}^{3}$. Com a desregulamentação, o autor revela que a BR Distribuidora, responsável pela formação dos estoques estratégicos (estoques reguladores), deixou de fazê-los, de modo que a formação desses estoques e seus investimentos em ampliação e manutenção passaram a ser de responsabilidade dos produtores, de acordo com seus interesses comerciais, tal como ocorre atualmente. Ainda em seus estudos, foi observado que existem dúvidas se a organização da infraestrutura de armazenagem de etanol é adequada à formação dos estoques estratégicos caso ocorra a necessidade, sobretudo em período de entressafra. Para as usinas ou destilarias, investir na construção de novos tanques para fins de estoque estratégico implicaria em elevados custos, por isso argumentam que há a necessidade de uma maior participação governamental nesses investimentos.

De acordo com as estimativas de Xavier (2008, p. 107), uma usina possui capacidade de armazenagem de até $50 \%$ da sua produção anual de etanol, algo em torno de 8,5 milhões de $\mathrm{m}^{3}$. Essa capacidade de armazenagem deve ser alocada separadamente, etanol hidratado e etanol anidro, pelas unidades produtoras. E, por outro lado, as bases de distribuição têm a função de terminais de armazenagem, viabilizando a movimentação do etanol hidratado por 
meio do recebimento, expedição e armazenagem. $\mathrm{O}$ autor enfatiza também que a capacidade de armazenagem total das distribuidoras foi próxima a 3,75 milhões de $\mathrm{m}^{3}$, no ano de 2008 , destes o etanol ocupa $725 \mathrm{mil} \mathrm{m}$ (19,4\% do total), divididos em $300 \mathrm{mil} \mathrm{m}^{3}$ para anidro e 425 mil $\mathrm{m}^{3}$ para hidratado, o equivalente a quase 20 dias de consumo do mercado. Esse ponto revela que existe a necessidade de novos investimentos na capacidade de armazenagem de toda a rede distributiva do país, pois considerando que o período de entressafra, segundo a UNICA (2010), é de 3 a 4 meses, logo há um gargalo de abastecimento ao redor de 3 meses, que possivelmente implica em oscilações dos preços no mercado interno. E um aumento de produtividade ou de expansão agrícola, sem investimentos em tancagem, não resolveriam as oscilações dos preços no curto prazo.

Xavier (2008), ainda, constatou em seus estudos que o estoque médio de etanol combustível nas distribuidoras corresponde a duas semanas de consumo da sua região de abrangência. Para o caso de distribuidoras próximas às regiões produtoras, o estoque equivale a uma semana de consumo, enquanto, nas regiões mais distantes dos centros produtores, esse estoque não supera quatro semanas de consumo. Isso evidencia, portanto, que nas distribuidoras, sobretudo às próximas das usinas e destilarias, o tempo de estocagem é curtíssimo, e, por conseguinte, em épocas de entressafra o impacto na elevação de preços é mais sensível que nas regiões mais distantes da Centro-Sul. Ou seja, por isso tem-se a sensação de que os preços em entressafras são mais sensíveis ou perceptíveis na revenda, em sua elevação, que em outras localidades onde o estoque dura um pouco mais, o que revela a carência em níveis de investimentos nesse tipo de infraestrutura na região Centro-Sul, onde a frota de veículos flex é bem maior.

Em paralelo, Zanão (2009, p. 48) destaca as unidades produtoras, sendo estas no ano de 2008 capazes de estocar $11.626 .512 \mathrm{~m}^{3}$. Deste total, a capacidade de tancagem para o etanol anidro é de $5.274 .582 \mathrm{~m}^{3}$, representando $45 \%$ do total - e para o etanol hidratado é de $6.351 .939 \mathrm{~m}^{3}$. Considerando que o etanol ocupa $725 \mathrm{mil} \mathrm{m}^{3}$ de capacidade de armazenagem em toda a cadeia. Os produtores, portanto, operam com apenas 1,6\% de capacidade de estocagem. E, comparando-se com a capacidade apenas em relação às distribuidoras, que é de $578 \mathrm{mil} \mathrm{m}^{3}$, segundo a ANP (2010), os produtores representam somente $2 \%$, revelando que não estão aptos à possível necessidade de estocagem se houver aumento produtivo de etanol hidratado no país. A seguir, a Tabela 11 apresenta a capacidade nominal de armazenagem nas diversas 
regiões do país, possibilitando observar onde se concentra a maior e menor tancagem.

Tabela 11 - Quantidade de bases de distribuição de combustíveis líquidos derivados de petróleo e de etanol automotivo, segundo Grandes Regiões e Unidades da Federação, em 31/12/2009

\begin{tabular}{|c|c|c|}
\hline $\begin{array}{c}\text { Grandes Regiões e Unidades da } \\
\text { Federaçãa }\end{array}$ & $\begin{array}{l}\text { Quantidade de bases de } \\
\text { distribuição }\end{array}$ & $\begin{array}{c}\text { Capacidade nominal } \\
\text { de armazenamento }\left(\mathrm{m}^{3}\right) \\
\text { Etanol }\end{array}$ \\
\hline Brasil & 508 & 578.153 \\
\hline Região Norte & 56 & 44.523 \\
\hline Rondônia & 12 & 10.228 \\
\hline Acre & 5 & 2.458 \\
\hline Amazonas & 8 & 13.121 \\
\hline Roraima & 2 & 1.611 \\
\hline Pará & 24 & 14.818 \\
\hline Amapá & 1 & 1.184 \\
\hline Tocantins & 4 & 1.103 \\
\hline Região Nordeste & 74 & 98.317 \\
\hline Maranhão & 8 & 22.022 \\
\hline Piauí & 1 & 4.681 \\
\hline Ceará & 11 & 15.073 \\
\hline Rio Grande do Norte & 4 & 867 \\
\hline Paraíba & 4 & 9.501 \\
\hline Pernambuco & 12 & 21.717 \\
\hline Alagoas & 4 & 4.529 \\
\hline Sergipe & 3 & 2.826 \\
\hline Bahia & 27 & 17.101 \\
\hline Região Sudeste & 204 & 299.031 \\
\hline Minas Gerais & 34 & 45.151 \\
\hline Espírito Santo & 8 & 9.960 \\
\hline Rio de Janeiro & 30 & 57.088 \\
\hline São Paulo & 132 & 186.832 \\
\hline Região Sul & 110 & 85.179 \\
\hline Paraná & 57 & 47.506 \\
\hline Santa Catarina & 22 & 6.428 \\
\hline Rio Grande do Sul & 31 & 31.245 \\
\hline Região Centro-Oeste & 64 & 51.103 \\
\hline Mato Grosso do Sul & 12 & 9.124 \\
\hline Mato Grosso & 24 & 12.589 \\
\hline Goiás & 18 & 18.843 \\
\hline Distrito Federal & 10 & 10.547 \\
\hline
\end{tabular}

Fonte: ANP/SAB, conforme as Portarias ANP n ${ }^{\circ} 29 / 1999$ e n 202/1999.

Observa-se na Tabela 11 que com capacidades menores encontram-se os Estados do Rio Grande do Norte, com $867 \mathrm{~m}^{3}$, e Tocantins, com $1.103 \mathrm{~m}^{3}$. Já como Estados com maior capacidade de armazenagem destacam-se São Paulo e Rio de Janeiro, com respectivamente $186.832 \mathrm{~m}^{3}$ e $57.088 \mathrm{~m}^{3}$. Paralelamente, conforme dados dos preços médios do etanol 
hidratado praticados na revenda no ano de 2009, conforme a ANP (2010), entre os Estados do Rio Grande do Norte, Tocantins, São Paulo e Rio de Janeiro, foram respectivamente: R\$ $1,825, \mathrm{R} \$ 1,742, \mathrm{R} \$ 1,336$ e $\mathrm{R} \$ 1,683$. Observa-se que a diferença dos preços entre Rio Grande do Norte e Rio de Janeiro é equivalente a $8 \%$, não tão significativa se comparada às diferenças entre as capacidades de armazenagem que correspondem a 98\%. Assim, a variável capacidade de armazenagem pode apresentar seu efeito na oscilação dos preços em épocas sazonais, uma vez que pela média não é possível constatar relação direta, o que justifica a análise de regressão linear múltipla a ser analisada no capítulo seguinte, quando múltiplas variáveis serão correlacionadas com o preço médio do etanol hidratado, como, por exemplo, a frota. As regiões Norte e Nordeste possuem, em média, uma capacidade de armazenagem de $75 \%$, além do fato de tais regiões não estarem no eixo Centro-Sul de produção e terem ganhos de escala de produtividade de etanol hidratado. Segundo dados da Conab (2008), as usinas localizadas na região Norte-Nordeste possuem longa tradição na produção de açúcar. Já no Estado de São Paulo, a capacidade de estocagem é de aproximadamente 32\% referente a toda a capacidade do país, levando-se em consideração que se trata do maior Estado produtor.

Para Zanão (2009, p. 58), a estrutura relacionada à capacidade de estocagem de etanol hidratado existente nos Estados é relativamente alta, de modo que as oscilações em preços ocorrem significativamente em épocas de entressafra, ou seja, durante os meses de janeiro a abril, quando não há estoque suficiente para atender a demanda sinalizada pela respectiva frota de veículos.

Com relação às bases distribuidoras, é possível observar na Tabela 10 uma maior concentração de bases distribuidoras na região Centro-Sul brasileira, principalmente por estarem geralmente próximas das fontes supridoras diretas de combustíveis, como refinarias, usinas e destilarias, e também próximas a conexões de modais de transporte, como ferrovias, hidrovias e dutovias, nestes as bases de distribuição que mais prevalece é a primária (responsável por recepcionar o combustível entregue pelos produtores). E, de acordo com Zanão (2009, p. 64), as bases de distribuição secundárias exercem uma função de concentração e recepção de carga para posterior repassagem e encontram-se distribuídas de maneira mais homogênea no país.

Entende-se que, apesar da capacidade de armazenagem, das bases das distribuidoras de 
combustíveis, sejam primária, sejam secundárias, estarem distribuídas de acordo com a produção do Estado, essas estruturas não possuem como objetivo de negócio a manutenção de estoque como excedente de produção (estoque estratégico), uma vez que sua principal função está associada a um estoque para as operações das atividades de comercialização de combustíveis. E, segundo Caixeta-Filho (2008, p. 05-08), investimentos têm ocorrido para o aumento da capacidade de tancagem de etanol, principalmente no entorno das usinas, e esses investimentos são necessários para que o crescimento do setor seja sustentável.

\subsection{Formação de preços}

Na revisão da literatura do Capítulo 3, verificou-se que o setor de combustíveis do Brasil, mais especificamente o setor sucroenergético, passou por um elevado grau de intervenção do governo, e que, após a desregulamentação, a demanda foi estimulada pelo flex e a alternativa na redução dos custos implica no melhoramento genético, na ampliação produtiva e na estrutura de distribuição, bem como nas possibilidades de usos alternativos (eteno e farneceno).

Uma análise da formação de preços do etanol, apontada nos estudos de Marjotta-Maistro (2002, p. 109), revela que, durante os anos de 1938 a 1990, as diretrizes da política de preços dos derivados de petróleo comercializados no mercado interno foram: tabelamento dos preços em função dos interesses da economia nacional; garantia de êxito para a indústria nacional do refino de petróleo e a prática, quando possível, de preços uniformes em todo o país. Somente após 1990, a estrutura de preços desses derivados foi estabelecida de forma a propiciar cobertura dos custos dos diversos agentes econômicos envolvidos na produção, distribuição e comercialização desses produtos (refinaria, companhias de distribuição e postos de revenda). Evidencia-se, portanto, que, durante a intervenção, era determinado um preço homogêneo em todas as regiões do país, de modo que as oscilações que haviam numa determinada região eram seguidas pelas demais. Para a autora, o governo estabelecia um preço uniforme para os combustíveis em todos os postos do Brasil, independentemente de sua distância à base de distribuição supridora ou da complexidade da cadeia de suprimentos desde a região produtora. A estrutura de preços baseava-se no sistema de ressarcimento de fretes, que funcionava como um fundo de compensação em que todos os fretes eram ressarcidos às distribuidoras pelo governo, que, por sua vez, recolhia uma alíquota incidente no preço dos combustíveis para 
compor a receita deste fundo. Essa alíquota era também um mecanismo vital na regulação dos preços, pois o governo agia praticando alíquotas diferenciadas, sendo maiores em regiões próximas dos produtores e menores nas regiões mais distantes, comportando-se de forma inversa ao custo do frete, obtendo-se, portanto, um custo final uniforme em todo o território nacional.

Conforme Araújo (2006, p. 29), assim como os custos de fretes, os custos com armazenagem e estoques também eram ressarcidos às distribuidoras pelo governo. Em paralelo, os estudos de Maligo (2005, p. 41-42) apontam que a estrutura de preços trazia embutida a necessidade de fixar rotas e modais de transporte, para que o governo controlasse os ressarcimentos dos fretes. O órgão do governo responsável por esse controle era o Departamento Nacional de Combustíveis (DNC), atualmente extinto com a criação da ANP. Esse antigo órgão do governo fixava os municípios de origem e destino autorizados, o que visava determinar a localização das bases de distribuição de combustíveis, uma vez que uma base que não estivesse localizada em município autorizado não teria o direito ao ressarcimento dos fretes correspondentes à sua movimentação, tornando sua operação economicamente inviável.

Assim sendo, o consumo das regiões mais próximas aos produtores subsidiava o consumo das regiões distantes. Marjotta-Maistro (2002, p. 109) revela que o preço de realização dos combustíveis era formado pelo preço de realização do mês anterior, pela variação das cotações do mercado internacional de petróleo tipo Brent (refere-se ao óleo produzido no mar do Norte, negociado na bolsa de Londres, e sua cotação é publicada diariamente pela Platt's Crude Oil Marketwire), e também pelo petróleo WTI (significa West Texas Intermediate, negociado na bolsa de Nova York), e pela variação da taxa de câmbio. Esse preço compunha, juntamente com os impostos, o preço ditado pelo governo, o chamado preço de portaria. $\mathrm{O}$ preço de portaria entrava no cômputo do preço pago pelas distribuidoras na refinaria pela gasolina A. Contudo, os preços no mercado de combustíveis tiveram como marco da desregulamentação o ano de 2002, em que todos os preços deixaram de ser controlados pelo governo. Ademais, esse período foi importante por caracterizar as alterações nas sistemáticas de controle de preços dos combustíveis dentre os diversos atores da cadeia sucroenergética.

Essa estrutura não vigora mais no mercado de combustíveis do etanol, o que permitiu compreender preliminarmente a razão das oscilações dos preços, dado que a estrutura na 
distribuição e a composição dos custos são diferentes entre os agentes do setor do etanol. $\mathrm{Ou}$ seja, após a intervenção, a prática dos preços é adotada por cada agente do setor, ao qual vincula os seus respectivos custos, e não mais é associada diretamente à cotação do petróleo. Assim, a estrutura que se tem no cômputo do etanol considera os custos de produção de cana em várias regiões do país. Obtendo os custos da gasolina $\mathrm{A}$ e do etanol anidro, chega-se ao preço final de uma gasolina $\mathrm{C}$, por exemplo, formado em uma refinaria. Portanto, quando há um aumento no preço do etanol anidro, promovido pelo produtor, este é absorvido pela refinaria, que, mantendo os níveis de adição de $25 \%$ de mistura na gasolina A, se depara com a necessidade de reajustar seus custos e, por conseguinte, o preço da gasolina $\mathrm{C}$.

Nos estudos de Costa (2001, p. 23) o etanol hidratado, após a fase de intervenção do governo, apresenta sua formação de preços ao consumidor final de acordo com a sensibilidade dos preços pagos em toda cadeia. Ou seja, os preços destinados ao consumidor final de etanol eram formados a partir dos preços pagos aos produtores acrescidos dos custos de frete, de mistura (no caso do etanol anidro) e impostos. Especificamente no caso do etanol anidro, o preço ao consumidor final estava no preço da gasolina $\mathrm{C}$, ou seja, após o anidro ter sido misturado à gasolina $\mathrm{A}$, o produto final, a gasolina $\mathrm{C}$, era faturado.

Observa-se, desse modo, que o problema deixado após o período da regulamentação está associado à logística nas distribuidoras, uma vez que a localização da infraestrutura era determinada pelo governo, assim como a prática dos tributos, os quais oneram o preço final dos produtos. E, atualmente, em época de entressafra, a logística e sua respectiva capacidade de armazenagem demonstram a carência em que o setor se encontra e, por conseguinte, apresentam variáveis significativas nas oscilações dos preços. Nesse contexto, os preços do etanol anidro ou hidratado são negociados livremente entre os produtores e as distribuidoras, e essa prática de comercialização vigora até os dias de hoje. Decorrente disso, e agora tendo o preço como o principal determinante da demanda no mercado do etanol, espera-se que, somados aos objetivos com as reduções de emissões de gases poluentes, esforços possam ser definitivamente determinados no sentido de estabelecer o etanol como alternativa viável e sustentável no mercado global, a tal ponto de torná-lo uma commodity. Cabe enfatizar que, em uma constatação observada no setor, atualmente, os preços do etanol são formados com base nos preços do açúcar à vista, e sendo o açúcar uma commodity e aceito no mercado global; logo, em uma mesa de negociação de uma trade, define-se a oferta e o preço de etanol 
no mercado interno. Já que o açúcar tem seu uso global e o etanol carburante, ao contrário, ainda de forma tímida. Além disso, outras fronteiras ainda necessitam ser parametrizadas, como a difusão da tecnologia flex e a expansão produtiva do etanol no mercado global.

Com relação ao mercado global, vale destacar, segundo Kojima et al (2007), que o etanol é classificado como um produto agrícola. Tal classificação é polêmica, uma vez que os países interessados na exportação dos biocombustíveis tenderão a classificá-lo como um bem industrial, pois este possui barreiras mais flexíveis às exportações. Já aqueles países interessados em proteger o seu mercado das importações tenderão a classificá-lo como um produto agrícola, mercado tradicionalmente distorcido por subsídios e barreiras comerciais. Contudo, não é possível negar o fato de que a commodity do etanol venha ser uma realidade futura na determinação de preços, uma vez que sua determinação ambiental se apresenta viável às reduções nas emissões de poluentes.

Com relação à prática dos preços, Feijó e Alvim (2008, p. 70) destacam que os consumidores são extremamente sensíveis ao diferencial de preços entre gasolina e etanol hidratado, e migram de um produto para o outro rapidamente, com impactos sobre a demanda de etanol no mercado interno. E o principal determinante dentre a decisão do consumidor final fica ao patamar de $70 \%$ o preço relativo entre etanol hidratado e a gasolina $\mathrm{C}$, de modo que se o etanol tiver seu preço final na bomba superior a $70 \%$ do preço final da gasolina $\mathrm{C}$, a decisão é pelo consumo da gasolina C, essa constatação é afirmada por Goldemberg et al (2008).

Na ótica de Nogueira (2008, p. 44-47), o preço da gasolina tem contribuído para determinar o preço do etanol no Brasil, estabelecendo um teto a ser respeitado pelos produtores interessados em proteger seu mercado consumidor. Esse mercado conta com um crescente número de veículos flexíveis, que poderão migrar para a gasolina caso o preço do etanol ao consumidor, por litro, ultrapasse cerca de $70 \%$ do preço da gasolina nos postos revendedores. Em contrapartida, o preço do etanol também limita a elevação do preço da gasolina, já que os consumidores que, eventualmente, usam gasolina deixarão de fazê-lo caso o etanol lhes pareça mais atrativo. $\mathrm{O}$ autor, ainda, sustenta que essa arbitragem exercida pelo consumidor leva em conta os custos finais na utilização dos combustíveis, que são, por sua vez, uma consequência das diferenças de consumo por quilômetro percorrido. A Tabela 12 apresenta as variações de preços médios do etanol hidratado após a desregulamentação do governo: 
Tabela 12 - Preço médio do etanol hidratado ao consumidor, segundo Grandes Regiões e Unidades da Federação: 2001-2010

\begin{tabular}{|c|c|c|c|c|c|c|c|c|c|c|}
\hline Regiões e U.F. & $2001^{1}$ & 2002 & 2003 & 2004 & 2005 & 2006 & 2007 & 2008 & 2009 & 2010 \\
\hline Brasil & 1,025 & $\mathbf{1 , 0 3 8}$ & 1,347 & 1,212 & 1,377 & 1,676 & 1,492 & 1,484 & $\mathbf{1 , 5 2 0}$ & 1,660 \\
\hline Região Norte & 1,283 & 1,311 & 1,764 & 1,644 & 1,861 & 2,152 & 1,927 & 1,925 & 1,920 & 2,067 \\
\hline Rondônia & 1,252 & 1,306 & 1,727 & 1,585 & 1,802 & 2,111 & 1,871 & 1,837 & 1,837 & 2,065 \\
\hline Acre & 1,339 & 1,360 & 1,819 & 1,769 & 1,932 & 2,239 & 2,043 & 2,079 & 2,091 & 2,408 \\
\hline Amazonas & 1,214 & 1,228 & 1,616 & 1,497 & 1,827 & 2,042 & 1,765 & 1,775 & 1,809 & 2,031 \\
\hline Roraima & 1,297 & 1,363 & 1,751 & 1,624 & 2,041 & 2,233 & 2,057 & 2,140 & 2,157 & 2,312 \\
\hline Pará & 1,341 & 1,356 & 1,931 & 1,877 & 1,536 & 2,288 & 2,062 & 2,118 & 2,061 & 2,130 \\
\hline Amapá & 1,363 & 1,382 & 1,949 & 1,873 & 2,017 & 2,182 & 1,995 & 2,137 & 2,017 & 2,182 \\
\hline Tocantins & 1,204 & 1,236 & 1,559 & 1,373 & 1,621 & 2,013 & 1,732 & 1,748 & 1,742 & 1,889 \\
\hline Região Nordeste & 1,143 & 1,145 & 1,534 & $\mathbf{1 , 4 3 5}$ & $\mathbf{1 , 6 7 8}$ & 1,904 & 1,714 & 1,755 & 1,749 & 1,898 \\
\hline Maranhão & 1,237 & 1,260 & 1,728 & 1,624 & 1,790 & 2,025 & 1,802 & 1,722 & 1,700 & 1,914 \\
\hline Piauí & 1,271 & 1,261 & 1,711 & 1,634 & 1,906 & 2,100 & 1,875 & 1,886 & 1,856 & 1,997 \\
\hline Ceará & 1,175 & 1,158 & 1,557 & 1,426 & 1,631 & 1,880 & 1,682 & 1,777 & 1,755 & 1,904 \\
\hline Rio Grande do Norte & 1,147 & 1,123 & 1,582 & 1,401 & 1,648 & 1,873 & 1,639 & 1,812 & 1,825 & 1,957 \\
\hline Paraíba & 1,124 & 1,103 & 1,479 & 1,400 & 1,644 & 1,905 & 1,738 & 1,765 & 1,684 & 1,849 \\
\hline Pernambuco & 1,069 & 1,062 & 1,414 & 1,332 & 1,563 & 1,819 & 1,577 & 1,656 & 1,649 & 1,860 \\
\hline Alagoas & 1,070 & 1,084 & 1,439 & 1,330 & 1,669 & 1,943 & 1,759 & 1,798 & 1,754 & 1,965 \\
\hline Sergipe & 1,133 & 1,148 & 1,525 & 1,424 & 1,740 & 2,044 & 1,889 & 1,837 & 1,764 & 1,932 \\
\hline Bahia & 1,186 & 1,213 & 1,598 & 1,491 & 1,657 & 1,813 & 1,635 & 1,677 & 1,704 & 1,877 \\
\hline Região Sudeste & $\mathbf{0 , 9 4 7}$ & 0,962 & 1,246 & 1,087 & 1,221 & 1,481 & 1,320 & 1,318 & 1,368 & 1,588 \\
\hline Minas Gerais & 1,053 & 1,061 & 1,435 & 1,333 & 1,536 & 1,875 & 1,642 & 1,592 & 1,621 & 1,847 \\
\hline Espírito Santo & 1,155 & 1,111 & 1,379 & 1,235 & 1,530 & 1,965 & 1,790 & 1,761 & 1,835 & 2,035 \\
\hline Rio de Janeiro & 1,035 & 1,065 & 1,404 & 1,281 & 1,534 & 1,834 & 1,641 & 1,648 & 1,683 & 1,872 \\
\hline São Paulo & 0,874 & 0,893 & 1,132 & 0,972 & 1,177 & 1,412 & 1,274 & 1,279 & 1,336 & 1,524 \\
\hline Região Sul & 1,070 & 1,095 & 1,412 & 1,302 & $\mathbf{1 , 5 1 8}$ & 1,793 & 1,546 & 1,530 & 1,576 & 1,762 \\
\hline Paraná & 0,918 & 0,950 & 1,234 & 1,156 & 1,377 & 1,641 & 1,450 & 1,407 & 1,457 & 1,628 \\
\hline Santa Catarina & 1,133 & 1,150 & 1,485 & 1,375 & 1,610 & 1,804 & 1,701 & 1,691 & 1,724 & 1,960 \\
\hline Rio Grande do Sul & 1,191 & 1,223 & 1,572 & 1,425 & 1,794 & 2,148 & 1,743 & 1,759 & 1,784 & 2,010 \\
\hline Região Centro-Oeste & 1,092 & 1,121 & 1,446 & 1,373 & 1,565 & 1,819 & 1,567 & 1,638 & 1,636 & 1,783 \\
\hline Mato Grosso do Sul & 1,144 & 1,114 & 1,474 & 1,435 & 1,633 & 1,915 & 1,699 & 1,708 & 1,697 & 1,825 \\
\hline Mato Grosso & 1,079 & 1,165 & 1,559 & 1,507 & 1,715 & 1,979 & 1,456 & 1,371 & 1,389 & 1,708 \\
\hline Goiás & 1,028 & 1,060 & 1,368 & 1,255 & 1,395 & 1,630 & 1,421 & 1,505 & 1,542 & 1,600 \\
\hline Distrito Federal & 1,174 & 1,218 & 1,517 & 1,481 & 1,665 & 1,905 & 1,695 & 1,829 & 1,842 & 2,015 \\
\hline
\end{tabular}

Nota: Preços em valores correntes.

${ }^{1}$ Preços médios de 2001 calculados com base nos preços entre julho e dezembro.

Fonte: ANP/CDC (Levantamento de Preços e de Margens de Comercialização de Combustíveis), 2011. 
No Estado de São Paulo, no ano de 2001, o etanol que custava ao consumidor final em média $\mathrm{R}$ \$ 0,874 atingiu sua elevação média no ano de 2010 em $\mathrm{R}$ \$ 1,524, correspondente a 74,4\% de aumento em 10 anos. Em outra análise, o Estado de Roraima, o mais distante da maior região produtora de etanol, Centro-Sul, o preço variou de R \$ 1,297 em 2001 para R 2,312 em 2010, um crescimento na ordem de 78,3\%. Nota-se o quanto o preço tanto de São Paulo quanto de Roraima, apresentou tamanha variação nos preços de etanol hidratado, devendo-se considerar que há diferenças relativas à frota de veículos, à tributação, aos produtores, à capacidade de armazenamento e à logística. Comparando-se os preços apenas no ano de 2010 entre esses Estados, observa-se que Roraima é 51,7\% mais caro. Considerando-se os mesmos Estados analisados, a Tabela 13, a seguir, traz dados referentes à gasolina C. 
Tabela 13 - Preço médio da gasolina C ao consumidor, segundo Grandes Regiões e Unidades da Federação: 2001-2010

\begin{tabular}{|c|c|c|c|c|c|c|c|c|c|c|}
\hline Regiões e U.F. & $2001^{1}$ & 2002 & 2003 & 2004 & 2005 & 2006 & 2007 & 2008 & 2009 & 2010 \\
\hline Brasil & 1,741 & 1,735 & 2,072 & 2,082 & 2,312 & 2,541 & 2,504 & 2,501 & 2,502 & 2,567 \\
\hline Região Norte & 1,913 & 1,856 & 2,212 & 2,259 & 2,553 & 2,691 & 2,655 & 2,708 & 2,733 & 2,743 \\
\hline Rondônia & 1,930 & 1,990 & 2,360 & 2,368 & 2,553 & 2,678 & 2,618 & 2,662 & 2,631 & 2,760 \\
\hline Acre & 1,946 & 1,950 & 2,438 & 2,433 & 2,649 & 2,919 & 2,893 & 2,938 & 2,929 & 2,985 \\
\hline Amazonas & 1,890 & 1,753 & 2,015 & 2,112 & 2,574 & 2,549 & 2,452 & 2,426 & 2,556 & 2,613 \\
\hline Roraima & 1,825 & 1,694 & 2,015 & 2,083 & 2,601 & 2,852 & 2,622 & 2,683 & 2,691 & 2,833 \\
\hline Pará & 1,945 & 1,881 & 2,240 & 2,299 & 2,429 & 2,589 & 2,556 & 2,719 & 2,738 & 2,765 \\
\hline Amapá & 1,900 & 1,874 & 2,296 & 2,238 & 2,446 & 2,553 & 2,397 & 2,592 & 2,700 & 2,849 \\
\hline Tocantins & 1,905 & 1,815 & 2,225 & 2,202 & 2,525 & 2,754 & 2,733 & 2,747 & 2,746 & 2,824 \\
\hline Região Nordeste & 1,769 & 1,750 & 2,096 & 2,133 & 2,409 & 2,670 & 2,632 & 2,629 & 2,622 & 2,636 \\
\hline Maranhão & 1,820 & 1,769 & 2,108 & 2,065 & 2,358 & 2,728 & 2,720 & 2,633 & 2,583 & 2,583 \\
\hline Piauí & 1,870 & 1,706 & 2,139 & 2,175 & 2,409 & 2,479 & 2,533 & 2,588 & 2,549 & 2,518 \\
\hline Ceará & 1,780 & 1,724 & 2,074 & 2,202 & 2,446 & 2,687 & 2,586 & 2,540 & 2,501 & 2,633 \\
\hline Rio Grande do Norte & 1,742 & 1,708 & 2,082 & 2,097 & 2,355 & 2,632 & 2,541 & 2,586 & 2,586 & 2,675 \\
\hline Paraíba & 1,788 & 1,760 & 2,094 & 2,063 & 2,358 & 2,608 & 2,535 & 2,440 & 2,399 & 2,446 \\
\hline Pernambuco & 1,744 & 1,723 & 2,051 & 2,101 & 2,380 & 2,641 & 2,596 & 2,586 & 2,565 & 2,616 \\
\hline Alagoas & 1,734 & 1,793 & 2,204 & 2,204 & 2,596 & 2,817 & 2,824 & 2,773 & 2,696 & 2,726 \\
\hline Sergipe & 1,692 & 1,651 & 2,042 & 2,047 & 2,337 & 2,542 & 2,508 & 2,513 & 2,547 & 2,607 \\
\hline Bahia & 1,774 & 1,814 & 2,134 & 2,143 & 2,345 & 2,610 & 2,587 & 2,594 & 2,615 & 2,714 \\
\hline Região Sudeste & 1,706 & 1,704 & 2,023 & 2,023 & 2,259 & 2,483 & 2,452 & 2,446 & 2,445 & 2,513 \\
\hline Minas Gerais & 1,721 & 1,691 & 2,028 & 2,040 & 2,209 & 2,412 & 2,393 & 2,381 & 2,378 & 2,516 \\
\hline Espírito Santo & 1,743 & 1,759 & 2,123 & 2,113 & 2,372 & 2,612 & 2,610 & 2,618 & 2,622 & 2,686 \\
\hline Rio de Janeiro & 1,738 & 1,713 & 2,120 & 2,095 & 2,329 & 2,525 & 2,494 & 2,516 & 2,544 & $2,64 \mathrm{C}$ \\
\hline São Paulo & 1,690 & 1,703 & 1,989 & 1,986 & 2,237 & 2,418 & 2,396 & 2,387 & 2,384 & 2,463 \\
\hline Região Sul & 1,759 & 1,777 & 2,157 & 2,163 & 2,459 & 2,641 & 2,539 & 2,527 & 2,506 & 2,571 \\
\hline Paraná & 1,714 & 1,713 & 2,054 & 2,063 & 2,282 & 2,467 & 2,416 & 2,395 & 2,445 & 2,530 \\
\hline Santa Catarina & 1,790 & 1,791 & 2,193 & 2,173 & 2,443 & 2,562 & 2,541 & 2,537 & 2,536 & 2,578 \\
\hline Rio Grande do Sul & 1,784 & 1,832 & 2,240 & 2,231 & 2,570 & 2,697 & 2,528 & 2,534 & 2,539 & 2,602 \\
\hline Região Centro-Oeste & 1,758 & 1,748 & 2,122 & 2,180 & 2,431 & 2,655 & 2,626 & 2,598 & 2,644 & 2,658 \\
\hline Mato Grosso do Sul & 1,807 & 1,767 & 2,149 & 2,245 & 2,570 & 2,737 & 2,684 & 2,673 & 2,620 & 2,649 \\
\hline Mato Grosso & 1,844 & 1,886 & 2,367 & 2,453 & 2,749 & 2,941 & 2,881 & 2,712 & 2,689 & 2,772 \\
\hline Goiás & 1,719 & 1,722 & 2,059 & 2,075 & 2,341 & 2,547 & 2,494 & 2,477 & 2,576 & 2,555 \\
\hline Distrito Federal & 1,713 & 1,713 & 2,096 & 2,091 & 2,364 & 2,596 & 2,572 & 2,554 & 2,680 & 2,714 \\
\hline
\end{tabular}

Nota: Preços em valores correntes.

1Preços médios de 2001 calculados com base nos preços entre julho e dezembro.

Fonte: ANP/CDC (Levantamento de Preços e de Margens de Comercialização de Combustíveis), 2011. 
No Estado de São Paulo, no ano de 2001, a gasolina C custava ao consumidor final em média $\mathrm{R} \$ 1,690$, e atingiu sua elevação média no ano de 2010 para $\mathrm{R} \$ 2,463$, o que corresponde a 45,7\% de aumento em 10 anos. Já para o Estado de Roraima, o preço variou de $\mathrm{R} \$ 1,825$, passando para o ano de 2010 a uma média de $\mathrm{R} \$ 2,833$, um crescimento na ordem de 55,2\%. A diferença de um Estado para outro, considerando apenas o ano de 2010, foi de 15,1\%. Nota-se que, na gasolina $\mathrm{C}$, a variação é bem inferior ao que houve na variação dos preços do etanol hidratado. E, em hipótese, tem-se que a capacidade de armazenamento e a logística não sejam as principais variáveis responsáveis pela oscilação nos preços, uma vez que a tancagem usada para armazenar gasolina é a mesma para o etanol hidratado. Daí a importância de se correlacionar as variáveis: frota, produção, tributos entre outros, sob uma análise mais quantitativa para investigar sua relação na constituição dos preços praticados na revenda, sendo este possível de se observar por macrorregiões no capítulo seguinte.

Em decorrência da variabilidade dos preços do etanol hidratado entre as regiões do país, coube uma breve investigação do seu respectivo comportamento com base nos dados dos preços médios fornecidos pela ANP desde o ano de 2001 até o ano de 2010. Ou seja, averiguou-se a existência de diferença entre o preço da gasolina $\mathrm{C}$ e do etanol hidratado, adotando-se como método de análise a relação preço entre os dois combustíveis, utilizando a seguinte abordagem:

Relação entre Preços $=\frac{\text { Preço do etanol }}{\text { Preço da gasolina }}$

O resultado dessa relação mostra o quanto o preço do etanol representa do preço da gasolina C. Considerando o fator desempenho médio dos veículos, quando o etanol representar até 0,7 (70\%) do preço da gasolina $\mathrm{C}$, o etanol é mais viável ou vantajoso. Em cenários em que o etanol representa mais de $0,7(70 \%)$ do preço da gasolina $\mathrm{C}$, ele passa a ser mais inviável. Para ilustrar as relações entre os preços do etanol hidratado e da gasolina $\mathrm{C}$, construíram-se no período de 2001 a 2010 os Gráficos 5 e 6, sendo que o primeiro traz um panorama geral do etanol no país, e o segundo estratificou-se por macrorregiões, em que é destacado o limitador 0,7 , representado em forma de reta para indicar a respectiva vantagem do etanol hidratado em relação à gasolina $\mathrm{C}$. 


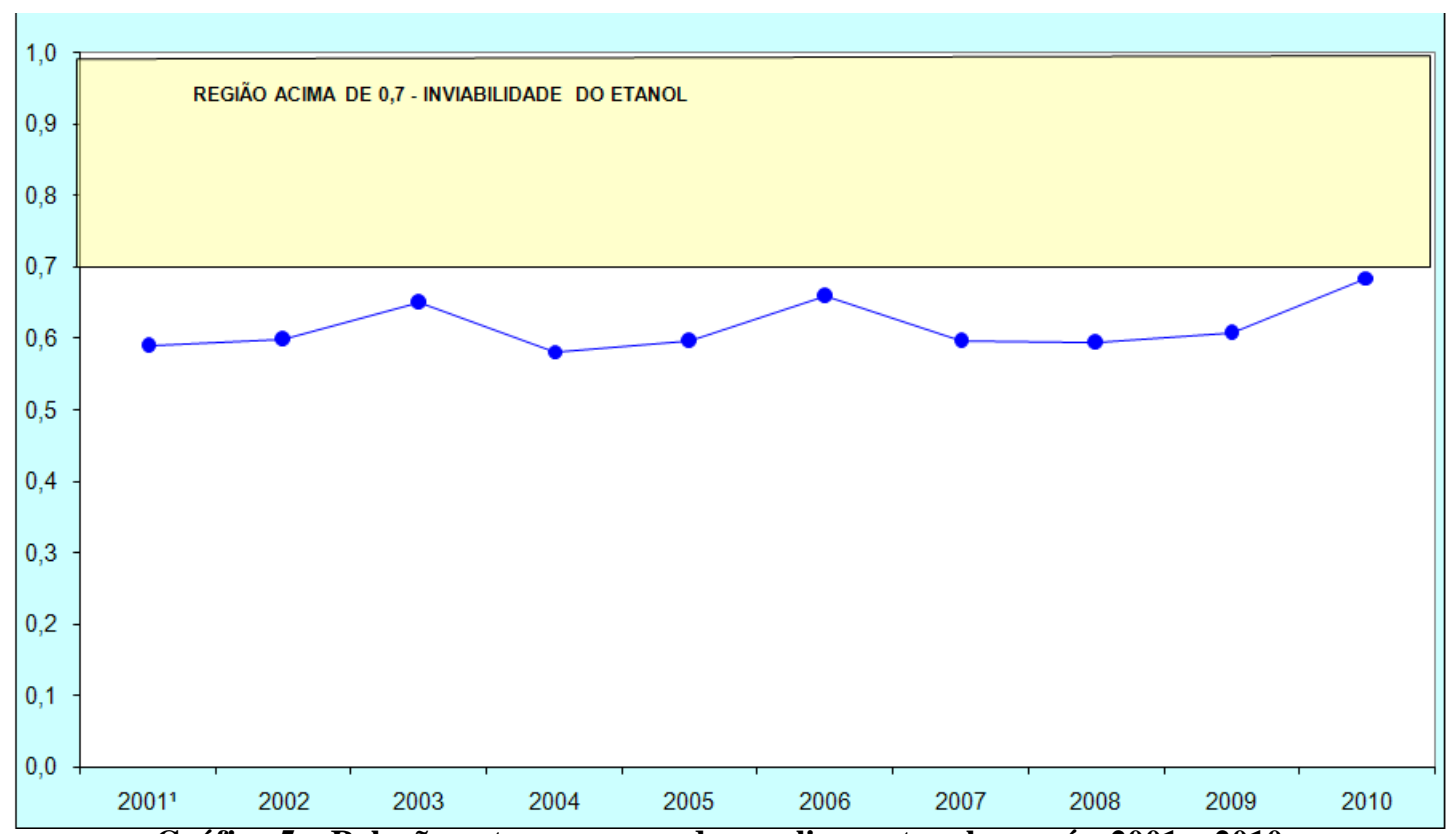

Gráfico 5 - Relação entre os preços de gasolina e etanol no país: 2001 a 2010

Fonte: desenvolvido pelo autor.

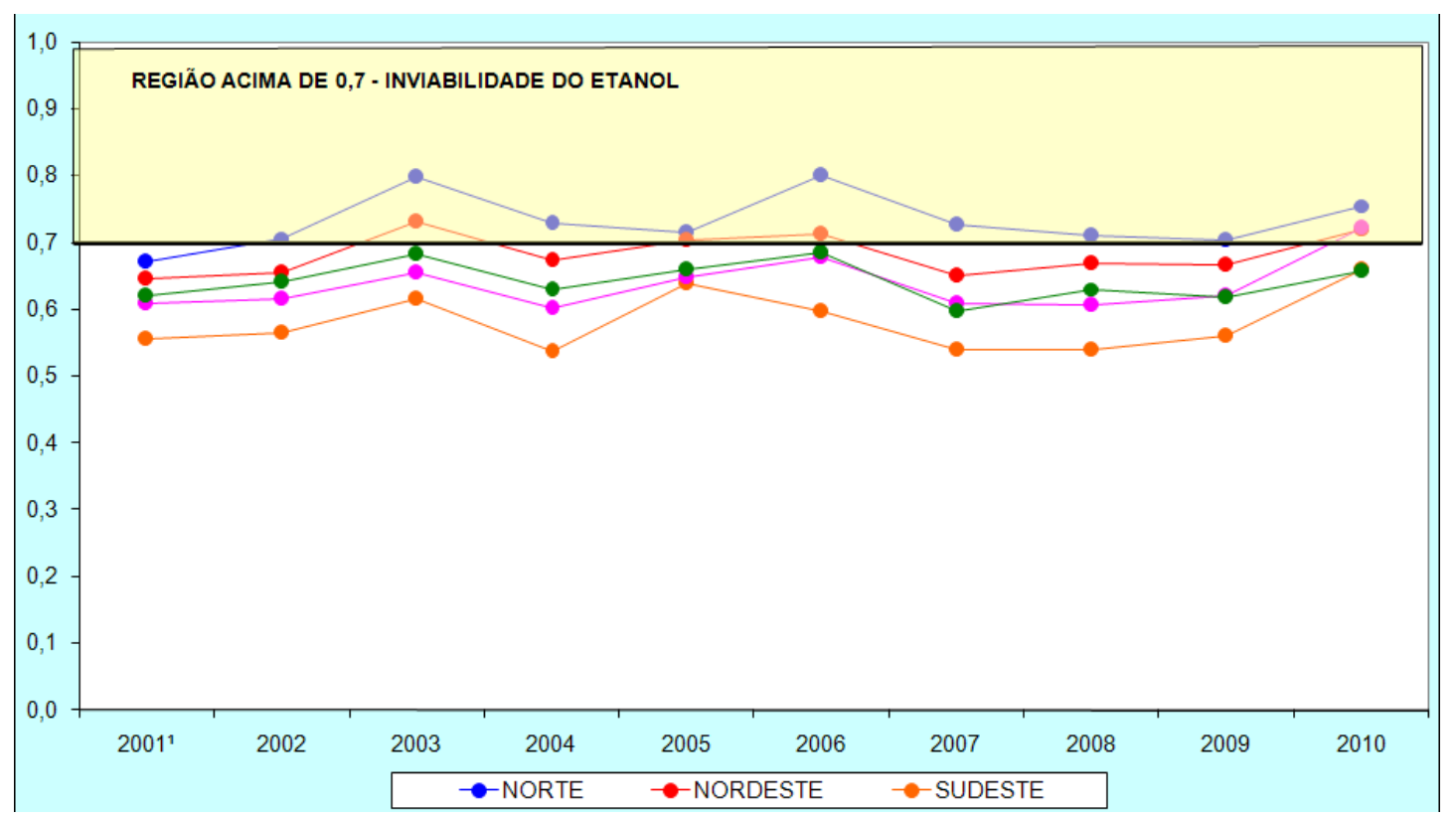

Gráfico 6 - Relação entre os preços de gasolina e etanol nas macrorregiões: 2001 a 2010 Fonte: desenvolvido pelo autor.

O Gráfico 5 revelou que o etanol hidratado, para o período de 2001 a 2010, demonstrou ser vantajoso para o país. Mas por se tratar de uma análise comportamental da média relacional dos preços, tal vantagem mais adiante será melhor investigada com a análise da variância. Observa-se que, no ano de 2010 a vantagem se apresentou próxima à margem limitadora, isso implica que a média dos preços nesse período tiveram forte variabilidade. Ademais, essa variação nos preços motiva investigar se a produção, tributos, armazenagem, preço da gasolina, custos, frota, entre outros, têm exercido sua relação ao constituí-lo e, em seguida, no sentido de majorar preços ao consumidor final, podendo este ser constatado quantitativamente 
no capítulo seguinte por meio da regressão linear múltipla. Em paralelo, tem-se o Gráfico 6, no qual fica evidente que apenas na região norte do país predominou a vantagem no abastecimento por gasolina $\mathrm{C}$, acompanhada por fortes oscilações, durante o período em análise, pela região nordeste. Em contrapartida, a região sudeste apresentou-se a mais suscetível na vantagem de se abastecer com o etanol hidratado. A Figura 13, em sua forma mais estratificada de análise, ilustra as vantagens de se abastecer com etanol hidratado para os Estados, considerando-se a média dos preços de cada combustível no período de 2001 a 2010.

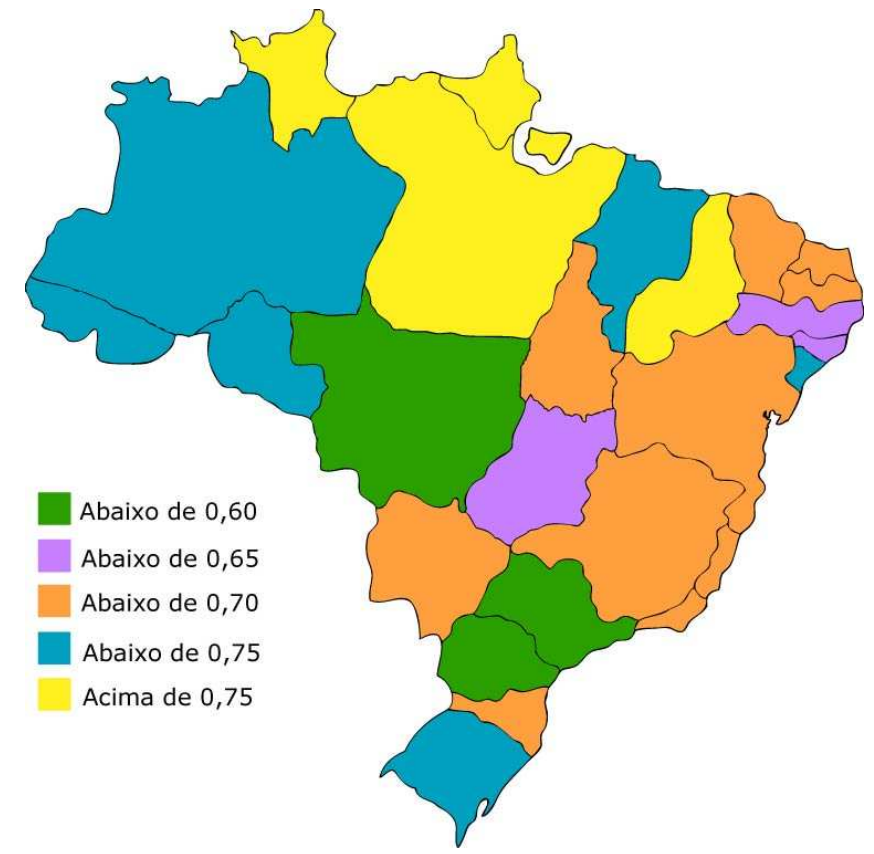

Figura 13 - Relação entre os preços de gasolina e etanol por Estado Fonte: desenvolvido pelo autor.

Observa-se, na figura anterior, que os Estados do Paraná, São Paulo e Mato Grosso, em média, dentre os anos de 2001 a 2010, apresentaram vantagem no abastecimento pelo etanol hidratado; ao contrário do que ocorreu na maior parte dos Estados brasileiros, uma vez que 20 Estados não configuram ser plenamente vantajoso abastecer por etanol hidratado. Destaca-se que outros 3 Estados, Goiás, Pernambuco e Alagoas, demonstraram em média ser vantajoso o uso do etanol hidratado, de tal forma que, na maior parte dos Estados mais produtores do país, demonstrou-se vantajoso o abastecimento com etanol hidratado: Paraná, São Paulo, Mato Grosso e Goiás; e, outros, que também pertencem à região de alta produtividade, como Minas Gerais, Espírito Santo e Mato Grosso do Sul, não apresentaram ser vantagem em se abastecer com etanol hidratado. Com base nesses dados, compreende-se que, possivelmente, a variável produção não se associa significativamente em sua relação com a formação dos preços, e tal percepção será melhor corroborada no capítulo seguinte, momento em que é apresentada a variável produção por Estado. 
Tomando-se como referência os estudos do BNDES (2008), a faixa de variação de preços ao produtor de etanol decorre do valor dos custos de produção e da oportunidade dos produtos alternativos da matéria-prima utilizada pela agroindústria (cana-de-açúcar), sendo que o limite superior depende efetivamente das condições de mercado, uma vez que há a ausência de mecanismos de intervenção. Desse modo, considerar o fato de o Estado ser fortemente produtor não implica diretamente que os preços sejam menores em relação aos outros, Isso porque há outras variáveis a serem observadas, como, por exemplo, os tributos e a frota etanol e flex. Fica evidente que há complexidade na formação de preços, e se agrava ao considerar os diversos fins de produção a partir da cana-de-açúcar, produtos intermediários e finais, que são variados (etanol anidro e hidratado, açúcar, energia elétrica e mais recentemente o eteno e farneceno). Portanto, a complexidade na determinação dos preços se dá, pois o ordenamento da escolha de produção, considerando o livre mercado, dependerá de seus preços relativos.

Conforme os estudos apontados pelo BNDES (2008), uma tributação diferenciada proporciona o estímulo suficiente para que as incertezas e percepções de risco sejam superadas, dinamizando o setor, inclusive o de distribuição dos combustíveis que carece de avanços ao ponto de se tornarem agentes ativos do processo de motivação dos consumidores para a adoção do etanol. Observa-se, portanto, a necessidade de um marco tributário específico para o etanol, respeitando as necessidades de equilíbrio fiscal e abastecimento do mercado interno. E reconhecendo que se trata de um produto com possibilidades de outros usos, depara-se com a necessidade em sua precificação de uma recomposição na aplicação tributária, uma vez que esta pode ter forte correlação com os preços, como poderá ser visto mais adiante. Todavia, o impeditivo de se obter um único tributo entre todas as unidades da Federação do país e se optar pela substituição tributária explica-se pelo fato de determinado Estado deixar de arrecadar mais, por conta da frota de veículos que relativamente pode ser baixa, causando desequilíbrio do orçamento público.

Essa característica também foi observada nos estudos do BNDES (2008), que, mesmo obedecendo aos instrumentos efetivos de política energética, vem por sua vez dar consistência à necessidade de desenvolvimento do mercado do etanol, uma vez que a frota de veículos flexíveis vem aumentando significativamente. E se no aspecto tributário há complicador por razões de frota de veículos e orçamento público, é necessário então, em curto prazo, equacionalizar os custos quanto aos ganhos de produtividade na matéria-prima e outros como: 
melhoria logística e de armazenagem e instituição de normas e regulamentos de incentivo às bases secundárias, que hoje se encontram concentradas na região Centro-Sul.

Dessa forma, conforme já mencionado, o preço do etanol também limita o aumento do preço da gasolina, já que os consumidores que, eventualmente, usam gasolina deixarão de fazê-lo caso o etanol lhes pareça mais atrativo. Esse efeito substituição é exercido pelo consumidor por ele considerar os custos finais na utilização dos combustíveis, que são, por sua vez, uma consequência relativa dentre as diferenças de consumo por quilômetro percorrido, e tem constituído um efeito equacionalizador dos preços dos combustíveis no Brasil, mesmo em tempos de altos preços do barril de petróleo.

É oportuno destacar que, na relação comercial entre a usina e as bases distribuidoras do etanol, o contrato adotado no Centro-Sul do país estabelece como parâmetro de padronização de preços do etanol tanto anidro quanto hidratado o indicador Esalq, por meio do Cepea (Centro de Estudos Avançados em Economia Aplicada) da Escola Superior de Agricultura "Luiz de Queiroz" - Esalq. Este instituto calcula e divulga um indicador base de preço para o hidratado e para o anidro, oferecendo dois indicadores por produto para região do Estado de São Paulo: um semanal e outro mensal. Estes indicadores referem-se à ponderação das consultas feitas nestas regiões sobre os preços referentes aos negócios efetivamente concluídos entre usinas e distribuidoras, no mercado spot. Assim sendo, trata-se de preço base ou de referência, e não um indicador que visa estabelecer o preço no mercado.

Segundo Dolnikoff (2008, p. 99), há possibilidades de se estabelecer contrato entre usinas e distribuidoras tomando-se como base de negociação o indicador Esalq do momento, o qual possui uma vigência de 1 a 2 anos, com cláusulas que permitem renovação, sendo atreladas ao ano-safra ou ao ano civil; podendo até mesmo estipular um volume a ser comercializado mensalmente entre as partes. Este volume mensal deve ter suas retiradas do etanol na usina produtora acordadas de alguma forma, sendo as mais comuns as retiradas semanais ou quinzenais. Apesar do estabelecimento de um cronograma de retiradas, geralmente existe algum mecanismo contratual, alguma cláusula, que permite flexibilizar as datas dentro do mês, para que, no mês em questão, os agentes tenham a possibilidade de ajustar as datas às suas necessidades do momento.

Percebe-se, desse modo, que a preocupação quanto aos prazos de fornecimento de etanol na 
negociação entre usina e distribuidora são relevantes e, consequentemente, é possível constatar que o diferencial logístico de cada usina impacta diretamente no resultado das negociações de desconto com as distribuidoras. Contudo, o diferencial logístico é fator relevante na constituição do preço num contrato estabelecido entre usina e distribuidora, em que o preço é sempre calculado ex-post ao momento da contratação. Em contrapartida, o Sindicato do Comércio Varejista de Derivados de Petróleo do Estado de São Paulo Sincopetro, arbitra que os preços (desconsiderando margens de lucro) são formados basicamente pelos custos de aquisição da matéria-prima (petróleo e/ou etanol), impostos e custos de transporte, tal como pode ser observado na Tabela 14, que ilustra a composição de custos nas distribuidoras de combustíveis do Estado de São Paulo.

Tabela 14 - Composição de custos do litro de combustível nas distribuidoras do Estado de São Paulo

\begin{tabular}{|c|c|c|c|}
\hline Gasolina & $\mathbf{R} \$$ & Etanol & $\mathbf{R} \$$ \\
\hline Preço de compra do litro de gasolina A na & 1,10440 & Preço de compra do litro de etanol & 0,67730 \\
\hline CIDE & 0,18000 & & \\
\hline PIS & 0,04658 & PIS & 0,01239 \\
\hline COFINS & 0,21502 & COFINS & 0,05721 \\
\hline ICMS & 0,80572 & ICMS & 0,12731 \\
\hline FRETE (etanol anidro) & 0,04500 & FRETE (etanol hidratado) & 0,04500 \\
\hline (a) anidro com frete & 0,84469 & & \\
\hline (b) gasolina A com impostos & 2,35172 & & \\
\hline TOTAL $(25 \% a+75 \% b)$ & 1,97496 & TOTAL & 0,91921 \\
\hline
\end{tabular}

Fonte: Sincopetro (2010).

De acordo com a Tabela 14, é possível perceber que, para a distribuidora, o custo do frete na aquisição de etanol hidratado corresponde a 4,8\% do custo total, e os tributos representam 21,4\%, para o Estado de São Paulo, o mais significativo na composição dos custos, já incluso o ICMS de 12\%. Para a gasolina, o percentual, respectivo à frete e a tributos, corresponde a $2,3 \%$ e a $63,1 \%$. O tributo é ainda mais oneroso para a gasolina, pois, na formação de preço, destacam-se a Contribuição de Intervenção sobre o Domínio Econômico - CIDE, constituída pela Lei n ${ }^{\circ} 10.336$ de 19 de dezembro de 2001, a Cofins e o ICMS. A contribuição da CIDE, que incide sobre o combustível gasolina $\mathrm{A}$ e $\mathrm{C}$, tem por finalidade realizar projetos que financiam programas de infraestrutura de transportes, inclusive de construção de tancagem para armazenar etanol.

Apesar de haver tributo, CIDE, específico para investimentos em estrutura no mercado de combustíveis, Xavier (2008, p. 43) destaca que na safra de 2002/2003, após a 
desregulamentação, visando estimular a produção de etanol e a formação de estoques suficientes para assegurar a regularidade do abastecimento no período da entressafra; os investimentos estatais nessa modalidade não foram identificados. Os investimentos que existem são tomados pelas usinas junto ao BNDES e o governo em si não opera construindo, por exemplo, tanques de armazenagem de combustível. Em visita à ANP em setembro de 2010, ao indagar sobre as possibilidades de problemas na oferta de etanol por conta da pressão da demanda e da falta de estrutura de tancagem, pôde-se constatar a possibilidade de ser estudado um estoque regulador de etanol no país, caso o combustível fique sob ameaça de faltar ao mercado consumidor, uma vez que programas de investimentos não estejam atraindo os produtores.

Ainda sob o ponto de vista de custos, segundo os estudos do BNDES (2008), considerando todos os fatores - matéria-prima, operação, manutenção e investimento, o etanol de cana-deaçúcar situa-se entre US\$ 0,353 e US\$ 0,406 por litro, valores correspondentes ao petróleo entre US\$ 50 e US\$ 57 o barril (equivalente a 159 litros, o que corresponde a US\$ 0,314 e US\$ 0,358 em litros). Nota-se, portanto, que o custo de produção de etanol ainda é muito alto.

Segundo os estudos realizados no Sindicom (2010), a formação de preços do etanol com base nos custos e margem auferida pode ser observada no Quadro 1, envolvendo cada agente presente na cadeia do etanol (produtor, distribuidor e revenda). No entanto, é válido ressaltar que o Sindicom tem significância relativa nos dados levantados, por representar, em nível nacional, as principais companhias distribuidoras de combustíveis e de lubrificantes: AirBP, Ale, Castrol, Chevron, Cosan, Ipiranga, Petrobras Distribuidora, Petronas Lubrificantes, Repsol, Shell e Total. Suas associadas representam mais de $80 \%$ do volume de distribuição de combustíveis e lubrificantes no Brasil, sendo que no setor de etanol sua representatividade é de $60 \%$ do total comercializado no mercado. A Sindicom revelou números na composição de custos e margem na cadeia distributiva do etanol no país, em que as Unidades de Federação destacadas no Quadro 1 representam 90\% do consumo nacional. 
Quadro 1 - Formação de Preços do Etanol no país

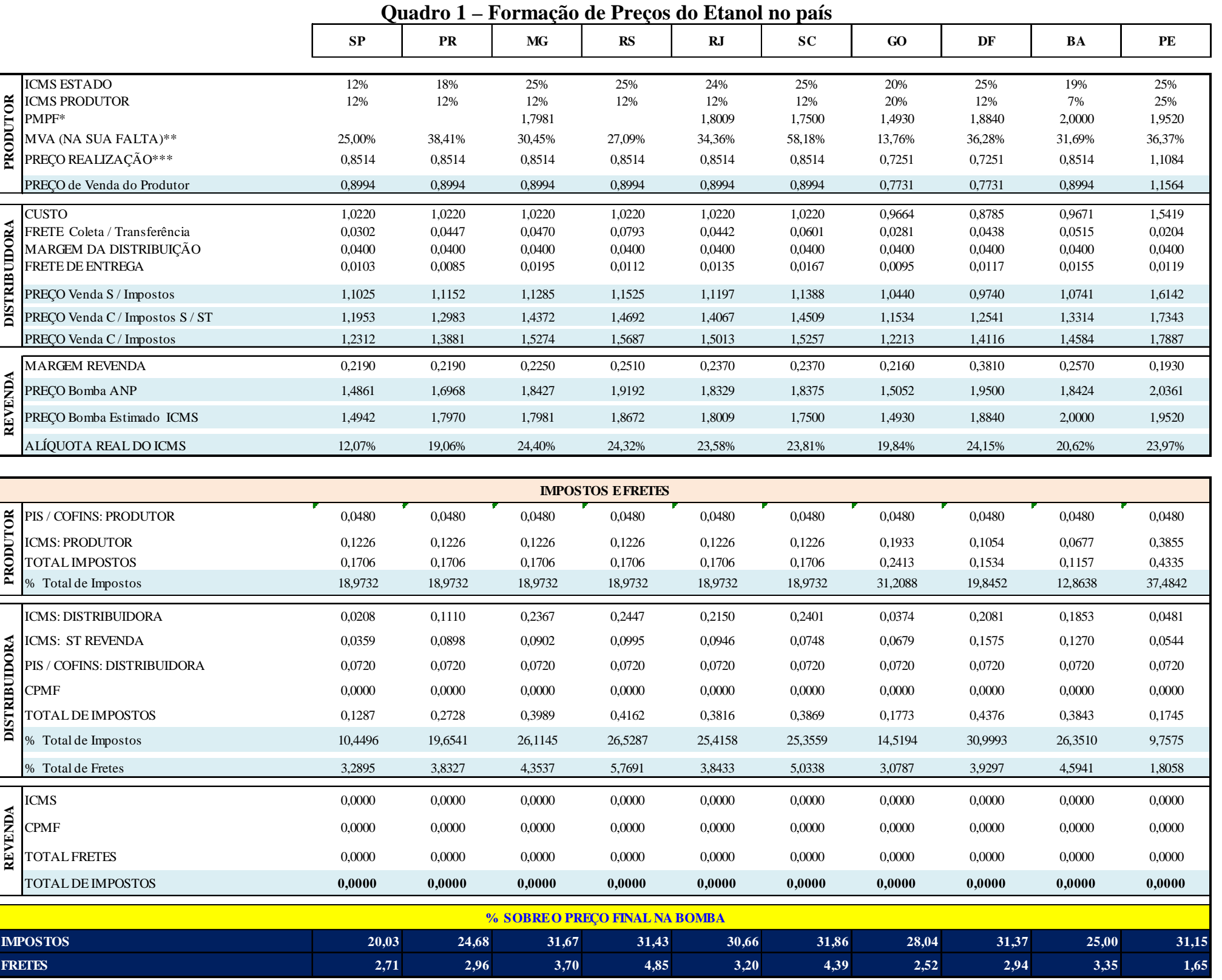

*Preço Médio Ponderado ao Consumidor Final;** Margem de Valor Agregado, serve como base para cálculo do ICMS ao produtor; *** Custos + margens de lucro; **** Recolhe somente quando for produção de etanol anidro destinado como combustível carburante a ser misturado na gasolina A. Base setembro de 2010.

Fonte: Sindicom (2010), adaptado pelo autor. 
O Quadro 1 é significativo na análise da presente pesquisa no sentido de validar se tributos e/ou fretes são de fato significativos e em que proporção atuam na diferenciação dos preços do etanol no mercado brasileiro. Observa-se que o Estado de São Paulo apresenta o menor percentual tributário e o segundo menor custo com fretes. É interessante observar também que o Estado de Pernambuco apresenta o menor custo com fretes, porém possui uma carga tributária expressiva de $25 \%$ em ICMS ao produtor, e o maior custo formado na base distribuidora, o que onera o preço final na bomba, sendo o Estado com o segundo maior preço praticado ao consumidor final, ao passo que o primeiro é o Estado da Bahia. Vale destacar que o período analisado é de apenas o mês de setembro de 2010, e que, embora seja uma amostra pequena, é capaz de demonstrar em sua composição o comportamento dos tributos, fretes, custos e margens dentre os atores do setor. Isso porque, conforme visto anteriormente, o Estado de Pernambuco, entre o período de 2001 a 2010, apresentou-se em sua média vantagem no abastecimento do etanol hidratado. Nota-se, dessa forma, que os tributos têm sido o principal componente que onera o preço final ao consumidor de etanol.

Outro aspecto a considerar é que, para evitar fraudes, a Sindicom tem adotado desde 2001 o Preço Médio Ponderado ao Consumidor Final (PMPF), homologado em Ato COTEPE, atualmente com o convênio junto ao Conselho Nacional de Política Fazendária (Confaz) na finalidade de agregar esforços fiscais ao ICMS, decorrente do Decreto Lei no 110/07 (cláusula $\left.9^{a}\right)$. Seu objetivo visa facilitar a fiscalização e o repasse do ICMS entre Estados, sendo este o principal mecanismo para reduzir as fraudes e a sonegação na comercialização dos combustíveis automotivos, tendo a lei como principal dispositivo para assegurar a arrecadação do Estado, cujo dispositivo diz:

Cláusula nona: ficam os Estados e o Distrito Federal autorizados a adotar, nas operações promovidas pelo sujeito passivo por substituição tributária, relativamente às saídas subseqüentes com combustíveis líquidos e gasosos derivados ou não de petróleo, a margem de valor agregado obtida mediante aplicação da seguinte fórmula, a cada operação:

MVA $=\{[$ PMPF x $(1$ - ALIQ $)] /[($ VFI + FSE $) \times(1-$ IM) $)-1\} \times 100$, considerando-se:

MVA: margem de valor agregado expressa em percentual;

PMPF: preço médio ponderado a consumidor final do combustível considerado, com ICMS incluso, praticado em cada unidade federada;

ALIQ: percentual correspondente à alíquota efetiva aplicável à operação praticada pelo sujeito passivo por substituição tributária, salvo na operação interestadual com produto contemplado com a não incidência prevista no art. $155, \S 2^{\circ}, \mathrm{X}$, "b", da Constituição Federal, hipótese em que assumirá o valor zero;

VFI: valor da aquisição pelo sujeito passivo por substituição tributária, sem ICMS;

FSE: valor constituído pela soma do frete sem ICMS, seguro, tributos, exceto o ICMS relativo à operação própria, contribuições e demais encargos transferíveis ou cobrados do destinatário;

IM: índice de mistura do etanol anidro combustível na gasolina C, ou do biodiesel B100 na mistura com o óleo diesel, salvo quando se tratar de outro combustível, hipótese em que assumirá o valor zero. (SINDICOM, 2010). 
Portanto, tem-se o PMPF a ser utilizado para determinação da margem de valor agregado divulgado mediante Ato COTEPE publicado no Diário Oficial da União, e de todos os Estados do país, sob a finalidade de evitar a sonegação fiscal. No entanto, somente 21 praticam o PMPF e apenas três Estados praticam o MVA, uma vez que os valores no cálculo do MVA podem ser passíveis de subfaturamento. Contudo, tem-se a seguinte estrutura na formação de preço em toda a cadeia do etanol, segundo ANP, conforme demonstra o Quadro 2.

Quadro 2 - Estrutura de preço do etanol hidratado

Composição do preço do etanol hidratado no produtor

A. Preço de realização (1)

B. Contribuição de Intervenção no Domínio Econômico = Cide (3)

C. PIS/Pasep e Cofins (4)

D. Preço de faturamento sem ICMS $D=A+B+C$

E. ICMS produtor $\mathrm{E}=[(\mathrm{D} /(1-\mathrm{ICMS} \%)]-\mathrm{D}$ (5)

F. Preço de faturamento do produtor com ICMS $\mathrm{F}=\mathrm{D}+\mathrm{E}$

Composição do preço a partir da distribuidora

G. Frete até a base de distribuição (2)

$\mathrm{H}$. Custo de aquisição da distribuidora $\mathrm{H}=\mathrm{F}+\mathrm{G}$

I. Frete da base de distribuição até o posto revendedor

J. Margem da distribuidora

K. PIS/Pasep e Cofins (4)

L. Preço da distribuidora sem ICMS $\mathrm{L}=\mathrm{H}+\mathrm{I}+\mathrm{J}+\mathrm{K}-\mathrm{E}$

M. ICMS da distribuidora $\mathrm{M}=[(\mathrm{L} /(1-\mathrm{ICMS} \%)]-\mathrm{L}-\mathrm{E}$ (5)

N. Preço da distribuidora com ICMS sem Substituição Tributária da revenda $\mathrm{N}=\mathrm{M}+\mathrm{L}+$

O. (i) ICMS da Substituição Tributária da revenda (com PMPF) O = (PMPFxICMS\%)-E-M(6) ou

(ii) ICMS da Substituição Tributária da revenda (na ausência do PMPF) $\mathrm{O}=\% \operatorname{MVAx}(\mathrm{E}+\mathrm{M})(7)$

P. Preço de faturamento da distribuidora $\mathrm{P}=\mathrm{N}+\mathrm{O}$ (i) ou $\mathrm{P}=\mathrm{N}+\mathrm{O}$

Composição do preço final de venda do etanol hidratado no posto revendedor

$\mathrm{Q}$. Preço de aquisição da distribuidora $\mathrm{Q}=\mathrm{P}$

R. Margem da revenda

S. Preço bomba do etanol hidratado combustível $S=Q+R$

\section{Observações:}

(1) Preço FOB (sem fretes e tributos)

(2) Frete até a base de distribuição (quando cobrados separadamente)

(3) Lei $\mathrm{n}^{\mathrm{o}} 10.336$, de 12/12/01 e suas alterações, combinada com o Decreto $\mathrm{n}^{\circ} 5.060$, de 30/04/04 e suas alterações.

(4) Lei $\mathrm{n}^{\circ} 11.727$, de 23/06/08 e suas alterações combinada com o Decreto $\mathrm{n}^{\circ} 6.573$, de 19/09/08 e suas alterações

(para os contribuintes que optaram pela alíquota específica)

(5) Alíquotas estabelecidas pelos governos estaduais (com reduções das bases de cálculo, se houver) e acrescidas do "Fundo de Pobreza" (se houver). produtor

Algumas legislações estaduais diferem o ICMS para a distribuidora ou antecipam para o

(6) Preço Médio ao Consumidor Final (PMPF) estabelecido por Ato Cotepe / PMPF.

(7) Margem de Valor Agregado (MVA) estabelecido por Ato Cotepe / MVA (apenas na ausência do PMPF)

$$
\text { Fonte: ANP (2010). }
$$

De acordo com o Quadro 2, é possível notar que o preço de realização no produtor representa a base na formação de preço de toda a cadeia na comercialização do etanol, e este por sua vez 
conta com a Consecana, que se responsabiliza pela realização contratual entre plantadores de cana e usinas/destilarias produtoras de etanol - sendo este instante o momento em que se concretiza a realização do preço da principal matéria-prima do etanol (cana-de-açúcar, arbitrada por ATR pela Consecana). Segundo a Consecana (2010), o preço da cana-de-açúcar, como variável explicativa na formação de preço de etanol, é bastante significativo, uma vez que corresponde a cerca de $65 \%$ do custo de produção do etanol.

Assim, as alterações no preço da cana-de-açúcar têm reflexo imediato no preço do etanol, já que as usinas/destilarias tentam repassar esse incremento de custo aos consumidores, para não comprometerem suas respectivas margens de lucro. Isso será possível constatar no capítulo seguinte, quando será feita a análise quantitativa, em que a variável custo de produção também é fator de relação causal para a variável independente, preço do etanol hidratado. Além disto, cabe ressaltar que o ciclo na cultura da cana-de-açúcar e a sazonalidade também possuem suas relações na formação de preço do etanol, uma vez que a rotatividade da cultura da cana-de-açúcar é vital na preservação do solo e a safra representa o instante no qual a produção deve garantir o abastecimento na cadeia do etanol, e este deve ser suficiente para atender a entressafra com níveis de estoques capazes de abastecer o mercado interno. A Tabela 15, a seguir, traz um exemplo de como se compõem os custos na produção de etanol para usina/destilaria, segundo a Cepea/Esalq.

Tabela 15 - Decomposição do custo total de fabricação de etanol (2009)

\begin{tabular}{lcc}
\hline \multicolumn{1}{c}{ Itens de Despesa } & R\$ / ton. de cana & $\mathbf{R} \mathbf{\text { / m3 }}$ \\
Custo da matéria-prima (cana-de-açúcar) & 40,53 & 483,79 \\
Mão-de-obra & 3,67 & 43,81 \\
Insumos & 2,00 & 23,84 \\
Manutenção & 4,14 & 49,42 \\
Custo administração & 3,51 & 41,86 \\
Depreciação & 3,20 & 38,20 \\
Custo operacional da produção da cana e da fabricação do etanol & 57,05 & 680,92 \\
Custo de capital & 5,31 & 63,36 \\
Custo total de produção do etanol & 62,36 & 744,28 \\
\hline Custo total de produção do etanol por litro na porta da destilaria & $\mathbf{0 , 7 4 4}$ \\
\hline & Fonte: Cepea/Esalq (2010). & \\
É possível observar, conforme já mencionado, que 60\% da composição do custo de etanol na \\
usina/destilaria se referem à matéria-prima, cana-de-açúcar. Apesar de ser um dado um pouco \\
abaixo do que estima a Consecana, porém ambos os custos estimados são de expressiva
\end{tabular}


Quadro 2, a ANP na sua composição de preço do etanol considera também os tributos, e na Tabela 15 o enfoque analítico está apenas nos custos da produção do etanol.

Portanto, nota-se neste estudo que o mercado de combustível automotivo no Brasil, hoje, mais especificamente o etanol, apresenta uma dinâmica relacionada principalmente aos seguintes aspectos: o reflexo trazido na atual frota de veículos leves no Brasil via flex fuel; ganhos de produtividade da cana-de-açúcar decorrente da melhoria genética e da tecnologia na colheita da cana; custos de produção; tributos; fretes; frota, armazenagem, preços pagos ao produtor de cana-de-açúcar; possibilidades de usos da cana-de-açúcar, além da produção de etanol e açúcar; e normas regulatórias que visam coordenar o mercado com relação a fraudes fiscais e de adulteração de combustíveis. Estes aspectos servirão de base na constituição das variáveis dependentes para explicar quais são significativas na formação de preços, o que será discutido no capítulo seguinte. 


\section{RESULTADOS, DISCUSSÃO E ANÁLISE DOS DADOS}

Nos Capítulos 2 e 3, apresentou-se o entendimento da formação de preços e do mercado do combustível etanol, e posteriormente, no Capítulo 5, foram exploradas de forma descritiva e qualitativa as inferências acerca da formação de preços do mercado do etanol hidratado. As análises permitiram entender as principais variáveis que norteiam a formação de preços do referido combustível e, principalmente, relacioná-las, conforme sua intensidade, na diferenciação dos valores nas variadas regiões brasileiras. No sentido de enriquecer o recorte analítico, o Capítulo 6 faz uma imersão na análise dos preços do etanol hidratado nas macrorregiões do país de modo quantitativo, tomando-o como variável independente dentre as variáveis explicativas e constituídas a partir dos Capítulos 2, 3 e 5. A Tabela a seguir, nesse sentido, apresenta os dados e as variáveis, dependentes e independentes, que explicam a formação de preços. 
Quadro 3 - Séries de dados e variáveis que norteiam preços do etanol hidratado na revenda no ano de 2009

\begin{tabular}{|c|c|c|c|c|c|c|c|c|c|c|c|c|c|c|c|c|}
\hline $\begin{array}{l}\text { Grandes Regiões e } \\
\text { Unidades da } \\
\text { Federação }\end{array}$ & $\begin{array}{c}\text { Preço: } \\
\text { Revenda R\$ } \\
\text { (I) }\end{array}$ & $\begin{array}{c}\text { Preço: } \\
\text { Distribuidora } \\
\text { R\$ (I) }\end{array}$ & $\begin{array}{c}\text { Preço: } \\
\text { Produtor } \\
\text { RS (I) }\end{array}$ & $\begin{array}{c}\text { Preço: } \\
\text { Gasolina C R\$ } \\
\text { (I) }\end{array}$ & $\begin{array}{c}\text { Preço: } \\
\text { Açúcar } \\
\text { Exportação } \\
\mathbf{R} \text { (t) }\end{array}$ & \begin{tabular}{c|} 
№ postos \\
revendedores
\end{tabular} & $\begin{array}{c}\text { № postos } \\
\text { bandeira } \\
\text { branca }\end{array}$ & $\begin{array}{c}\text { № } \\
\text { distribuidoras }\end{array}$ & \begin{tabular}{|c|}
$\begin{array}{c}\text { Capacidade nominal } \\
\text { de armazenamento }\left(\mathrm{m}^{3}\right)\end{array}$ \\
Etanol
\end{tabular} & $\begin{array}{c}\text { Produção: Etanol } \\
\qquad\left(10_{3} \mathrm{~m}_{3}\right)\end{array}$ & $\begin{array}{l}\text { Produção: } \\
\text { Açúcar (t) }\end{array}$ & $\begin{array}{l}\text { Frota carros: } \\
\text { etanol e flex }\end{array}$ & $\begin{array}{c}\text { № usinas de } \\
\text { açúcar e } \\
\text { etanol }\end{array}$ & \begin{tabular}{|l|}
$\mathrm{e}$ \\
Frete $\mathrm{R} \$(\mathrm{I})$
\end{tabular} & \begin{tabular}{|c|} 
Impostos \\
sobre o preço \\
final pago na \\
bomba \\
R\$ (I)
\end{tabular} & $\begin{array}{l}\text { Custos: } \\
\text { Produção } \\
\text { Etanol } \\
\text { Hidratado } \\
\text { R\$ (I) }\end{array}$ \\
\hline Brasil & 1,953 & 1,568 & 0,968 & 2,581 & 541,41 & 20.813 & 15.917 & 508 & 578.153 & 26.105 & 31.049.206 & 15.011.387 & 421 & 0,07 & 0,63 & 0,51 \\
\hline Região Norte & 2,198 & 1,780 & 0,896 & 2,713 & & 1.190 & 1.196 & 56 & 44.523 & 53 & 28.046 & 399.707 & 4 & 0,09 & 0,76 & 0,66 \\
\hline Rondônia & 2,067 & 1,716 & 1,271 & 2,631 & & 196 & 239 & 12 & 10.228 & 8,55 & - & 62.614 & 1 & 0,07 & 0,70 & 0,92 \\
\hline Acre & 2,451 & 1,889 & 1,238 & 2,929 & & 70 & 55 & 5 & 2.458 & 1,48 & & 20.782 & - & 0,08 & 0,78 & 1,16 \\
\hline Amazonas & 2,235 & 1,798 & 1,326 & 2,556 & & 309 & 181 & 8 & 13.121 & 4,74 & 14.320 & 106.414 & 1 & 0,11 & 0,75 & 1,00 \\
\hline Roraima & 2,312 & 1,967 & 0,000 & 2,691 & & 58 & 38 & 2 & 1.611 & - & & 16.848 & - & 0,10 & 0,78 & \\
\hline Pará & 2,241 & 1,855 & 1,216 & 2,738 & & 384 & 440 & 24 & 14.818 & 36,00 & 13.726 & 124.143 & 1 & 0,09 & 0,90 & 0,84 \\
\hline Amapá & 2,185 & 1,696 & 0,000 & 2,700 & & 57 & 42 & 1 & 1.184 & - & - & 21.162 & 1 & 0,14 & 0,73 & \\
\hline Tocantins & 1,894 & 1,537 & 1,224 & 2,746 & & 116 & 201 & 4 & 1.103 & 2,42 & - & 47.744 & 1 & 0,06 & 0,69 & 0,69 \\
\hline Região Nordeste & 1,959 & 1,675 & 1,139 & 2,560 & & 4.059 & 3.776 & 74 & 98.317 & 2.211 & 4.271.341 & 1.676 .195 & 77 & 0,07 & 0,66 & 0,55 \\
\hline Maranhão & 2,016 & 1,669 & 1,095 & 2,583 & & 303 & 565 & 8 & 22.022 & 168,50 & 15.335 & 102.523 & 4 & 0,09 & 0,71 & 0,63 \\
\hline Piauí & 2,072 & 1,718 & 1,268 & 2,549 & & 202 & 422 & 1 & 4.681 & 40,95 & 38.796 & 75.685 & 1 & 0,08 & 0,72 & 0,59 \\
\hline Ceará & 2,011 & 1,703 & 1,230 & 2,501 & & 694 & 450 & 11 & 15.073 & 10,76 & - & 277.059 & 2 & 0,06 & 0,70 & 0,62 \\
\hline Rio Grande do Norte & 1,966 & 1,687 & 1,203 & 2,586 & & 331 & 230 & 4 & 867 & 117,30 & 197.914 & 137.522 & 4 & 0,07 & 0,66 & 0,55 \\
\hline Paraíba & 1,862 & 1,635 & 1,139 & 2,399 & & 298 & 332 & 4 & 9.501 & 395,30 & 133.883 & 128.706 & 9 & 0,07 & 0,65 & 0,54 \\
\hline Pernambuco & 1,890 & 1,789 & 1,156 & 2,565 & & 758 & 532 & 12 & 21.717 & 469,03 & 1.521 .275 & 345.979 & 24 & 0,03 & 0,59 & 0,43 \\
\hline Alagoas & 1,950 & 1,722 & 1,060 & 2,696 & & 245 & 192 & 4 & 4.529 & 790,99 & 2.200 .862 & 85.735 & 24 & 0,06 & 0,69 & 0,44 \\
\hline Sergipe & 1,968 & 1,691 & 1,204 & 2,547 & & 178 & 61 & 3 & 2.826 & 101,12 & 82.099 & 83.366 & 6 & 0,06 & 0,73 & 0,53 \\
\hline Bahia & 1,894 & 1,458 & 0,899 & 2,615 & & 1.050 & 992 & 27 & 17.101 & 116,56 & 81.177 & 439.619 & 3 & 0,07 & 0,47 & 0,62 \\
\hline Região Sudeste & 1,850 & 1,496 & 0,947 & 2,482 & & 8.445 & 7.090 & 204 & 299.031 & 17.676 & 22.196.386 & 8.500 .428 & 250 & 0,06 & 0,55 & 0,53 \\
\hline Minas Gerais & 1,905 & 1,527 & 0,899 & 2,378 & & 2.281 & 1.890 & 34 & 45.151 & $2.284,23$ & 2.207 .621 & 1.584 .087 & 37 & 0,07 & 0,60 & 0,54 \\
\hline Espírito Santo & 2,060 & 1,726 & 1,091 & 2,622 & & 425 & 209 & 8 & 9.960 & 238,35 & 85.324 & 264.370 & 6 & 0,07 & 0,72 & 0,61 \\
\hline Rio de Janeiro & 1,896 & 1,501 & 0,899 & 2,544 & & 1.244 & 891 & 30 & 57.088 & 112,82 & 241.005 & 1.282 .428 & 7 & 0,06 & 0,58 & 0,53 \\
\hline São Paulo & 1,540 & 1,231 & 0,899 & 2,384 & & 4.495 & 4.100 & 132 & 186.832 & $15.041,00$ & 19.662 .436 & 5.369 .543 & 200 & 0,04 & 0,31 & 0,43 \\
\hline Região Sul & 1,907 & 1,494 & 0,899 & 2,507 & & 5.585 & 2.202 & 110 & 85.179 & 1.901 & 2.459 .512 & 3.236.259 & 34 & 0,07 & 0,56 & 0,36 \\
\hline Paraná & 1,661 & 1,388 & 0,899 & 2,445 & & 1.572 & 1.216 & 57 & 47.506 & $1.898,80$ & 2.459 .512 & 1.239 .395 & 33 & 0,05 & 0,41 & 0,46 \\
\hline Santa Catarina & 1,997 & 1,526 & 0,899 & 2,536 & & 1.535 & 492 & 22 & 6.428 & - & - & 801.491 & - & 0,08 & 0,64 & - \\
\hline Rio Grande do Sul & 2,062 & 1,569 & 0,899 & 2,539 & & 2.478 & 494 & 31 & 31.245 & 2,46 & 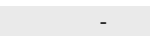 & 1.195 .373 & 1 & 0,09 & 0,65 & 0,61 \\
\hline Região Centro-Oeste & 1,852 & 1,393 & 0,957 & 2,641 & & 1.534 & 1.653 & 64 & 51.103 & 4.263 & 2.093 .921 & 1.198 .798 & 56 & 0,06 & 0,61 & 0,46 \\
\hline Mato Grosso do Sul & 1,918 & 1,582 & 1,132 & 2,620 & & 420 & 164 & 12 & 9.124 & $1.331,48$ & 657.078 & 181.312 & 14 & 0,06 & 0,72 & 0,63 \\
\hline Mato Grosso & 1,747 & 1,359 & 1,152 & 2,689 & & 352 & 598 & 24 & 12.589 & 809,92 & 478424 & 166.750 & 11 & 0,07 & 0,59 & 0,65 \\
\hline Goiás & 1,714 & 1,221 & 0,773 & 2,576 & & 515 & 824 & 18 & 18.843 & $2.121,83$ & 958.419 & 475.275 & 29 & 0,04 & 0,48 & 0,55 \\
\hline Distrito Federal & 2,027 & 1,412 & 0,773 & 2,680 & & 247 & 67 & 10 & 10.547 & - & - & 375.462 & 2 & 0,06 & 0,64 & - \\
\hline
\end{tabular}

Fonte: Desenvolvida pelo autor. Dados de 2009 extraídos das seguintes instituições: Orplana, Única, MAPA, ANP, Denatran, Sindicom, CEPEA/Esalq e Copersucar. 
O Quadro 3 demonstra as variáveis, dados secundários, em que as séries de preços do etanol hidratado na revenda, distribuidor e produtor, número de postos revendedores e de "bandeira branda", número de distribuidoras, capacidade de armazenagem e produção de etanol foram aferidos pela ANP. A série de dados relativos à produção de açúcar é aferida pelo MAPA. Já a série de dados da variável frota de carros movidos a etanol e flex foi coletada junto ao Denatran. Os dados da variável número de usinas de açúcar e etanol foram obtidos junto à UNICA. A série de dados relacionados a frete foi interpolada pelas informações colhidas na Cepea/Esalq e Sindicom. Os dados da variável impostos sobre o preço final pago na bomba foram colhidos junto ao Sindicom. Por fim, a série de dados da variável custo de produção foi interpolada pelas informações coletadas na Copersucar e Orplana. A variável preço do açúcar na exportação foi colhida junto a UNICA, e sua representatividade será discutida, pois se trata de uma variável interveniente, praticada nacionalmente, não sofrendo variação entre os Estados.

Desse modo, a partir das evidências empíricas e dedutíveis já apresentadas no Capítulo 5, nesta seção, será feita uma análise mais criteriosa mediante o uso das ferramentas estatísticas: regressão linear múltipla e análise da variância. Portanto, este capítulo juntamente com o anterior retomam os objetivos deste trabalho, destacando seus resultados, considerações e propondo questões relativas às limitações desta pesquisa e às sugestões para futuros estudos.

Os resultados obtidos são apresentados de acordo com a metodologia aplicada, cuja análise qualitativa se complementa pela quantitativa. Para análise qualitativa, observaram-se as principais variáveis como enfoque para constituição dos dados e discussão do estudo relativo à cadeia produtiva do etanol hidratado, formação de preços, tecnologias, estruturas e mercado. Vale enfatizar que os dados apresentados no Quadro 3 compreendem as médias obtidas no ano de 2009, não sendo possível emparelhar com outros anos, dada a limitação do acesso a esses dados.

As hipóteses levantadas para a ANOVA é de que existe uma diferença entre as regiões em relação a (etanol/gasolina), sendo esta $\mathrm{H} 1$ (hipótese alternativa). E para a regressão, a hipótese é de que existe ao menos um fator que interfere no preço de revenda do etanol (H1). E sendo Ho (hipótese nula) a ausência de relacionamento significativo nas diferenças de preços entre as variáveis etanol hidratado e gasolina $\mathrm{C}$. 
Os resultados da análise estatística são aqui compreendidos como descritivos, por observar como o conjunto dos dados se comportou por meio das tabelas e gráficos, sendo que valores de $\mathrm{p}>0.05$ indicam que não há diferenças entre os objetos comparados, e valores $\mathrm{p}<0.05$ indicam diferenças estatísticas (estes são os resultados que podem ser estatisticamente considerados e discutidos).

\subsection{Análise descritiva das variáveis para formação de preços}

A análise inicia-se a partir do Quadro 3. A seguir, as Tabelas 16 e 17 apresentam as descritivas das variáveis estudadas, por meio das quais é possível resumir o comportamento do conjunto de dados. Ou seja, inicialmente nesta seção, investiga-se apenas como os dados se comportam. Posteriormente, será analisado o resultado da regressão linear múltipla, observando qual variável dependente irá apresentar um p-valor significativo para o teste de hipóteses, possibilitando, por sua vez, inferir as variáveis dependentes que explicam a formação de preços do etanol hidratado. De acordo com Hair et. al (2005b), o p-valor representa o menor nível de significância para rejeitar uma hipótese nula, sendo que o nível de significância é a probabilidade de se rejeitar Ho quando Ho é verdadeira. Sabe-se que:

Ho (hipótese nula) - não existe relacionamento significativo nas diferenças de preços entre as variáveis etanol hidratado e gasolina $\mathrm{C}$.

$\mathrm{H}_{1}$ (hipótese alternativa 1) - existe um relacionamento significativo nas diferenças de preços entre as variáveis etanol hidratado e gasolina $\mathrm{C}$.

Assim, a este nível de significância Ho, foi adotado por convenção um nível de 0,05 , ou 5\%, ao qual coube realizar um teste $\mathrm{t}$ de student não pareado, uma vez que suas médias não são iguais à hipótese H1. Com relação ao comportamento descritivo dos dados, tem-se:

a) a média fornece o ponto ao redor do qual os dados se agrupam;

b) o intervalo de confiança para a média permite fazer inferências para a população estudada;

c) o desvio padrão dá ideia de variabilidade, possibilitando avaliar o quanto os dados estão dispersos, em média, ao redor da média;

d) $01^{\circ}$ quartil separa os primeiros $25 \%$ dos dados;

e) a mediana separa os primeiros $50 \%$ dos dados, ou seja, é o valor que divide o conjunto de dados na metade;

f) o $3^{\circ}$ quartil separa os primeiros $75 \%$ dos dados. 
Tabela 16 - Descrição das variáveis por Região (2009)

\begin{tabular}{|c|c|c|c|c|c|c|c|c|c|}
\hline \multirow[t]{2}{*}{ Região } & \multirow{2}{*}{$\begin{array}{l}\text { Variável } \\
\text { Preço: Revenda R\$ (l) }\end{array}$} & \multirow{2}{*}{$\begin{array}{l}\mathbf{N} \\
4\end{array}$} & \multirow{2}{*}{$\begin{array}{r}\text { Média } \\
1,85\end{array}$} & \multicolumn{2}{|c|}{$\begin{array}{l}\text { Intervalo de confiança } \\
\text { 95\% para média }\end{array}$} & \multirow{2}{*}{$\begin{array}{r}\begin{array}{c}\text { Desvio } \\
\text { padrão }\end{array} \\
0,15\end{array}$} & \multirow{2}{*}{$\begin{array}{r}\mathbf{1}^{\mathbf{0}} \text { Quartil } \\
1,73\end{array}$} & \multirow{2}{*}{$\begin{array}{r}\text { Mediana } \\
1,83\end{array}$} & \multirow{2}{*}{$\begin{array}{r}\mathbf{3}^{\circ} \text { Quartil } \\
1,97\end{array}$} \\
\hline & & & & 1,62 & 2,09 & & & & \\
\hline & Preço: Distribuidora R \$ (1) & 4 & 1,39 & 1,16 & 1,63 & 0,15 & 1,29 & 1,39 & 1,5 \\
\hline & Preço: Gasolina C R\$ (1) & 4 & 2,64 & 2,56 & 2,73 & 0,05 & 2,6 & 2,65 & 2,68 \\
\hline & Preço: Açúcar ExportaçãoR \$ (t) & 4 & 541,41 & - & - & 0 & 541,41 & 541,41 & 541,41 \\
\hline & $\mathrm{N}^{\circ}$ postos revendedores & 4 & 383,5 & 203,83 & 563,17 & 112,91 & 299,5 & 386 & 467,5 \\
\hline & $\mathrm{N}^{\mathrm{o}}$ distribuidoras & 4 & 16 & 5,94 & 26,06 & 6,32 & 11 & 15 & 21 \\
\hline \multirow{7}{*}{$\begin{array}{l}\text { Centro- } \\
\text { Oeste }\end{array}$} & Capacid. nominal de armaz. do Etanol $\left(\mathrm{m}^{3}\right)$ & 4 & $12.775,7$ & $5.953,3$ & $19.598,1$ & $4.287,5$ & $9.835,5$ & $11.568,0$ & $15.716,0$ \\
\hline & Produção: Etanol (103 m3 ) & 3 & $1.421,0$ & $-219,7$ & $3.061,9$ & 660,5 & 809,9 & $1.331,4$ & $2.121,8$ \\
\hline & Produção: Açúcar (t) & 3 & $697.973,7$ & $95.330,1$ & $130.0617,0$ & $242.596,7$ & 47842 & $657.078,0$ & $958.419,0$ \\
\hline & Frota carros flex & 4 & $349.300,0$ & $69.556,9$ & $629.043,1$ & $175.803,8$ & $202.833,0$ & $324.460,0$ & $495.767,0$ \\
\hline & Custos: Produção Etanol Hidratado R \$ (1) & 3 & 0,61 & 0,48 & 0,74 & 0,05 & 0,55 & 0,63 & 0,65 \\
\hline & Preço: Revenda R\$ (1) & 9 & 1,96 & 1,91 & 2,01 & 0,07 & 1,89 & 1,97 & 2,01 \\
\hline & Preço: Distribuidora R \$ (1) & 9 & 1,67 & 1,6 & 1,74 & 0,09 & 1,67 & 1,69 & 1,72 \\
\hline \multirow{4}{*}{ Nordeste } & Preço: Produtor R \$ (1) & 9 & 1,14 & 1,05 & 1,23 & 0,11 & 1,1 & 1,16 & 1,2 \\
\hline & Preço: Gasolina C R\$ (1) & 9 & 2,56 & 2,5 & 2,62 & 0,08 & 2,55 & 2,57 & 2,59 \\
\hline & Preço: Açúcar ExportaçãoR \$ (t) & 9 & 541,41 & - & - & 0 & 541,41 & 541,41 & 541,41 \\
\hline & $\mathrm{N}^{\circ}$ postos revendedores & 9 & 451 & 215,52 & 686,48 & 306,34 & 245 & 303 & 694 \\
\hline
\end{tabular}




\begin{tabular}{|c|c|c|c|c|c|c|c|c|c|}
\hline & $\mathrm{N}^{\circ}$ postos bandeira branca & 9 & 419,56 & 211,45 & 627,66 & 270,73 & 230 & 422 & 532 \\
\hline & $\mathrm{N}^{\circ}$ distribuidoras & 9 & 8,22 & 2,1 & 14,34 & 7,97 & 4 & 4 & 11 \\
\hline & Capacid. nominal de armaz. do Etanol $\left(\mathrm{m}^{3}\right)$ & 9 & $10.924,1$ & $4.587,6$ & $17.260,62$ & $8.243,49$ & 4.529 & 9.501 & 17.101 \\
\hline & Produção: Etanol (103 m3 ) & 9 & 245,61 & 48,37 & 442,85 & 256,6 & 101,12 & 117,3 & 395,3 \\
\hline & Produção: Açúcar (t) & 8 & $533.917,6$ & -169.085 & 1.236 .921 & $840.891,7$ & $59.986,5$ & 107.991 & $859.594,5$ \\
\hline & Frota carros flex & 9 & $217.067,4$ & $97.053,84$ & $337.081,1$ & $156.131,9$ & 99.924 & 150.007 & 322.913 \\
\hline & $\mathrm{N}^{\circ}$ usinas de açúcar e etanol & 9 & 8,56 & 1,59 & 15,52 & 9,06 & 3 & 4 & 9 \\
\hline & Frete $\mathrm{R} \$(1)$ & 9 & 0,07 & 0,05 & 0,08 & 0,02 & 0,06 & 0,07 & 0,07 \\
\hline & Impostos sobre o preço final pago na bomba $\mathrm{R} \$(1)$ & 9 & 0,66 & 0,6 & 0,72 & 0,08 & 0,65 & 0,69 & 0,71 \\
\hline & Custos: Produção Etanol Hidratado R \$ (1) & 9 & 0,55 & 0,49 & 0,61 & 0,07 & 0,53 & 0,55 & 0,62 \\
\hline \multirow{14}{*}{ Norte } & Preço: Revenda R \$ (1) & 7 & 2,2 & 2,03 & 2,36 & 0,18 & 2,07 & 2,24 & 2,31 \\
\hline & Preço: Distribuidora R \$ (1) & 7 & 1,78 & 1,65 & 1,91 & 0,14 & 1,7 & 1,8 & 1,89 \\
\hline & Preço: Produtor R \$ (1) & 5 & 1,25 & 1,2 & 1,31 & 0,04 & 1,22 & 1,24 & 1,27 \\
\hline & Preço: Gasolina C R\$ (1) & 7 & 2,71 & 2,61 & 2,82 & 0,12 & 2,63 & 2,7 & 2,75 \\
\hline & Preço: Açúcar ExportaçãoR \$ (t) & 7 & 541,41 & - & - & 0 & 541,41 & 541,41 & 541,41 \\
\hline & $\mathrm{N}^{\circ}$ postos revendedores & 7 & 170 & 48,23 & 291,77 & 131,67 & 58 & 116 & 309 \\
\hline & $\mathrm{N}^{\mathrm{o}}$ postos bandeira branca & 7 & 170,86 & 36,96 & 304,76 & 144,78 & 42 & 181 & 239 \\
\hline & $\mathrm{N}^{\mathrm{o}}$ distribuidoras & 7 & 8 & 0,62 & 15,38 & 7,98 & 2 & 5 & 12 \\
\hline & Capacid. nominal de armaz. do Etanol $\left(\mathrm{m}^{3}\right)$ & 7 & $6.360,43$ & 704,28 & $12.016,57$ & $6.115,77$ & 1.184 & 2.458 & 13.121 \\
\hline & Produção: Etanol (103 m3 ) & 5 & 10,64 & $-7,29$ & 28,56 & 14,44 & 2,42 & 4,74 & 8,55 \\
\hline & Produção: Açúcar (t) & 2 & 14.023 & $10.249,26$ & $17.796,74$ & 420,02 & 13.726 & 14.023 & 14.320 \\
\hline & Frota carros flex & 7 & $69.510,86$ & $17.573,9$ & $121.447,8$ & $56.157,43$ & 24.221 & 55.646 & 124.026 \\
\hline & $\mathrm{N}^{\circ}$ usinas de açúcar e etanol & 4 & 1 & - & - & 0 & 1 & 1 & 1 \\
\hline & Frete $\mathrm{R} \$(1)$ & 7 & 0,09 & 0,07 & 0,12 & 0,03 & 0,07 & 0,09 & 0,11 \\
\hline
\end{tabular}




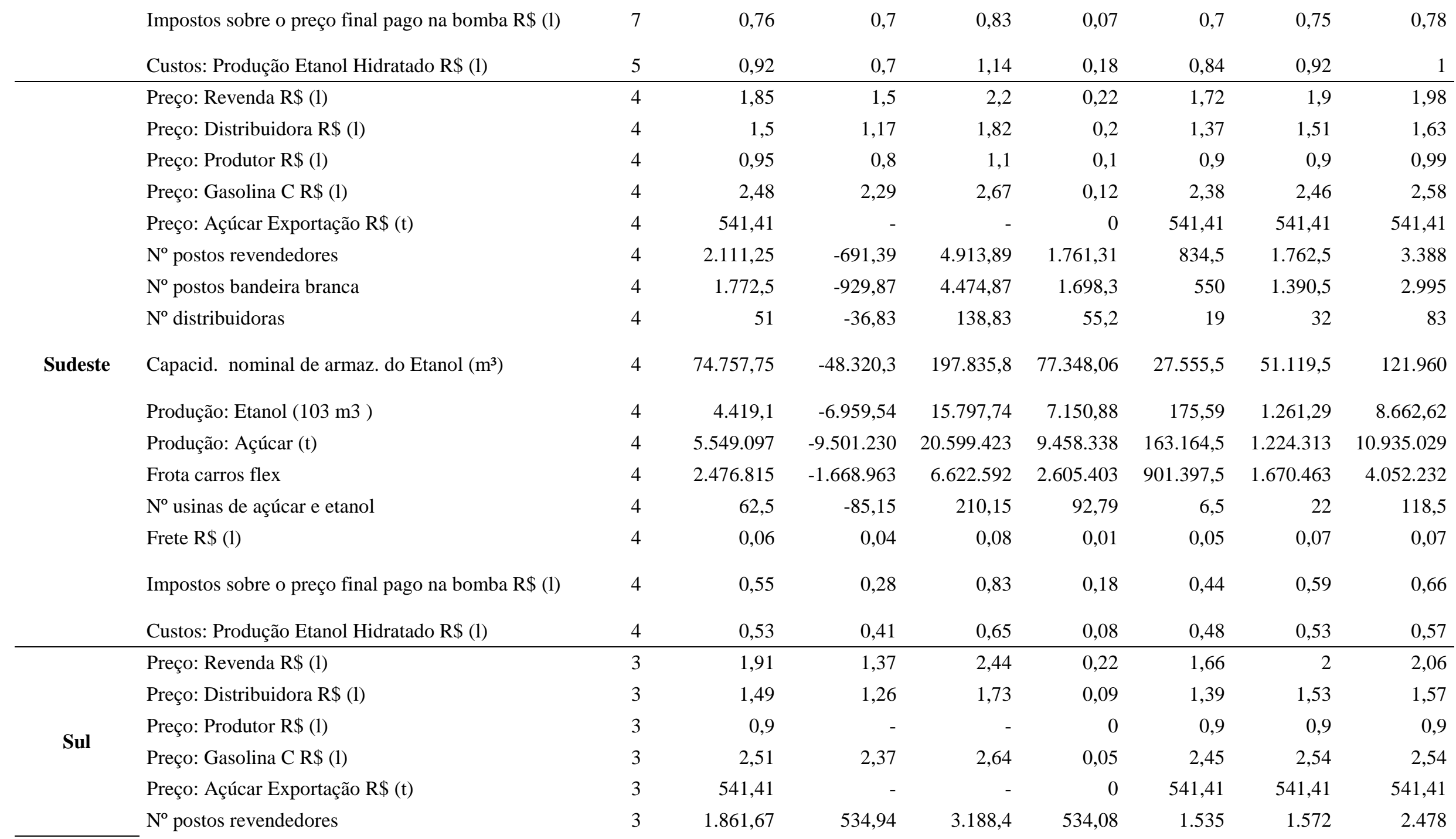




\begin{tabular}{|c|c|c|c|c|c|c|c|c|}
\hline $\mathrm{N}^{\circ}$ postos bandeira branca & 3 & 734 & $-302,94$ & $1.770,94$ & 417,43 & 492 & 494 & 1216 \\
\hline $\mathrm{N}^{\mathrm{o}}$ distribuidoras & 3 & 36,67 & $-8,48$ & 81,82 & 18,18 & 22 & 31 & 57 \\
\hline Capacid. nominal de armaz. do Etanol $\left(\mathrm{m}^{3}\right)$ & 3 & 28.393 & $-22.996,3$ & $79.782,3$ & $20.686,98$ & 6.428 & 31.245 & 47.506 \\
\hline Produção: Etanol (103 m3 ) & 2 & 950,63 & -1.1097 & $12.998,27$ & $1.340,91$ & 2,46 & 950,63 & $1.898,8$ \\
\hline Produção: Açúcar (t) & 1 & 2.459 .512 & - & - & - & 2.459 .512 & 2.459 .512 & 2.459 .512 \\
\hline Frota carros flex & 3 & 1.257 .288 & $559.174,3$ & 1.955 .402 & $281.028,6$ & 934.139 & 1.393.209 & 1.444 .516 \\
\hline $\mathrm{N}^{\circ}$ usinas de açúcar e etanol & 2 & 17 & $-186,3$ & 220,3 & 22,63 & 1 & 17 & 33 \\
\hline Frete $\mathrm{R} \$(1)$ & 3 & 0,07 & 0,02 & 0,13 & 0,02 & 0,05 & 0,08 & 0,09 \\
\hline Impostos sobre o preço final pago na bomba $\mathrm{R} \$$ (l) & 3 & 0,56 & 0,23 & 0,9 & 0,13 & 0,41 & 0,64 & 0,65 \\
\hline Custos: Produção Etanol Hidratado R \$ (1) & 2 & 0,54 & $-0,41$ & 1,48 & 0,11 & 0,46 & 0,54 & 0,61 \\
\hline
\end{tabular}


A partir da Tabela 17, percebe-se que a principal variável estudada, preço de revenda, apresenta maior média para região Norte, enquanto as duas menores médias são observadas nas regiões Centro-Oeste e Sudeste. E por se tratar de uma descritiva, significa simplesmente constatar inicialmente que o valor da média encontrada no seu conjunto de dados é maior ou menor para as regiões citadas. Portanto, nesta etapa de análise não se realizam inferências.

Tabela 17 - Descrição da relação etanol/gasolina por região (2009)

\begin{tabular}{|c|c|c|c|c|c|c|c|c|}
\hline \multirow{2}{*}{$\begin{array}{r}\text { Região } \\
\text { Centro-Oeste }\end{array}$} & \multirow{2}{*}{$\begin{array}{l}\mathbf{N} \\
4\end{array}$} & \multirow{2}{*}{$\begin{array}{c}\text { Média } \\
0,7\end{array}$} & \multicolumn{2}{|c|}{$\begin{array}{c}\text { Intervalo de } \\
\text { confiança } 95 \% \text { para } \\
\text { média } \\
\end{array}$} & \multirow{2}{*}{$\begin{array}{c}\begin{array}{c}\text { Desvio } \\
\text { padrão }\end{array} \\
0,05\end{array}$} & \multirow{2}{*}{$\begin{array}{c}\mathbf{1}^{\mathbf{0}} \\
\text { Quartil } \\
0,66\end{array}$} & \multirow{2}{*}{$\begin{array}{c}\text { Mediana } \\
0,7\end{array}$} & \multirow{2}{*}{$\begin{array}{c}\mathbf{3}^{\mathbf{o}} \\
\text { Quartil } \\
0,74\end{array}$} \\
\hline & & & 0,62 & 0,78 & & & & \\
\hline Nordeste & 9 & 0,77 & 0,74 & 0,79 & 0,03 & 0,74 & 0,77 & 0,78 \\
\hline Norte & 7 & 0,81 & 0,75 & 0,87 & 0,06 & 0,79 & 0,82 & 0,86 \\
\hline Sudeste & 4 & 0,74 & 0,63 & 0,86 & 0,07 & 0,7 & 0,77 & 0,79 \\
\hline Sul & 3 & 0,76 & 0,58 & 0,94 & 0,07 & 0,68 & 0,79 & 0,81 \\
\hline
\end{tabular}

No entanto, cabe destacar que, de acordo com a Tabela 17, acima, é possível notar que parece ser econômicamente vantajoso abastecer com etanol apenas na região Centro-Oeste, pois a média da relação etanol/gasolina é a menor dentre as cinco regiões, enquanto a região Norte apresenta maior média, porém esta será melhor corroborada com a análise de variância. A seguir, será apresentada graficamente a média dos preços na revenda e da relação etanol hidratado e gasolina C, dentre as diversas macrorregiões do país referente ao ano de 2009.

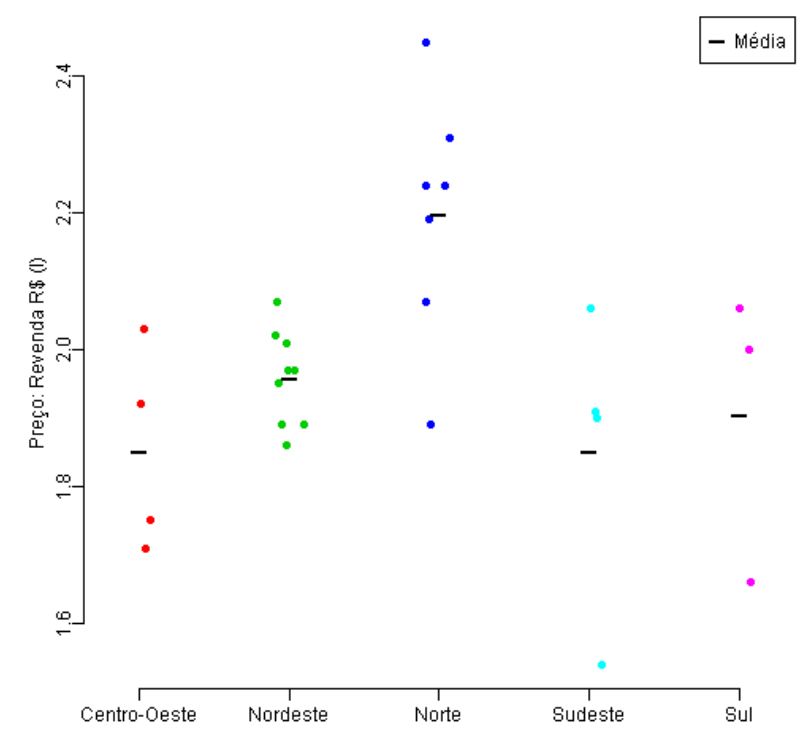

Gráfico 7 - Preço de Revenda por região

O Gráfico 7 permite compreender que a região Norte apresenta valores mais elevados de preço de revenda do etanol, ao passo que as regiões Sudeste e Centro-Oeste revelam valores 
menores. Estes valores sofrem maiores variações na região Norte, enquanto a região Nordeste apresenta valores mais condensados.

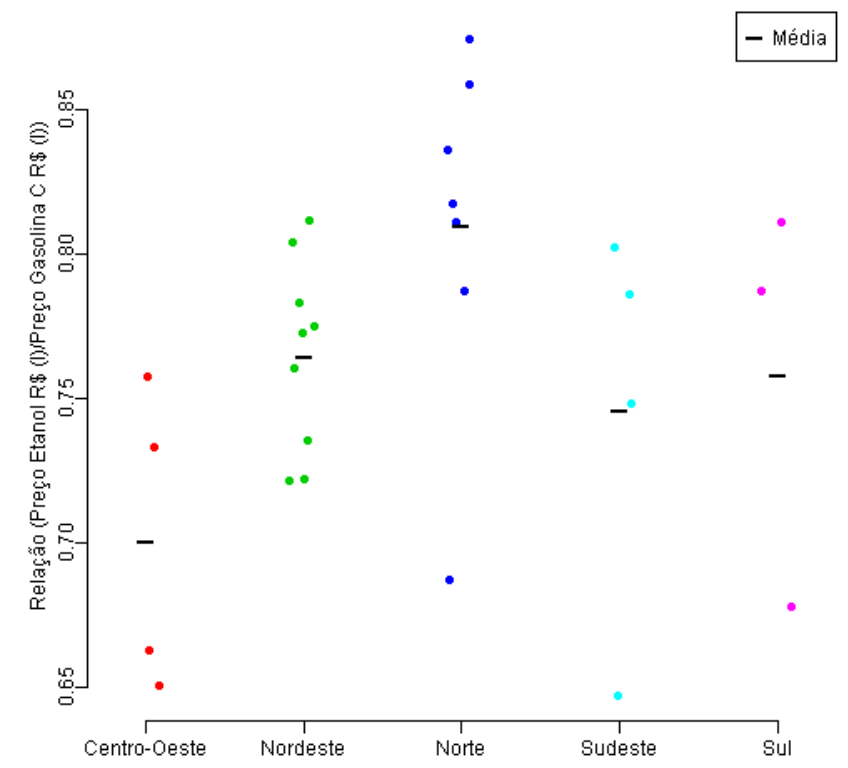

Gráfico 8 - Relação (preço etanol/preço gasolina) por região

A região Norte, de acordo com o Gráfico 8, demonstra claramente que é a região menos vantajosa no abastecimento de etanol hidratado, pois a maioria dos valores está acima do limiar 0,7, enquanto as regiões Sudeste e Centro-Oeste apresentam valores mais próximos deste limiar.

Os gráficos 9-A a 9-O a seguir, demonstram a relação entre preço de revenda com todas as variáveis explicativas propostas neste estudo.

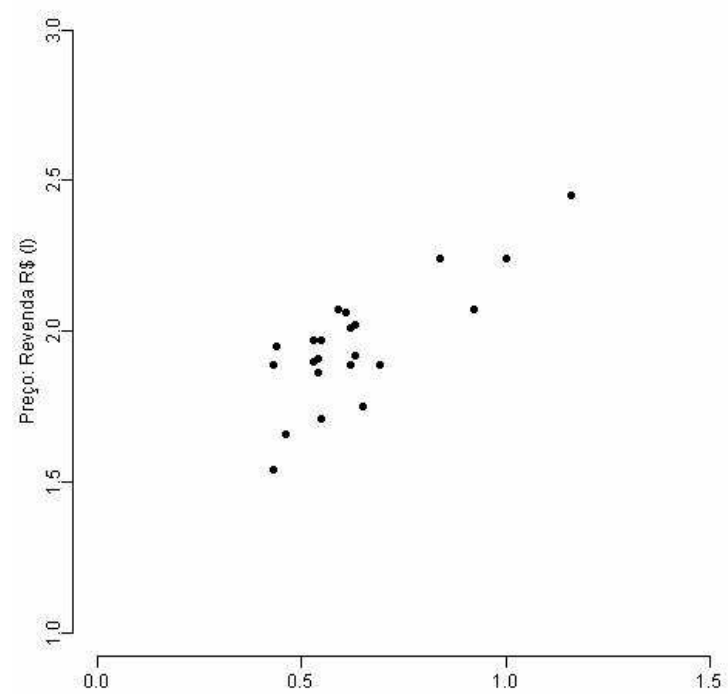

A-) Custos: Produção etanol hidratado R\$ (l)

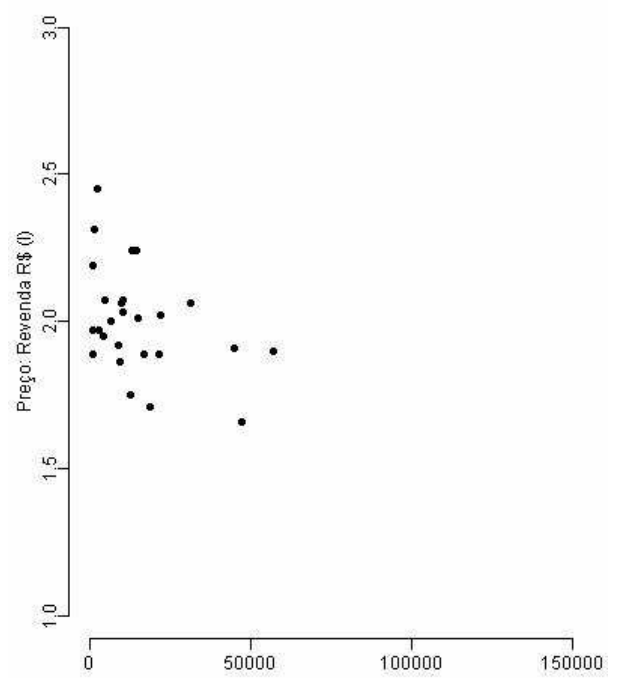

B-) Capacidade nominal de armazenagem do etanol $\left(\mathbf{m}^{3}\right)$ 


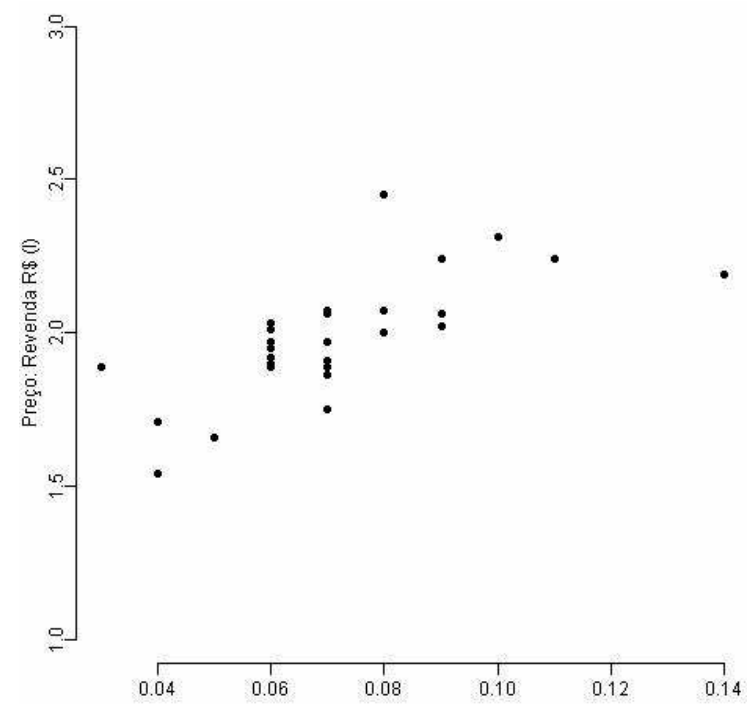

C-) Frete R\$ (1)

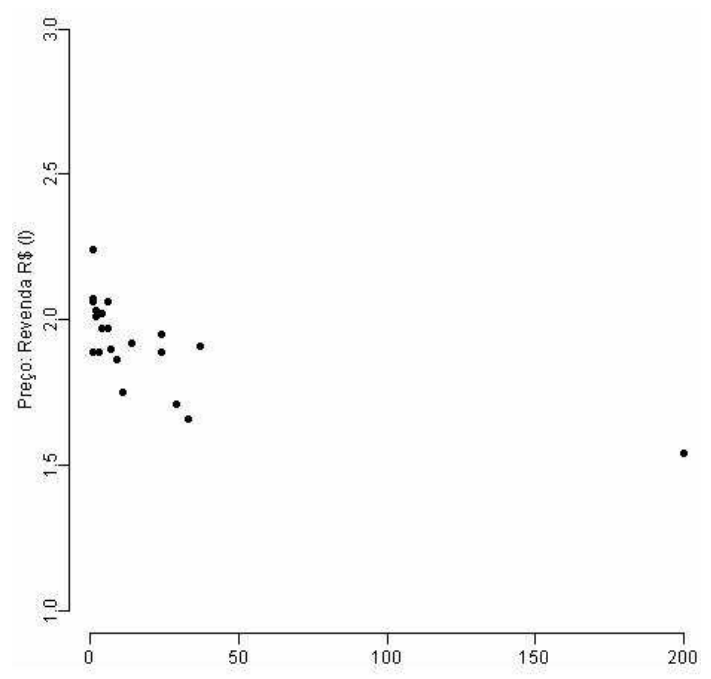

E-) nº. de usinas: açúcar e etanol

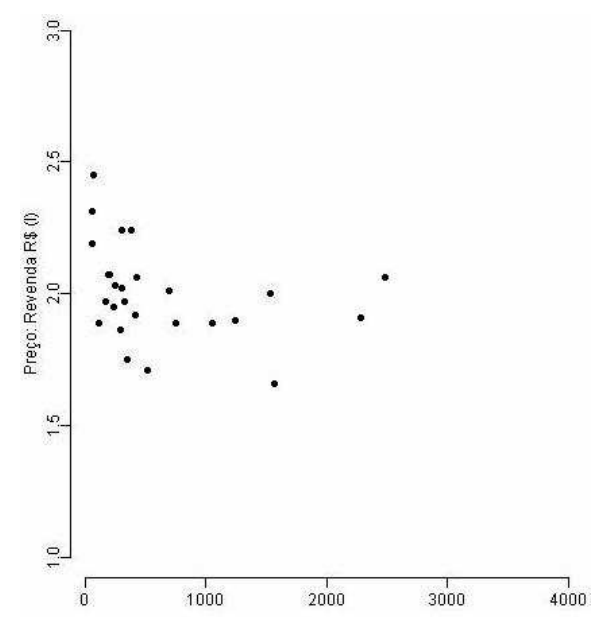

G-) $\mathbf{n}^{\mathbf{0}}$. de postos revendedores

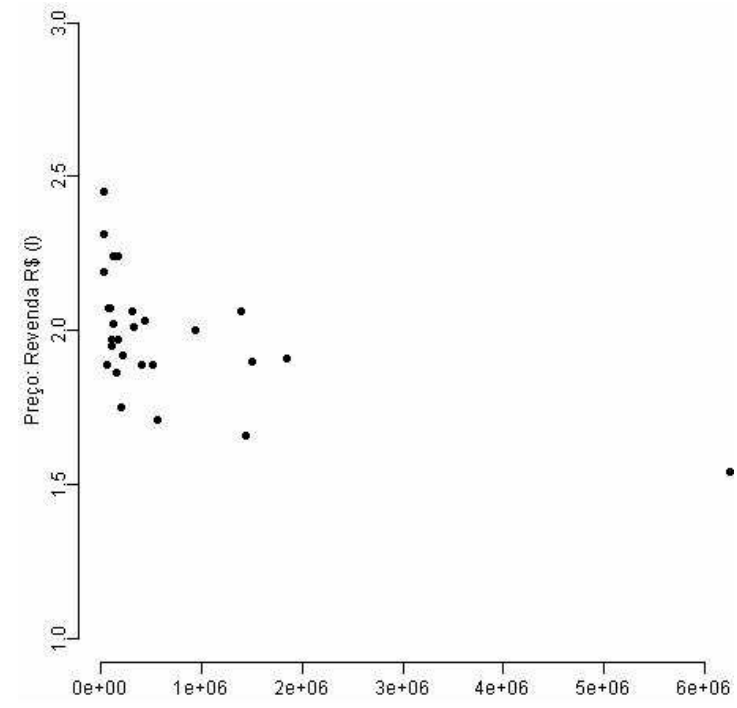

D-) Frota: carros flex

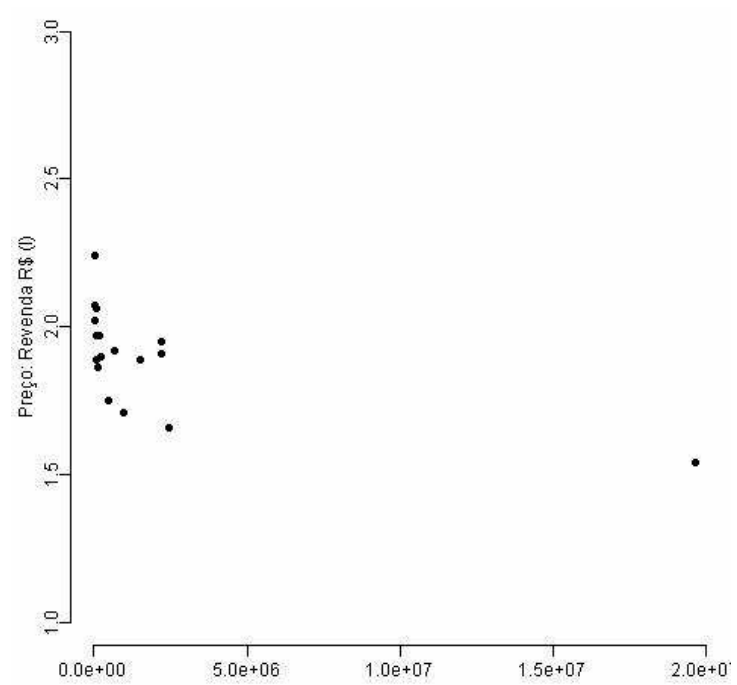

F-) Produção: açúcar (t)

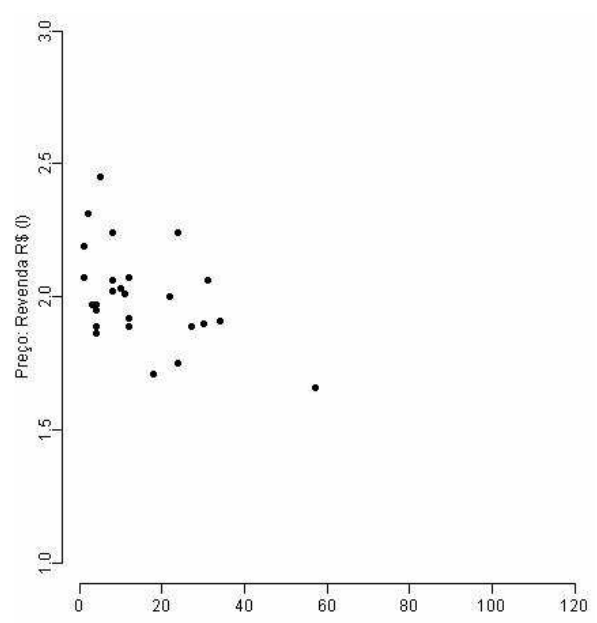

H-) $\mathbf{n}^{\circ}$. de distribuidoras 


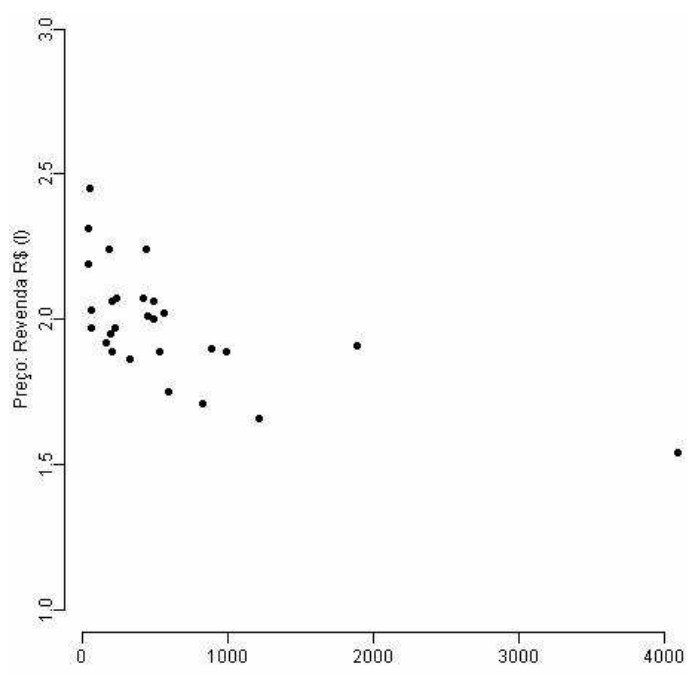

I-) $n^{0}$. de postos bandeira branca

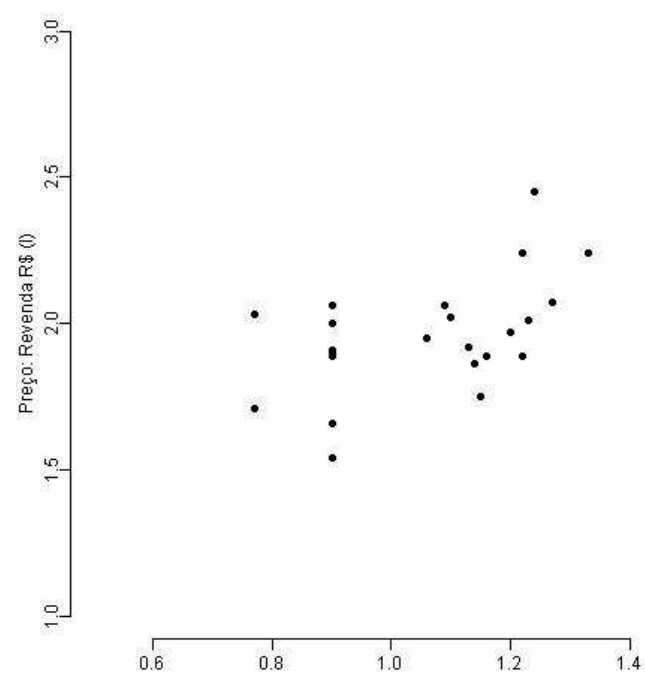

K-) Preço: produtor R\$ (l)

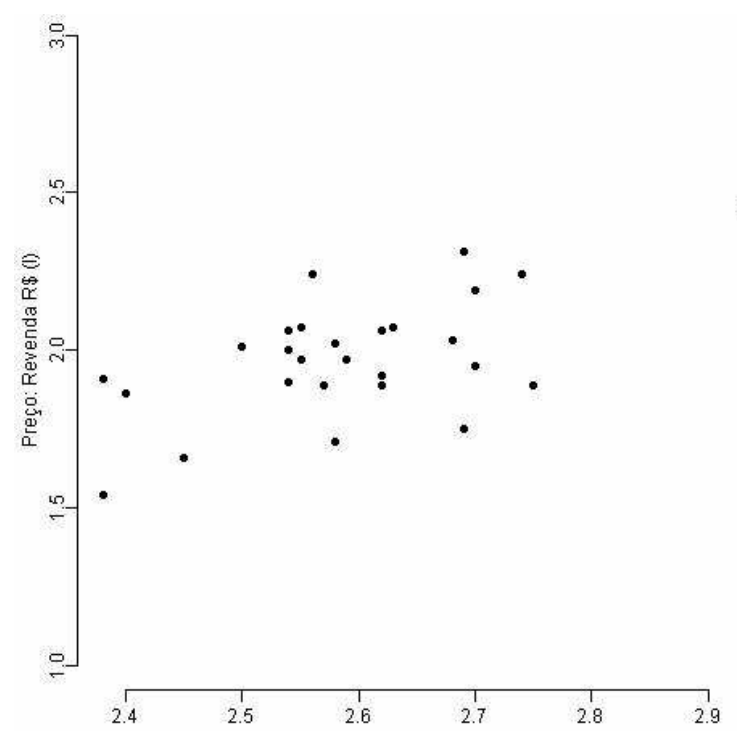

M-) Preço: gasolina C R $\mathbf{~ ( I ) ~}$

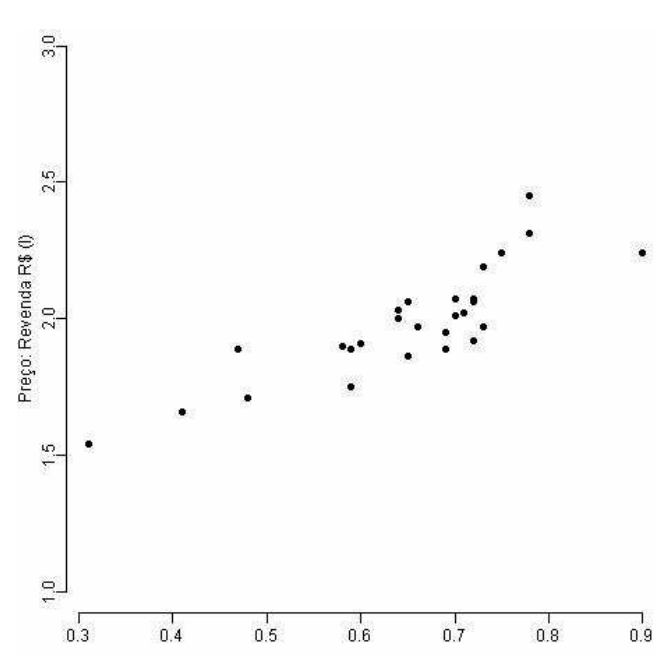

J-) Impostos sobre o preço final pago na bomba R\$ (1)

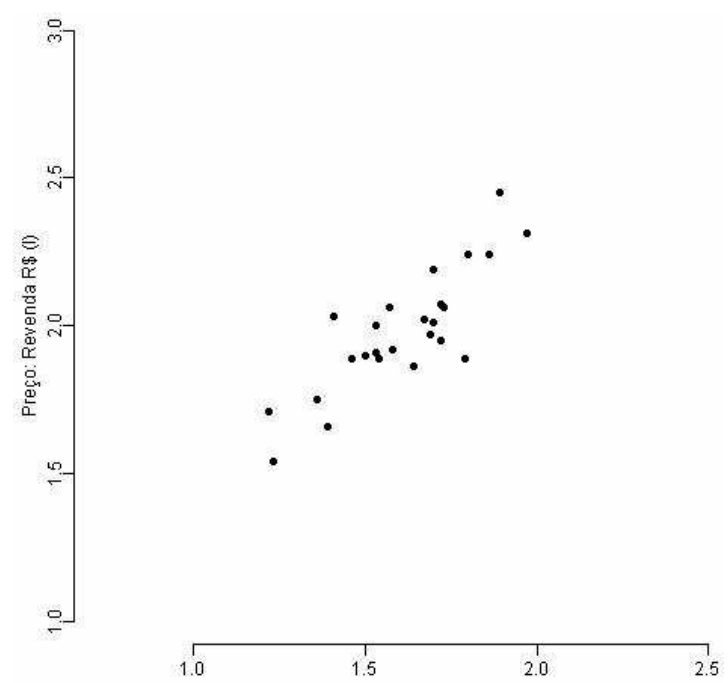

L-) Preço: distribuidora R (I)

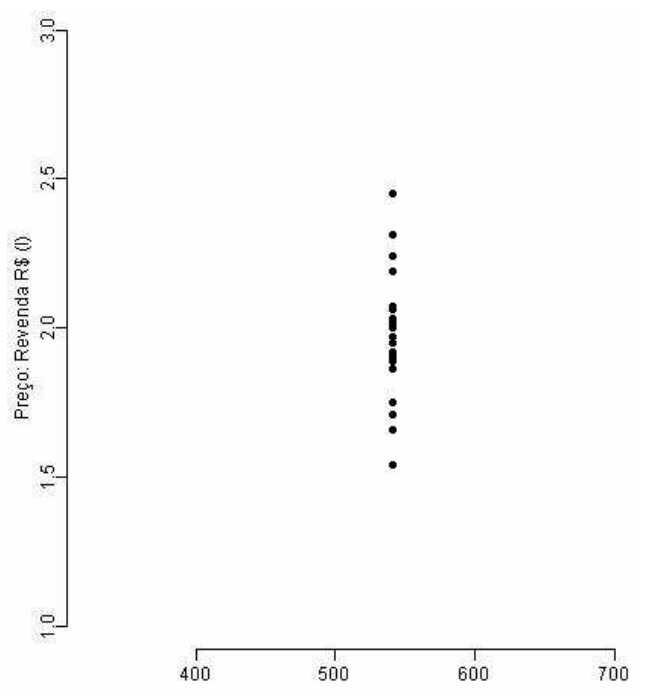

N-) Preço: açúcar exportação R \$ (t) 


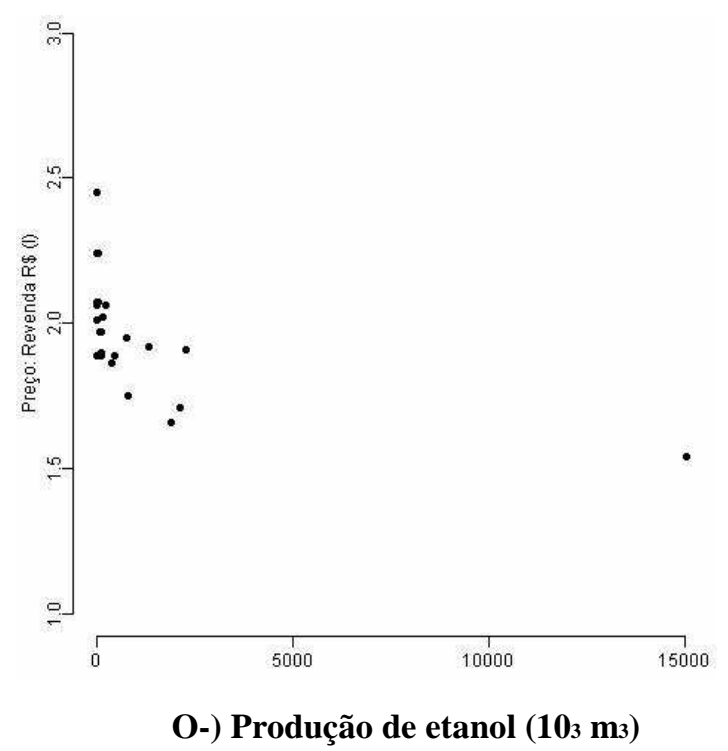

Gráficos 9A : 90 - Representações diversas da relação das variáveis versus preço de revenda

Os Gráficos de 9-A a 9-O apresentados possibilitaram avaliar apenas como os dados se comportam graficamente na relação preço de revenda e suas respectivas variáveis compreendidas, a seguir, como explicativas (independentes). Nestes, é possível observar preliminarmente que algumas variáveis não apresentam uma relação linear clara com a variável preço de revenda, como: capacidade nominal de armazenamento do etanol $\left(\mathrm{m}^{3}\right)$, produção de açúcar (t) e frota de carros movido a etanol e flex. Além da variável preço do açúcar tipo exportação $\mathrm{R}$ (t), que consta apenas de um valor praticado no território brasileiro, não sofrendo variações por região, cabendo, portanto, uma análise mais investigativa pela regressão linear múltipla.

\subsection{Resultados obtidos}

Todas as variáveis independentes foram analisadas entre si a fim de verificar se há uma forte correlação entre elas, a partir das respectivas análises do comportamento gráfico feito na seção anterior. Pela análise da regressão linear múltipla, permite-se dizer que foram encontradas correlações acima de 0,7 (correlação moderada à forte) entre algumas variáveis independentes; desta forma, o modelo de regressão pode ser prejudicado por um problema chamado multicolinearidade, que se caracteriza por uma variável independente ser também explicada por outra(s) variável(is) independente(s). 
Foi verificado no modelo de regressão linear completo por meio do uso da ferramenta SAS® 9.0/PROC REG, o valor dos fatores de inflação da variância (VIF), o qual mede o grau em que cada variável independente é explicada pelas demais variáveis independentes. Neste, é possível identificar que o maior VIF foi para a variável "Produção: Açúcar (t)" ou produção de açúcar em toneladas, levando-se em conta que esta apresentou correlações elevadas com outras 7 variáveis independentes. E, por ser interveniente, esta variável foi retirada do modelo.

Considerando o modelo sem a variável "Produção: Açúcar (t)" e verificando novamente o VIF, foi constatado que a variável " $\mathrm{N}^{\mathrm{o}}$ usinas de açúcar e etanol" também estava comprometendo os resultados do modelo. Calculando mais uma vez o VIF, a variável "Frota carros: etanol e flex" também foi retirada. E assim sucessivamente foram retiradas as variáveis " $\mathrm{N}^{\mathrm{o}}$ postos bandeira branca", " $\mathrm{N}^{\mathrm{o}}$ distribuidoras" e "Capacidade nominal de armazenamento do Etanol $\left(\mathrm{m}^{3}\right)$ ", até que os valores de VIF ficassem abaixo de 10. Segundo Hair et al (2005b), a análise da matriz de correlação permite identificar variáveis com correlação inferior a 0,9 , considerado o limite indicativo de colinearidade substancial. Ou seja, para se constituir o modelo, a partir da análise de multicolineraridade, desconsideraram-se as variáveis que inflacionavam a variância, dada sua forte correlação com a variável dependente, cabendo à análise qualitativa suas respectivas compreensões quanto a sua relação na formação de preços do etanol hidratado na revenda, o que acentua, portanto, sua complexidade.

Por conseguinte, obteve-se o seguinte modelo de regressão linear múltiplo, cuja variável dependente (também chamada de variável resposta) é "Preço: Revenda R \$ (l)", e as variáveis independentes (também chamadas de variáveis explicativas) são:
a) Preço: Distribuidora $\mathrm{R} \$(1)$
b) Preço: Produtor $\mathrm{R} \$(1)$
c) Preço: Gasolina C R \$ (1)
d) $\mathrm{N}^{\mathrm{o}}$ postos revendedores
e) Produção: Etanol (103 m3)
f) Frete $\mathrm{R} \$(1)$
g) Impostos sobre o preço final pago na bomba $\mathrm{R} \$(1)$
h) Custos: Produção Etanol Hidratado R\$ (1). 
O modelo final, com as respectivas estimativas, é dado por:

Preço: Revenda R \$ (l) = intercepto + 0,67408*preço pago na distribuidora $\mathrm{R} \$(\mathbf{l})+0,22045^{*}$ preço pago ao produtor $\mathrm{R} \$(\mathrm{l})+0,13882 *$ preço da gasolina $\mathrm{C} \mathrm{R} \$(\mathrm{l})+2,05 \mathrm{E}-05^{*} \mathrm{n}^{\mathrm{o}}$ postos revendedores 4,9E-06* produção de etanol hidratado $\left(10^{3} \mathrm{~m}^{3}\right)+1,32764 *$ frete $\mathrm{R} \$(\mathrm{l})+0,25953 *$ impostos sobre o preço final pago na bomba $\mathrm{R} \$(1)+0,41461^{*}$ custos de produção de etanol hidratado $\mathrm{R} \$(1)$

Notas:

a) Intercepto é o valor de Preço: Revenda $\mathrm{R} \$$ (1) quando todos os valores das covariáveis são iguais a 0 (zero).

b) 2,05E-05 (em notação científica), significa 0,0000205 .

\subsubsection{Discussão e análise dos dados obtidos: regressão linear múltipla}

Depois de concebido o modelo de regressão linear múltiplo, obteve-se o seguinte resultado:

Tabela 18 - Resultados da regressão linear múltipla (2009)

\begin{tabular}{|c|c|c|c|c|}
\hline \multirow{2}{*}{$\begin{array}{ll} & \text { Variáveis } \\
\text { Intercepto }\end{array}$} & \multirow{2}{*}{$\begin{array}{c}\text { Estimativas } \\
0,324\end{array}$} & \multirow{2}{*}{$\begin{array}{c}\text { P-valor } \\
0,33\end{array}$} & \multicolumn{2}{|c|}{$\begin{array}{c}\text { Intervalo de confiança } \\
95 \%\end{array}$} \\
\hline & & & $-0,36089$ & 1,00888 \\
\hline Preço: Distribuidora R \$ (1) & 0,67408 & $<0,01$ & 0,44007 & 0,90808 \\
\hline Preço: Produtor R \$ (1) & 0,22045 & 0,02 & $-0,56413$ & $-0,05677$ \\
\hline Preço: Gasolina C R \$ (1) & 0,13882 & 0,26 & $-0,11448$ & 0,39211 \\
\hline $\mathrm{N}^{\circ}$ postos revendedores & 0,00002048 & 0,38 & $-2,8 \mathrm{E}-05$ & $6,9 \mathrm{E}-05$ \\
\hline Produção: Etanol (103 m3 ) & $-0,00000491$ & 0,46 & $-1,9 \mathrm{E}-05$ & $9,03 \mathrm{E}-06$ \\
\hline Frete $\mathrm{R} \$(1)$ & 1,32764 & 0,15 & $-0,51844$ & 3,17373 \\
\hline Impostos sobre o preço final pago na bomba $\mathrm{R} \$$ (l) & 0,25953 & 0,17 & $-0,12539$ & 0,64445 \\
\hline Custos: Produção Etanol Hidratado R \$ (1) & 0,41461 & $<0,01$ & 0,22248 & 0,60674 \\
\hline
\end{tabular}

Para este modelo, o coeficiente de determinação (R2) obtido foi de 0,9706. Isso significa que 97\% da variabilidade dos seus dados estão sendo explicadas pelas covariáveis do modelo de regressão. O resultado do modelo também permite observar que todas as variáveis explicativas foram significativas para o modelo de regressão, pois apresentam p-valor abaixo de 0,05 .

Como o objetivo do trabalho é analisar a formação do preço de etanol hidratado no mercado brasileiro pela análise quantitativa, utilizando-se da regressão linear múltipla para descrever o quanto cada variável independente explica o preço de revenda do etanol (variável resposta), obtiveram-se, portanto, os resultados retratados na Tabela 18, os quais predizem que: 
a-) De acordo com a Tabela 18, pode-se concluir que o Preço: Distribuidora R\$ (1), Preço: Produtor R\$ (1) e Custos: Produção Etanol Hidratado R\$ (1) são fatores que influenciam a composição do preço de revenda do etanol, ao nível de significância de 0,05. As demais variáveis não apresentam contribuição significativa, porém podemos observar que a variável Frete $\mathrm{R} \$$ (l) tem uma estimativa muito alta, mas seu intervalo de confiança é amplo e, por isso, não apresenta significância, o que pode ter ocorrido devido ao tamanho amostral. A variável Frete seria mais viável significativamente ao modelo, se o número amostral fosse maior, o que permitiria diminuir a amplitude do intervalo de confiança e encontrar significância.

b-) Devido à relação linear existente entre as variáveis independentes com a variável resposta, é possível afirmar que, para cada unidade de aumento da variável independente, o preço do etanol se altera conforme as estimativas. Por exemplo, a cada real aumentado no preço do litro pela distribuidora, o preço de revenda aumenta em 0,67408, na presença de todos os fatores que compõem este modelo de regressão, ou seja, na presença de: Preço: Produtor R \$ (1), Preço: Gasolina C R \$ (1), No Postos Revendedores, Produção: Etanol (103 m³), Frete R\$ (1), Impostos sobre o Preço Final Pago na Bomba R\$ (1), Custos: Produção Etanol Hidratado R\$ (1). Outro exemplo: a cada real aumentado no preço do litro pelo Produtor, o preço de revenda aumenta em 0,22045 na presença de: Preço: Distribuidora R \$ (1), Preço: Gasolina C $\mathrm{R}$ \$ (1), $\mathrm{N}^{\mathrm{o}}$ postos revendedores, Produção: Etanol $\left(103 \mathrm{~m}^{3}\right)$, Frete R $\$(1)$, Impostos sobre o Preço Final Pago na Bomba R \$ (1), Custos: Produção Etanol Hidratado R \$ (1). E, assim sucessivamente para as demais variáveis que apresentam sua respectiva estimativa. Vale ressaltar que o valor de estimativa da variável Frete também é significativo, contribuindo e muito para a formação do preço; entretanto, seu nível de significância é alto, demonstrando o risco de assumir tal correlação.

\subsubsection{Discussão e análise dos dados obtidos: ANOVA com pós-teste de Tukey}

A ANOVA trouxe como resultado, conforme Tabela 19, a confiabilidade dos resultados obtidos. Nestes foram analisados as macrorregiões na relação preço da gasolina $\mathrm{C}$ versus preço do etanol hidratado, adotando-se o teste de análise de variância para amostras independentes (ANOVA) com o pós-teste de Tukey, por meio da ferramenta SAS® 9.0/PROC GLM. 
Tabela 19 - Resultados da Anova

\begin{tabular}{lccccc}
\hline Fonte de Variação & Graus de Liberdade & Soma de Quadrados & Quadrado Médio & Valor F & P-valor \\
\hline Modelo & 4 & 0,033 & 0,008 & 2,84 & 0,049 \\
Erro & 22 & 0,063 & 0,003 & & \\
\hline Total & 26 & 0,096 & & & \\
\hline
\end{tabular}

A Tabela 19 mostra que há diferença entre ao menos um par de regiões. Essa diferença entre os grupos encontra-se no p-valor, que foi de 0,049 (indica que 4,9\% é a probabilidade de se obter uma estatística de teste igual ou mais extrema quanto àquela observada em uma amostra, assumindo que a Ho possa ser verdadeira). Para verificar onde esta diferença ocorre, na Tabela 20, segue o pós-teste de Tukey.

Tabela 20 - Médias estimadas para cada região, pelo modelo de Anova (2009)

\begin{tabular}{lccc}
\hline & Região & Estimativa média & \multicolumn{2}{c}{ Intervalo de confiança 95\% } \\
& & 0,645 & 0,757 \\
Centro-Oeste & 0,701 & 0,729 & 0,803 \\
Nordeste & 0,766 & 0,768 & 0,853 \\
Norte & 0,810 & 0,689 & 0,800 \\
Sudeste & 0,745 & 0,695 & 0,824 \\
Sul & 0,760 & \\
\hline
\end{tabular}

Por meio das médias estimadas e seu respectivo intervalo de confiança, é possível fazer inferências e constatar que, em média no ano de 2009, nenhuma região apresentou-se mais vantajosa quanto ao abastecimento do etanol hidratado, considerando o limiar de 0,7. Isso porque todos os intervalos de confiança contêm este valor, ou estão acima dele. Em contrapartida, havia sido constatado no Capítulo 5 que as regiões Sudeste e Centro-Oeste apresentaram mais vantagens no abastecimento com o referido combustível; e por meio da análise obtida na Tabela 20, tal constatação pode ser plausível, pois ambas as regiões apresentaram as menores estimativas e o intervalo de confiança inferior aos 95\%. É possível também inferir que as regiões Norte e Nordeste são menos vantajosas, considerando o abastecimento com etanol; contudo, os seus respectivos intervalos de confiança são também inferiores aos $95 \%$. Daí a necessidade de se considerar o teste de Tukey. 
Tabela 21 - Pós-teste de Tukey

\begin{tabular}{lcccc}
\hline \multicolumn{1}{c}{ Região } & $\begin{array}{c}\text { Diferenças entre } \\
\text { médias }\end{array}$ & $\begin{array}{c}\text { Intervalo de confiança } \\
\text { simultâneo 95\% }\end{array}$ & Significância \\
\hline Norte - Nordeste & 0,04 & $-0,04$ & 0,13 & NS \\
Norte - Sul & 0,05 & $-0,06$ & 0,16 & NS \\
Norte - Sudeste & 0,07 & $-0,03$ & 0,17 & NS \\
Norte - Centro-Oeste & 0,11 & 0,01 & 0,21 & $* * *$ \\
\hline Nordeste - Norte & $-0,04$ & $-0,13$ & 0,04 & NS \\
Nordeste - Sul & 0,01 & $-0,10$ & 0,11 & NS \\
Nordeste - Sudeste & 0,02 & $-0,07$ & 0,12 & NS \\
Nordeste - Centro-Oeste & 0,06 & $-0,03$ & 0,16 & NS \\
\hline Sul - Norte & $-0,05$ & $-0,16$ & 0,06 & NS \\
Sul - Nordeste & $-0,01$ & $-0,11$ & 0,10 & NS \\
Sul - Sudeste & 0,02 & $-0,11$ & 0,14 & NS \\
Sul - Centro-Oeste & 0,06 & $-0,06$ & 0,18 & NS \\
\hline Sudeste - Norte & $-0,07$ & $-0,17$ & 0,03 & NS \\
Sudeste - Nordeste & $-0,02$ & $-0,12$ & 0,07 & NS \\
Sudeste - Sul & $-0,02$ & $-0,14$ & 0,11 & NS \\
Sudeste - Centro-Oeste & 0,04 & $-0,07$ & 0,16 & NS \\
\hline Centro-Oeste - Norte & $-0,11$ & $-0,21$ & $-0,01$ & $* * *$ \\
Centro-Oeste - Nordeste & $-0,06$ & $-0,16$ & 0,03 & NS \\
Centro-Oeste - Sul & $-0,06$ & $-0,18$ & 0,06 & NS \\
Centro-Oeste - Sudeste & $-0,04$ & $-0,16$ & 0,07 & NS \\
\hline
\end{tabular}

*** Comparação significativa ao nível de 0,05

NS Comparação não significativa ao nível de 0,05

De acordo com a Tabela 21, o pós-teste de Tukey mostra a existência das diferenças entre alguma região em relação à variável (preço do etanol/preço da gasolina). Verifica-se que houve evidências de diferença entre as regiões Norte e Centro Oeste, mostrando que é mais vantajoso abastecer com etanol hidratado na região Centro-Oeste que na região Norte, pois o valor da comparação (Norte - Centro-Oeste) tem uma estimativa média de 0,11 unidades a mais que a região Centro-Oeste, além de seu intervalo de confiança não conter o valor 0 (zero).

Como pode ser visto, o modelo de regressão linear múltiplo identificou-se eficaz, dado que seu coeficiente de determinação foi de $97 \%$. E dentre as 15 variáveis propostas para explicar a formação de preços do etanol hidratado no mercado brasileiro, constatou-se que 8 foram mantidas, e as outras 7 foram excluídas pela multicolinearidade. Portanto, as variáveis Preço: Distribuidora R\$ (1), Preço: Produtor R \$ (1) e Custos: Produção Etanol Hidratado R \$ (1) são fatores que influenciam a composição do preço de revenda do etanol, ao nível de significância de 0,05. As 5 demais variáveis (Preço: Gasolina C R\$ (1), $N^{\circ}$ postos revendedores, Produção: 
Etanol (103 m3), Frete R\$ (1) e Impostos sobre o preço final pago na bomba R \$ (1), não apresentam contribuição significativa. No entanto, é possível notar que a variável Frete R \$ (1) tem uma estimativa muito alta, mas seu intervalo de confiança é amplo e, por isso, não apresenta significância, isto pode ser decorrente do tamanho amostral.

Tal modelo, contudo, não é suficiente para análise da formação de preços do etanol no mercado interno, uma vez que já há complexidade ao desconsiderar dados dentre uma série histórica. A razão da limitação na análise quantitativa no levantamento de dados conduz à relevância de prevalecer a analítica da formação de preços também com base qualitativa. $\mathrm{Na}$ análise qualitativa, as variáveis que interferem nas grandezas de mercado, oferta e demanda permitem realizar inferências que sucedem inicialmente da disponibilidade da matéria-prima, cana-de-açúcar, e posteriormente da decisão sobre qual será seu uso (produzir açúcar ou etanol). No entanto, na análise quantitativa, o modelo não utilizou situações de incerteza e desconsiderou a variável interveniente produção de açúcar tipo exportação, uma vez que esta não possui parâmetros quantitativos por unidade de federação, mas que, por sua vez, é significativo, ao considerar em sua análise qualitativa que é produto decorrente da mesma matéria-prima, cana-de-açúcar.

Pela Anova, foi possível inferir vantagens de se abastecer a etanol hidratado no mercado interno. A constatação que se obteve foi da inviabilidade apresentada no ano de 2009 em se abastecer com o combustível etanol, salvo uma pequena exceção observada na região CentroOeste. Isso, sob análise qualitativa, pode ser decorrente da elevação da demanda pelo combustível, em razão da inserção do flex, como também de situações relacionadas à produtividade da cana-de-açúcar, por conta do uso do solo e clima, e/ou exportações de açúcar, que foi sob um recorde de 24.294.090 de toneladas, segundo dados da UNICA (2010). Pelo intervalo de confiança obtido na Tabela 20, observa-se que nenhum limite superior do intervalo está abaixo de 0,7, que é o limiar de vantagem em se abastecer com etanol; por isso, não se pode afirmar que uma região é sempre mais vantajosa que a outra. Mas, pode-se afirmar que, em média, a região Centro-Oeste apresenta mais vantagens no abastecimento com etanol, pois o limite superior do intervalo de confiança é o menor dentre as regiões. 


\section{CONTRIBUIÇÕES, CONSIDERAÇÕES E CONCLUSÕES}

\subsection{Contribuições}

Constatou-se, inicialmente, que, após a desregulamentação, houve uma nova configuração no setor do combustível etanol hidratado.

A presente pesquisa demonstrou a complexidade que há na formação de preços do etanol hidratado no mercado interno. Considerando apenas o método quantitativo, e isolando-se de inferências qualitativas, concluiu-se que parte das variáveis explicativas demonstradas na análise da regressão linear múltipla influenciou na composição do preço de revenda em 2009 de modo significativo, das quais: preço pago à distribuidora, preço pago ao produtor e custos de produção.

Em vista de uma análise estática comparativa, pelo método da Anova, em que se analisou a média dos preços do etanol no ano de 2009 nas macrorregiões, o estudo revelou que: a relação de preços dos combustíveis etanol hidratado/gasolina C comportou-se desfavorável ao abastecimento pelo combustível etanol hidratado no mercado interno. Isso se explica por fatores qualitativos que acentuam as grandezas de mercado no que compete à disponibilidade (oferta) da matéria-prima, cana-de-açúcar, e à dinâmica da demanda pelo combustível. Numa análise de cenário, percebe-se também que as oscilações dos preços são reflexos dos ajustes proporcionados pela produção de cana-de-açúcar e seu respectivo uso para fins de produção seja por açúcar ou etanol.

Outra contribuição significativa deu-se com a construção do modelo de regressão linear múltiplo, em que quinze variáveis atribuídas pela revisão de literatura acerca do mercado de etanol proporcionaram uma análise explicativa para formação de preços do etanol hidratado na revenda, das quais somente 3 variáveis se apresentaram significativas à formação de preços: preço pago à distribuidora, preço pago ao produtor e custos de produção. Ademais, o modelo também contribuiu para reforçar que, além dessas 3 variáveis significativas, existem outras que também possuem sua estimativa determinística na formação dos preços, como: impostos, produção de etanol hidratado, $\mathrm{n}^{\circ}$ postos revendedores e preço da gasolina C. Apesar de as outras variáveis também serem despertadas para o estudo quantitativo (preço do açúcar, frota, frete, armazenagem, $\mathrm{n}^{\circ}$ de postos de distribuidoras, $\mathrm{n}^{\circ}$ de revenda "bandeirada branca" e 
número de usinas de açúcar e etanol), estas não se comportaram estatisticamente significativas em sua relação linear por apresentarem multicolinearidade.

Foi verificado que os preços pagos à distribuidora possuem forte relação explicativa na formação dos preços do etanol hidratado. Estas são responsáveis exclusivamente por distribuírem os combustíveis na revenda, e constatou-se que no mercado do etanol hidratado aproximadamente $60 \%$ do abastecimento são feitos por distribuidoras que bandeiram os postos de revenda, e as demais são partilhadas por outras distribuidoras compreendidas como "bandeira branca". Observou-se que, nos contratos de exclusividades, os acordos de comercialização podem impactar nos preços em postos bandeirados, e em postos "bandeira branca" não existe contrato de exclusividade.

Explicar a formação de preços do etanol hidratado no mercado brasileiro é uma questão mais complexa do que algébrica ou contábil, como apontado pela revisão de literatura, segundo a qual o preço a ser praticado no mercado possa ser determinado pela empresa com base em seus custos e margens de lucratividade. Se determinado por condições mercadológicas ou econômicas, daí sua complexidade, por ser sugerido pelo mercado. Em relação a preços sugeridos pelo mercado, como abordagem teórica explicativa para a formação de preços, esse pressuposto teórico demonstrou ser aderente a esse estudo, uma vez que a dinâmica do mercado de combustíveis vincula-se sensivelmente à oferta e à demanda tanto da matériaprima quanto do etanol hidratado.

\subsection{Considerações}

Com relação às considerações trazidas neste trabalho, que atendem às questões específicas de investigação de estudo, tem-se:

a) As indústrias automobilísticas, com a tecnologia flex fuel, proporcionaram a elevação da demanda pelo combustível etanol hidratado desde que este apresentasse vantagem relativa a preços pagos pela gasolina C. Essa flexibilidade na escolha do combustível e a existência de incerteza com relação ao preço de etanol e da gasolina agregam valor ao automóvel, pois o consumidor pode escolher o combustível mais barato toda vez que abastecer o veículo. Entretanto, até que a frota de veículo proporcione essa autonomia que regule o mercado pelas forças do poder de decisão ao consumidor final, as oscilações de preços tendem a ocorrer 
dentre as regiões do país. Diante da complexidade assistida em arbitrar preços, considera-se que uma elevação no preço da gasolina $\mathrm{C}$ passa a proporcionar determinado grau de substituibilidade, por parte do consumidor final, pelo etanol hidratado; sendo assim, à medida que a frota de veículos flex fuel aumentar no Brasil, as relações entre os preços de etanol e da gasolina apresentarão características distintas das já encontradas, sejam estas de intensidade, duração ou direção do mercado de combustíveis.

b) Os preços nas macrorregiões em sua relação etanol hidratado e gasolina C, admitindo-se o limiar 0,7 referente ao desempenho econômico diferenciado pelo motor, revelaram que, em sua série histórica analisada num período de 10 anos (2001 a 2010), apenas na região Norte demonstrou-se vantajoso o uso da gasolina C. Em contrapartida, com uso da ferramenta estatística da análise da variância, apenas no ano de 2009, constatou-se que somente a região Centro-Oeste apresentou vantagem para o uso do etanol hidratado. Isso leva a inferir a relevância das variáveis qualitativas na análise, pois, ao relacionar os preços e compará-los entre as macrorregiões, traz a complexidade em afirmar que nenhuma vantagem há em se abastecer com etanol hidratado, exceto para a região Centro-Oeste. Isso ocorre pois se trata de um período no qual o país atingiu seu recorde na exportação do açúcar em 24 milhões de toneladas, a produtividade da cana-de-açúcar ficou aquém das expectativas por razões de solo e clima e a própria elevação da demanda, sobretudo na região Sudeste, onde não se apresentou sua esperada vantagem. Essas considerações qualitativas induzem a uma explicação para o comportamento dos preços e suas respectivas vantagens dentre as macrorregiões do país.

c) Nos postos de revenda, os preços do etanol hidratado são constituídos pelo ICMS que é recolhido, pelo preço de aquisição da distribuidora, no qual já estão inclusos os impostos recolhidos pelas usinas e destilarias, o PIS e a Confins, e sua respectiva margem de lucro. Estes são os principais gastos que oneram o preço final pago na bomba, os quais foram passíveis de serem caracterizados qualitativamente nesta tese. Porém, não coube como objetivo principal especificar que equação compõe os preços formados na revenda (tributo, preço da distribuidora e margem), mas compreendê-la dentre outras variáveis preditivas e complexas ao longo da cadeia. Outra constatação relevante é que, durante a fase de intervenção do governo no setor sucroenergético, os esforços se acentuavam na busca da credibilidade do consumidor final, promovendo esforços que resultavam em preços mais 
acessíveis; agora, com o veículo flex, a decisão do abastecimento é determinada pelo menor preço do combustível e unilateral ao consumidor final, tornando a credibilidade quanto à forma de criação ou destruição de valor a ser concebida pelas decisões do governo em incentivar o setor a expandir sua produção. A expansão da produção deve obedecer um timing certo com a estrutura do setor, como por exemplo: a capacidade de armazenagem.

d) Do ponto de vista da adição do etanol anidro à gasolina $\mathrm{A}$, tornando-a gasolina $\mathrm{C}$, ao teto de $25 \%$, o governo objetiva singularmente incentivar o setor sucroenergético, regular o estoque do etanol hidratado e diminuir as importações de barris de petróleo. No que compete ao estímulo da diminuição de preços do etanol hidratado por conta da flexibilização desse teto, considera-se que, para cada litro de gasolina C comercializado, há 1/5 de etanol anidro; e para converter etanol hidratado em anidro, a perda é em torno de 7\% de um combustível pelo outro. Assim, considerando os dados da ANP (2010), a comercialização de gasolina C em 2009 foi em torno de 25 bilhões de litros. Desse montante, o governo encomendou um volume de etanol anidro ao redor de 6,2 bilhões de litros. Se os 7\% da perda para fazer anidro fosse revertido para manter o mercado do etanol hidratado, o volume desse mercado ficaria em torno de 4,3 milhões de litros de etanol hidratado, mais os 6,2 bilhões, potencializando uma oferta de etanol hidratado em 6,6 bilhões de litros, que deixaram de ser consumidos nesse ano de 2009, para ser adicionado em forma de etanol anidro à gasolina C. Flexibilizar esse teto para $20 \%$ implicaria numa economia de 1,5 bilhões de litros a ser acrescidos para o mercado de etanol hidratado. Para um país que comercializou 26 bilhões de litros de etanol hidratado, essa economia não se apresenta significativamente para o setor de combustíveis, que se depara com um mercado que comporta uma quantidade de veículos movidos a etanol e flex em torno de 15 milhões. Outra consideração importante é quanto ao período da safra que estende de abril a novembro, e, nos meses da entressafra, há pouco bagaço de cana-de-açúcar para ser queimado e gerar energia elétrica e vapor (balanço térmico), para que se possa obter do etanol hidratado o etanol anidro. Como parte desse processo depende do bagaço, no período de entressafra, ocorre a sua diminuição, e isso implica na disponibilidade e custos para fornecimento do etanol anidro para as refinarias. Esse fato ocorre se houver contratos futuros de fornecimento a serem cumpridos com as refinarias, ocasião em que os custos no processo da fabricação do etanol anidro aumentam dada a limitação da queima do bagaço; e por ser período de entressafra, esse acordo futuro implica também na diminuição da oferta do etanol hidratado, incorrendo em preços maiores no mercado de combustíveis. 
e) Após as desregulamentações do mercado, o governo não mais exerce mecanismos diretos de intervir na formação de preços do etanol. As decisões de usos alternativos proporcionados pela cana-de-açúcar (entre produzir açúcar ou etanol) estão condicionadas para os produtores aos interesses mercadológicos, econômicos, momentâneos e estratégicos.

f) Com relação aos usos alternativos da cana-de-açúcar, as considerações pertinentes destacam-se no cenário que se constrói acerca dessa matéria-prima, em vista das tecnologias alternativas na produção de plástico e diesel a partir do etanol, prospectando uma conjuntura de demanda crescente e otimista para expansão produtiva da cana-de-açúcar, sem considerar a possibilidade da demanda se efetivar no mercado internacional.

g) Com relação à logística, compreende-se, com base na herança da fase do Proálcool, que o governo subsidiava os fretes e controlava o estoque a partir da determinação da produção por açúcar ou etanol, de modo que os preços majorados no mercado interno pudessem ser homogêneos; e, com a desregulamentação, o setor tem herdado fortes pressões não só com os custos logísticos, como também os tributos que oneram a cadeia e são repassados em forma de cascata para o consumidor final. Destacando-se, portanto, a coordenação entre os agentes do setor sucroenergético e a necessidade de um marco tributário específico para o etanol, respeitando as necessidades de equilíbrio fiscal e abastecimento do mercado interno.

h) Outro aspecto que emerge desta pesquisa diz respeito à existência dos preços médios do combustível etanol hidratado nos postos de revenda. Estes são fornecidos pela ANP, que utiliza terceiros para executá-lo, e vale-se de uma metodologia amostral e não relacional (separando postos bandeirados e "bandeira branca"). Considerando que há diferença na prática de preços de um posto bandeirado por um não bandeirado, logo, a média dos preços anunciados pela ANP deveria ser apresentada separadamente. Sabe-se que são $43 \%$ de postos "bandeira branca" dos 37 mil postos existentes no país, sendo que todos devem prestar informações de qualidade e quantidade comercializada à ANP, cabendo, de certa forma, a proposição de alterar a metodologia utilizada por abranger a população e segmentar as informações de preços por postos de revenda conforme sua bandeira. Do contrário, as inferências estatísticas são passíveis de discussão, se as médias já se apresentam discutíveis sob esse aspecto. 


\subsection{Conclusões}

Com relação ao objetivo geral da tese, qual seja o de analisar a formação de preços do combustível etanol hidratado no mercado brasileiro, tem-se que:

A análise quantitativa permitiu identificar que, apesar da complexidade existente ser expressiva por razões da oferta e demanda por etanol hidratado, os preços também são formados significativamente pelo comportamento dos preços pagos ao produtor e ao distribuidor, bem como por seu respectivo custo de produção nas usinas.

Essas três variáveis, identificadas no estudo como as principais variáveis explicativas na formação dos preços do etanol hidratado, atendem ao problema central proposto na presente pesquisa, porém não devem ser analisadas isoladamente na compreensão das oscilações de preços. Isso porque há outras variáveis com estimativa de relação linear menos significativas, e que contribui para explicar a formação de preços, como: impostos, produção de etanol hidratado, preço da gasolina $\mathrm{C}$ e $\mathrm{n}^{\mathrm{o}}$ de postos revendedores. Essas variáveis afetam os preços e realçam as razões das diferentes práticas de preços nas macrorregiões do mercado interno.

Ademais, a formação de preços também se constitui pelos aspectos qualitativos do mercado de etanol e que afetam a oferta e a demanda, tais como: diferenciação tributária do ICMS, fraudes, usos alternativos da matéria-prima cana-de-açúcar, regulamentos, expansão da produção, produtividade, solo e clima, sazonalidade e, até mesmo, interesses econômicos regionais.

Sob o ponto de vista qualitativo, conclui-se que a distribuição, desde a matéria-prima até o etanol hidratado, atribui relevância analítica quanto à capacidade de suprir o mercado, por se tratar da oferta, devendo haver mecanismos de comercialização claros entre os agentes. Nesse sentido, a necessidade de um mecanismo bem definido parte do desafio de se estabelecer um planejamento estratégico bem coordenado e integrado.

Ficou evidente que a prática dos preços diferenciados entre os postos de combustíveis, além das constatações quantitativas observadas no mercado, conta também com considerações qualitativas, pois a relação comercial estabelecida entre as distribuidoras e os revendedores, resulta em aspectos interessantes de análise da variação de preços, uma vez que, sendo revendedores bandeirados, há contratos de exclusividade no fornecimento do etanol hidratado 
firmado em longo prazo, ao passo que, em postos não bandeirados, há opções de aquisição entre distribuidoras mais vantajosas. Ambas competem entre si no mercado de combustíveis. Porém, o revendedor bandeirado, devido ao seu alto investimento no empreendimento para atender determinadas cláusulas contratuais e também pela relação comercial estabelecida com a distribuidora, tem seu preço pago pelo combustível majorado no momento do fornecimento, o qual é repassado ao consumidor final, ou seja, como o estoque é rotativo da usina à distribuidora e, em seguida, à revenda, qualquer que seja o preço tomado pela distribuidora esse imediatamente é repassado à revenda, com a qual tem sua relação comercial préestabelecida em fornecimento. Esse mecanismo comercial, que reflete em preços entre distribuidora e revenda, não é o mesmo ocorrido entre distribuidoras e revendas "bandeira branca". Apesar de as usinas e destilarias estabelecerem volume comercial significativo com as distribuidoras que empregam a bandeira na revenda, as demais distribuidoras tomam o mesmo preço repassado do produtor (usina ou destilaria), pois esta também tem sua negociação com os produtores no mercado spot.

Note-se que a variação do preço do etanol hidratado, sob o ponto de vista qualitativo de análise, é relevante para o estudo, e que, além dos mecanismos comerciais entre os agentes, há também que se enfatizar a fragilidade com que o setor se deparou no quesito tributação. Este desencadeou, pós-desregulamentação, uma série de fraudes, como: etanol molhado, quando se adiciona no etanol anidro água; vendas clandestinas entre usinas e revenda ou distribuidora sem nota fiscal; adição de etanol hidratado ou anidro acima dos $25 \%$ na gasolina A; descaminho da mercadoria com fins de beneficiar-se de Estados com alíquotas de ICMS que permitem créditos fiscais, sonegação de PIS e a Cofins por parte das distribuidoras; enfim, toda essa fraude detectada no setor mobilizou a alteração na coloração do anidro, para evitar o etanol molhado, bem como uma reestruturação tributária do setor, o que passou a onerar os tributos na fonte produtora (usinas e destilarias), por meio da Medida Provisória 413, segundo a qual ficam responsáveis pelo recolhimento de $100 \%$ dos tributos, repassados posteriormente em toda cadeia. Essa mudança na aplicação tributária busca evitar com que a informalidade afete a margem de lucro dentre os agentes que agem legalmente, visto que aqueles que atuavam de maneira ilegal conseguiam vender o etanol hidratado com preço reduzido. 


\subsubsection{Limitações e perspectivas futuras}

A abrangência desta pesquisa revela questões interessantes para fundamentar pesquisas futuras. Algumas questões são novas e outras devem confirmar a importância atribuída por outros pesquisadores em diversas áreas.

A primeira limitação deu-se no objeto da tese: formação de preços do etanol. Trata-se de um assunto denso e altamente complexo, pois não se limita apenas em analisar de forma algébrica ou contábil como o preço é constituído, sobretudo na revenda, cabendo, por conseguinte, uma análise mais apurada e dinâmica do mercado de etanol. O estudo limita-se em seu objeto de análise pelo aspecto temporal, sendo que o período analisado reflete o cenário do momento, uma vez que é possível se deparar com outras situações específicas do mercado de combustíveis, caso viabilizem no mercado inovações tecnológicas com motorização híbrida, por exemplo.

Observou-se, na fundamentação teórica, que a formação de preços na abordagem econômica prioriza as forças da demanda e da oferta, as quais convergem ao longo prazo para um determinado ponto de equilíbrio. Este, porém, deve ser assistido pelas condições mercadológicas de curto prazo, em que os preços devem ser sugeridos pelo mercado sob condições de competitividade e ganhos de eficiência produtiva. Nessa linha, a limitação do estudo demonstrou, para o caso específico do etanol hidratado, que situações de oferta e demanda se emparelham por condições mercadológicas, sobretudo no que compete à tecnologia, capaz de despertar tanto a demanda quanto a oferta, sendo que tal ajuste se reverte nas oscilações de preços. Essa linha teórica tênue ao segmento do etanol remete a uma análise mais dinâmica e prospectiva do mercado de combustíveis, que possibilite estudos de variáveis analíticas capazes de compreender não só as variáveis que formam seus preços, mas qual a sua tendência.

A tese depara-se com estudos no setor energético, e sua limitação deparou-se com a ausência dos esforços estratégicos do governo para atenuar as fortes oscilações nos preços do etanol hidratado. 
O modelo estatístico de regressão linear múltipla utilizado tem sua limitação, cabendo uma análise qualitativa mais refinada, sobretudo, quanto às condições mercadológicas impostas ao setor, as quais são altamente dinâmicas e prospectivas e impactam na oferta e demanda.

A utilização das médias dos meses para o ano base de análise de regressão linear (ano de 2009) representou um fator limitador de pesquisa, mas que teve de ser conduzido dessa forma visto que nem todas as variáveis continham valores mensais disponíveis.

Constatou-se, ainda, que o Brasil possui vantagens comparativas para produzir energias renováveis, sobretudo o etanol. Porém, não uma vantagem competitiva, uma vez que as oscilações dos preços no mercado interno são sensíveis à oferta e à demanda, perfazendo nesse aspecto um campo analítico a ser observado quanto à sua complementariedade.

O dilema da expansão da produção da cana-de-açúcar como barreira alimentar não foi aprofundado neste estudo. O que se sabe é que a expansão depende das condições de uso do solo, clima e tecnologia, estes permitem a geração de excedentes capazes de abastecer o mercado interno e alavancar a exportação; contudo, seus impactos sociais não foram investigados. A pesquisa deparou-se com a elevação da demanda pelo combustível etanol e pela necessidade de expandir a produção. Sob esse aspecto, propõe-se como fronteira para estudos futuros o entendimento da transferência da tecnologia desse segmento para outros países, com possibilidades de tornar o etanol uma commodity. A viabilidade ambiental e econômica do etanol hidratado já são consistentes para o mercado interno, mas limitada para alguns países; no entanto, expandir a produção no país que já possui maturidade produtiva, por ora, pode convergir como barreira alimentar.

Em relação à limitação metodológica, o maior problema é que não foram encontrados instrumentos de coleta de dados específicos para todas as variáveis em uma escala de tempo maior.

O que definiu a formação dos preços do etanol hidratado foram os preços pagos ao produtor e ao distribuidor, bem como os custos de produção de etanol hidratado. A análise limitou-se aos dados colhidos, e demonstrou não haver correlação fortemente significativa por parte dos impostos na formação dos preços do etanol. A variável impostos não foi significativa porque 
o p-valor é maior que 0,05 ; consequentemente, o intervalo de confiança contém o valor zero, e isso significa que a contribuição desta variável poder ser zero, ou seja, que sua contribuição pode ser nula, insignificante. Mas, no trabalho, apesar desta variável apresentar baixa correlação com a formação dos preços, essa já está compreendida nos custos de produção dos produtores, que recolhem seus tributos e repassam como custos para os demais atores da cadeia, até chegar à revenda.

Se os custos de produção foram constatados como uma das variáveis representativas na formação de preços, cabe inferir a seguinte sugestão para pesquisas futuras: tomando-se como base neste trabalho o levantamento de que os custos no fornecimento da cana-de-açúcar para a usina ou destilaria ser em torno de $60 \%$; deste percentual, é oportuno analisar os custos dessa matéria-prima para as usinas e destilarias; ou seja, como os custos da matéria-prima são constituídos: próprio (cana-de-açúcar é plantada pela usina ou destilaria), arrendado ou de terceiros, daí inferir quais fatores influenciam nesse percentual de $60 \%$.

Como as grandes distribuidoras são as que detêm as grandes marcas e possuem rede de postos com sua respectiva bandeira, e estão associadas ao Sindicom, cabe também investigar, como propósito de estudo futuro, sua relação comercial com os produtores (usinas e destilarias), já que os preços majorados para a revenda não sofrem tanta diferença. Isso porque os contratos existentes entre as distribuidoras e postos os revendedores são firmados por meio do contrato de venda mercantil de longo prazo de fornecimento do combustível, devendo a revenda em sua relação simplesmente repassar os preços ditados pelas distribuidoras no momento do fornecimento.

Por fim, esta pesquisa pode ser de interesse prático, por apresentar de forma mais ampla, porém não definitiva, possibilidades de se viabilizar esforços de um novo reordenamento do setor por tratar-se de energia e meio ambiente. 


\section{REFERÊNCIAS}

AAKER, D. A.; KUMAR, V.; DAY, G. S. Pesquisa de marketing. 2. ed. São Paulo: Atlas, 2004.

ANFAVEA - Associação Nacional dos Fabricantes de Veículos Automotores. 2010a. Disponível em: <http://www.anfavea.com.br>. Acesso em: 12/06/2010.

ANFAVEA - Associação Nacional dos Fabricantes de Veículos Automotores. Anuário da indústria automobilística brasileira 2010b. Disponível em: 〈http://www.anfavea.com.br〉. Acesso em: 24/05/2010.

ANP - Agência Nacional de Petróleo. 2010. Disponível em: <htpp://www.anp.gov.br>. Acesso em: 10/06/2010.

ANP - Agência Nacional de Petróleo. 2011. Disponível em: <htpp:// www.anp.gov.br>. Acesso em: 10/07/2011.

ALENCAR, E. Introdução à metodologia de pesquisa social. Lavras: UFLA/FAEPE, 2000. 105 p.

ALVES, A. J. O planejamento de pesquisas qualitativas em educação. Caderno de pesquisa, v. 77, p. 53-61, maio, 1991.

AMARAL, R. O. Análise da transação de suprimento de cana-de-açúcar e os relacionamentos inter-organizacionais. Ribeirão Preto, 2009. Dissertação (Mestrado em Administração de Organizações) - Programa de Pós-Graduação em Administração de Organizações, Faculdade de Economia, Administração e Contabilidade de Ribeirão Preto da Universidade de São Paulo.

ARAÚJO, S. S. Dimensionamento de Tancagem de Combustível em Bases Secundárias Decisões de Investimento para Superar Ineficiências do Sistema de Transporte Ferroviário. Rio de Janeiro, 2006. Dissertação (Mestrado em Engenharia Industrial) - Programa de PósGraduação em Engenharia Industrial, Pontifícia Universidade Católica do Rio de Janeiro.

BACIC, M. R. Gestão de custos: uma abordagem sob o enfoque do processo competitivo e da estratégia empresarial. Curitiba: Juruá, 2008.

BALLOU, R. H. Gerenciamento da cadeia de suprimentos: planejamento, organização e logística empresarial. 4. ed. Porto Alegre: Bookmann, 2001.

BERNARDI, L. A. Política e formação de preços: uma abordagem competitiva, sistêmica e integrada. 2. ed. São Paulo: Atlas, 1998.

BERNARDI, L. A. Manual de formação de preços: políticas, estratégias e fundamentos. 4. ed. São Paulo: Atlas, 2010.

BERNARDO NETO, O. Integração das principais tecnologias de obtenção de etanol através do processamento de celulose ( $2^{\mathrm{a}}$ geração) nas atuais usinas de processamento de 
cana-de-açucar (1 ${ }^{\text {a }}$ geração). São Paulo, 2009. Dissertação (Mestrado em Engenharia) Programa de Pós-Graduação em Engenharia, Escola Politécnica da Universidade de São Paulo.

BERNI, M. D.; BAJAY, S. V. Implicações energéticas e ambientais da eliminação das queimadas de canaviais. In: III Congresso Brasileiro de Planejamento Energético, Campinas. Anais..., v. 1, p. 1-5, 1998.

BESANKO, D.; DRANOVE, D.; SHANLEY, M. Economics of Strategy. New York: John Wiley \& Sons, Inc, 2000.

BESANKO, D.; BRAEUTIGAM, R. R. Microeconomia uma abordagem completa. Rio de Janeiro: LTC, 2004.

BEUREN, I. M.; ROEDEL, A. O uso do custeio baseado em atividades - ABC (Activity Based Costing) nas maiores empresas de Santa Catarina. Revista Contabilidade \& Finanças. São Paulo, n. 30, p. 7-8, set./dez. 2002.

BINGER, B. R.; HOFFMAN, E. Microeconomics with calculus. 2. ed. New York: AddisonWesley Educational Publishers Inc., 1998. 633 p.

BNDES - Banco Nacional de Desenvolvimento Econômico e Social. Bioetanol de cana-deaçúcar - energia para o desenvolvimento sustentável. Banco Nacional de Desenvolvimento Econômico e Social Report. Rio de Janeiro: BNDES, 2008.

BOMFIM, G. M. Gerenciamento de resultados - em cursos de pós graduação lato sensu através da metodologia do custeio alvo. São Paulo, 2006. Dissertação (Mestrado em Controladoria e Contabilidade) - Programa de Pós-Graduação em Controladoria e Contabilidade, Faculdade de Economia, Administração e Contabilidade da Universidade de São Paulo.

BOWERSOX, D. J.; CLOSS, D. J.; HELFERICH, O. K. Logistical management. 3. ed. New York: Macmillan, 2001.

BOSCO, F. Tecnologia verde e amarela. Petro \& Química, São Paulo, n. 307, 2008. Disponível em: <http://www.editoravalete.com.br/site_petroquimica/edicoes/ed_304/304.html>. Acesso em: 12/06/2010.

CAIXETA-FILHO, J.V. Etanol atrás de um “porto seguro”. 2008. Disponível em: <http://www.ideaonline.com.br/idea/ver.asp?id=381>. Acesso em: 15/07/2011.

CARMONA, P. H. G.; MARTINEZ, J. C.; SANTOS, L. C.; GORDONO, F. S. Evolução do processo de custeamento nas empresas: da controladoria às tomadas de decisão. XXVII ENEGEP, Out. 2007.

CASTRO, A. C.; KOSTER, C. H.; FRANIECK, E. K. Flexible Ethanol Otto Engine Management System. In III Congresso e Exposição Internacionais de Tecnologia da Mobilidade, SAE Brasil, São Paulo, 1994. 
CEPEA - Centro de Estudos Avançados em Economia. 2010. Disponível em: http://www.cepea.esalq.usp.br/. Acesso em: 13 jan. 2010

CHAMBERS, R. G. Applied production analysis: a dual approach. New York: Cambridge University Press, 1988. 331 p.

COELHO, F. S. Formação estratégica de precificação: como maximizar o resultado das empresas. 2. ed. São Paulo: Atlas, 2009.

COGAN, S. Custos e preços: formação e análise. São Paulo: Pioneira, 1999.

COMISSÃO EUROPEIA. Programa ALTENER. Bioenergia: Manual sobre tecnologias,projeto e instalação. Portugal, janeiro de 2004. 242 p.

CONAB - Companhia Nacional de Abastecimento. 2010. Disponível em:<http://www.conab.gov.br>. Acesso em: 17/07/2011.

CONAB - Companhia Nacional de Abastecimento. Perfil do setor do açúcar e do etanol no Brasil. 2008. Disponível em: 〈http://www.conab.gov.br/conaweb/download/safra/perfil.pdf $>$. Acesso em: 02/08/2010.

CONSECANA - Conselho dos Produtores de Cana-de-Açúcar, Açúcar e Álcool do Estado de São Paulo. 2010. Disponível em: < http://www.consecana.com.br/>. Acesso em: 04/09/2010.

COOPER, D. R.; SCHINDLER, P. S. Métodos de pesquisa em administração. Tradução: Luciana de Oliveira da Rocha. 7. ed. Porto Alegre: Bookman, 2003.

COPERSUCAR - Cooperativa de Produtores de Cana-de-Açúcar e Álcool do Estado São Paulo. 2003. A História do açúcar no Mundo. História do Açúcar no Brasil; Academia do Açúcar e do Álcool. Disponível em: <http:// www.copersucar.com.br>. Acesso em: 05/06/2010.

COSTA, C. C. Formação de preços de açúcar e álcool combustível anidro e hidratado no Estado de São Paulo. Piracicaba, 2001. Dissertação (Mestrado em Economia Aplicada) Programa de Pós-Graduação em Economia Aplicada, Escola Superior de Agricultura Luiz de Queiroz da Universidade de São Paulo.

DAVIDSON, S. et al. Accountanting: the language of business. 3. ed. New Jersey: Thomas Horton, 1977.

DIAS, A. L. Princípios básicos de importação. Rio de Janeiro: Confederação Nacional de Indústria, Departamento de Assistência à Média e Pequena Indústria, 1989.

DOLNIKOFF, F. Contratos de etanol carburante e a racionalidade econômica da relação entre usinas e distribuidoras de combustíveis no Brasil. São Paulo, 2008. Dissertação (Mestrado em Administração) - Programa de Pós-Graduação em Administração, Faculdade de Economia, Administração e Contabilidade da Universidade de São Paulo.

DRUCKER, P. F. The information executives truly need. Harvard Business Review Boston, v. 73, Iss. 1, p. 54, 1995. 
DUBOIS, A.; KULPA, L.; SOUZA, E. Gestão de custos e formação de preços: conceitos, modelos e instrumentos, abordagem do capital de giro e da margem de competitividade. 3. ed. São Paulo: Atlas, 2009.

DURÃES, F. O. M. Biocombustíveis: reais questões para a equação Brasil de desenvolvimento sustentável. Revista Política Agrícola. Ano XVII, n. 1, p. 130-134, Jan./Fev./Mar., 2008.

EPE - EMPRESA DE PESQUISA ENERGÉTICA. Balanço Energético Nacional 2009. Ano base 2008: Resultados Preliminares. Rio de Janeiro, 2009. Disponível em:

<https://ben.epe.gov.br/downloads/Resultados_Pre_BEN_2009.pdf>. Acesso em: 12/08/2009.

EROKHIN, V.; MAKHAN'KO, M.; SAMOILENKO, P. Fundamentals of thermodynamics and heat engineering. Moscow: Mir Publishers, 1986. 240 p.

FARINA, E. M. M. Q.; AZEVEDO, P. S.; SAES, M. S. M. Competitividade: Mercado, Estado e Organizações. São Paulo: Singular, 1997.

FARINA, E. et al. Mercado e concorrência do etanol. Etanol e Bioeletricidade A cana-deaçúcar no futuro da matriz energética. Coordenação e organização Eduardo L. Leão de Souza e Isaias de Carvalho Macedo. UNICA - União da Indústria de Cana-de-açúcar. São PauloSP, 2010.

FEIJÓ, F. T.; ALVIM, A. M. Impactos econômicos para o Brasil de um choque tecnológico na produção de etanol. ANPEC - Associação Nacional dos Centros de PósGraduação em Economia. 2008. Disponível em:

<http://www.anpec.org.br/encontro2008/artigos/200807210957440-.pdf>. Acesso em: 04/06/2010.

FERREL, O. C. et al. Estratégia de marketing. Sao Paulo: Atlas, 2000.

GALLAGHER, K. S.; HOLDREN, J. P.; SAGAR, A. D. Energy-Technology Innovation. International Affairs, John F. Kennedy School of Government, Harvard University, Cambridge, Massachusetts. First published online as a Review in Advance on august 25, 2006.

GARCIA, L. A. F. Economias de escala na produção de frangos de cortes no Brasil. Piracicaba, 2004. Tese (Doutorado em Economia Aplicada) - Programa de Pós-Graduação em Economia Aplicada, Escola Superior de Agricultura Luiz de Queiroz da Universidade de São Paulo

GATTI JUNIOR, W. A construção do conhecimento no processo de inovação: o desenvolvimento da tecnologia flex fuel nos sistemistas brasileiros. São Paulo, 2010. Dissertação (Mestrado em Administração) - Programa de Pós Graduação em Administração, Faculdade de Economia, Administração e Contabilidade da Universidade de São Paulo.

GHAURI, P. N.; GRONHAUG, K. Research methods in business studies: practical guide. New York: Prentice Hall, 1995.

GIL, A. C. Como elaborar projetos de pesquisa. 4. ed. São Paulo: Atlas, 2007. 
GODOY, A. S. Introdução à pesquisa qualitativa e suas possibilidades. Revista de Administração de Empresas - RAE. São Paulo, v. 35, n. 2, p. 57-63, mar.-abr. 1995.

GOLDENBERG, M. A arte de pesquisar: como fazer pesquisa em ciências sociais. 9. ed. Rio de Janeiro: Record, 2005.

GOLDEMBERG, J.; NIGRO, F. E. B.; SUANI, T. C. Bioenergia no estado de São Paulo: situação atual, perspectivas, barreiras e propostas. São Paulo: Imprensa Oficial do Estado de São Paulo, 2008. 152 p.

HAIR, J. et. al. Fundamentos de Métodos de Pesquisa em Administração. Porto Alegre: Bookman, 2005a.

HAIR, Jr., J. H.; ANDERSON, R. E.; TATHAM, R. L.; BLACK, W. C. Análise Multivariada de Dados. 5. ed. Porto Alegre: Bookman. 2005b.

HOGENDORN, J. S. O mercado na economia moderna: uma introdução à microeconomia. Rio de Janeiro: Zahar, 1975.

HORTA, N. L. A. Bioetanol de Cana-de-Açúcar: energia para o Desenvolvimento Sustentável. Organização BNDES e CGEE. Rio de Janeiro: BNDES, 2008.

IEA - The International Energy Agency, 2002. Energy Balances of Non-OECD Countries. Paris, 2001.

IMA - Institute of Management Accountants. Practices and techniques: cost management for logistics. Montvale. Statement Number 4-P, 1992.

KOJIMA, M.; MITCHELL, D.; WARD, W. Considering trade policies for liquid biofuels. Washington, DC: World Bank, 2007.

KATO, Y. Target costing support systems: lessons from leading Japanese companies. Management Accounting Research, n. 4, p. 33-47, 1993.

KOTLER, P. Administração de marketing. 5. ed. São Paulo: Atlas, 1998.

KOTLER, P.; KELLER, K. L. Administração de Marketing. 12. ed. Nova Iorque: Prentice Hall, 2005.

LAKATOS, E.; MARCONI, M. A. Fundamentos de metodologia científica. São Paulo: Atlas, 1991. $270 \mathrm{p}$.

LAKATOS, E.; MARCONI, M. A. Técnicas de pesquisa. São Paulo: Atlas, 1999.

LAKATOS, E.; MARCONI, M. A. Metodologia cientifica. 3. ed. São Paulo: Atlas, 2000.

LANZOTTI, C. R Uma análise energética de tendências do setor sucroenergético. Campinas, 2000. Dissertação (Mestrado em Engenharia Mecânica) - Programa de PósGraduação em Engenharia Mecânica, Faculdade de Engenharia Mecânica da Universidade de Campinas. 
LAMBERT, D. M.; STOCK, J. R.; VANTINE, J. G. Administração estratégica da logística. Tradução de Maria Cristina Vondrak. São Paulo: Vantine, 1998.

LEFTWICH, R. H. O sistema de preços e a colocação de recursos. Tradução de Evonir Batista de Oliveira. 3. ed. São Paulo: Pioneira, 1973.

LEPSCH, S. L. Precificação em Supermercado: um estudo exploratório junto a vinte empresas brasileiras. São Paulo, 1996. Dissertação (Mestrado em Administração) - Programa de Pós-Graduação em Administração, Faculdade de Economia, Administração e Contabilidade da Universidade de São Paulo.

LIMA, M. Custos logísticos: uma visão gerencial. Rio de Janeiro. 1999. Disponível em: <http://www.coppead.ufrj.br/pesquisa/cel/new/fr-sist-info.htm>. Acesso em: 08/2010.

LOPES, M. B. Análise dos canais de distribuição do etanol carburante brasileiro: um estudo exploratório. São Carlos, 2009. Dissertação (Engenharia de Produção) - Programa de Pós-Graduação em Engenharia de Produção, Departamento de Engenharia de Produção da Universidade Federal de São Carlos.

LUZ, O. S.; DE ROCCHI, C.A. Estrutura e funcionamento dos sistemas de apuração e análise de custos. Revista do Conselho Regional de Contabilidade do Rio Grande do Sul. Porto Alegre, v. 27, n. 93, p. 21-90, abr./jun. 1998.

MACEDO, I. C.; NOGUEIRA, L. A. H. Biocombustíveis. Cadernos NAE - Núcleo de Assuntos Estratégicos da Presidência da República, n. 2. Brasília: Secretaria de Comunicação de Governo e Gestão Estratégica, 2005. Disponível em: <http://www.planalto.gov.br/secom/nae/>. Acesso em: 08/07/2010.

MACHADO, P. R. M. Ésteres combustíveis em motor de ciclo diesel sob condições de pré-aquecimento. Santa Maria, 2008. Tese (Doutorado em Engenharia Agrícola) - Programa de Pós-Graduação em Engenharia Agrícola da Universidade Federal de Santa Maria.

MALhotra, N. K. Pesquisa de Marketing: uma orientação aplicada. Porto Alegre: Bookman, 2001.

MALIGO, C. Modelo para simulação da operação de carregamento de caminhões tanque em uma base de distribuição de combustíveis automotivos. Rio de Janeiro, 2005. Dissertação (Mestrado em Engenharia Industrial) - Pontifícia Universidade Católica do Rio de Janeiro.

MAPA - Ministério da Agricultura, Pecuária e Abastecimento. Plano Nacional de Agroenergia 2006-2011. Brasília-DF, 2005.

MAPA - Ministério da Agricultura, Pecuária e Abastecimento. Série Agronegócios. Cadeia Produtiva da Agroenergia. vol. 3. Coordenadores: Antonio Márcio Buainain e Mário Otávio Batalha, 2007.

MAPA - Ministério da Agricultura, Pecuária e Abastecimento. Os Biocombustíveis como nova Opção Energética. Palestra proferida na Reunião I do GT Bioenergia: Situação atual da bionergia e dos biocombustíveis. Brasília, 16 ago. 2007. Disponível em: 
http://www.cdes.gov.br/exec/documento/baixa_documento.php?p=f01200e46c415edf54cdf93 9e442ed652ad50cb9bcfa03e9f2cba4f1741b62820ec1d51cb20898c8659ae4f0fe36d70e9d06. Acesso em 18 abr. 2009.

MAPA - Ministério da Agricultura, Pecuária e Abastecimento. 2010. Disponível em: <http://www.agricultura.gov.br/>. Acesso em: 04/08/2010.

MARQUES, J. J. O “plástico verde” e o mercado brasileiro de etanol. São Paulo, 2010. Dissertação (Mestrado em Administração) - Programa de Pós-Graduação em Administração, Faculdade de Economia, Administração e Contabilidade da Universidade de São Paulo.

MARJOTTA-MAISTRO, M. C. Ajustes nos Mercados de Álcool e Gasolina no Processo de Desregulamentação. Piracicaba, 2002. Tese (Doutorado em Economia Aplicada) - Escola Superior de Agricultura Luiz de Queiroz da Universidade de São Paulo.

MARTINS, E. Contabilidade de Custos - Livro-Texto. 6. ed. São Paulo: Atlas, 1998. v. 1. $388 \mathrm{p}$.

MARTINS, E. Contabilidade de custos. 7. ed. São Paulo: Atlas, 2000.

MARTINS, E. Contabilidade de Custos. 8. ed. São Paulo: Atlas, 2001.

MARTINS, G. A. Manual para elaboração de monografias e dissertações. 2. ed. São Paulo: Atlas, 1994.

MATTAR, F. N. Pesquisa de marketing. São Paulo: Atlas, 2001

MELO, F. B. H. Preços dos Alimentos. Jornal O Estado de São Paulo - Suplemento Agrícola no 2457, São Paulo, p. G-2 - G-2, 11 dez. 2002.

MELO, F. H. de; FONSECA, E. G. da. Proálcool, Energia e Transportes - Pioneira, FIPE, São Paulo, 1981.

MELLO, F. O. T. As metamorfoses da rede de poder agroindustrial sucroalcooleira paulista: da regulação estatal para a desregulamentação. São Carlos, 2004. Dissertação (Mestrado em Engenharia de Produção) - Centro de Ciências Exatas e Tecnologia da Universidade Federal de São Carlos.

MELO, F. B. H. . Biocombustíveis e Preços de Alimentos. 2008. Palestrante, Universidade de Brasília - UnB. Impacto dos Biocombustíveis na Agricultura e na Indústria de Fertilizante do Brasil, promovido pelo Laboratório de Estudos do Futuro.

MONTORO FILHO, A. F. et al. Manual de economia. São Paulo: Saraiva, 1998.

MORAES, M. A. F. D. de. A Desregulamentação do Setor Sucroenergético do Brasil. Americana-SP: Caminho Editorial, 2000.

MOURA, C. C. A prática da pesquisa. São Paulo: McGraw-Hill do Brasil, 1978. 
NAGLE, T. T.; HOLDEN, R. K. Estratégia e táticas de preços: um guia para decisões lucrativas. São Paulo. Prentice Hall, 2003.

NARVER, J.; SLATER, S. The effect of market orientation on business profitability. Journal of Marketing, p. 20-35, Oct. 1990.

NASCIMENTO, P. S.; YU, A. S. O.; MARQUES, J. J.; MORILHAS, L. J.; CAMARGO JR, A. S. . The Ethanol Supply Challenges in Brazil. In: PICMET Conference 2010, 2010, Phuket, Thailand. PICMET 2010 Proceedings. Portland, Oregon, USA : PICMET - Portland International Center for Management of Engineering and Technology, 2010.

NASCIMENTO, P. S.; YU, A. S. O.; NIGRO, F. E. B.; QUINELLO, R.; RUSSO, R. F. S. M.; LIMA, N. C. The Case of Magneti Marelli Brazil: Endogenous and Exogenous Factors In Local Dominant Technology Development. In: PICMET Conference 2009, 2009, Portland, OR, USA. Proceedings of the PICMET 2009. Portland, OR, USA : PICMET - Portland International Center for the Management of Engineering and Technology, 2009a.

NASCIMENTO, P. S.; YU, A. S. O.; NIGRO, F. E. B.; FREDERICK, B. W. B.; PETHO, S. L.; MARQUES, J. J. . Competência compartilhada na determinação da trajetória tecnológica do sistema flex fuel: o caso da Delphi. In: XIII Seminário Latino Ibero-americano de gestión tecnológica, 2009, Cartagena de Indias, Colombia. Annales, 2009b.

NASSAR, A. M. et al. Prospects of the sugarcane expansion in Brazil: impacts on direct and indirect land use changes. In: Sugarcane Ethanol: Contributions to climate change mitigation and the environment. Wageningen Academic Publishers. The Netherlands, p. 6393, 2008.

NASTARI, P. Os atuais mercados consumidores e os mercados potenciais - parcerias e estratégias de negócio e a garantia de oferta. Seminário "O Brasil e a Energia do Século 21: açúcar e etanol”, dez./2004. Disponível em: <http://www.unica.com.br>. Acesso: 21/07/2010.

NEVES, M. F.; CONEJERO, M. A. Sistema agroindustrial da cana: cenários e agenda estratégica. Economia Aplicada, v. 11, n. 4, Ribeirão Preto-SP, 2007. Disponível em: <http://www.scielo.br/scielo.php?pid=S1413-80502007000400007\&script=sci_arttext.>.

Acesso em: 02/07/2010.

NEVES, M. F.; TROMBIN, V. G.; CONSOLI, M. A. Mapeamento e quantificação do setor sucroenergético. 2009. MARKESTRAT - Centro de Pesquisa e Projetos em Marketing e Estratégia . Disponível em: <http://www.favaneves.org/> Acesso em: 02/06/2010.

NETER, J.; WASSERMAN, W.; KUTNER, M. H. Applied Linear Statistical Models. 3. ed. Homewood, IL: Irwin. 1990.

NIGRO, F. E. B. Notas de aula da disciplina: Administração da Inovação em Produtos e Processos. São Paulo, Faculdade de Economia Administração e Contabilidade da Universidade de São Paulo - FEA/USP, 14/09/2009.

NOGUEIRA, L. A. H. Bioetanol de cana-de-açúcar: energia para o desenvolvimento sustentável. Organização BNDES (Banco Nacional de Desenvolvimento Econômico e Social) e CGEE (Centro de Gestão e Estudos Estratégicos). Rio de Janeiro : BNDES, 2008. 316 p. 
OICA - Organisation Internationale des Constructeurs d'Automobiles. Disponível em: <http://www.oica.net/> Acesso em: 10/11/2008.

OMETTO, A. Avaliação do Ciclo de vida do Álcool Etílico Hidratado Combustível pelos métodos EDIP, Exergia e Emergia. São Carlos, 2005. Tese (Doutorado em Engenharia) Programa de Pós-Graduação em Engenharia da Universidade de São Paulo

PARLETT, M.; HAMILTON, D. Evaluation as illumination: a new approach to the study of innovatory programs. In: GLASS, G. (coords.). Evaluation studies review annual, v. 1. Beverly Hills: Sage, 1976.

PAULILlO, L. F.; MELLO, F. O. T. de. Metamorfoses da rede de poder sucroalcooleira paulista e desafios para autogestão setorial. Agricultura em São Paulo, São Paulo, v.52, n.1, p. 41-62, jan./jun. 2005 .

PEFLEY, R. K. et al. A Feedback Controlled Fuel Injection System Can Accommmodate Any Alcohol-Gasoline Blend. Proceedings of the IV International Symposium on Alcohol Fuels Technology. Guarujá, SP, Brasil. 5-8 Oct., 1980.

PEREIRA, A. F. Ethanol, Employnebt abd Development: Lessons from Brazil. Geneva: International Labour Office, 1986.

PERES, C. R. G. Análise do método de custeio baseado em atividades aplicado à logística de distribuição. São Carlos, 2006. Dissertação (Mestrado em Engenharia) - Escola de Engenharia de São Carlos da Universidade de São Paulo

PEREZ JR., J. H.; OLIVEIRA, L. M.; COSTA, R. G. Gestão estratégica de custos. São Paulo, Atlas, 1999.

PEZZO, C. R.; AMARAL, A. N. do. O papel do Brasil no estabelecimento do mercado internacional de biocombustíveis. Revista USP, São Paulo, n. 75, p. 18-31, set./nov. 2007. Disponível em:

<http://www.revistasusp.sibi.usp.br/pdf/revusp/n75/03.pdf>. Acesso em: 22/08/2010.

PINDYCK, R. S.; RUBINFELD, D. L. Microeconomia. São Paulo: Makron Books, 1994. $968 \mathrm{p}$.

PRADO, E. F. S. Formação de Preços como Processo Complexo. Revista Estudos Econômicos. São Paulo, v. 37, n. 4, p. 745-769, out.-dez. 2007.

REVISTA IDEANEWS. Número 55. 2005. Disponível em: <http://www.ideaonline.com.br>. Acesso em: 05/07/2010.

RICHARDSON, R. J. et al. Pesquisa social: métodos e técnicas, 3. ed. São Paulo: Atlas, 1999.

ROMM, J. The car and fuel of the future. Energy Policy. Arlington, USA: Center for Energy and Climate Solutions, n. 34, p. 2609-2614, 2006. 
SANTOS, A. M. M. M.; BURITY, P. BNDES: 50 anos - Histórias Setoriais: O Complexo Automotivo. 2002. Disponível em: <htpp://www.bndes.gov.br>. Acesso em: 14/06/2010.

SAnTOS, M. H. de C. Política e Políticas de uma energia alternativa: o caso do Proálcool. Rio de Janeiro: Notrya, 1993.

SANTOS, R. V. dos. Modelo de decisão para gestão de preço de venda. São Paulo, 1995. Dissertação (Mestrado em Administração) - Programa de Pós-Graduação em Administração, Faculdade de Economia, Administração e Contabilidade da Universidade de São Paulo.

SÃO PAULO. Lei $\mathrm{n}^{\circ} 11.241$, de 19 de setembro de 2002. Dispõe sobre a eliminação gradativa da queima da palha da cana-de-açúcar e dá providências correlatas.

Disponível em: <http://www.cetesb.sp.gov.br/licenciamentoo/legislacao/estadual/leis/2002_ Lei_Est_11241.p df >. Acesso em: 20/10/2010.

SARDINHA, J. C. Formação de preço: a arte do negócio. São Paulo: Makron Books, 1995.

SARTORI, E. Gestão de preços. São Paulo: Atlas, 2004.

SAS Institute Inc. SAS/STAT® User's Guide. Version 9.0. Cary, NC: SAS Institute Inc. 1999.

SCANDIFFIO, M. I. G. Análise prospectiva do álcool combustível no Brasil - cenários de 2004 a 2024. Campinas, 2005. Tese (Doutorado em Planejamento de Sistemas Energéticos) Faculdade de Engenharia Mecânica da Universidade Estadual de Campinas.

SEABRA, J. E. A. Avaliação técnico-econômica de opções para o proveitamento integral da biomassa de cana no Brasil. Campinas, 2008. Tese (Doutorado em Engenharia Mecânica) - Programa de Pós Graduação em Engenharia Mecânica, Faculdade de Engenharia Mecânica da Universidade Estadual de Campinas.

SELLTIZ, C. et al. Métodos de Pesquisa nas Relações Sociais. São Paulo: Pedagógica e Universitária, 1974.

SILVA, A. T. B. da. Cenários do futuro e capacidades dinâmicas: um estudo do setor de etanol. São Paulo, 2010. Dissertação (Mestrado em Administração) - Programa de PósGraduação em Administração, Faculdade de Economia, Administração e Contabilidade da Universidade de São Paulo.

SINCOPETRO - Sindicato do Comércio Varejista de Derivados de Petróleo do Estado de São Paulo. 2010. Disponível em: <http://www.sincopetro.org.br>. Acesso em: 04/09/2010.

SINDICOM - Sindicato Nacional das Empresas Distribuidoras de Combustíveis e de Lubrificantes. 2010. Disponível em: <http://www.sindicom.com.br>. Acesso em: 08/09/2010.

SOARES, A. C.; LEAL, J. E.; AZEVEDO, I. R. de. Diagnóstico e modelagem da rede de derivados de petróleo no Brasil e sua representação em um SIG. In: XXIII Encontro Nacional de Engenharia de Produção, 2003, Ouro Preto, 2003. 
SOBRAL, M. C. et al. Flex fuel Technology - A Brazilian Innovation. In: 14th International Conference on Management of Technology, Viena, 2005.

SOUZA, R. R. Panorama, oportunidades e desafios para o mercado mundial de álcool automotivo. Rio de Janeiro, 2006. Dissertação (Mestrado em Planejamento Energético) Coordenação dos Programas de pós-graduação de Engenharia - COPPE, Universidade

Federal do Rio de Janeiro.

SOUZA, A.; CLEMENTE, A. Gestão de custos: aplicações operacionais e estratégicas. São Paulo: Atlas, 2007.

SZMRECSÁNYI, T. O Planejamento da Agroindústria Canavieira do Brasil (19301975). Universidade Estadual de Campinas. São Paulo: Hucitec, 1979.

TEIXEIRA, E. C. O desenvolvimento da tecnologia flex fuel no Brasil. Instituto DNA Brasil. 2005.

THOMPSON JUNIOR, A. A.; FORMBY, J. P. Microeconomia da firma: teoria e prática. 6. ed. Rio de Janeiro: Prentice-Hall do Brasil, 1998.

TRIVIÑOS, A. N. S. Introdução à Pesquisa em Ciências Sociais: a Pesquisa Qualitativa em Educação. São Paulo: Atlas, 1987. 175 p.

UNICA - União da Indústria de Cana-de-açúcar. 2010. Disponível em: <http://www.unica.com.br/>. Acesso em: 01/04/2010.

UNCTAD - United Nations Conference on Trade and Development - Conferência das Nações Unidas sobre Comércio e Desenvolvimento. Capital, accumulation, growth and structural change. Trade and Development Report. New York, 2003.

URDAN, F. T. Gestão do Composto de Marketing. São Paulo: Atlas. 2006.

VALDÉS, M. A. B. Um método para avaliar os aspectos ambientais da produção de álcool combustível e o conceito de eficiência ambiental. Campinas, 2000. Tese (Doutorado em Engenharia Mecânica) - Faculdade de Engenharia Mecância na Universidade de Campinas.

VAN GERPEN, J.; KNOTHE, G. Produção de biodiesel. In: KNOTHE, G. (Org.); VAN GERPEN, J.; KRAHL, J. Manual de Biodiesel. Tradução: Luiz Pereira Ramos. São Paulo: E Blücher, 2006. p. 29-45.

VIAN, C. E. F. Inércia e Mudanças Institucional: Estratégias Competitivas do Complexo Agroindustrial Canavieiro no Centro-Sul do Brasil. Campinas, 2002. Tese (Doutorado em Economia) - Instituto de Economia da Universidade Estadual de Campinas.

VIEGAS, H. A. Especificação de um ambiente para gestão de custos. São Paulo, 1986. Dissertação (Mestrado em Engenharia Mecânica) - Pós-Graduação da Faculdade de Engenharia Mecânica da Universidade Estadual de Campinas. 
WAACK, Roberto Silva; NEVES, Marcos Fava. Competitividade do sistema agroindustrial da cana-de-açúcar. São Paulo: PENSA/FIA/FEA/USP, 1998. 5 v.

XAVIER, C. E. O. Localização de tanques de armazenagem de álcool combustível no Brasil: aplicação de um modelo matemático de otimização. Piracicaba, 2008. Dissertação (Mestrado em Economia Aplicada) - Escola Superior de Agricultura Luiz de Queiroz da Universidade de São Paulo.

ZANÃO, A. G. Caracterização da infra-estrutura de armazenagem de álcool no Brasil e análise da sua concentração na região Centro-Sul. Piracicaba, 2009. Dissertação (Mestrado em Economia Aplicada) - Escola Superior de Agricultura Luiz de Queiroz da Universidade de São Paulo. 